\title{
Problematizacija svjedočenja u povijesnim romanima Feđe Šehovića
}

\section{Mikšić Labura, Dijana}

Doctoral thesis / Disertacija

2020

Degree Grantor / Ustanova koja je dodijelila akademski / stručni stupanj: University of Zagreb, University of Zagreb, Faculty of Humanities and Social Sciences / Sveučilište u Zagrebu, Filozofski fakultet

https://doi.org/10.17234/diss.2020.7636

Permanent link / Trajna poveznica: https://urn.nsk.hr/urn:nbn:hr:131:647785

Rights / Prava: In copyright/Zaštićeno autorskim pravom.

Download date / Datum preuzimanja: 2023-04-26

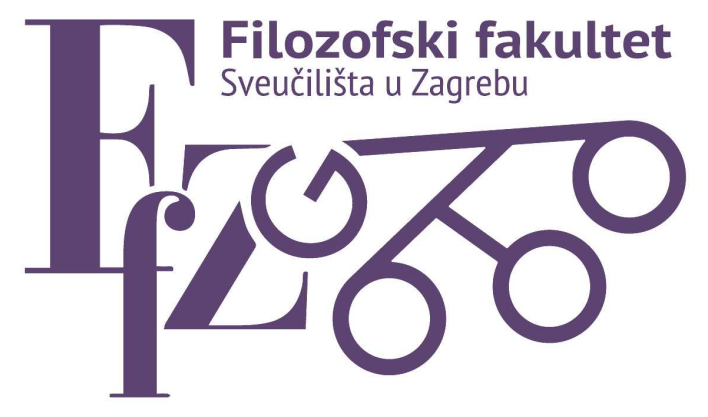

Repository / Repozitorij:

ODRAZ - open repository of the University of Zagreb Faculty of Humanities and Social Sciences
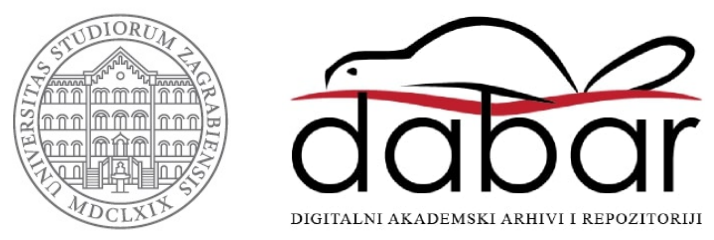
Filozofski fakultet

Dijana Mikšić Labura

\title{
PROBLEMATIZACIJA SVJEDOČENJA U POVIJESNIM ROMANIMA FEĐE ŠEHOVIĆA
}

\author{
DOKTORSKI RAD
}

Mentorica: dr. sc. Julijana Matanović, izv. prof.

Zagreb, 2020. 


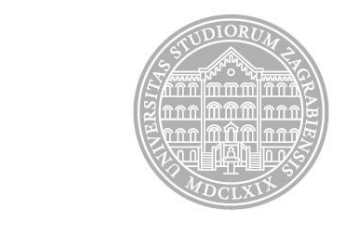

University of Zagreb

Faculty of Humanities and Social Sciences

Dijana Mikšić Labura

\title{
PROBLEMATIZATION OF TESTIMONY IN FEĐA ŠEHOVIĆ'S HISTORICAL NOVELS
}

\author{
DOCTORAL THESIS
}

Supervisor: dr. sc. Julijana Matanović, izv. prof.

Zagreb, 2020. 


\section{ŽIVOTOPIS MENTORICE}

Julijana Matanović rođena je 6. travnja 1959. godine u Gradačcu (Bosna i Hercegovina). Od 1962. godine živi u Hrvatskoj.

Osnovnu školu završila je u Đurđenovcu, a gimnaziju u Našicama.

Diplomirala je jugoslavenske jezike i književnost na Pedagoškom fakultetu u Osijeku, gdje je jedno vrijeme radila kao asistentica na predmetu Starija hrvatska književnost.

Na Filozofskom fakultetu Sveučilišta u Zagrebu pod mentorstvom prof. dr. Zorana Kravara magistrirala je 1989. na temi „Primarna i sekundarna generička obilježja u Đurđevićevim Uzdasima Mandalijene pokornice te doktorirala 1998. godine obranivši temu „Hrvatski povijesni roman XX. stoljeća“.

Od 1993. godine zaposlenica je Filozofskog fakulteta Sveučilišta u Zagrebu, na kojem od 2007. do prijevremene mirovine 2018. radi kao izvanredna profesorica na Katedri za noviju hrvatsku književnost.

Od 2014. godine je članica-suradnica HAZU-a.

Objavila je više od tristo znanstvenih rasprava, izvornih članaka, ogleda i književnih kritika, sudjelovala na četrdesetak kongresa, simpozija i okruglih stolova te bila suradnica u nizu projekata (Enciklopedija hrvatske književnosti, Stoljeća hrvatske književnosti, Leksikon hrvatskih pisaca, Hrvatska književna enciklopedija itd.).

Djelovala je kao urednica književnih časopisa (Quorum, Književna revija) i biblioteka (Quorum, Hit), recenzentica suvremenih proznih djela i članica prosudbenih povjerenstava za književne nagrade („Ksaver Šandor Gjalski“, V.B.Z.-ova nagrada, „Vladimir Nazor“, „Meša Selimovićc....).

Osim što se na književnome području istaknula kao znanstvenica i kritičarka, posebice na temi povijesnoga romana (npr. knjige Krsto i Lucijan i sumnja.strah@povijest.hr), Julijana Matanović autorica je brojnih beletrističkih proznih djela (Zašto sam vam lagala, Bilješka o piscu, Tko se boji lika još, I na početku i na kraju bijaše kava...).

Dobitnica je niza nagrada za književni i kritičarski rad (,,7 sekretara SKOJ-a“, ,Josip i Ivan Kozarac“, „Julije Benešić“, „Kiklop“, „Anto Gardaš“, „Mali princ“, „Ksaver Šandor Gjalski“").

Proza joj je prevođena na mnoge europske jezike. 


\section{SAŽETAK}

Polazeći od hipoteze kako u kontekstu korpusa suvremenoga hrvatskoga povijesnog romana Feđa Šehović (1930.) zauzima mjesto autora koji najdosljednije koristi testimonijalni diskurs u svrhu romaneskne izgradnje odnosa prema prošlosti, zbog čega se upravo testimonijalna pozicija nameće kao analitičko-interpretacijsko polazište, disertacijom se nastojalo problematizirati svjedočenje u povijesnim romanima ovoga književnika.

Metodološki okvir predstavljaju studije o žanrovskim obilježjima hrvatskoga povijesnog romana, naratološki instrumentarij, teorija intertekstualnosti i teorija kulturnoga pamćenja, $u$ čiju sferu spadaju i postavke o (ne)mogućnosti svjedočenju traume te problematika konstruiranja kolektivnih identitetnih predodžbi (imagološka vizura) putem svjedočenja. Koncept svjedočenja Šehović je zahvatio raznovrsnim narativnim strategijama, osiguravši figuri svjedoka različit status u narativu (svjedoci koji jesu/nisu likovi), kao i različitu pripovjednu i fokalizacijsku poziciju.

Svi protagonisti analiziranih Šehovićevih romana reprezentanti su tzv. povijesno slabih subjekata kojima pozicija svjedoka i akt svjedočenja predstavljaju mogućnost upisivanja u povijest. I primarni i sekundarni svjedoci pri tome nastupaju kao moralni svjedoci koji modelom pharmakosa / žrtvenoga jarca upućuju na besmisao ideološke žrtvenosti.

Diskurzivno raznoliki testimonijalni dokumenti inkorporirani su u romanesknu strukturu prvenstveno pozivanjem na zapise u okviru osnovnoga teksta, ali i fusnotama, predgovornom bilješkom te slučajem romana koji u cijelosti predstavlja zbir(ku) dokumenata.

Zapisi svjedoka u službi su postavke o tekstualno proizvedenoj prošlosti, kontinuirano razotkrivaju svoju intertekstualnu narav te odmiču fokus s odnosa zbilja - tekst na odnos tekst - tekst.

Testimonijalni diskurs u povijesnim romanima Feđe Šehovića funkcionira kao modus podrivanja ideološke vizure povijesnoga, pri čemu su preokupacije konstativima ustupile mjesto performativnoj moći samog testimonijalnog čina, a povijesna faktografija zamijenjena je razinom individualnoga iskustva povijesnoga.

\section{Ključne riječi}

Feđa Šehović, hrvatski (novo)povijesni roman, svjedočenje, svjedok, dokument, intertekstualnost, trauma, identitetne predodžbe 


\section{EXTENDED SUMMARY}

\section{Key words}

Feđa Šehović, Croatian (new) historical novel, testimony, witness, document, Intertextuality, trauma, identity imagery

Historical novels by contemporary Croatian writer Feđa Šehović (1930.) are only sporadically, and thus not sufficiently systematically, captured in Croatian literary science. Primarily with his attitude towards history (history as cyclicality, returning of same instead of history as a teacher of life), but also with many "building elements" (Matanović), Šehović is placed in the group of those authors of Croatian historical novels (Nedjeljko Fabrio, Ivan Aralica, Stjepan Tomaš, Ivan Supek, Ivica Ivanac, Ludwig Bauer ...), marked by a shift from the traditional historical novel, or the Šenoesque type novel. For some literary scholars (Milanja, Matanović), such a paradigm shift is marked by the terminological determinant of the Croatian new historical novel.

Guided by the hypothesis that within the genre of the Croatian historical novel, the act of testimony can be registered as a recognizable poetic designation of the work of Feđa Šehović, which is why the testimonial position is imposed as an analytical and interpretative starting point, the dissertation was focused on the problematization of testimony in the historical novels of this writer.

The analysis included a corpus of those Šehović novels that can be narrowly referred to as the historical novel genre: the "Dubrovnik trilogy" written under the pseudonym Raul Mitrovich (Gorak okus duše, 1983.; Oslobađanje đavola: Kronika, 1986.; Uvod u tvrđavu: Biblija za nevjernike, 1989.), Ilijasbegović's five books: Cronica travuniana from 2002. (1. Ilijas-beg, kapetan trebinjski; 2. Inšallah; 3. Begovina; 4. Dubrovački intermezzo; 5. Od Mostara do Haaga) and Prokleta ergela (2009.).

The concept of testimony in mentioned historical novels of Feđa Šehović is mostly discussed on the interplay of typology and position problem of both witnesses and documents, while the final chapters of the paper emphasize the constellation of testimony and memory / remembering (presentation of trauma by testimony, testimony in the service of identity representation).

The methodological framework is represented by studies on the genre characteristics of the Croatian historical novel, narratological instrumentation, intertextuality theory and cultural 
memory theory, in whose sphere are included settings about (im)possibility of witnessing trauma and the problems of constructing collective identity representations (imagological vision) through testimony.

Although based on a narrative model, testimony is irreducible only to the problem of storytelling (Felman, Derrida), it is inseparable from the categories of responsibility and obligation (Felman) and trust (Derrida). Namely, the witness's speech is always appellate, it is addressed to a certain addressee, who in turn becomes a further witness through a testimonial act, thereby realizing a potentially infinite testimonial chain.

In the framework of the theory of speech acts (J. L. Austin), testimony escapes the idea of constatives, in terms of establishing the (in) truthfulness of a testimonial statement. After all, the focus of the testimony is absolutely singular (Derrida), and thus objectively unverifiable. Testimony functions as a performative act — an act by which it acts - whereby the testimony is built on the interaction of its expositive and commissural component. The more visible representation of the mechanism of testimony in modern times may be related to a different attitude of history (in terms of historiography), but also of historical novels toward historiographic material, and thus to the past in general.

Although the contemporary Croatian historical novel, including those of Šehović, did not play with history as foreign authors of postmodernist historical novels did, in Croatian literature one cannot but register a different relation to the historical document as an unquestionable authority - this relationship is now based on reevaluation and doubt.

Testimonial discourse in the historical novels of Feđa Šehović primarily functions as a mode of undermining the ideological vision of the historical, whereby preoccupations with constituents gave way to the performative power of the testimonial act itself, and historical factography replaced by the level of individual experience of the historical.

The protagonists of recent Croatian historical novels mostly represent historically nameless / insignificant individuals, those who are not actors but victims in the trappings of historical rotation. The only privileged place in talking about historical can be achieved by such individuals as witnesses. Such a position enables them to bring (and) their own (historical) story through their testimonial statement to their addressee, ie the community to which the appeal was addressed.

Given the status of the witness figure in the narrative, it can be observed that most of the witnesses have the role of characters, both main / protagonists and side characters. 
With the dominance of witness-characters, witnesses who do not have the status of a romanesque character since they do not participate in the fabric flow, have found a place, albeit rarely, in the historical novels of Feđa Šehović.

The narrative position of testimony in the Gorak okus duše, Oslobađanje đavola, Prokleta ergela, and most of the Ilijasbegovići five books, that is, most of Šehović's historical novels, is realized by the situation of summoning a Genettian extradiegetic-heterodiegetic narrator on testimony. Only a small number of Šehović's novels gave the witness the narrative status. Thus, witnesses appear as homodiegetic storytellers in the Uvod $u$ tvrđavu and in the part of Ilijasbegovići.

The focalisation positioning of the witness (taking into account the focalization model of the theorist Mieke Bal) is achieved mainly through an external focalizer (external view), which in certain places, for the impression of authenticity and persuasiveness, incorporates into its focalisation point of view and certain focalisation inserts of the witness (Gorak okus duše, Oslobađanje đavola, Prokleta ergela, part of Ilijasbegovići).

The purely internal focalization, in terms of presenting visions only from the inside, coincides with the position of the witness as a homodiegetic narrator. In this sense, the symbiosis of the "gaze" and "voice" of the witness is visible in Uvod u tvrđavu and part of Ilijasbegovići.

Taking into account the mimetic modes of Northrop Frye's fictional literature, Šehovic's romanesque witness-protagonists (fra Vincenco and don Vicko in Gorkak okus duše; Andro and Mavro in Oslobađanje đavola; Pepo and Luko in Uvod u tvrđavu; fra Ilija and fra Andrija in Prokleta ergela; Ilijas-beg - Hasan-beg - Ilijas-beg - Ilijas - Enko in Ilijasbegovići can be described as tragic because it is a case of an individual separated from society.

The figure of suffering is underlined by the continued use of the martyrological lexicon. Thus, the protagonists-witnesses are most often referred to as martyrs, and their life paths as torment and Golgoth, thus constructing primarily a Christological model of sacrifice, but also a model of sacrifice in general.

However, it is worth pointing out that the sacrifice of these characters is not of high-mimetic mode because they do not suffer from a tragic hamartia, such as Greek heroes or Christian martyrs - their sacrifice is typical or accidental. N. Frye associates this kind of sacrifice with the archetypal figure in ancient pharmacos literature (sacrificial lamb / scapegoat), which in turn can be linked to the fate of Old Testament Job. 
In this sense, Šehović's subversive reading of Job's fate is noticeable, with the man - God analogy shifted towards the man - ideology analogy. Namely, the suffering of the innocent, instead of the consolidation of faith, leads to a loss of faith and hope, to doubt of all possible types of ideological mechanisms, which, regardless of their omen, always prove to be exclusive and fatal to the existence of the "small" participant in history.

Following on from the foregoing, a whole series of Šehović's characters, both primary and secondary witnesses, participate in the construction of a moral witness figure, one that points to the negative aspects of history. During such testimony, sacrifice is set not as sublime but as a senseless act.

The narratological construction of the protagonist-witness is mainly developed by the opposition (ideological) believer-unbeliever, thus shaping the figure of (un) beliefs as the umbrella component of the thematic-ideological layer of Šehović's historical novels. Regardless of the initial degree of ideological belief, with minor or major shifts within the characterization process, all protagonist-witnesses are led to the position of ideological unbeliever.

The latter issue is directly linked (and) to the societal conflict between writer and authority. In the writer-power relationship, episodes of ideologically (un) justifiable prosecutions come to the fore in Šehović's historical novels, those that are a reaction not only to poetic action in the narrow sense, but also to any action in words that is not aligned with the coordinates of the ruling ideology. And the need to testify in these characters coincides with the need to speak authentically of the lived experience (Foucault's vision of parasian action), of imprinting the historical on personal lives, on one's own bodies.

The duty to testify is specifically embedded in the characters of writers who, not only by their own experience (as primary witnesses), but also as the addressees of the testimony of others, are artistically and intellectually responsible for taking on the role of secondary / intellectual witness (Hartman). From this angle, the purpose of testimony also stems from the fusion of the performative nature of the act of testifying with the categories of ethics.

The position of the witness in Šehović's historical novels is so emphasized that all the documents within the novel are a reflection of the speech of the witness, which makes it possible to characterize them as testimonial documents.

The imperative of writing as the topos of Šehović's novels corresponds to the idea of necessarily textual availability of the past (Hutcheon), and is largely realized by the motive of found and / or preserved records. 
The discursive classification of (testimonial) documents in Šehović's historical novels reveals their diversity: chronicles, diary fragments, epistolary records, autobiography in the narrow sense, testimonial (camp) literature, essay notes, poetic texts, oral statements and pictorial writings.

All kinds of documents, given that they start from the perception of a little man as a witness to events, are highly subjectivized. In addition, these are not documents whose authentication can be found in the archives of empirical reality, as was the case, for example, with Šenoa's preface to the documentary material. In this context, the documents in Šehović's novels are at the same time examples of the so-called weak documents but also paracitate texts.

Like other representatives of the contemporary Croatian historical novel (Fabrio, Aralica, Tomaš, Bauer ...), Šehović most often (within all his novels) refers to documentary material within the basic text (sometimes by direct quotation of witnesses' records, sometimes by reported speech). In addition, the incorporation of documents is accomplished by the use of a footnote, a preface note, but also in the case where the entire novel is entirely a sum (collection) of documents (the effect of "self-talk" records).

Šehović's novels, in their relationship to the document, completely move away from the general analogy of reality - text and focus on the relationship between texts, thus suggesting the assumption that the past reality is always textually produced.

In this vein, all the testimonial documents in the analyzed Šehović's historical novels act primarily as texts - demonstrating their intertextuality as a general feature of each text, both at the insidetextual level (among documents within individual novels) and at the level of the relationship between the documents of the novels and texts of Croatian and world literary heritage.

With a foothold in testimonial discourse, the talk of (historical) traumatic in Šehović's historical novels moves away from the sphere of writing about trauma (an attempt to objectively reconstruct past events) towards writing of trauma itself (LaCapra). Writing trauma is writing post-traumatic, affected by the process of work creation and working trough. In light of the mimetic / antimimetic model of reaction to traumatic (Ruth Leys), Šehović points to their non-exclusivity and co-existence with his novels. The concept of history in Šehović's novels, especially across the temporal dimension, corresponds to the inevitable mimetic face of the traumatic, one that involves only the possibility of infinite embodiment. History presented as cyclical, repetitive, bears the mark of 
a traumatic code: there is no way out of the past because the distinction between past, present and future is abolished, past becomes present and future.

On the micro level, the act of testimony enables an attempt to narrate the traumatic and thus the therapeutic effect. In this way, the testimony turns to the attempt to thorough elaboration, finding its place within the framework of an antimimetic reaction to the traumatic one.

Testimonial writings within novels published this century (Ilijasbegovici, Prokleta ergela), in particular the Franciscan chronicles and essayistic writings of the characters of the beys and Franciscans, are included in the sphere of cultural memory and memory by questioning the textual production of collective identity ideas.

The interactive relationship between self-concept and hetero-conceptions, whose creation can register confessional opposition (Christianity - Islam), Balkanist discourse (Todorova) and the concept of viciousness (Kristeva), builds identity models of Bosniaks (Ilijasbegovići) and Bosnian (Prokleta ergela) based on sacrifice of victimological, not the sacrificial type. The motive of shared suffering, which seeks to present the community with a testimonial act, acts as a cohesive element (Renan) when forming a collective or we-identity (Assmann), despite ethnic and confessional diversity.

Testimonial records, through their intertextual chaining, over time form the continuity of thoughts about Bosniak / Bosnian identity, as well as the image of Bosnia in the novels mentioned. Šehović's literary Bosnia grows on the features of interculturalism, which in the literary imaginary occupies a much different position from Andrić's multicultural Bosnia.

Further literary scientific interest should be directed both to a more comprehensive coverage of Feđa Šehović within the framework of Croatian literary science, to extending testimonial issues, to novels that in the narrow sense move away from the genre of the historical novel, as to the intercultural / comparative positioning (Croatian - Bosnian literature) of this contemporary writer. 


\section{SADRŽAJ}

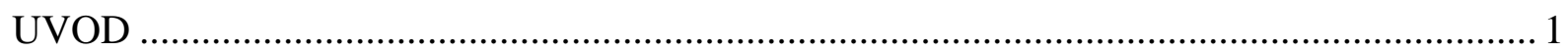

METODOLOŠKI OKVIR I PLAN ISTRAŽIVANJA …................................................. 4

1. POVIJESNI ROMANI FEĐE ŠEHOVIĆA ........................................................... 7

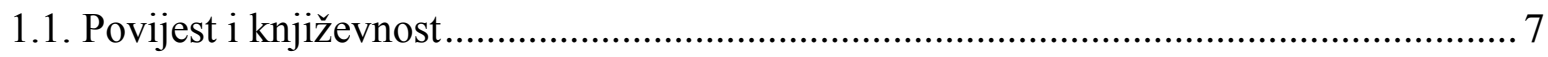

1.2. Hrvatski povijesni roman: od povijesne do novopovijesne varijante ......................... 10

1.3. Povijesni romani Feđe Šehovića u kontekstu žanra hrvatskoga povijesnog romana .... 15

2. SVJEDOČENJE, SVJEDOK: TEORIJSKA KONTEKSTUALIZACIJA .......................... 28

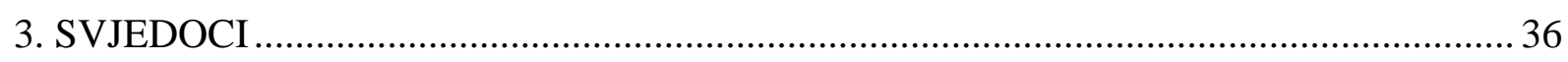

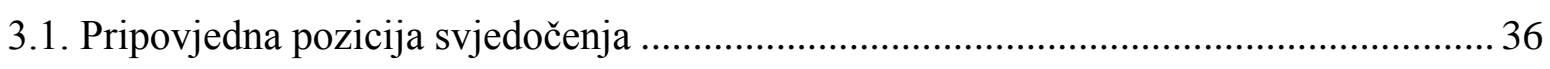

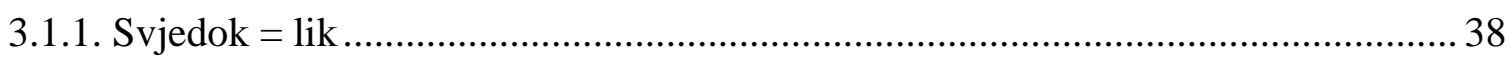

3.1.1.1. Pozivanje pripovjedača na iskaz svjedoka ............................................. 38

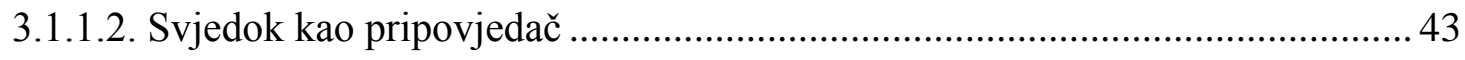

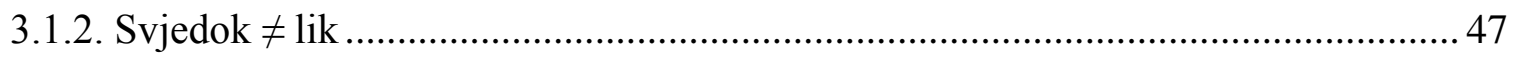

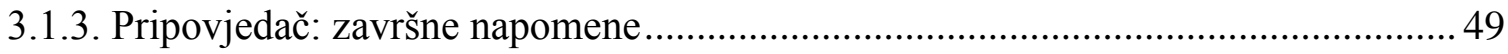

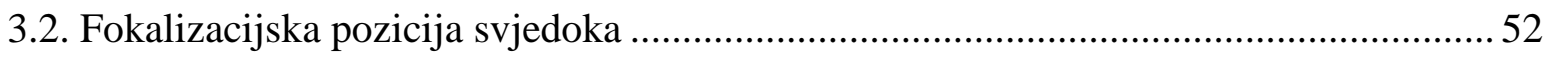

3.3. Svojstva likova svjedoka i njihova naratološka izgradnja ...................................... 57

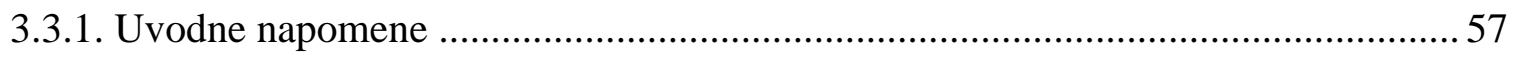

3.3.2. Patnja: provodna figura Šehovićevih povijesnih romana .................................. 60

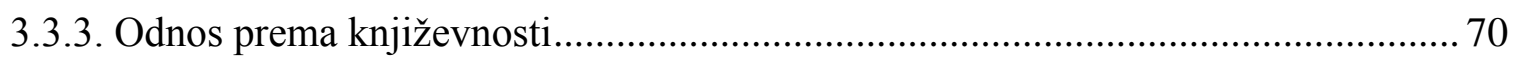

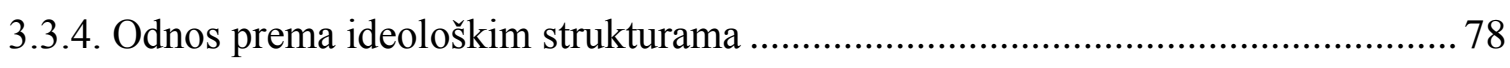

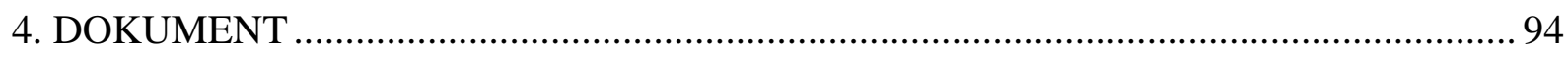

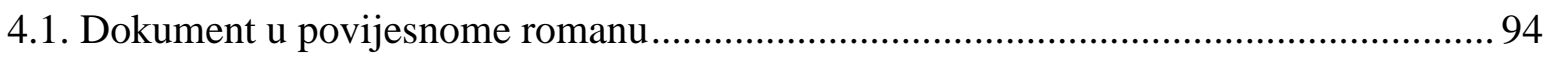

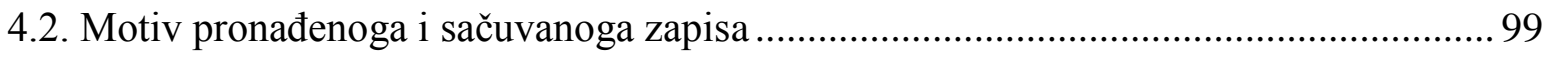

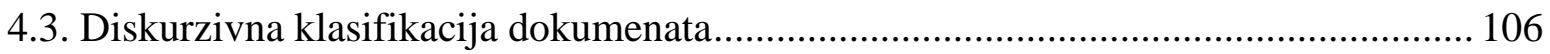

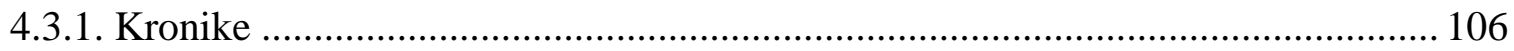




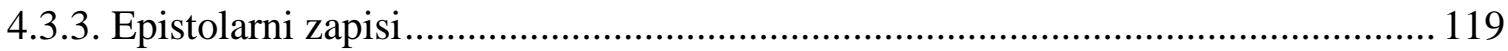

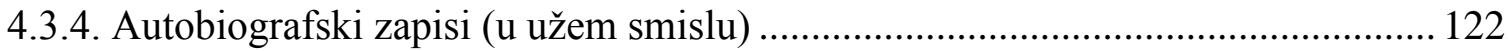

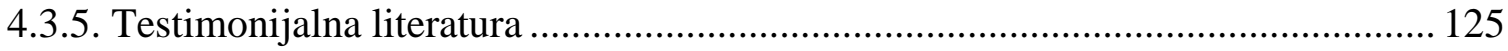

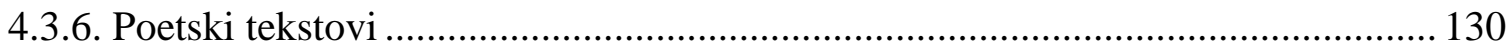

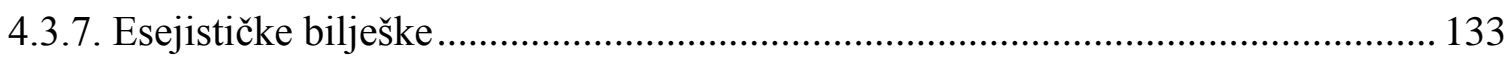

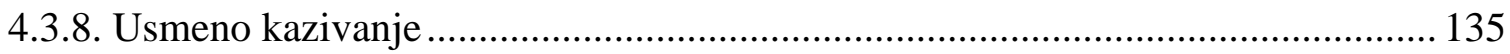

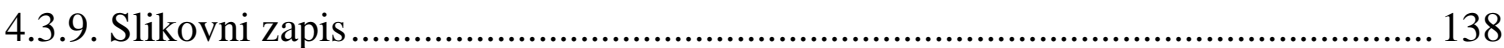

4.4. Inkorporacija dokumenata u romanesknu strukturu ................................................ 142

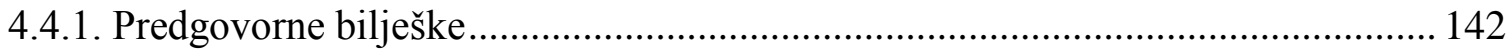

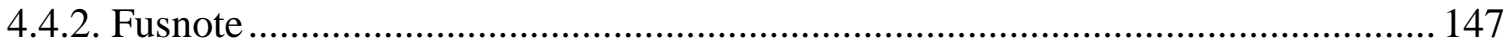

4.4.3. Pozivanje na dokument u okviru osnovnoga teksta ......................................... 152

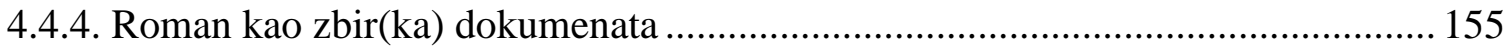

4.5. Dokument kao prostor intertekstualnih relacija....................................................... 156

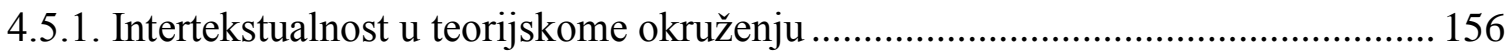

4.5.2. Intertekstualnost testimonijalnoga zapisa u kontekstu književne baštine............. 158

4.5.3. Odnos među testimonijalnim zapisima unutar Šehovićevih povijesnih romana .. 165

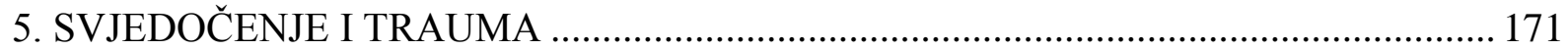

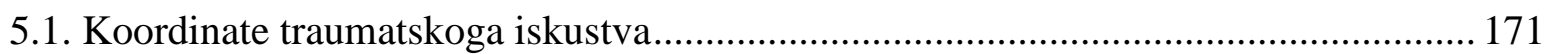

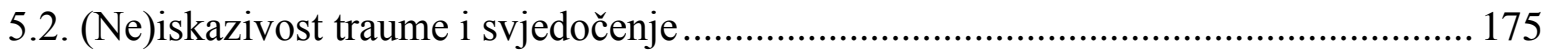

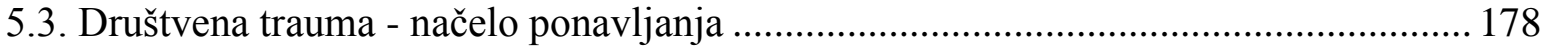

6. TESTIMONIJALNO KAO PROSTOR KREIRANJA PREDODŽBI ............................. 184

6.1. Kolektivno pamćenje/sjećanje i identitetne predodžbe ............................................ 184

6.2. Bošnjak i Bosanac kao identitetni modeli ............................................................... 188

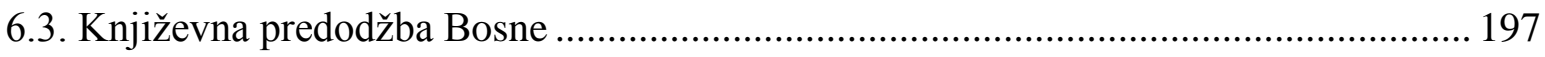

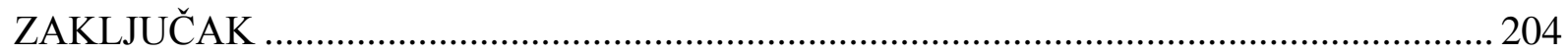

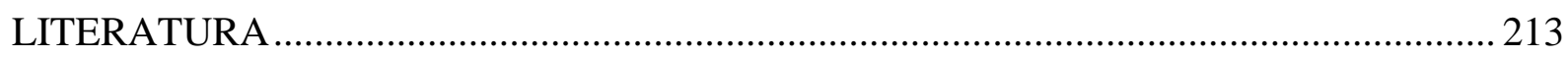




\section{UVOD}

Feđa Šehović (1930. $)^{1}$ suvremeni je hrvatski književnik orijentiran u svojim počecima na dramsko, a kasnije i na romaneskno stvaralaštvo, koje je kontinuirano obilježeno zanimanjem za povijesnu tematiku.

Uzimajući u obzir hrvatske književnike koji ostvaruju vidljive odmake od tradicionalnoga povijesnog romana šenoinskoga tipa, književna znanost reprezentante vidi u Ivanu Aralici, Nedjeljku Fabriju i Feđi Šehoviću.

Šehović se kao romanopisac od marginalne do središnje pozicije književnoznanstvenoga interesa pomaknuo nakon objavljivanja dubrovačke trilogije ${ }^{2}$, ciklusa romana napisanih pod pseudonimom Raul Mitrovich: Gorak okus duše (1983.), Oslobađanje đavola: Kronika (1986.) i Uvod u tvrđavu: Biblija za nevjernike (1989.).

Kad se devedesetih godina prošloga stoljeća aktualiziralo pitanje hrvatskoga (novo)povijesnog romana, upravo su romani ove Šehovićeve trilogije našli mjesto u znanstvenim radovima koji su naznačavali promjene u žanru hrvatskoga povijesnog romana (Viktor Žmegač, 1994; Cvjetko Milanja 1994; Julijana Matanović 1995).

Općeniti prikazi Šehovićevih romana mogu se naći u pregledima i povijestima hrvatske književnosti (Miroslav Šicel 1997; Dubravko Jelčić 2004; Slobodan Prosperov Novak 2004), a posebno u Povijesti hrvatskoga romana (1945. - 2000.) Krešimira Nemeca, gdje su Šehovićevi romani zahvaćeni u poglavlju o historiografskoj fikciji.

\footnotetext{
${ }^{1}$ Feđa Šehović rođen je u Bileći (Bosna i Hercegovina) 1930. godine. Poslije završenog Filozofskog fakulteta u Zagrebu seli se u Dubrovnik, gdje radi kao nastavnik hrvatskoga jezika u osnovnim i srednjim školama, novinar, knjižničar i voditelj Znanstvene knjižnice, voditelj Doma Marina Držića, a pri tom se kontinuirano baveći književnim radom.

„Feđu je zadnjih godina sve teže naći na njegovoj dubrovačkoj adresi, jer vrijeme uglavnom provodi na svom imanju Janino u konavoskom mjestu Vitaljini, a u Dubrovnik ga dovede tek poneki naslov.“

( Anet Franić, Feđa Šehović: Antologije sastavljaju neuspješni kazališni pisci, Slobodna Dalmacija, 22.9.2010. http://www.slobodnadalmacija.hr/scena/kultura/clanak/id/112029/fedja-sehovic-antologije-sastavljaju-neuspjelikazalisni-pisci (12. 11. 2013.)

Godine 2018. Feđi Šehoviću uručena je Nagrada „Vladimir Nazor“ za životno djelo u kategoriji Književnost (v. Nagrada Vladimir Nazor za 2017. godinu, Printera, Zagreb, lipanj 2018.).

${ }^{2}$ Analogno nazivu Vojnovićeve dramske Dubrovačke trilogije, navedeni se romani međusobnim poveznicama mogu percipirati kao još jedna dubrovačka trilogija, kako to čini Zdravko Zima u pogovoru posljednjega dijela trilogije: „Najnovijim romanom Šehović je (...) stvorio svojevrsnu Dubrovačku trilogiju pred kojom nijedan kritičar novije hrvatske proze neće moći ostati ravnodušan.“ (1989: 257)

U intervjuu za Slobodnu Dalmaciju (22. rujna 2010.), komentirajući svoju književnu produkciju, sam Šehović percipira ova tri romana kao trilogiju: „Pod istim pseudonimom izišla je trilogija (uz Gorak okus duše, još dva romana - Oslobađanje đavola i Uvod u tvrđavu), što me, reklo bi se, preko noći učinilo relevantnim piscem hrvatske proze u minulom stoljeću.“
} 
Osim u dubrovačkoj trilogiji, Šehović se povijesne tematike doticao u svim svojim romanima $^{3}$, bili oni pokušaj oslikavanja mentaliteta jednoga grada u Dubrovačkoj tralalalogiji (ciklus od šest romana iz sedamdesetih i osamdesetih godina 20. st.), romaneskni portret književnika Marina Držića u Vidri (1980.) ili kriminalistička priča smještena u osamnaestostoljetni Dubrovnik u Zločinu u samostanu (2004.). Bez obzira na povijesne motive, ovi se romani u užem smislu ne mogu promatrati unutar žanra povijesnoga romana jer autor naglasak ne stavlja na koncept povijesti; povijest je u njima više pozadina, dekor, nego sam predmet umjetničke obrade.

S druge strane, u svojim romanima ratne tematike (Domovinski rat) Četiri vozača $u$ apokalipsi (1994.) i Drž' se (b)Alija (2010.) Šehović prikazuje položaj malih pojedinačnih sudbina u povijesnome vrtlogu, ostvaruje odnos prema povijesti, ali ne može se povući paralela sada - onda, tj. zbivanja se ne mogu promatrati po principu analogija (stalno mjesto žanra hrvatskoga povijesnog romana), stoga se ni ovi romani ne mogu definirati kao povijesni romani u užem smislu.

Iz spomenutih se razloga u kontekst žanra povijesnoga romana, uz romane dubrovačke trilogije, mogu uklopiti sljedeći Šehovićevi romani: obimno petoknjižje Ilijasbegovići Cronica travuniana iz 2002. godine (1. Ilijas-beg, kapetan trebinjski; 2. Inšallah; 3. Begovina; 4. Dubrovački intermezzo; 5. Od Mostara do Haaga) te Prokleta ergela (2009.).

O Šehovićevim romanima ne postoje cjeloviti i iscrpni književnoznanstveni radovi; riječ je tek o dijelovima nekih opsežnijih studija.

Tako se lingvostilističkim pojedinostima Šehovićeva dramskoga izraza (zbirka dramskih tekstova iz 1969.) i romanesknoga izraza (prva dva dijela Dubrovačke tralalalogije) bavila Stanislava Kusijanović u svome magistarskome radu (1977.).

$\mathrm{Na}$,prisutnost““ Marina Držića u Šehovićevu opusu (dramskom i romanesknom) ukazuje Ivan Bošković (2009.), zaključivši kako se Držić pojavljuje u svim razdobljima Šehovićeva stvaranja te svim razinama (kao predtekst, kontekst i intertekst).

U kontekstu pamćenja Držića od strane hrvatskih pisaca Dunja Fališevac (2011.) upućuje kako se u Šehovićevu romanu Vidra ovaj renesansni komediograf ostvaruje kao figura pamćenja egzistencijalne ugroženosti.

\footnotetext{
${ }^{3}$ Izuzetak predstavlja roman Svi kapetanovi brodolomi (1992.).
} 
Prepoznatljivost poetičkoga univerzuma svih Šehovićevih povijesnih romana predstavlja čin svjedočenja, stoga je nužno da bilo kakav analitičko-interpretacijski pristup ovim romanima uporište gradi upravo na problematizaciji svjedočenja.

Julijana Matanović romane je dubrovačke trilogije zahvatila poglavljem o novopovijesnoj varijanti unutar svoje doktorske disertacije o povijesnome romanu u hrvatskoj književnosti 20. stoljeća (1998.), naglasivši pritom upravo Šehovićev govor svjedoka. Na mjesto dokumenta i svjedoka u novopovijesnoj varijanti hrvatskih romana ova je autorica ukazala preko esejističke rasprave (2003.) u kojoj se koristila i primjerima iz nekih povijesnih romana Feđe Šehovića (uz romane Nedjeljka Fabrija, Ivana Aralice, Stjepana Tomaša i Ivana Supeka).

Sustavniji i usmjereniji pristupi Šehovićevim romanima u književnopovijesnome i književnoteorijskome smislu ipak su izostali, posebno kad je riječ o romanima objavljenima u 21. stoljeću (petoknjižje Ilijasbegovići: Cronica travuniana i Prokleta ergela), za koje dosad nije uočen značajniji znanstveni interes.

Većina osvrta na povijesne romane Feđe Šehovića svedena je uglavnom na pogovore/predgovore te književnokritičke prikaze (npr. Zdravko Zima, Ivan J. Bošković, Luko Paljetak, Irena Lukšić, Sead Begović).

Upravo izostanak temeljitijeg i cjelovitijeg zahvaćanja Šehovićevih povijesnih romana u okviru hrvatske književne znanosti predstavlja motivacijski impuls ovome doktorskome radu.

Polazeći od hipoteze kako u kontekstu žanra hrvatskoga povijesnog romana svjedočenje predstavlja dominantnu poetičku oznaku opusa Feđe Šehovića, a time i analitičko-interpretacijsko uporište, cilj je ovoga rada problematizirati svjedočenje u povijesnim romanima Feđe Šehovića: Gorak okus duše (1983.), Oslobađanje đavola: Kronika (1986.), Uvod u tvrđavu: Biblija za nevjernike (1989.), petoknjižje Ilijasbegovići: Cronica travuniana (1. Ilijas-beg, kapetan trebinjski; 2. Inšallah; 3. Begovina; 4. Dubrovački intermezzo; 5. Od Mostara do Haaga; 2002.) i Prokleta ergela (2009.).

Koncept svjedočenja bit će razmotren u okviru problematike tipologije i pozicije svjedoka i dokumenta te konstelacije svjedočenja i pamćenja/sjećanja.

Očekuje se da će istraživanje potkrijepiti tezu o svjedočenju kao specifikumu Šehovićeve poetike te na tome tragu Šehovićev romaneskni opus sustavnije pozicionirati u kontekst žanra hrvatskoga povijesnog romana, ali potaknuti i na neka buduća istraživanja koja bi Šehovićeve povijesne romane razmotrila (i) u interkulturnome aspektu (npr. hrvatskobošnjačke književne veze). 


\section{METODOLOŠKI OKVIR I PLAN ISTRAŽIVANJA}

Sa svrhom problematizacije svjedočenja povijesni romani Feđe Šehovića (Gorak okus duše, Oslobađanje đavola, Uvod u tvrđavu, petoknjižje Ilijasbegovići, Prokleta ergela) iščitavat će se analitičko-interpretacijski, pri čemu će metodološki okvir predstavljati studije o žanrovskim obilježjima hrvatskoga povijesnog romana, naratološki instrumentarij, teorija intertekstualnosti te teorija kulturnoga pamćenja i sjećanja, u čiju sferu spadaju i teorijske postavke o svjedočenju traume te problematika konstruiranja identiteta zajednice putem svjedočenja.

U uvodnom dijelu doktorskoga rada donesen je pregled dosadašnjih istraživanja o romanesknom opusu Feđe Šehovića, obrazložila se motivacija, ciljevi i očekivani doprinos disertacije.

U ovom dijelu predstavit će se plan istraživanja (po daljnjim poglavljima rada).

Prvo poglavlje, pod nazivom „Povijesni romani Feđe Šehovića“, trodijelne je strukture.

S obzirom da pisci povijesnih romana umjetnički oblikuju fikcionalne svjetove koristeći historiografsku građu, prvi korak ovoga poglavlja predstavlja osvrt na odnos povijesti i književnosti, odnosno povijesnoga i književnoga diskurza (prema radovima Aristotela, Friedricha Nietzschea, Paula Ricoeura, Vladimira Bitija, Haydena Whitea, Linde Hutcheon).

Slijedi predstavljanje žanra hrvatskoga povijesnog romana, s naglaskom na žanrovskim promjenama, u smislu otklona od matrice tradicionalnoga povijesnog romana (Mira Sertić, Julijana Matanović, Cvjetko Milanja, Viktor Žmegač, Krešimir Nemec, Tatjana Jukić i dr.).

Tragom prethodnoga, cilj je završnoga dijela ovoga poglavlja smjestiti povijesne romane Feđe Šehovića u kontekst žanra hrvatskoga povijesnog romana.

Oslikavanjem koncepcije povijesti u Šehovićevim romanima te formalnih gradbenih elemenata kao tekstualnih indikatora žanra (Julijana Matanović) utvrdit će se kojim značajkama ovi romani slijede tradicionalnu, šenoinsku matricu hrvatskoga povijesnog romana (tzv. povijesna varijanta), a kojim pak predstavljaju otklon od te matrice (tzv. novopovijesna varijanta).

U drugome poglavlju postavit će se teorijski okvir za nastavak rada. 
U tu će svrhu biti definirane ključne terminološke odrednice - svjedočenje i svjedok (Giorgio Agamben, Jacques Derrida, Aleida Assmann, Renata Jambrešić Kirin, Kristina Peternai i dr.). Treće poglavlje disertacije usmjereno je na kategoriju svjedoka u Šehovićevim povijesnim romanima.

Radovi Gérarda Genettea, Mieke Bal, Rimmon-Kenan, Maše Grdešić i Vladimira Bitija poslužit će pri obuhvaćanju „glasa“ i „,pogleda“ svjedoka, odnosno pri klasifikaciji svjedoka prema pripovjednoj i fokalizacijskoj poziciji svjedočenja.

U slučaju pripovjedne pozicije svjedoka (svjedok kao pripovjedač, svjedok nije pripovjedač), kao i fokalizacijskoga položaja (interna fokalizacija, eksterna fokalizacija) uzet će se u obzir status svjedoka u narativu (svjedok je lik, svjedok nije lik).

Oslanjanjem na znanstvene studije Northropa Fryea, Seymoura Chatmana, Gaje Peleša, Maše Grdešić, Michela Foucaulta i dr. treće je poglavlje svojim drugim dijelom usmjereno na utvrđivanje svojstava svjedoka-protagonista u Šehovićevim romanima te na njihovu naratološku izgradnju.

U analizi likova svjedoka pritom do izražaja dolazi figura patnje kao provodna figura svih Šehovićevih povijesnih romana (likovi patnika), odnos prema književnosti te odnos prema ideološkim strukturama.

Fokus četvrtoga poglavlja predstavlja dokument kao mjesto ostvarenja testimonijalnih intencija.

Nakon definiranja pojma dokumenta u kontekstu povijesne i novopovijesne varijante hrvatskoga povijesnog romana te osvrta na važnost konvencije pronađenoga/sačuvanoga zapisa u Šehovićevim povijesnim romanima, bit će iznesena diskurzivna klasifikacija dokumenata svjedočenja u Šehovićevim romanima te će se uputiti na njihovu inkorporaciju, odnosno strategije prezentnosti u romanesknoj strukturi (oslonac u radovima Julijane Matanović, Gérarda Genetta i dr.).

Temeljeni na konvenciji pronađenoga/sačuvanoga dokumenta, Šehovićevi povijesni romani demonstriraju svijest o tekstualiziranosti povijesti (Linda Hutcheon). Također, odnos tekst - zbilja često je zamijenjen odnosom tekst - tekst, stoga će se dokumentu prići i kao prostoru neizbježnih intertekstualnih relacija, kako među zapisima unutar samih romana, tako i prema „vanjskim“ tekstovima, odnosno tekstovima književne tradicije (postavke o intertekstualnosti u studijama Julie Kristeve, Rolanda Barthesa, Dubravke Oraić Tolić, Renate Lachmann i dr.).

Peto i šesto poglavlje uključuju konstelaciju svjedočenja i pamćenja/sjećanja. 
Pamćenju i sjećanju se, na tragu teorija kulturalnoga pamćenja i sjećanja (Pierre Nora, Jan Assmann, Aleida Assmann i dr.), prilazi (i) kao društvenim fenomenima, odnosno kategorijama koje su vezane za odnos pojedinca sa zajednicom. U tom kontekstu postavljaju se sljedeće problemske smjernice: iskazivost traumatskoga iskustva putem svjedočenja (Cathy Caruth, Shoshana Felman, Aleida Assmann, Dominick LaCapra, Giorgio Agamben, Vladimir Biti) te svjedočenje u službi tvorbe identiteta zajednice posredstvom autopredodžbi i heteropredodžbi (imagološka perspektiva).

Dok će pitanja narativizacije traume putem testimonijalnih zapisa biti zahvaćena preko cjelokupnog korpusa Šehovićevih povijesnih romana, pitanja identiteta zajednice (bosanski/bošnjački identitet) do izražaja dolaze u petoknjižju Ilijasbegovići: Cronica travuniana i Prokletoj ergeli, romanima koji svoje fabularne okosnice grade na predodžbama o Bosni.

Tragom prethodno rečenoga, u narednim bi istraživanjima predodžbe o Bosni i bosanskom/bošnjačkom identitetu u Šehovićevim romanima valjalo dovesti u vezu s analognim temama u bosanskom/bošnjačkom povijesnome romanu te time Feđu Šehovića smjestiti i u interkulturni kontekst povijesti književnosti. 


\section{POVIJESNI ROMANI FEĐE ŠEHOVIĆA}

\subsection{Povijest ${ }^{4}$ i književnost}

S obzirom da pisci romana povijesne tematike umjetnički oblikuju fikcionalne svjetove koristeći historiografsku građu, nužno se osvrnuti na odnos književnoga i povijesnoga diskurza. $^{5}$

Rasprave o odnosu povijesti i književnosti sežu još u antičko razdoblje kad je, pišući o „pjesničkom umijeću“, Aristotel razliku između historiografa i književnika povezao s različitim stupnjem istine u njihovim djelatnostima:

„Povjesničar i pjesnik (...) razlikuju se time što jedan pripovijeda stvarne događaje, a drugi ono što bi se moglo očekivati da se dogodi. Zato je pjesničko umijeće filozofskije od povijesti i treba ga shvatiti ozbiljnije od nje. Pjesništvo, naime, govori više ono što je općenito, a povijest ono što je pojedinačno.“(2005: 21)

Utvrđivanje koncepta povijesti nezaobilazna je točka analize romana povijesne tematike. Unatoč njihovoj brojnosti, koncepti povijesti mogu se svesti na dva oprečna: teleološki pristup povijesti, koji podrazumijeva progres, odnosno ideju povijesnoga napretka, te neteleološki, koji povijest redovito promatra kao određenu vrstu reverzibilnosti ${ }^{6}$.

Znanstvena literatura koja se bavi povijesnim romanima redovito se oslanja na Nietzscheovu tipologiju shvaćanja povijesti. Friedrich Nietzshe u svome djelu O korisnosti $i$ štetnosti historije za život predstavlja trijadni odnos prema povijesti: monumentalistički, antikvarni i kritički. Monumentalistički pristup vidi povijest kao ,velike momente kojima se

\footnotetext{
${ }^{4}$ U okviru terminoloških distinkcija prošlost - povijest - historija - historiografija, povjesničarka Mirjana Gross u Suvremenoj historiografiji (2001.), oslanjajući se na etimološka tumačenja i tradiciju, koristi izraz povijest u značenju povijesne, tj. prošle zbilje te povijesnog kretanja uopće, a historiju kao bilo kakvo bavljenje prošlošću. Znanstvenu ili profesionalnu historiju naziva historijskom znanosti, a historiografijom pisano izlaganje rezultata istraživanja, odnosno skup historijskih djela.

Povijest kao termin suprotstavljen književnosti u ovome će dijelu rada biti korišten u smislu historiografije (pisanja povijesti) kao znanstvenog proučavanja prošlih događaja, a na nekim mjestima i kao oznaka za povijesno kretanje općenito (npr. koncepti povijesti).

${ }_{5}^{5}$ Michael Foucault diskurz smatra ,okvirnim uvjetom nastanka predodžbi, spoznaja, govora, postupaka i oblika društvenosti jedne civilizacije, njezinim konstitucijskim temeljem“ (Biti 2000a: 78).

${ }^{6}$ Vidi: Milanja, Cvjetko. 1994. Hrvatski novopovijesni roman (ulomak iz veće cjeline). Kolo, 11-12: 1082.

Nemec, Krešimir. 2003. Povijest hrvatskog romana: od 1945. do 2000. Zagreb, Školska knjiga: 267-268.
} 
vezuje gorski vijenac čovječanstva kroz tisućljeća“ (2004: 20). U ovome je slučaju povijest učiteljica jer veličine koje su jednom postojale opet mogu biti moguće.

Za razliku od ovoga pristupa, po kojem bi mnogi dijelovi prošlosti bili izgubljeni jer nisu dovoljno veliki i značajni, antikvarni pristup sve u prošlosti uzima kao jednako važno, sve staro vrijedno je štovanja. Za Nietzschea opasnost ovakvoga pristupa leži u činjenici da se podcjenjuje sve što je u nastajanju, a tako se priječi odlučnost za novo.

Iako to nigdje izričito ne navodi, može se zaključiti kako je kritički pristup historiji za Nietzschea najprihvatljiviji. Upravo kritički pristup ovaj filozof definira kao čovjeku nužno potreban, naglašavajući kako se prošlost treba izvesti pred sud:

„Čovjek mora imati snage da razori i razriješi prošlost da bi mogao živjeti.“ (2004: 30)

Devetnaestostoljetni je historizam zagovarao „objektivnu činjeničnu građu koju 'valja pustiti da sama govori' (Leopold von Ranke prema Biti 2000a: 180) odbacujući tako subjektivizam, a time i bilo kakvu fikcionalnost u prikazivanju prošlosti, želeći stvoriti jedinstvenu sliku povijesnih zbivanja.

Novi historizam, koji se javlja osamdesetih godina 20. st. u SAD-u,

„na mjesto homogene slike razdoblja dovodi tekstualizirano poprište silnica koje se natječu oko proizvodnje te slike. Novi historizam ne priznaje ni jednoj praksi teorijsko 'pravo na zbilju', odnosno na njezino objektivno opisivanje. Svaka praksa tako proizvodi svoju zbilju te se u tom smislu može jedino smatrati književnom“" (Biti 2000a: 184).

Pripadnici novoga historizma ,ne inzistiraju više na ulozi objektivnog promatrača 'istine', 'smisla' povijesti, već prihvaćaju položaj pripovjedača u pripovijedanju književno/povijesnih pripovijesti“ (Šporer 2005: 147).

Vidljivo je da novohistoricistička gledišta, koja se poklapaju s dolaskom postmodernističkih strujanja, donose promjene u odnos povijest - književnost. Umjesto razlika, sve se više naglašavaju dodirne točke ovih dvaju područja.

Vladimir Biti uviđa dvoznačnost pojma „historiografska fikcija“, pojma koji naglašava činjenicu da se historiografija očituje kao ujedno presupozicijski diskurz (fikcionalnost), a književnost kao ujedno propozicijski diskurz (fakcionalnost, znanstvenost) (Biti 2000b: 32 33). 
Ovakvo je gledanje na historiografsku fikciju na tragu postavaka Paula Ricoeura, koji preplitanje historije i fikcije vidi u fikcionalizaciji historije i historizaciji fikcije (1990.) ${ }^{7}$.

Jedno od najradikalnijih tumačenja odnosa povijesti i književnosti nudi Hayden White. Za ovoga je američkog filozofa i povjesničara povijest, koja opisuje i prepričava prošle događaje, uvijek priča (pri/povijest), a priče, kao činjenične tvrdnje, lingvističke su tvorevine i pripadaju redu diskurza (2004: 621 - 635). U tom smislu moglo bi se podvući kako su za Whitea književnost i povijest podjednako figurativne (Biti 2000a : 403).

Kao važnu dodirnu točku povijesti i književnosti u daljnjem je izlaganju nužno istaknuti svjesnost o tekstualiziranosti. I književnost, koju se veže uz pojam fikcije, i historiografija, koju se veže uz pojam fakcije ${ }^{8}$, dodiruju se u pojmu interteksta.

Posmoderna intertekstualnost upućuje da uvijek postoje „samo tekstovi, već jednom napisani“ (Hutcheon 1988: 118), odnosno da ,poznajemo prošlost (koja je zaista postojala) samo putem njezinih tekstualiziranih ostataka“ (Hutcheon 1988: 119).

Kanadska teoretičarka Linda Hutcheon svojoj je kovanici „historiografska metafikcija“99 osigurala mjesto u svim znanstvenim radovima postmoderne koji se bave književnim i historiografskim diskursom. Primjenjujući taj pojam na suvremene povijesne romane anglofonog područja, koji nastaju u okrilju postmodernističkih strujanja, autorica dovodi u vezu historiografiju, književnost (fikciju) i teoriju (predmetkom meta-, čime se naglašava samosvijest djela koja su etiketirana kao historiografska metafikcija).

Oslanjajući se na postavke Györgyja Lukácsa o klasičnom povijesnom romanu (Hutcheon ih naziva historiografskom fikcijom), ova autorica bilježi otklone historiografske metafikcije od Lukácsevih opisa te zaključuje:

„Historiografska metafikcija problematizira sve što je povijesni roman jednom uzeo zdravo za gotovo; historiografska metafikcija destabilizira prihvaćene predstave o povijesti i fikciji.“ (1988: 120)

Koliko je ova žanrovska kovanica primjenjiva na suvremene hrvatske povijesne romane, pokazat će naredno poglavlje. Na kraju ovoga poglavlja valja se osvrnuti na njegov početak:

\footnotetext{
${ }^{7}$ „Historija je gotovo fiktivna utoliko što kvazi-prisutnost događaja, stavljanih 'pred oči' čitatelju pomoću životne priče, nadoknađuje svojom intuitivnošću i živošću eluzivni karakter prošlosnosti prošloga, što ilustriraju paradoksi predstavnosti.

Fikcijska priča je gotovo historijska u onoj mjeri u kojoj se nezbiljski događaji, koje on prenosi, za pripovjedni glas koji se obraća čitaocu prošle činjenice; oni time nalikuju prošlim događajima, a fikcija nalikuje historiji.“ (Ricoeur 1990: 245 - 246)

${ }^{8}$ Iz prethodnoga proizlazi da se područja fikcije i fakcije sve češće vide kao fluidna, s težnjom međusobnog ispreplitanja.

${ }^{9}$ Najpopularniji izraz iz njezine Poetike postmodernizma: povijest, teorija, fikcija upravo je ,historiografska metafikcija“.
} 
aristotelovsko strogo razdvajanje povijesti i književnosti u postmoderno doba ne može zadobiti svoju potpunu opravdanost. Vidljivo je to posebno pri proučavanja suvremenih povijesnih romana, gdje promišljanje o pisanju književnosti nužno uključuje i promišljanje o pisanju povijesti.

\subsection{Hrvatski povijesni roman: od povijesne do novopovijesne varijante}

Istaknuti teoretičar romana György Lukács, problematizirajući odnos romana i povijesne zbilje (1986: 155 - 164), nastanak povijesnoga romana veže za početak 19. stoljeća, otprilike u vrijeme pada Napoleona. Ovaj autor smatra kako su, u odnosu na apsolutističke ratove predrevolucionarnoga doba, Francuska revolucija i Napoleonovi ratovi ,učinili historiju masovnim doživljajem“ (159). Ono što je nekad bilo iskustvo pojedinaca (pripadnika malih profesionalnih vojski) sada postaje iskustvo širokih masa. Snaga nacionalnih osjećaja dovodi do potrebe za razumijevanjem povijesnih događaja:

„Tako su stvorene konkretne mogućnosti da ljudi svoju egzistenciju shvate kao nešto historijski uvjetovano, da u historiji vide nešto što zadire duboko u svakodnevni život i što ih se neposredno tiče.“ (161)

Na podlozi političko-ekonomskih promjena koje su zahvatile čitavu Europu nakon Francuske revolucije izrastaju djela Waltera Scotta (Waverly, Rob Roy, Ivanhoe...), pisca kojega Lukács drži začetnikom žanra povijesnoga romana. Tvrdi da su romani povijesne tematike prije Scotta bili povijesni samo po svojim vanjskim obilježjima, po „kostimima“; tek je Walter Scott uspio ,pjesničkim sredstvima dokazati postojanje ono 'baš je tako bilo' historijskih okolnosti i likova“"(179).

Najuvjerljiviji predstavnik scottovskog tipa romana u hrvatskoj književnosti zasigurno je August Šenoa (Zlatarovo zlato, Čuvaj se senjske ruke, Seljačka buna, Diogenes, Kletva). Ovaj književnik nastoji postići autentičnost i vjerno predočiti povijesne događaje koje tematizira, pri čemu dojam istinitosti i uvjerljivosti redovito ostvaruje i u svojim bogatim predgovornim bilješkama.

Analizirajući stilske osobine hrvatskoga historijskog romana, Mira Sertić (1970.) navodi kako Šenoa Scotta slijedi ponajviše u kompoziciji: povijesni su događaji u pozadini, 
historijske ličnosti imaju ulogu epizodnih lica, a nosioci glavne radnje jesu historijski slabo provjerljiva ili potpuno izmišljena lica.

U galeriji hrvatskih povijesnih romana (romani Augusta Šenoe, Josipa Eugena Tomića, Eugena Kumičića, Hinka Davile, Milutina Mayera, Ksavera Šandora Gjalskoga i Milutina Cihlara Nehajeva) Sertić podcrtava njihova zajednička stilska obilježja: kronikalni stil, patos i sentimentalizam (v. 253).

U završnome dijelu svojega rada Sertić se osvrće na roman Milutina Cihlara Nehajeva Vuci (1928.) naglašavajući da, iako po tematsko-idejnome sloju ovaj roman slijedi liniju dotadašnjih povijesnih romana (jaka povijesna ličnost, kronikalni stil, patetika, naglašeni patriotizam, nastojanje da se vjerno slijede povijesni izvori), od njih se izdvaja po tome što više nije riječ o romanu zbivanja nego o „romanu ličnosti - romansiranoj biografiji“ (252). Nehajev psihološki produbljuje lik Frana Krste Frankopana, naglašava njegovu osamljenost, „skinuo ga je s pijedestala heroja“ (251).

Upravo ovaj Nehajevljev roman za Julijanu Matanović, autoricu koja se kontinuirano u svojem književnoznanstvenome radu bavi romanima povijesne tematike, sadrži mjesto koje predstavlja „startnu poziciju hrvatskog novopovijesnog romana“, s obzirom da već tu ,povijest prestaje biti učiteljicom života i nudi nam se kao zbroj tragičnih, pojedinačnih sudbina koje čitatelji prepoznaju kao dijelove svojih vlastitih biografija“" (Matanović 1995: $101-102)$.

Cvjetko Milanja u svome radu o hrvatskome novopovijesnom romanu (1994.) vidi pak Danuncijadu (1946.) Viktora Cara Emina kao polazišno mjesto novopovijesne varijante, zaključivši kako je od tog romana pa nadalje ,,politički segment 'onečistio' povijesnu projekciju, nedvojbeno ukazujući na karakter neuzoritosti takva modela povijesti“ (1083).

Vidljivo je da termin novopovijesni roman ne treba tretirati kao opreku tradicionalnom/scottovskom/šenoinskom romanu. Riječ je o pokušaju imenovanja etapa u razvoju hrvatskoga povijesnog romana, $i$ to ne u smislu nekih oštrih rezova, nego prirodne linije razvitka žanra tijekom vremena. Novopovijesna varijanta izrasta iz povijesne varijante povijesnoga romana, poslije čega koegzistiraju u književnome prostoru, s tim da $\mathrm{u}$ postmodernističko vrijeme dominacija pripada novopovijesnoj varijanti.

Ustrajući upravo na isticanju kontinuiranosti žanra povijesnoga romana u hrvatskoj književnosti, jer uostalom „nema većeg vremenskog razmaka od $1866 .{ }^{10}$ do današnjih dana, u

\footnotetext{
${ }^{10}$ Autorica misli na roman Ivana Krstitelja Tkalčića Severila ili slika progonstva kršćanah u Sisku, roman koji je Krešimir Nemec okarakterizirao kao ,prvi hrvatski povijesni roman“. Vidi: Nemec, Krešimir. 1992. Prvi hrvatski povijesni roman. Mogućnosti, god. 39, br. 5 - 6 - 7: 531 - 537.
} 
kojem se ne bi otkrio barem jedan roman na povijesnu temu“ (Matanović 1995: 99), pregledi i povijesti hrvatske književnosti (Šicel: 1997; Jelčić: 2004; Novak: 2004) uglavnom se drže termina povijesni roman, proširivši ga tek povremeno vremenskim odrednicama (moderni povijesni roman, suvremeni povijesni roman...).

Odrednica novopovijesni roman zaživjela je devedesetih godina prošloga stoljeća u radovima Cvjetka Milanje (1994.) i Julijane Matanović (1995.).

Riječ je o vremenu u kojem ratna previranja rađaju intenzivniju potrebu za revizijom odnosa prema romanima koji se bave nacionalnom poviješću.

Pišući još 1991. godine ${ }^{11}$ o promijenjenoj paradigmi hrvatskoga povijesnog romana, u odnosu na šenoinski tip, Viktor Žmegač (1994.) uglavnom se zadržava na ustaljenom terminu povijesni roman, dodajući mu tek atribute koji ga smještaju u neko drugo vrijeme: povijesni roman danas, današnji povijesni roman, novi povijesni roman (nasuprot starom povijesnom romanu).

Uzimajući u obzir književnike koji svojim romanima povijesne tematike ostvaruju vidljive odmake od klasičnoga povijesnog romana, pregledima i povijestima hrvatske književnosti ( Šicel: 1997; Nemec: 2003; Jelčić: 2004; Novak: 2004) dominiraju tri imena: Ivan Aralica (posebno njegov roman Psi u trgovištu), Nedjeljko Fabrio ( tzv. Jadranska trilogija - Vježbanje života, Berenikina kosa, Triemeron) i Feđa Šehović (tzv. Dubrovačka trilogija - Gorak okus duše, Oslobađanje đavola, Uvod u tvrđavu). ${ }^{12}$

Žanr povijesnoga romana trebao bi, prema Cvjetku Milanji, biti proučavan s dvojakog stajališta: problematizacije općeg koncepta povijesti u tim romanima te funkcioniranja historiografskoga sloja u romanesknoj strukturi (1994: 1077).

\footnotetext{
${ }^{11}$ Žmegačev rad Povijesni roman danas prvi je put objavljen 1991. u Republici, god. XLVII, br. 5 - 6, str. 58 75 (prema Matanović 1998: 357).

${ }^{12}$ Rad Julijane Matanović Hrvatski novopovijesni roman (1995.) donosi podulji popis autora koji se uklapaju u novopovijesnu varijantu žanra hrvatskoga povijesnog romana u 20. stoljeću:

Ivan Aralica, Psi u trgovištu (1979.)

Nedjeljko Fabrio, Vježbanje života (1985.), Berenikina kosa (1989.), Smrt Vronskoga (1994.)

Feđa Šehović, Gorak okus duše (1983.), Oslobađanje đavola (1986.), Uvod u tvrđavu (1989.)

Ivan Supek, Buna Janusa Pannoniusa (1992.)

Ivica Ivanac, U službi Josipa baruna Jelačića (1990.)

Stjepan Tomaš, Zlatousti (1993.), Srpski bog Mars (rukopis - u trenutku objave ovoga rada Julijane Matanović) Autorica ističe kako bi šira analiza uključivala i ove romane:

Leo Držić, Magarcima pucaju rebra (1980.)

Lijerka Damjanov Pintar, Legenda i zbilja (1993.)

Jure Karakaš, Krbavska bitka (1994.)

Višnja Stahuljak, Zlatna vuga (rukopis - u trenutku objave ovoga rada Julijane Matanović)

Cjelovit pregled autora povijesne i novopovijesne varijante hrvatskoga povijesnog romana u 20. st. valja pogledati u doktorskoj disertaciji Julijane Matanović Povijesni roman u hrvatskoj književnosti XX. stoljeća (1998.).
} 
U slučaju pojedinih romana prethodno spomenutih književnika književnoznanstvena literatura redovito spominje popularnu krilaticu o povijesti koja više nije učiteljica života, a što se može dovesti u vezu s cikličkom naravi, kao tipom neteleološkoga poimanja povijesti.

Reverzibilnost povijesnih procesa uvijek donosi ponovni poraz za pojedinačnu egzistenciju, stoga se novopovijesni romani mogu redovito iščitavati kao alegorične, parabolične priče o odnosu politike i pojedinca (v. Milanja 1994: 1085; Jelčić 2004: 540; Nemec 2003: 268) . O alegorijskome romanu kao tipu povijesnoga romana govori Pavao Pavličić u svome „Pismu Madoni Markantunovoj““(1995: 123 - 124) ${ }^{13}$. Takav tip povijesnoga romana može se povezati s novopovijesnom varijantom, a Pavličić u tom slučaju govori o analogijama koje se uspostavljaju između prošlosti i sadašnjosti, dakle o nekakvoj vrsti univerzalnih povijesnih scenarija.

Na ovome mjestu valja napomenuti kako su analogije prošlosti i sadašnjosti zajedničko svojstvo obiju varijanti hrvatskoga povijesnog romana. Šenoino geslo izneseno u Vijencu još 1874. kako „u historičkom romanu moraš analogijom između prošlosti i sadašnjosti narod dovesti do spoznaje samog sebe“"14 aktualno je i u novopovijesnoj varijanti povijesnoga romana.

Uzevši u obzir Nietzscheovu tipologiju odnosa prema povijesti, zamjećuje se da romani povijesne tematike koji nastaju već od kraja sedamdesetih godina 20. st. sve češce uvode kritički odnos prema povijesti i time se suprotstavljaju tzv. šenoinskom modelu povijesnoga romana, koji se uglavnom zadržao u monumentalnom i antikvarnom ozračju. Što se tiče drugog Milanjina (1994.) zahtjeva - proučavanja funkcije historiografskoga sloja u romanesknoj strukturi - može se u suvremenim romanima povijesne tematike uočiti drugačiji odnos prema historiografskoj građi.

Za razliku od šenoinske paradigme povijesnoga romana, gdje je bilo važno vjerno rekonstruirati određeni povijesni trenutak, oslanjati se na općeprihvaćene dokumente, a velike povijesne istine nisu dovođene u pitanje, nova paradigma povijesnoga romana progovara o relativnosti svakog povijesnoga prikaza, pobuđujući u čitateljima osjećaj sumnje.

\footnotetext{
${ }^{13}$ U „Pismu Madoni Markantunovoj“, jednom od pisama slavnim ženama u njegovu Rukoljubu, Pavličić donosi tipove povijesnoga romana: apološki (povijest kao uzor sadašnjega stanja), didaktički (povijest kao uzrok sadašnjega stanja) i alegorijski (povijest kao alegorija sadašnjice). Kao četvrti tip spominje onaj koji ne postoji u hrvatskoj književnosti - postmodernistički ili posthistorijski (povijest kao riznica iz koje se može uzimati, i u nju opet vraćati, u kojoj je važno i nevažno, veliko i malo, uzvišeno i svakodnevno, stavljeno na istu razinu). Zanimljiva je Pavličićeva konstatacija kako su svi naši romani uvijek povijesni jer za hrvatski narod povijest još uvijek traje: „Mi nismo ušli ni u postmodernu ni u posthistoriju, mi smo, poštovana konteso, u povijesti do grla.“(127) Vidi: Pavličić, Pavao. 1995. Pismo Madoni Markantunovoj. U: Rukoljub: Pisma slavnim ženama, 117 - 130. Zagreb: Slon.

${ }^{14}$ August Šenoa: Zabavna knjižnica, Vijenac, god. VI/1874, broj 28, str. 443 (prema Matanović 1998: 41)
} 
Što se tiče konteksta u koji bi se mogli smjestiti novi romani o povijesti, većina autora koji su problematizirali nove hrvatske romane povijesne tematike drže kako ih treba proučavati kao odraz određenih postmodernističkih strujanja (usp. npr. Milanja 1994: 1077 1082; Šicel 1997: 255; Nemec 2003: 265 - 268).

Povjesničar hrvatske književnosti Slobodan P. Novak, s druge strane, ne dovodi u vezu promjene na području povijesnoga romana s postmodernizmom, već povijesni žanr u hrvatskoj književnosti prvenstveno vidi kao odgovor na određene nacionalne težnje (2004: 216).

Krešimir Nemec u svojoj Povijesti hrvatskoga romana: od 1945. do 2000. (2003.) jedini je od spomenutih povjesničara hrvatske književnosti tematsko-strukturalne promjene $u$ hrvatskome povijesnom romanu doveo u vezu s romanima iz stranih književnosti. Poglavlje u kojem obrađuje korpus hrvatskih romana koji bi odgovarali novopovijesnoj varijanti imenuje „Historiografska fikcija“, čime se tek djelomično oslanja na žanrovsku kovanicu Linde Hutcheon, s obzirom da iz nje ispušta prefiks meta-.

Nakon što je uvodni dio poglavlja o historiografskoj fikciji posvetio prezentaciji suvremenih povijesnih romana u stranim književnostima ${ }^{15}$, koji za razliku od klasičnoga povijesnog romana naglašavaju neodređenost, nepouzdanost povijesne građe, i pri tom se ironično poigravaju istinama i lažima povijesnog bilježenja, ovaj povjesničar zaključuje kako „tek skromne odjeke takvih tendencija i postupaka bilježimo i u našoj sredini““ (266).

Pri tome misli na činjenicu da su u hrvatskoj književnosti rijetki povijesni romani koji ostvaruju humorno-ironijsku i parodijsku formu ${ }^{16}$.

Kad je riječ o primjeni termina historiografska metafikcija na hrvatske romane o povijesti, Tatjana Jukić mišljenja je kako bi se u tom slučaju trebalo govoriti o „,specifičnoj, hrvatskoj varijanti historiografske metafikcije“ (2003: 134).

Jukić, kao i Nemec, ističe odsutnost parodijske forme hrvatskih romana s temom povijesti, pripisujući toj činjenici kao uzrok traumatičan karakter hrvatske povijesti:

„Nasuprot ludističkoj, paranoidnoj ali parodičnoj, sebesvjesnoj povjesnici anakronizama, anomalije, apokrifa i aberacija, stoji povijest traume i njezina mučnog transfera u prikazivo“ (139).

\footnotetext{
${ }^{15}$ Vergilijeva smrt Hermana Brocha, Hadrijanovi memoari Marguerite Yourcenar, Žena francuskog poručnika Johna Fowlesa, Ime ruže Umberta Ecca (Nemec 2003: 265)

${ }^{16}$ Nemec (2003: 268) pronalazi tek nekoliko iznimaka: Magarcima pucaju rebra (1980.) Lea Držića, U službi Josipa baruna Jelačića (1990.) Ivice Ivanca, Medvedgradski golubovi (1995.) Ivana Kušana, I norija je meštrija (1994.) Pere Budaka.
} 
Ne začuđuje stoga činjenica da su hrvatski novopovijesni romani, poput svojih prethodnika, obilježeni moraliziranjem, djelujući tako poučno na svoje čitatelje.

$\mathrm{Na}$ tragu spomenute povijesti traume, prizori „mučenja, nasilja, progona, izdaja i poniženja“ (Žmegač 1994: 86) reprezentativni su upravo za Šehovićeve povijesne romane, s tim kako Žmegač ističe da ,traži li se motto za nove romane o povijesti, pogodan se sažetak može naći u jednoj od (fikcionalnih) pjesama koje je napisao dum Vicko, junak Mitrovicheva romana Gorak okus duše:

„Sve je u znaku bezumlja moći, / sve je u vlasti i pod vlašću, / nutrinu plave Sahare beznađa...“(1994: 87).

\subsection{Povijesni romani Feđe Šehovića u kontekstu žanra hrvatskoga povijesnog romana}

U ovome potpoglavlju analizirani će korpus Šehovićevih povijesnih romana biti razmatran u kontekstu (novo)povijesne varijante hrvatskoga povijesnog romana. ${ }^{17}$

Potrebno je utvrditi po kojim elementima ovi romani slijede tradicionalnu matricu hrvatskoga povijesnog romana (povijesna varijanta), a u kojim elementima oni predstavljaju otklon od te matrice (novopovijesna varijanta).

Polazeći od tvrdnje Julijane Matanović kako je ,autorovo poimanje povijesti jedini pouzdani temelj za utvrđivanje generičke pripadnosti romana“ (1998: 5), na početku se nužno osvrnuti na koncepciju povijesti u Šehovićevim romanima.

„Velikoj priči Povijesti/Politike pripovjedač suprotstavlja male priče i zgode o pojedincu, o individuima.“ (Milanja 1994: 1087) Šehovićevi likovi „malih“ pojedinaca u sukobu s povijesnim gibanjima doživljavaju tek patnju, beznađe, poraz, nemogućnost bilo kakve vrste optimizma i napretka.

Vincenco, a potom i njegov nećak Vicko, likovi iz Gorkoga okusa duše, iako suprotnih svjetonazora po pitanju bilo kakve isključivosti, umiru u beznađu, osjetivši na vlastitoj koži sve fizičke i psihičke torture vladajućih društvenih mehanizama.

\footnotetext{
${ }^{17}$ Termin varijanta (povijesna i novopovijesna varijanta) u kontekstu promjena unutar razvoja hrvatskoga povijesnog romana redovito koristi Julijana Matanović (v. npr. 1995, 1998, 2003...).

U istom smislu, primjerice Viktor Žmegač govori o promijenjenoj paradigmi hrvatskoga povijesnog romana: nasuprot staroj, šenoinskoj paradigmi povijesnoga romana stoji nova paradigma hrvatskoga povijesnog romana (v. 1994).
} 
Oslobađanje đavola donosi ideju repetitivnog karaktera velikih povijesnih katastrofa (simbolika potresa) utemeljenih upravo na ljudskoj nemogućnosti učenja iz povijesti. Riječi jednoga od svjedoka potresa s početka romana funkcioniraju kao univerzalni iskaz o povijesti koja više nije učiteljica života:

„'To je ono', piše gospar Nikša, 'zbog čega ćemo jednom morati zauvijek propasti (...) Velika i sveuništavajuća pošast treba se tek dogoditi, sutra ili za koji decenij, ali dogodit će se zato što ni iz ove strašne nesreće sigurno nećemo izvući nikakve pouke, kao što nismo ni iz onih prethodnih. A đavo upravo najviše računa na ljudsku zaboravnost i uz njenu pomoć ponavlja našu užasnu povijest.'“ (OĐ: 8$)^{18}$.

Ovakvo je gledište u skladu s proročanstvima jednog od likova romana. Naime, Luko, poznati dubrovački fizičar kršćanskog svjetonazora, u svojoj raspravi navodi godine budućih potresa u Dubrovniku:

„1632., 1657., 1667., 1689., 1782., 1800., 1821., 1838., 1851., 1876., 1898., 1902., 1925., 1939., 1961., 1979., 1989., 1993., 1999., 2010., 2018.“(ОĐ: 12).

Veliki dubrovački potres iz 1667. tako je u ovome romanu problematiziran kao obrazac koji će se ponavljati upravo zato što povijest više nije magistra vitae.

Posljednji roman trilogije, Uvod u tvrđavu, tematizira traumatska iskustva pojedinaca pod totalitarnim sustavima 20. stoljeća. Bez obzira kojoj ideološkoj struji pripadali, likovi malih pojedinaca osuđeni su na poraz. I Pepa kao političkoga ,vjernika“ (komunistička ideologija) i Luku kao „nevjernika“ zahvatit će ista sudbina. Za ove likove nema izlaska iz kruga patnje, stoga je fabula organizirana kao kontinuirano izmjenjivanje različitih oblika nesreća: boravci po logorima (od Auschwitza preko Jadwige, Papinke, Norilska i Krasnojarska do Gologa otoka), zatvorska mučenja, politički progoni.

Fabularna linija Proklete ergele organizirana je u dva dijela (drugi dio znatno je dulji), a temelji se na oslobađanju Klisa od Turaka 1596. i 1648. godine. Tako Klis postaje mjesto sukoba turske i mletačke sile (proširene tada i na područje Splita), odnosno mjesto sukoba Istoka i Zapada.

Ilija i Andrija likovi su bosanskih franjevaca kojima je dodijeljena uloga posrednika među zaraćenim stranama, a time i uloga nositelja interkulturnoga dijaloga. Fra Ilija u prvome dijelu

\footnotetext{
${ }^{18}$ Radi lakšeg snalaženja i ekonomičnosti u zagradama će uz lik ili citat iz djela kraticom biti naznačen naslov romana: GOD (Gorak okus duše), OĐ (Oslobađanje đavola), UUT (Uvod u tvrđavu), I (Ilijasbgovići), PE (Prokleta ergela).
} 
romana i fra Andrija u drugome dijelu romana imaju potpuno isti zadatak: voditi pregovore o uvjetima okončanja kršćansko-muslimanskoga sukoba na Klisu.

Ilija je svojim pregovaračkim vještinama nastojao spriječiti tursko iskaljivanje gnjeva nad poraženim kršćanskim braniteljima tvrđave. Istovjetna se pregovaračka situacija u romanu odigrala pedesetak godina kasnije, kada u pregovore s Turcima odlazi fra Ilijin rođak i nastavljač fra Andrija budući da su Mlečani postavili ultimatum identičan onome kakav su prije pola stoljeća Turci stavili pred Mlečane.

Ovakvim izborom događaja Šehović je na fabularnoj razini proveo ideju cikličnosti povijesti, vječnog vraćanja istoga zbog nemogućnosti učenja iz prošloga.

Motiv ponavljanja vidljiv je i u komentarima pripovjedača koji u okviru tematsko-idejnoga sloja romana zapravo funkcioniraju kao moralizatorski iskazi, primjerice:

„Događali su se takvi zločini u Bosni i još se događaju...“ (173).

Po pitanju iskaza o povijesti koja više nema ulogu učiteljice života, u Ilijasbegovićima je znakovit dijalog u kojem protagonist trećega dijela (Begovina) Ilijas-beg i njegov prijatelj/kroničar fra Ivan Lovrenović suprotstavljaju mišljenja:

„'Sve su to zablude, nude nam samo nove oblike naše nesreće', rekao je jednom Ilijasbeg, a kad se fra Ivan pozva na povijest 'magistram vitae', prijatelj mu uzvrati doslovce da je takozvana učiteljica života krcata ugodnim lažima i neodoljivim zabludama.“ (412)

Među svim Šehovićevim povijesnim romanima upravo saga o trebinjskoj obitelji Ilijasbegovićima najzornije demonstrira način na koji povijest predstavlja tek „,vježbanje života“" (Fabrio).

Za petoknjižje Ilijasbegovići:Cronica travuniana može se upotrijebiti podžanrovska etiketa koju je Julijana Matanović dala Fabrijevoj trilogiji: riječ je o „povijesno-obiteljskim romanima“ kao „modelu novopovijesne varijante“ (1998: 281). U takvim je romanima „puno važnije prikazivanje moći koju povijest, uvijek na isti način, i s istim učincima, demonstrira na svakoj grani generacijskog stabla, nego detaljno praćenje međusobnih obiteljskih odnosa“ (isto) ${ }^{19}$.

\footnotetext{
${ }^{19}$ Uz Fabrijeve romane, Julijana Matanović (1998: 281 - 282) kao primjere obiteljsko-povijesnoga modela novopovijesne varijante navodi Dom, sve dalji (1977.) Petka Vojnića Purčara i Legendu i zbilju (1993.) Lijerke Damjanović Pintar.
} 
Povijesnu ponovljivost Šehović prezentira fabularnom izgradnjom gubitničkoga položaja svakoga od protagonista loze Ilijasbegovića:

Ilijas-bega, kapetana trebinjskoga iz 17. st.; Hasan-bega iz 18. st.; Ilijas-bega (suton AustroUgarske Monarhije - vrijeme Prvoga svjetskog rata); Enver-bega (događanja vezana uz Drugi svjetski rat) i Ilijas-bega (razdoblje od Drugog svjetskog rata do rata 90-ih u Hrvatskoj i Bosni).

Ratni vrtlozi u širokom razdoblju od 17. stoljeća do naših dana odveli su članove Ilijasbegovića na različite ideološke strane, ali uvijek s gubitništvom kao zajedničkim nazivnikom.

Uz nazive likova (tri Ilijas-bega), na povijesnu ponovljivost najslikovitije upućuju gotovo pa identični prikazi gubitničkoga položaja tijela predstavnika pojedinih generacija obitelji Ilijasbegovića tijekom stoljeća - sjede očajni s laktovima zarivenima u koljena i prstima u kosi pitajući se zašto se Ilijasbegovićima uvijek događa isto. ${ }^{20}$

$\mathrm{Na}$ tome je tragu značajno jukstapozicijski razmotriti sljedeće ulomke iz romana (dijelove istaknula D. M. L.):

a) Hasan-beg (Inšallah - 2. dio Ilijasbegovića) „A gdje je on to stigao? Tu, zapravo, nigdje, sjedi na postelji, bolesnički presamićen, s laktovima ukucanim u natkoljenice i prstima očajnički zarivenim u kosu, baš kao na slici onog zarobljenog slikara špijuna. A takvu sliku on je davno vidio, zapravo zamislio u fra Matijinim opisima njegova oca kad se našao u prilici kao on sada. Zašto se te prilike ponavljaju; baš njima, Ilijasbegovićima?““(237)

b) Ilijas-beg (Begovina - 3. dio Ilijasbegovića) „Bojnik Ilijas-beg sjedio je na klimavoj klupi očajan, sa zarivenim prstima u kosi, kao njegov pradjed na uljanoj slici u velikom salonu Begovine. Zločin u selu silno ga je potresao.“(396)

c) Ilijasov otac Enver-beg (Dubrovački intermezzo - 4. dio Ilijasbegovića) „Sjeo je, kaže, na neki hrastov panj, malo dalje od puta, poviše šumske vododerine, 'pravog mjesta za smaknuća', kaže, ne treba rake kopati, nego samo nasuti zemlju i kamenje. Sjedio je, nastavi, nadlaktivši se rukama na koljena i zarivši prste u kosu.

\footnotetext{
${ }^{20} \mathrm{O}$ slikarskim portretima i fotografijama članova obitelji Ilijasbegovića više u dijelu rada koji se bavi diskurzivnom klasifikacijom dokumenata svjedočenja u Šehovićevim povijesnim romanima (,Slikovni zapis“).
} 
Husein mu je rekao: 'Nije pravo beže. Zašto baš tebe?' Otac je pogodio što misli i sasvim mirno rekao: 'I moj babo je nevin odgovarao za zločine drugih.'“ (657)

d) Ilijas (Od Mostara do Den Haaga - 5. dio Ilijasbegovića) „Možda to oni već i znaju, uvjeravao je Marko samoga sebe, dok je prijatelj sjedio na zidiću kraj njega s prstima zarivenim u kosu, oborena pogleda, šutljiv i nepomičan kao kip, kao onaj miralaj Hasan-beg na uljanom portretu, kao i njegov otac na Bleiburgu, kako Ilijasbegovići oduvijek izgledaju kada se nađu pred nepreskočivim zidom svojeg kismeta. “(939)

U svjetlu prethodnih citata iz Šehovićevih Ilijasbegovića, istovjetnost sudbina podcrtana je fizionomijom pripadnika različitih generacija i u Vježbanju života (1985.) Nedjeljka Fabrija, na primjeru likova Jakova Despota i njegova unuka Vjenceslava Despota. Opisujući Jakovljevo upalo lice i uplašen, isprazan pogled, pripovjedač proleptički napominje:

„(Isti takav pogled, isto lice, imat će i njegov unuk, Vjenceslav, sedamdesetak godina kasnije, na onom vicinalnom parobrodiću kojim će se, nakon završetka Drugoga svjetskog rata, vratiti u grad.)“(2005: 142 - 143)

U daljnjem će se pripovijedanju kod Fabrija opet naglasiti odnos fizionomije pretka i potomka, samo je sada pripovjedačev pogled analeptički, u vidu flashbacka:

„(Isti takav pogled, isto lice imao je i njegov djed Jakov, prije sedamdesetak godina. Njegovo postojanje Vjenceslav jedva pamti...)“(2005: 199)

Za ocrtavanje cikličnosti u Ilijasbegovićima znakovit je i motiv sata (simbolika kružnoga kretanja vremena) koji se prenosi s generacije na generaciju. Sat Ilijas-bega iz Begovine prenosi se na sina Enver-bega, koji ga prije pogubljenja na Bleiburgu predaje vozaču Huseinu uz molbu da ga dostavi sinu Ilijasu. Ilijas će prije čina samoubojstva sat predati prijatelju Marku kako bi dospio do najmlađeg Ilijasbegovića - Enka, Ilijasova rođaka. 
Vidljivo je da se u svim Šehovićevim povijesnim romanima povijest ne prezentira kao teleološki proces koji podrazumijeva progres, odnosno ideju povijesnoga napretka, nego kao neteleološki, u smislu reverzibilnosti, vječnog vraćanja istoga (v. Milanja 1994: 1082). Reverzibilnost povijesnih procesa uvijek donosi ponovni poraz za pojedinačnu egzistenciju, stoga se novopovijesni romani, uključujući ove Šehovićeve, redovito mogu iščitavati kao alegorične, parabolične priče o odnosu politike i pojedinca (usp. Milanja 1994: 1085; Jelčić 2004: 540; Nemec 2003: 268, 282; Pavličić 1995: 123).

U nastavku će se Šehovićevi romani razmotriti s obzirom na formalne gradbene elemente kao tekstualne indikatore žanra: naslov i podnaslov, predgovorne/pogovorne bilješke te prvu rečenicu (prema Matanović 1998: 263 - 318).

Ni jedan od naslova romana Šehovićeve trilogije ne upućuje čitatelja na povijesna zbivanja ni povijesne likove, a što je bio čest slučaj u povijesnoj varijanti. Naslovi su konativne prirode pa čitatelj iz samog naslova ne može pretpostaviti da u ruci drži povijesni roman.

Gorak okus duše upućuje na unutrašnje stanje protagonista (posebno vidljivo u karakterizaciji Vincenca i Vicka), na osjećaj gorčine u likovima, gorčine koja proizlazi iz beznađa i rušenja svih ideala. Naslov je vezan i za konvenciju pronađenoga zapisa budući da se odnosi na jedan od stihova ,pronađene“ Vickove pjesničke zbirke:

„Samo očajanje, strava noći, / obuzetost nečim i gorak okus duše“ (GOD: 151, istaknula D. M. L.)

Zanimljivo je pripomenuti kako se motiv ,gorčine duše“ intertekstualno naslanja i na biblijsku Knjigu o Jobu, a čiji su stihovi uklopljeni u motto 10. poglavlja romana Oslobađanje đavola:

„U tjeskobi duha govorit ću sada, / u gorčini duše ja ću zajecati.“ (OĐ: 61, istaknula D. M. L.)

Naslov Oslobađanje đavola aludira na nekoliko sastavnica romana. Prije svega, riječ je o tumačenju velikog dubrovačkog potresa iz 1667. godine kršćanskom ideologijom: potres percipiran kao akt oslobađanja đavola zazidanoga u temeljima grada, a što će nastupiti kao Božja kazna za ljudske grijehe. Kršćanska ideologija u romanu, suprotstavljena znanstvenoj slici svijeta (potres kao prirodna pojava), intertekstualno se naslanja na biblijski zapis, što je 
naznačeno u 3. poglavlju romana. Tako se motivu odvezanoga đavla ovjera pronalazi $u$ Ivanovu Otkrivenju: „Poslije tog ima bit odvezan kratko vrijeme“ (ОĐ: 19).

Osim na sam potres, naslov se romana u prenesenome značenju odnosi i na oslobađanje zla/đavla u ljudima, vidljivo posebno u epizodama koje prikazuju ponašanje ljudi nakon potresa:

„To je taj đavo što nas obuzme i pamet nam uze pa postasmo gori od svake živine zemaljske. I to bijaše tek početak đavolje orgije u kojoj bestraga ishlapješe posljednje kapi ljudske svijesti i savjesti.“(OĐ: 162).

Naposljetku, Oslobađanje đavola naslov je inkriminirane poeme jednoga od likova - pjesnika i filozofa fra Mavra Sarake - koja u roman nije citatno ugrađena, već se njezin sadržaj kazuje i komentira s pozicije pripovjedača.

Poput naslova prethodnih romana, i Uvod $u$ tvrđavu odvodi do konvencije pronađenoga zapisa.

Pepo Mitrovich, jedan od protagonista, nakon logorskih mučenja piše dramu pod imenom Tvrđava s podnaslovom Biblija za nevjernike, a koja naknadno dolazi u ruke drugom liku, njegovu najboljem prijatelju Luki Božidareviću. O recepciji Tvrđave izvještava Pepov unuk Raul Mitrovich, sastavljač kratke kronike koja čini sam kraj romana.

U tome smislu čitav roman funkcionira kao tekstualna podloga (uvod) za čitanje nekog drugog teksta: uvod u Tvrđavu ${ }^{21}$.

Vidljivo je da podnaslov (kao gradbeni element) ovoga Šehovićeva romana nema onu funkciju koju su imali romani povijesne varijante jer sam podnaslov ne uključuje žanrovski indikator (prošlost, historija ili povijest) ni vremenske i prostorne odrednice (usp. Matanović 1998: 270 - 272).

Romani Oslobađanje đavola: Kronika i Ilijasbegovići: Cronica travuniana, s druge strane, donekle su podnaslovljeni $\mathrm{u}$ duhu povijesne varijante s obzirom da upućuju na kronikalnost - bilježenje događaja vremenskim slijedom.

\footnotetext{
${ }^{21} \mathrm{~S}$ obzirom da je Tvrđava naslov fiktivne drame na koju se oslanja roman, naslov bi ovoga Šehovićeva romana, u skladu s pravopisom, valjalo pisati Uvod $u$ Tvrđavu (a ne Uvod u tvrđavu). Na taj bi način i iz samoga naslova bilo vidljivo oslanjanje jednoga teksta na drugi tekst.
} 
Podnaslov Cronica travuniana, kao i naslov romana Prokleta ergela, intertekstualno se naslanjaju na književno stvaralaštvo Ive Andrića, upućujući tako, i na ovaj način, na uronjenost svakoga teksta u matricu ostalih tekstova.

Cronica travuniana referira se na Andrićev roman Travnička hronika. Pri tome je zanimljivo spomenuti kako paralela nije ostvarena na očitoj razini - na Travniku kao mjestu fabularnoga razvoja. Naime, Šehovićev roman spacijalno obuhvaća ponajviše relaciju Trebinje Dubrovnik.

Kao i Andrića u Travničkoj hronici, i Šehovića u Ilijasbegovićima zanimaju granična područja, u smislu prostora susreta različitih (Istok i Zapad), kao i problematika odraza velikih povijesnih previranja i izmjena ideologija na generacije malih, običnih ljudi, posebno onih koji se ne uklapaju u kalupe dviju suprotstavljenih strana. Zahvaćajući ljudske sudbine kronološki, i Andrić i Šehović upućuju na ponovljivost situacija i neizbježno gubitništvo kao rezultat povijesnih gibanja.

Što se tiče samih Ilijasbegovića, nije riječ o velikom povijesnom imenu kakvo bi se našlo na koricama povijesnoga romana tradicionalnoga tipa. Naime, podatke o Ilijasbegovićima uzaludno je tražiti u službenim spisima velikih državnih arhiva. ${ }^{22}$

Andrićeva Prokleta avlija i Šehovićeva Prokleta ergela upućuju na „prokletost““ uskih, ograđenih prostora (carigradski zatvor / napuštena ergela na kliškoj tvrđavi koja služi kao mučilište-logor onih drugih i drugačijih) koje je preuzela figura stradavanja i traume te upitna mogućnost interkulturnoga dijaloga. Ovi prostori funkcioniraju kao svojevrstan pars pro toto: predstavljaju književnu imaginaciju Bosne, ali i svijeta u cijelosti.

Šehovićeva ergela i Andrićeva avlija mogu se promatrati i kao reprezentativni primjeri Foucaultovih heterotopija kao „drugih mjesta“/"protumjesta“, i to tzv. heterotopija otklona ${ }^{23}$, u koje prvenstveno spadaju prostori različitih tipova zatvora (uz prihvatilišta, klinike, staračke domove i sl.). Riječ je o mjestima koja, za razliku od utopija kao nerealnih prostora, predstavljaju realna mjesta „koja se mogu iznaći unutar kulture, istodobno kao predstavljena, osporena i preokrenuta, mjesta koja su izvan svih mjesta“, a koja „nastanjuju pojedinci čije ponašanje odstupa od uobičajenog prosjeka ili norme “. ${ }^{24}$

\footnotetext{
${ }^{22}$ Sam Feđa Šehović napominje kako je riječ o kronici jedne hercegovačke obitelji, s tim da u Hercegovini, posebno u Trebinju, gdje je i smjestio Ilijasbegoviće, takvo prezime nikad nije postojalo. Spominje da je poznavao jednoga Ilijas-bega iz loze Resulbegovića, prema čijem je imenu izmislio Ilijasbegoviće. (Feđa Šehović - Ilijasbegovići: https://www.jutarnji.hr/arhiva/feda-sehovic-ilijasbegovici/3221459/(17. 3. 2018.)

${ }^{23}$ Vidi: Michel Foucault, O drugim prostorima: http://pescanik.net/o-drugim-prostorima/ (22. 3. 2018.)

${ }^{24}$ Vidi prethodu fusnotu.
} 
Izdvojenost i marginaliziranost heterotopija, odnosno disidenstvo pojedinaca koji nastanjuju prostore pružaju priliku (i) za stanovitu (de)konstrukciju ideoloških i identitetskih obrazaca.

Gorak okus duše nema podnaslov, ali jedini je roman trilogije opremljen predgovorom, koji ukazuje na jedan od načina predstavljanja dokumenta u novopovijesnom romanu: dokument kao „paracitat u situaciji kad simulira predgovorne bilješke i obraćanja štiocu“ (Matanović 2003: $130-131)^{25}$.

Predgovor potpisuje fiktivni Autor koji je, u potrazi za objašnjenjem imena sela Bezbozi, naišao na različite zapise i kazivanja. Najviše mu je pozornosti privukao rukopis Mavra S. iz 1620. godine.

Iako je već na prvi pogled jasno kako pozivanjem na pronađeni rukopis predgovor ima funkciju ukazivanja čitatelju na provjerljivost, a time i istinitost iznesenog (funkcija predgovornih bilježaka povijesne varijente), takvu početnu intenciju ruši činjenica da je riječ o paracitatu s obzirom da pronađeni rukopis iz romana ne korespondira nekom stvarnom, provjerljivom predlošku.

Čak i ako se stavi sa strane fiktivnu /nefiktivnu prirodu dokumenata, razlika povijesne i novopovijesne varijante u ovom slučaju uspostavlja se prilikom izbora vrste građe na koju se poziva u predgovoru. Šehovićev potpisnik predgovora ne oslanja se na velike, službeno potvrđene povijesne dokumente, već na privatne zapise malih pojedinaca. Načelo objektivnosti zamijenjeno je subjektivnošću u pristupu povijesnim zbivanjima. U tom smislu valja naglasiti i važnost zbirke pjesama jednoga od protagonista romana (Vicko) kao dijela rukopisne građe.

Ono što predgovor romana Gorak okus duše povezuje s predgovorima povijesne varijante jest isticanje analogije:

„Na osnovu spomenute rukopisne građe odlučih se napisati roman o sudbini fra Vincenca i njegova neputa Vicka, uvjeren da njihova muka ne pripada samo davnom šesnaestom stoljeću, kao što je zasigurno mislio i moj prethodnik prognanik fra Mavro S. pišući svoju Kroniku...“(GOD: 10)

\footnotetext{
${ }^{25}$ Uz spomenuti način, Matanović upućuje na predstavljanje dokumenta u obliku slabog dokumenta unutar samoga djela te u obliku pravoga/jakoga dokumenta koji je pretrpio određenu autorovu intervenciju (2003: 130 138).
} 
Očito je da je Šenoino geslo izneseno u Vijencu još 1874. kako „u historičkom romanu moraš analogijom između prošlosti i sadašnjosti narod dovesti do spoznaje samog sebe“ $(443)^{26}$ aktualno i u novopovijesnoj varijanti.

„U povijesnoj varijanti hrvatskoga povijesnog romana česti su primjeri određivanja povijesnog vremena inkoativnom rečenicom romana. Ona može biti izgovorena pozicijom autorskoga pripovjedača i pozicijom svjedoka događaja.“ (Matanović 1998: 272).

$\mathrm{Na}$ tragu prethodnoga može se utvrditi da prva rečenica Oslobađanja đavola donosi spomenute vremenske informante pozicijom autorskoga pripovjedača:

„Znanost bilježi da su velikoj trešnji u Dubrovniku, koja se dogodila 6. travnja 1667. godine, prethodila dva katastrofalna potresa nadprosječne jačine.“ (OĐ: 7)

I prva rečenica Proklete ergele donosi dio povijesne pozadine romana s naznakom godine kojom počinje fabularni razvoj:

„Odlukom provincijalata bosanskih franjevaca krajem 1595. godine, fra Ilija je trebao početkom sljedeće godine otputovati u Rim s čvrstom namjerom da okonča duge $\mathrm{i}$ ozbiljne nesuglasice između bosanskih franjevaca i generaliteta u Rimu.“(PE: 9)

Uvodna rečenica Gorkoga okusa duše ne predstavlja čitatelju precizne vremenske odrednice radnje (u predgovoru je naglašeno kako je riječ o događajima iz 16. st. o kojima se govori na osnovu fra Mavrova rukopisa iz 1620. godine) niti je usmjerena na velike povijesne događaje:

„Onoga dana kada je straža došla u samostan i naredila mu da u 'ime zakona' pođe s njima, fra Vincenco je slutio zlo, ali ne toliko koliko će zaista doživjeti.“(GOD: 11)

Pripovjedač najavljuje tragičnu sudbinu fra Vincenca kao malog pojedinca naglašavajući proleptičkim komentarom (,fra Vincenco je slutio zlo, ali ne toliko koliko će zaista doživjeti“") neočekivane razmjere tragičnosti.

\footnotetext{
${ }^{26}$ Vidi fusnotu br. 14
} 
Uvod u tvrđavu započinje rečenicom u potpunosti netipičnom za bilo koju varijantu povijesnoga romana, a posebno onu povijesnu:

„Iznova nastavljamo ljubavnu igru, sve snažnijim zagrljajima i sve duljim poljupcima, dok se priljubljena gola tijela lelujavo povijaju u toplom bezdanu užitka.“(UUT: 7)

Rečenica je izgovorena pozicijom svjedoka koji u daljnjem tekstu govori o svome uhićenju u Berlinu, a što čitatelja prethodnih romana trilogije može odvesti i do prve rečenice Gorkoga okusa duše, koja govori o pritvaranju fra Vincenca, ali s pozicije autorskoga pripovjedača. Motiv pritvaranja/uhićenja/kažnjavanja prisutan je i u Oslobađanju đavola.

Ugroženost pojedinca pod mehanizmima vlasti kao stalno mjesto Šehovićevih romana bit će problematizirano u nastavku rada (poglavlje o svjedocima).

Ciklus o Ilijasbegovićima započinje rečenicom koja naglašava poziciju svjedoka: „I on mi tada reče: 'Piši Matija, piši.'““ (I: 7)

Fra Matija postaje kroničar, a time i svjedok života Ilijas-bega, trebinjskoga bega iz 17. stoljeća. Ovakav će odnos, temeljen na simbiozi stradalnika povijesnoga procesa i njegova svjedoka, biti ostvaren u svim dijelovima petoknjižja Ilijasbegovići.

Iako prva rečenica romana ne daje čitatelju nikakve vremenske signale, tu će zadaću preuzeti prva fusnota romana, kojom se navodi godina objave fra Matijinih rukopisa (1696.).

Kao što i podnaslov sage upućuje, događaji su, nakon prvih rečenica Ilijas-begove ispovijedi fra Matiji, zahvaćeni kronološki, pri čemu se kontinuirano navode precizne vremenske oznake, ponekad s naznačenim paralelizmom kršćanskoga i islamskoga kalendara (dio Inšallah). ${ }^{27}$

Iz prethodnoga je izlaganja vidljivo da se Šehovićevi povijesni romani (Gorak okus duše, Oslobađanje đavola: Kronika, Uvod u tvrđavu: Biblija za nevjernike, Ilijasbegovići: Cronica travuniana, Prokleta ergela) uklapaju u matricu novopovijesnih romana prije svega po autorovu prikazu povijesti kao reverzibilne činjenice, kruga vječne patnje, beznađa $\mathrm{i}$ poraza za male sudionike velike povijesti.

\footnotetext{
${ }^{27}$ Primjeri: „na izmaku zime 1692.“(20); „29. travnja 1693،“(71); ,,sumorna i kišna jesen 1114. godine po Hidžri (1693. poslije Krista) (96); „Proljeće je 1155. godine po Hidžri (1734. poslije Krista) (303); ,„početkom posljednjeg tjedna 1899. godine“ (315); ,,početkom kolovoza godine 1940.“(513); „,dva mjeseca poslije Dana armije, 1970.“(825); „,sredinom ljeta 1993.“(919); „,uoči prve godine trećega tisućljeća“ (1002)...
} 
Sudbine likova na stranicama trilogije ukazuju na povijest ne kao na ,uzor i preporuku, nego zastrašujući primjer, opomenu“ (Žmegač 1994: 86), „povijest je zbilja kakva ne bi trebala biti“" (isto: 87 ). ${ }^{28}$

I formalni gradbeni elementi (naslov, podnaslov, prva rečenica, predgovor) uglavnom se mogu promatrati u okviru novopovijesne varijante. Izuzetak po tome pitanju predstavljaju Oslobađanje đavola i Ilijasbegovići - podnaslovljeni kao kronika.

Prva rečenica Oslobađanja đavola i Proklete ergele (precizni vremenski i prostorni informanti, spominjanje potresa odnosno sukoba bosanskih franjevaca s vrhuškom u Rimu kao povijesne pozadine) donosi karakteristike povijesne varijante žanra hrvatskoga povijesnog romana.

Iako je Gorak okus duše opremljen predgovorom, riječ je o fiktivnome zapisu, a ne stvarnom, dokumentarističkom predlošku tipičnom za šenoinski povijesni roman.

I razina likova (izbor likova i njihova karakterizacija) simptomatična je za određivanje pripadnosti novopovijesnoj varijanti.

U Šehovića „nosivi likovi nisu povijesno potvrđene osobe (baš kao ni Fabrijevi), ali su zato sudionici tragičnih političkih previranja o kojima ćemo, znanstvenim fokusom u koji Šehović duboko sumnja, naći činjenične potvrde“ (Matanović 1998: 295 - 296).

Poglavlje ovoga rada pod nazivom „Svjedoci“ (dio „Svojstva likova svjedoka i njihova naratološka izgradnja“) pokazat će u kojem se stupnju Šehovićevi likovi svjedoka uklapaju u novopovijesnu matricu.

Kako je već prethodno spominjano, istaknutu dodirnu točku povijesne i novopovijesne varijante predstavlja stvaranje analogija između prošlog i sadašnjeg (a time i prognoza budućeg). Osim toga, i romane novopovijesne varijante, kao i one povijesne varijante,

\footnotetext{
${ }^{28}$ U kontekstu odnosa prema povijesti zanimljivo je na ovome mjestu uputiti i na neka relativno nova književnopovijesna/književnoteorijska promišljanja. Miranda Levanat-Peričić (2015) tako uočava „protupovijesnu retoriku“ u hrvatskim novomilenijskim romanima (npr. Povijest moje obitelji od 1941 do 1991, $i$ nakon Ivane Sajko, Adio kauboju Olje Savičević Ivančević, Hotel Zagorje Ivane Simić Bodrožić, Kalendar Maja Zorana Ferića, Črna mati zemla Kristiana Novaka).

Iako naglašava kako navedeni romani nisu niti povijesni niti novopovijesni budući da im polazište nije historiografska građa, autorica uočava kako se „povijesna tema u suvremenim romanima desetih godina novog milenija javlja u kontekstu koji je blizak formuli historiografske metafikcije kako je vidi Tatjana Jukić - ona je naglašeno subverzivna u odnosu na ustaljenu političku i povijesnu naraciju, a njezina se moć temelji na „parodiji, pastišu, plagijatu, otvorenom falsificiranju, razotkrivanju i dekonstrukciji svega što teži totalizaciji“ (Jukić 2003: 135)“ (Levanat-Peričić 2015: 295).

„U novom protupovijesnom hrvatskom romanu, povijest se ne može ni odbaciti ni potisnuti ni nadopisati, ona više nije funkcionalna nego devastirajuća poput prokletstva roda u grčkoj tragediji; bez krajeva i početaka u mitskom obnavljanju vremena, u kojem je svaki početak ujedno i kraj, a svako se 'naprijed' spotakne na istim mjestima." (isto: 305 )
} 
obilježava moralističan $\operatorname{ton}^{29}$; samo što se taj ton više ne ostvaruje $u$ okviru monumentalističkih i antikvarnih zanosa (usp. Nietzsche - prethodne napomene) prilikom iznošenja povijesne priče. Sada na snagu stupa kritički stav prema povijesti, povijesti što je percipirana tek kao ,jalovost, ludost i smrt“ (Fabrio) ${ }^{30}$.

\footnotetext{
${ }^{29}$ Usp. npr.

„Spomenuti romani (autor misli na romane Ivana Aralice, Feđe Šehovića i Nedjeljka Fabrija, op. D. M. L. ) po svojoj općoj impostaciji, oblikovnoj i tematskoj, dopuštaju zaključak da romaneskni odgovor na iskustva prošlosti i današnjice nije projiciranje apsurdnoga svijeta, nego odgovor koji ima - u najširem smislu, bez ideoloških natruha - moralistički karakter. (...) Iza mračne slike povijesne prošlosti nalaze se stanovite predodžbe oprečnoga značaja, to jest vrijednosni postulati etičke naravi utemeljeni u svjetonazornim tradicijama...“ (Žmegač 1991: 84)

„No, valja reći da i u Aralice i u Fabrija i u Šehovića glede ponuđene slike povijesti i funkcioniranja historiografskoga sloja, koji nimalo nije uzorit, romaneskna svijest osuđuje takovrsnu povijest.“ Na osnovi toga Žmegač zaključuje da je za hrvatski novopovijesni roman karakterističan patos shvaćen kao „duhovni stav u ophođenju s književnosti, a posebno povijesti...““(Žmegač 1991: 71)

„Međutim, kako sam više puta naglasio, radije bih istaknuo strukturu moralnosti koja nije samo implicirana, nego je i svojevrsni generativni kod romana.“(Milanja 1994: 1088)

„Ostala je, u nekih pisaca (misli na pisce suvremenih hrvatskih povijesnih romana, op. D. M. L.), i snažna nota didaktičnosti, prosvjetiteljskog žara i moralizma. Bezumlju povijesti najčešće je, kao 'protuteža', suprotstavljena etika pojedinca ili etnosa: moralizam je i dalje ostao duboko ukorijenjen u našemu povijesnom romanu." (Nemec 2003: 268)

${ }^{30}$ „Ali nisam ja zvao povijest, nisam ja izmislio povijest! Pa ona se sama kao suh čičak, nametljivo i do krvi ranjivo lijepila o moje pripovijedanje! Kada god sam započinjao priču, a kroz nju je, kao onaj grah iz bajke, brže-bolje prorastao drač i korov povijesti: jalovost, ludost, smrt. Zar je povijest nešto drugo? Zar sam sve ovo zaista ja izmislio?"“(Fabrio 2005: 222, istaknula D. M. L. )
} 


\section{SVJEDOČENJE, SVJEDOK: TEORIJSKA KONTEKSTUALIZACIJA}

Pojmovi svjedočenje i svjedok višesmjernoga su etimološkoga određenja i polidiskurzivne primjene (pravo, historiografija, folkloristika, psihoterapija, teologija, književnost...).

Teološka vizura svjedočenja, u kontekstu kršćanstva, vezana je uz ideju vjere kao modusa svjedočenja: Isusov život i propovijedanje kao svjedočenje Oca, djelovanje apostola i svih kršćana kao strategija svjedočenja vjere...(v. Ančić 1982).

U psihoterapijskome okružju svjedočenje zadobiva intimnu ispovjednu funkciju. Riječ je o pokušaju pripovijedanja, konstrukcije priče, odnosno kauzalnoga zahvaćanja traumatskoga doživljaja i njegova smještanja u osobnu povijest pacijenta, temeljem čega se može govoriti o terapijskoj moći pričanja/svjedočenja stanovite subjektivne istine (v. Herman 1996).

Svjedočenje je u pravnome sustavu percipirano kao ,,autentična verbalna konstrukcija prošlog događaja čiji narativni zaplet pokreće načelo krivnje izvršitelja. Jer bez načela krivnje nema okrivljenog (nulla poena sine culpa), a time ni ostalih sudionika pravnog procesa utvrđivanja krivnje ili nevinosti osumnjičenog“ (Jambrešić Kirin 1999: 31). U tome se smislu uvijek može/mora svjedočiti za nekoga / protiv nekoga.

Upitna vjerodostojnost svjedočenja na sudu podcrtana je konvencionalnom uporabom prisege svjedoka, a upravo je ,prosuđivanje vjerodostojnosti svjedočenja i pouzdanosti svjedoka područje najvećeg podudaranja suca i povjesničara“ (Jambrešić Kirin 1999: 32).

Pri spomenu povjesničara i povijesti, valja uputiti na još neke terminološke nijanse. Naime, u ovome će se radu uzeti u obzir distinkcija između svjedočanstva i svjedočenja na tragu promišljanja gore spomenute znanstvenice Renate Jambrešić Kirin. Ova autorica u svojoj doktorskoj disertaciji ${ }^{31}$ svjedočanstvo povezuje s historiografsko-dokumentarističkim izričajem, a svjedočenje s književnim, pri čemu svjedočenje promatra u okviru onoga što se u književnoznanstvenim tekstovima najčešće naziva testimonijalna literatura / književnost svjedočenja, pa čak i općenito testimonijalni tekstovi / tekstovi svjedočenja, testimonijalna produkcija i sl.:

„Svjedok koji piše unutar prvog modela rijetko ili bojažljivo iskazuje sumnju u diskurzivni poredak na čijem je vrhu pretpostavljeno kolektivno pamćenje u suglasju

\footnotetext{
${ }^{31}$ Svjedočenja o Domovinskom ratu i izbjeglištvu: književnoteorijski i kulturnoantroploški aspekti (1999.)
} 
sa (zamišljenom sveobuhvatnom) službenom nacionalnom historografijom. On očekuje da će znanstvene analize eksperata potvrditi njegova uvjerenja i razmišljanja, dok pisca literature svjedočenja na pisanje motivira radikalno nemirenje s postojećom praksom predstavljanja, posredovanja i uopćavanja individualnih sudbina kao sudionika kolektivnih zbivanja.“ (85)

Etimologija svjedoka i svjedočenja vezana je uz latinski i grčki jezik.

U latinskome jeziku postoje dva izraza za svjedoka - testis i superstes, pri čemu testis označava „trećeg“, onoga koji se između dvojice postavlja kao treći (najčešće u sudskim i pravnim situacijama općenito), a superstes podrazumijeva preživjeloga, nekoga tko daje svoj iskaz nakon što je preživio neki događaj (usp. Agamben 2008: 12, 105; Derrida 2000: 186). Giorgio Agamben (2008.) povezuje svjedoka s još jednom riječju latinskoga podrijetla autorom:

„auctor pak znači svjedoka zato jer njegovo svjedočenje svagda pretpostavlja nešto djelovanje, stvar ili riječ - što opstoji prije njega, čiju realnost i valjanost treba potvrditi ili zajamčiti“(105 - 106).

$\mathrm{U}$ tome smislu svjedočenje uvijek podrazumijeva autora iskaza, čime je naglašena individualna i jedinstvena priroda samoga akta svjedočenja.

U grčkome jeziku ne postoji ovakva semantička distinkcija kao u latinskome; svjedok je martys, mučenik:

„Prvi su crkveni očevi iz toga izveli izraz martyrium i njime imenovali smrt proganjanih kršćana koji su tako svjedočili svoju vjeru.“(Agamben 2008: 19)

Problematizirajući u svojoj knjizi Duga sjenka prošlosti (2011.) različite aspekte kulturalnoga pamćenja i sjećanja te njihov odnos prema „politici povijesti“, Aleida Assmann je u okviru definiranja osnovnih pojmova jedno od poglavlja posvetila figuri svjedoka (102 113). Imajuću u vidu trodijelnost niza žrtva - počinitelj - svjedok te uzevši u obzir etimološke značajke riječi svjedok, tom je prilikom ukazala na četiri tipa svjedočenja, odnosno četiri tipa svjedoka: svjedok pred sudom, historijski svjedok, religijski svjedok i moralni svjedok.

Svjedoka pred sudom etimološki povezuje s lat. riječju testis (onaj tko je bio prisutan prilikom nekog čina, tko je treći) (103), a historijskoga svjedoka s lat. riječju superstes (onaj koji je preživio) (104); religijski svjedok doveden je u vezu s grčkim izrazom za svjedoka martys, tj. martirom/mučenikom (105); za moralnoga svjedoka napominje kako se formirao 
tek u razdoblju poslije holokausta na podlozi svih triju prethodno spomenutih tipova svjedoka (107).

Za razliku od svjedoka pred sudom i historijskoga svjedoka, čije bi iskaze trebala obilježavati nepristranost budući da njihovo svjedočanstvo ima pravne konzekvence (izvođenje dokaza, presuda), odnosno znanstvene intencije (pisanje povijesti u smislu pokušaja rekonstrukcije prošlih zbivanja), za Assmann religijski i moralni svjedok nikada nisu samo promatrači, oni u sebi sadrže istodobno žrtvu i svjedoka.

Martir-svjedok umire „s vjeroispovjednim svjedočenjem na usnama“ (106) koje će proslijediti sekundarnom svjedoku - martirijumu. Martirijum mučenikovu smrt ,priznaje kao žrtvu (sacrificium) i prenosi je dalje u vidu smislenoga svjedočanstva“ (106).

Na temelju navedenoga može se zaključiti kako je zadatak svjedočenja u slučaju martira i martirijuma osigurati smisao pretrpljenome nasilju i smrti - muka se pretvara u pobjedu.

„Moralni svjedok za razliku od martira ne postaje svjedok zato što umire nego zato što preživljava; kao preživjeli (superstes) on nije sličan samo historijskome svjedoku nego i pristranom religijskom svjedoku koji postaje svjedok svih onih koji nisu preživjeli.“ (107)

Svjedočenje moralnoga svjedoka ne zasniva se na prenošenju neke svete, pozitivne poruke koja se temelji na idealima za koje valja umrijeti:

„U izričitoj suprotnosti s takvom sakrificijelnom semantikom, on otkriva ogroman zločin i javlja o apsolutnome zlu koje je iskusio na vlastitome tijelu.“ (108)

U svjetlu gore spomenutih termina primarnog, odnosno sekundarnoga svjedočenja, tj. položaja same žrtve i svjedoka te žrtve (te dvije instance se u slučaju religijskoga i moralnoga svjedoka stapaju u istome subjektu - podsjeća Assmann), valja uputiti i na mjesto sekundarnoga svjedočenja kod američkoga književnog kritičara i teoretičara Geoffreya Hartmana.

U jednome se od svojih esejističkih radova Hartman (2006: 1 - 8) referirao na Terrenca des Presa i Lawrenca Langera, koji su prvi upotrijebili sintagmu sekundarno svjedočenje kao koncept svjedočenja koji nije ograničen transgeneracijskim prijenosom (isto:1), u smislu da su potomci žrtava (kao primarnih svjedoka) sekundarni svjedoci tih žrtava. 
U slučaju sekundarnoga svjedočenja riječ je o onima koji postaju svjedoci jer su ostali u kontaktu bilo s prvom generacijom svjedoka ili pak s njihovim svjedočenjima, tako da im određeni traumatičan događaj ne predstavlja tek neki prošli događaj, nego nešto što zahtijeva našu konstantnu problematizaciju.

Upravo zbog naglašavanja odgovornosti i dužnosti trajnoga intelektualnog aktivizma prema nečijem svjedočenju Hartman smatra da je od sekundarnoga svjedoka mnogo prihvatljiviji izraz intelektualni svjedok. Upravo intelektualci, a posebice umjetnici, obilježeni su dužnošću da umjetničkim vidom objave (isto: 6) svjedoče za svjedoke.

Kao uvod u podrobniju ontologiju svjedočenja poslužit će još jedna etimološka napomena. Hrvatska riječ svjedok (posebno u riječi oče-vid) razotkriva indoeuropski korijen *wid-/*weid- u značenju istodobnoga vidjeti i znati (sanskrtska riječ vedah označava „,sveto znanje“) (Jambrešić Kirin 1999: 11).

Tako glagol svjedočiti podrazumijeva i osjetilno iskustvo (vizualno, auditivno...), naglašeno često uvjeravačkim formulama vidio sam to svojim očima / čuo sam to svojim ušima, kao i „diskurzivno, jezično zastupanje vlastitog doživljaja za one koji nisu bili prisutni događaju o kojem se referira na način koji uključuje svojevrsnu ocjenu tog događaja“" (Jambrešić Kirin 2005: 37).

Iako se, u okviru jezične prezentacije, svjedočenje kao iznošenje stanovite priče neminovno veže za postupak pripovijedanja, američka književna teoretičarka Shoshana Felman naglašava apelativnu funkciju svjedočenja ${ }^{32}$ te s tim u vezi upućuje da svjedočenje ne smije biti svedeno tek na problematiku pripovijedanja. Tako, riječima ove autorice, svjedočenje nije jednostavno pripovijedanje, već vrsta obvezivanja pripovijedanjem, „prihvaćanje odgovornosti - govorom - za povijest ili za istinu jednog događaja, za nešto što, po definiciji, nadilazi osobno, imajući opće (neosobne) vrijednosti i posljedice“ (1992a: 204).

I Jacques Derrida naglašava nesvodivost svjedočenja na pripovijedanje „,budući da ono počiva na superiornoj izvantekstovnoj prisutnosti koja u presudnoj mjeri određuje 'sudbinu' iskaza“ (Bekavac 2015: 75).

U kontekstu spomenute „sudbine“ testimonijalnoga iskaza nužno je u nastavku ovoga poglavlja referirati se na teoriju govornih činova Johna Langshawa Austina. Ovaj britanski filozof, koji je ,jezik promatrao kao medij komunikacije s Drugim“(Peternai 2005: 159),

\footnotetext{
32 „to appeal to a community“ (Felman 1992a: 204)
} 
konstativima u smislu istinitih/neistinitih tvrdnji suprotstavlja performative ${ }^{33}$, koji već samom svojom etimologijom (perform - izvoditi) ukazuju da se njima nešto ne opisuje, ne izvještava, ne konstatira (pa ne mogu biti istiniti/lažni), već se njihovim izricanjem izvodi neka radnja (Austin 2014: 2 - 5), odnosno riječ je o „djelovanju riječima“334.

Performative (npr. na krštenju, vjenčanju, imenovanju broda...) promatra kao ilokucijske činove ${ }^{35}$ budući da se izvedba ilokucijskoga čina odnosi na ,izvedbu nekog čina $u$ kazivanju nečeg nasuprot izvedbi čina kazivanja nečeg“" (73, istaknula D. M. L.).

S obzirom na razrede iskaza prema ilokucijskoj snazi, Austin je svjedočenje svrstao i u komisive i u ekspozitive jer svjedočenje podrazumijeva simbiozu preuzimanja obveze ${ }^{36} \mathrm{i}$ postupka izvještavanja, izlaganja, priopćenja (107 - 116).

Za Austina se performativi kao ilokucijski činovi uvijek vezuju uz određene konvencije (87), te je u skladu s tim performativno djelovanje ovisno o ,prikladnim okolnostima“ (10). U tom smislu performativni iskazi (za razliku od konstativnih) umjesto u sferi (ne)istinosti funkcioniraju kao posrećeni/neposrećeni (unhappy) (10).

Derridaovo poimanje performativnih iskaza razlikuje se od Austinovih jer Derrida Austinovu kategoriju (ne)prikladnih „okolnosti“ zamjenjuje „kontekstom“, s tim da nije riječ o istoznačnicama jer „nema konteksta koji se može zatvoriti u sebe“ (Peternai 2005: 35).

Preko kategorije iterabilnosti Derrida upućuje na činjenicu da je svaki jezični znak moguće citirati, čime taj znak izlazi iz jednoga konteksta i proizvodi druge.

Upravo je iterabilnost, dakle, Derridau predstavljala jednu od značajnijih točaka prijepora s Austinom u smislu koncepta performativa. Iterabilnošću je „potkopao razliku između ozbiljnih i neozbiljnjih performativa“ ( Biti 2000a: 232) koju je nametnuo Austin. Austina zanimaju ozbiljni performativi koji djeluju i koji se vežu za „normalne“ okolnosti, dok od svoga fokusa odmiče tzv. neozbiljne performative kojima se ne djeluje nego oponaša jer su vezani za „nametničke“ okolnosti (pozornica, roman i sl. ) (isto). „Derrida naprotiv pokazuje da je oponašanje sam uvjet mogućnosti performativa odnosno pretpostavka njegove djelotvornosti.“(isto)

Tragom posljednjega, Derridaova koncepcija performativa, za razliku od Austinove (ne)posrećenosti, ,inzistira na odgovornosti, etičkoj obvezi koja proizlazi iz rečenog“

\footnotetext{
${ }^{33}$ Austin će u jednom dijelu svoga esejističkoga izlaganja istaknuti kako konstativi i performativi i nisu uvijek lako razlučivi jer je ,vrlo uobičajeno da se ista rečenica u različitim prigodama iskazivanja upotrebljava na oba načina, i performativni i konstativni““ (2014: 49).

${ }^{34}$ J. L. Austin, Kako djelovati riječima (2014.)

${ }^{35}$ Prema Austinu, ,lokucijski čin ima značenje, ilokucijski snagu u kazivanju (in saying) nečega, a perlokucijski čin je postizanje nekih učinaka s kazivanjem (by saying) nečega“" (87, istaknula D. M. L.).

${ }^{36}$ Usp. poimanje svjedočenja kao obveze u S. Felman.
} 
(Peternai 2005: 43). „Svjedočenje tako otvara pitanje odgovornosti koja vrijedi za sva ponavljanja kao govorne činove: odgovorni smo za ono što kažemo čak i ako samo ponovimo riječi drugoga!“" (isto)

Unatoč primjerima pojedinih neslaganja s nekim točkama Austinove koncepcije govornih činova, pod utjecajem Austinova razlikovanja konstativa i performativa u suvremenoj se književnoj znanosti sve češće govori o „peformativnome obratu teorije pripovijedanja“ (v. Biti 2002: 7 - 31) te o ,pripovjednome tekstu kao performativu““(v. Peternai 2005: 101 - 161).

U tome kontekstu i svjedočenje se promatra isključivo kao performativan čin (v. npr. Derrida 2000; Peternai 2005; Bekavac 2015). Pri tome je zanimljivo uputiti na gotovo ekstremnu Derridaovu konstataciju iz jednoga njegova predavanja kako je „sav performativni jezik svjedočenje, i obrnuto; svjedočenje je primjer performativnog govornog čina“" (Peternai 2005: 47).

Poput Shoshane Felman (1992a), i Derrida (2000) ukazuje na neminovnu usmjerenost svakoga svjedočenja nekom adresatu, s tim da Felman inzistira na „odgovornosti“, a Derrida na ,povjerenju“. Naime, adresat svjedoku može samo vjerovati budući da sam nije vidio/doživio ono o čemu svjedok govori (Derrida 2000: 189). Pri tome valja naglasiti da je riječ o dvosmjernome povjerenju, povjerenju koje se razvija kako na relaciji svjedok - adresat, tako i na relaciji adresat- svjedok.

Što u ovom kontekstu znači svjedočiti, tj. biti svjedok(om)?

$\mathrm{S}$ jedne strane postavljen je zahtjev adresatu:

„Ti, moj adresatu, moraš mi vjerovati, jer sam ti se obvezao govoriti istinu...“ (Derrida 2000: 189, istaknula D. M. L.)

Ovaj nalog „moraš mi vjerovati“ ne smije se promatrati u okviru kazivanja nekih provjerljivih znanja i istina, odnosno ne treba ga promatrati na nekoj teoretskoj, već performativnopragmatičkoj razini (v. isto: 189)

Testimonijalni iskaz neodvojiv je od osobe svjedoka, „fokalizacija svjedočenja apsolutno (je) singularna“ (Bekavac 2015: 75), stoga je „dokazivanje krivokletstva i laganja teorijski nemoguće“ (isto), a s tim u skladu „,nitko ne može svjedočiti za svjedoka“ (Derrida 2000: $195)^{37}$.

\footnotetext{
${ }^{37}$ Usp. „There is no witness for the witness. There is never a witness for the witness.“ (Derrida 2000: 195)
} 
Dakle, umjesto verifikaciji, svjedočenje je okrenuto povjerenju. U tome je smislu za Derridu kao odgovor na performativ svjedočenja moguć jedino drugi performativ: „,vjeruj mi“ mora prouzročiti „,vjerujem ti““. ${ }^{38}$

Na temelju iznesenoga, svjedočenje se ukratko može definirati kao ,čin povjerenja bez mogućnosti dokaza“ (Derrida 2000: 195).

Tragom kovanice,,autobiografski ugovor“ Philippea Lejeunea moglo bi se reći da između svjedoka i njegova adresata nastaje neka vrsta „testimonijalnoga ugovora“ : „komunikacijsku situaciju svjedočenja nije moguće realizirati ako iz nje izostane adresat, onaj koji mora čuti svjedočenje“ (v. Zlatar 2004: 165).

Osim iznesenoga zahtjeva za povjerenjem i nemogućnosti verifikacije (u smislu klasične opreke istina/laž), priroda svjedočenja obilježena je i zanimljivom ambivalentnošću: svjedočenje je istodobno potpuno individulano, intimno, jedinstveno, tajno, a s druge strane, kolektivno, opće, javno (usp. Bekavac 2015: 75 - 77).

Svjedočenje ,u svom ishodištu (iskustvu) mora biti apsolutno neponovljivo, dok u svojem odredištu (iskazu) mora biti upravo nužno ponovljivo“" (isto: 76).

Recipijent jedini kontakt sa situacijom o kojoj svjedok kazuje ima upravo preko tog (jezičnoga) iskaza; ,sama 'jezgra' svjedočenja nužno će mu ostati nedostupnom“ (isto : 77) . „Stoga je istina svjedočanstva usko povezana barem s mogućnošću fikcije, krivokletstva i laži. Kad bi se ta mogućnost eliminirala, više ne bi bilo moguće nikakvo svjedočanstvo.“ (Derrida prema Bekavac 2015: 77)

Ukratko, formula svakog svjedočenja mogla bi se uobličiti spojem suprotnih, a ipak međusobno uvjetovanih glagolskih radnji - ,zapečatiti /otpečatiti““(v. Derrida 2000: 180) ${ }^{39}$.

Na kraju još jednom valja podsjetiti kako je naše doba obilježeno značajnom popularizacijom položaja svjedoka i postupka svjedočenja kao polaganja prava na vlastitu priču o povijesnoj istini (v. Jambrešić Kirin 1999: 10 - 30), kako u historiografiji ${ }^{40}$, tako i u književnosti. Primjerice, utjecaj tekstova svjedočenja postao je u recentno doba takav da se može reći kako se „redefinirao književni pejzaž počevši od druge polovine XX. stoljeća, pa se čak govori i o epistemološkoj revoluciji koju su ona izazvala“ (Subašić Thomas 2014: 12),

\footnotetext{
${ }^{38}$ Usp. „To this act of language, to this 'performative' of testimony and declaration, the only possible response, in the night of faith, is another 'performative' consisting of the saying or testing out, sometimes without even saying it, of an 'I believe you.'““ (Derrida 2000: 195)

${ }^{39}$ Usp. ,Signing, sealing, divulging, unsealing.“ (Derrida 2000: 180)

${ }^{40}$ Upućujući na ,protuprosvjetiteljski obrat unutar historiografije 70-ih godina“, Vladimir Biti kao jednu od točaka zaokreta vidi i prebacivanje interesa s arhivske pisane građe na „neobvezatna“ usmena svjedočanstva (2000b: 64).
} 
zbog čega se naše doba sasvim opravdano može etiketirati i kao „doba svjedoka“ (Wieviorka prema Badurina 2010: 191)/,doba svjedočenja“" (Biti 2005).

Naravno, bez obzira na značajnu prisutnost svjedoka i svjedočenja u romanima Feđe Šehovića, nije riječ o djelima testimonijalne književnosti na tragu prethodno spomenutoga. Dok književna znanost više-manje uviđa nesiguran žanrovski smještaj tekstova svjedočenja s obzirom na njihovu faktivno-fiktivnu narav sui generis, čitajući Gorak okus duše, Oslobađanje đavola,Uvod u tvrđavu, petoknjižje Ilijasbegovići i Prokletu ergelu, čitatelj je siguran da u rukama drži (novo)povijesne romane koji literarnim sredstvima problematiziraju poziciju svjedoka i akt svjedočenja u priči o povijesti.

Ne samo na primjeru Šehovićevih romana, nego i onih Ivana Aralice, Nedjeljka Fabrija i Ivana Supeka, Julijana Matanović zaključuje kako i ,,autori novopovijesnih romana posvećuju posebnu pažnju svjedoku događaja i njegovoj točki gledišta“ (2003:141).

Na tome tragu, nastavak će disertacije u književnoteorijskome i književnopovijesnome kontekstu nastojati ukazati na obilježja i efekte svjedočenja kao specifične narativne strategije u povijesnim romanima Feđe Šehovića. 


\section{SVJEDOCI}

\subsection{Pripovjedna pozicija svjedočenja}

U ovome će poglavlju do izražaja doći klasifikacija svjedoka u Šehovićevim povijesnim romanima prema pripovjednoj poziciji svjedočenja (svjedok kao pripovjedač, svjedok nije pripovjedač), uzevši u obzir njihov status u narativu (svjedok kao lik, svjedok nije lik).

Svjedočenje je u svim Šehovićevim romanima povezano s konvencijom pronađenoga rukopisa, kojom se ostvaruje „dvostruka iluzija svjedočenja uz svjedočenje“ (Slabinac 2006: 38). Pronađeni rukopisi najčešće se pojavljuju kao kroničarski zapisi svjedoka događaja, ali i kao poetske tvorevine svjedoka-umjetnika. U romanima se na rukopise upućuje preko fusnota ili/i pozivanja u samom tekstu romana te u predgovornoj bilješci ${ }^{41}$.

Julijana Matanović ukazuje na dva uobičajena načina korištenja svjedočenja u novopovijesnoj varijanti hrvatskoga povijesnog romana:

„U prvom se autorski pripovjedač poziva na svjedoka opisanih događaja, a u drugom junaci preuzimaju narativnu nit i svjedoče; ili prema kazivanju drugih (...) ili iz svoga vlastitog iskustva.“ (2003: 138)

Pripovjedač u fikcionalnim tekstovima predstavlja ,glas koji preuzima odgovornost za pripovjedni iskaz“ (Biti 2000a: 439) te funkcionira isključivo kao „unutartekstna instanca“ (isto).

Gajo Peleš (v. 1999: 61 - 82) među raznim teorijama o pripovjedaču izdvaja onu Franza Stanzela, držeći je najpreglednijom, mada nedostatnom: autorski pripovjedač ne sudjeluje u radnji, nije lik, ali se izravno predstavlja u prvome licu; lik-pripovjedač jedan je od likova, sudjeluje u radnji te pripovijeda u prvome licu; personalno pripovijedanje obuhvaća pripovjedača u trećem licu koji je objektivan i ne sudjeluje u radnji.

\footnotetext{
${ }^{41}$ Diskurzivna klasifikacija dokumenata svjedočenja te njihova inkorporacija u romanesknu strukturu bit će analizirana u narednome poglavlju.
} 
Za potrebe klasifikacije u ovome radu bit će korištena Genettova tipologija pripovjedača jer naglašava i pripovjednu razinu i opseg sudjelovanja u priči (prema Grdešić 2015).

Gérard Genette s obzirom na pripovjednu razinu razlikuje ekstradijegetičkoga od intradijegetičkoga pripovjedača, a s obzirom na opseg sudjelovanja u priči heterodijegetičkoga od homodijegetičkoga pripovjedača.

Ekstradijegetički je pripovjedač ,prvi pripovjedač ili pripovjedač prve razine (vrlo često i jedini pripovjedač u nekom pripovjednom tekstu)“(Grdešić 2015: 94), on je „takoreći, iznad ili superioran u odnosu na priču koju pripovijeda“" (Rimmon-Kenan 1989: 90).

Ovom prilikom valja istaknuti napomenu Maše Grdešić (2015.) kako se genettovske kategorije pripovjedača odnose isključivo na razinu pripovijedanja i opseg sudjelovanja pripovjedača u priči, a ne na lice u kojem se pripovijeda (pripovijedanje u prvom licu, pripovijedanje u trećem licu). Tako, primjerice, ekstradijegetički pripovjedači mogu pripovijedati u prvom ili trećem licu $(94-95){ }^{42}$

„Intradijegetički pripovjedač u pravilu je jedan od likova na (intra)dijegetičkoj razini te pripovijeda tzv. hipodijegetičku razinu.“ (Grdešić 2015: 95) ${ }^{43}$

Bez obzira na razinu pripovijedanja, pripovjedači se razlikuju po opsegu sudjelovanja u priči „pripovjedači mogu biti ili odsutni ili prisutni u priči koju pripovijedaju“( Rimmon- Kenan 1989: 90).

Heterodijegetički je pripovjedač onaj koji ne sudjeluje u priči koju kazuje, a homodijegetički iznosi priču u kojoj je prisutan kao karakter (isto: 90 - 92). Homodijegetički pripovjedači mogu biti pripovjedači-svjedoci koji sudjeluju u radnji, ali ne iznose svoju nego tuđu priču, a mogu i pripovijedati o sebi, odnosno kazivati vlastitu priču, što Genette naziva autodijegezom / autodijegetičkim pripovjedačem (Grdešić 2015: 96).

\footnotetext{
${ }^{42}$ U svome eseju o pripovjednome tekstu u prvom i trećem licu Franz Stanzel (1992.) strukturalne razlike između ove dvije vrste pripovijedanja vidi ponajviše u ,tjelesnosti“ pripovjedača te u motivaciji pripovijedanja. Pripovjedač u prvome licu razlikuje se od autorskoga pripovjedača u trećem licu po „egzistencijalnofizičkom usidrenju svoje pozicije u fikcionalnome svijetu“ (189). Pripovjedač u trećem licu, ni u slučaju autorskoga pripovjedača, ,ne može se povezati s predodžbom određene tjelesnosti““(189), zbog čega on ostaje uvijek izvan fikcionalnoga svijeta likova. Osim toga, pripovjedaču u prvom licu ono što pripovijeda od egzistencijalne je važnosti, dok je motivacija pripovjedaču u trećem licu uvijek literarnoestetska, a nikako egzistencijalna (198). ${ }^{43}$ Može se zamijetiti kako je „,naracija uvijek na višoj pripovjedačkoj razini no priča koju ona pripovijeda. Prema tome, dijegetičku razinu pripovijeda ekstradijegetički pripovjedač, a hipodijegetičku razinu dijegetički (intradijegetički) pripovjedač“(Rimmon - Kenan 1989: 87).
} 


\subsubsection{Svjedok $=$ lik}

\subsubsection{Pozivanje pripovjedača na iskaz svjedoka}

U Gorkome okusu duše, Oslobađanju đavola, Prokletoj ergeli te najvećem dijelu petoknjižja Ilijasbegovići $i^{44}$ ekstradijegetički- heterodijegetički pripovjedač (iznad, superioran priči koju kazuje - ne sudjeluje u priči koju kazuje) poziva se na iskaze svjedoka koji su ujedno i likovi u romanima (glavni ili sporedni likovi).

U Gorkom okusu duše značajno je svjedočenje protagonista romana - fra Vincenca i njegova nećaka don Vicka.

Svjedočenja se u ovome Šehovićevu romanu nadovezuju jedno na drugo tako što proizlaze jedno iz drugoga, nadopunjavajući se i ostvarujući cjelovitu priču koju donosi pripovjedač koji je izvan i iznad te priče: potpisnik Predgovora predstavljen kao Autor (a koji zapravo u romanu funkcionira kao ekstradijegetički-heterodijegetički pripovjedač) poziva se na Kroniku fra Mavra S. ${ }^{45}$; fra Mavro S. na Vickove zapise ${ }^{46}$; Vickovi zapisi nastali su na temelju Vincencova usmenoga kazivanja ${ }^{47}$.

Ovakvim je narativnim rješenjima podcrtano jedno od bitnih svojstava svakoga svjedočenja upućenost na drugoga, a time i reakcija adresata.

Pripovjedač iznosi priču tako da se kontinuirano poziva na kazivanja (najčešće zapise) likova svjedoka. Ovakvim se kazivanjima postiže učinak istinitosti, odnosno riječ je o uvjeravačkim konstrukcijama. Najfrekventnija su pozivanja na Vickove zapise:

„Vickovi zapisi govore“ (17), „kako navodi Vicko u svojim bilješkama“ (49), „kaže u jednoj zabilješci njegov sestrić Vicko“(54), „piše Vicko u svojim bilješkama“ (63), „,napominje Vicko u svojim zapisima O bjekstvu“ (88), „o tome svjedoče pjesme“ (99), „bilježi Vicko“ (135) itd.

Na jednome su mjestu Vickove zabilješke donesene i u 1. osobi, dakle prisutan je direktan citat, s navodnim znakovima:

\footnotetext{
${ }^{44}$ Izuzetak predstavlja posljednji dio trećega dijela Begovina te četvrti dio Dubrovački intermezzo.

45 „Na osnovu spomenute rukopisne građe odlučih se napisati roman...“(GOD: 10)

${ }^{46}$ Vidljivo iz naslova fra Mavrove kronike: „Kronika o porijeklu i imenu sela Bezbozi te o sudbini fra Vincenca i njegova neputa Vicka koji prvi naseli brijeg poviše mora, a čiji unuk u kasnijim godinama svojim preda mi dragocjene spise koji mi poslužiše za sačinit ovo djelo na jeziku domaćem. Anno christianae M D C L." (GOD: 9; istaknula D. M. L.)

${ }^{47}$ „Nakon njihova odlaska, fra Vincenco je šapatom odao nećaku svoju zabrinutost za Mihovila, kao što će mu kasnije, pred smrti ispričati..."(GOD: 66)

„Taj kratki period poboljšanja Vicko je iskoristio da do u tančine čuje Vincencovu priču od njegova utamničenja pa do posljednjeg pokušaja bježanja. Vicko je nastojao sve zapamtiti, misleći da će o tome napisati knjigu, ako se ikada dočepa slobode.“(GOD: 93 - 94; istaknula D. M. L. )
} 
„Tu mi je nešto postalo jasno, piše Vicko u svojim zabilješkama, nešto strašno, što će me kao sjena pratiti cijelog života.“ (63)

U završnom dijelu romana, usmjerenom na Vickov položaj optuženika, unosi se svjedočenje don Ivana. Riječ je o sporednom liku koji je postavljen kao Vickov antagonist.

„Posebno poglavlje u svom pismenom izlaganju dum Ivan je posvetio Vickovom heretičkom zastranjivanju, naglašavajući da je i to djelo njegove sprege s vješticom.“

Roman Gorak okus duše, ne samo svojim početnim dijelom (fiktivnim predgovorom Autora), već i završnim, ostvaruje se paracitatom. Naime, završno, deveto poglavlje romana, sačinjava niz od 25 Vickovih pjesama. Tom je prilikom u tekst romana (na početku devetoga poglavlja) ugrađena fusnota (jedina u romanu) kojom se ukazuje na podrijetlo navedenih pjesama.

Za razliku od Gorkog okusa duše, gdje se pripovjedač učestalo i kontinuirano poziva na spomenuta Vickova svjedočenja (posredništvom rukopisne kronike fra Mavra S.) unutar samog fabularnoga tijeka, u Oslobađanju đavola dominira uporaba fusnote kao narativne strategije prilikom inkorporacije dokumenata.

U kontekstu glavnih likova kao svjedoka velikog dubrovačkog potresa važno je istaknuti pozivanje pripovjedača na rukopis suca Andrije (Andre) Menčetića Zapisi o paklu (De infernis annotationes). Pripovjedač na ovaj rukopis upućuje u prvom poglavlju romana, $\mathrm{i}$ to u samome tekstu romana, te u fusnoti kao paratekstu (termin G. Genetta).

U sljedećim se poglavljima romana kroničarski, „naizgled hladno i nezainteresirano, polazeći od principa odbrojavanja“ (Zima 1989: 253) prikazuju zbivanja u Dubrovniku šest mjeseci prije velikog potresa.

Uz prvo poglavlje romana, fragmenti iz Andrine fiktivne kronike najvećim dijelom ispunjavaju poglavlje (25.) u kojem se opisuje sam tijek potresa.

Andrina sjećanja kombinirana su sa sjećanjima pjesnika fra Mavra Sarake, drugog protagonista Oslobađanja đavola. Fra Mavrovi zapisi funkcioniraju kao dopune i komentari Andrinih zapisa. Tako se, primjerice, pripovjedač prilikom iznošenja slučaja „opsjednutosti““ časne Ore poziva istodobno na Andrina i Mavrova kazivanja:

„Što se zapravo dogodilo s Orom i kako protumačiti to njeno ponašanje? - pitao se gospar Andro mnogo godina kasnije, pišući svoja 'Sjećanja'. Da li se zaista radi o ludilu ili opsjednutosti mišlju o samouništenju, kako je fra Mavro tvrdio (...) Ona, 
govorio je fra Mavro, sigurno nije napastovala mladog fratra da bi zadovoljila svoju uskraćenu žudnju za muškarcem, nego samo zato da bi učinila grijeh, sramotu, da bi dokazala đavola u sebi i sablaznila taj mrski svijet.“(OĐ: 91)

Isprepletenost Andrinih i Mavrovih kazivanja do izražaja dolazi posebno u posljednjem (26.) poglavlju romana, gdje Mavro „intervenira“ u Andrin zapis unoseći u njega i svoj „glas“ (komentari na marginama, prepravljanja, nadopisivanja), čime zapisi ostvaruju neizbježne intertekstualne odnose.

Osim na svjedočenjima glavnih likova Andre i Mavra, Oslobađanje đavola građeno je i na značajnim kazivanjima sporednih likova.

Tumačenje potresa u okviru kršćanske ideologije (potres kao kazna za grijehe) ponajviše je zastupljeno predviđanjima dubrovačkoga fizičara Luke. Luko u maniri proroka „svjedoči unaprijed“. U svojoj raspravi, na koju se upućuje u fusnoti ${ }^{48}$, Luko je, spojivši teologiju i fiziku, prorekao godine budućih potresa u Dubrovniku. Kako je već ranije napomenuto, ovakva gesta figurativno upućuje na percepciju povijesti kao vječnog vraćanja istoga.

Od 21. poglavlja romana u fabularni tijek uključen je lik francuskoga diplomata Hardena, koji je kao dio pratnje nizozemskog rezidenta stigao u Dubrovnik nekoliko dana prije potresa. Na Hardenovo pismo pariškom bankaru Charpentieru upućuje se u fusnoti, a ulomak iz pisma uvršten je u završno (26.) poglavlje romana kao govor svjedoka potresa.

I fragment iz izvještaja o potresu dubrovačkoga nadbiskupa Petra Toresa, napisan na talijanskome, a preveden na hrvatski jezik u fusnoti, umetnut je u završno poglavlje Oslobađanja đavola s istom svrhom - kao pisano svjedočenje očevica tragičnog događaja.

Ekstradijegetički- heterodijegetički pripovjedač u Prokletoj ergeli, sa svrhom iznošenja događaja vezanih uz oslobađanje Klisa od Turaka 1596. i 1648. godine, poziva se na zapise protagonista tih događaja - fra Ilije i fra Andrije, ali i zapise mladoga fra Marka koji piše knjigu inspiriranu mirovnim djelovanjem i patnjom ove dvojice bosanskih franjevaca.

Iskazi spomenutih svjedoka (fra Ilija - fra Andrija - fra Marko) međusobno se nadovezuju jedan na drugi tvoreći efekt ulančavanja, slično kao u Gorkom okusu duše (fra Vincenco - don Vicko - fra Mavro S.).

\footnotetext{
48 „U svojoj kraćoj raspravi 'Aut nihil aut veritas' L. M. de Pozza proriče buduće potrese u gradu Dubrovniku i najbližoj okolici: 1632; 1657; 1667; 1689; 1782; 1800;1821;1838; 1851; 1876; 1898; 1902; 1925; 1939; 1961; $1979 ; 1989 ; 1993 ; 1999 ; 2010 ; 2018$;. Mjesece nije označavao, a godine za koje misli da će se dogoditi katastrofalni potres, dva puta je podvukao. To su: 1667. i 2018.“(OĐ: 12)
} 
Fra Ilijin nedovršeni rukopis o vlastitu životu te usmena kazivanja poslužit će njegovu nastavljaču fra Andriji u kreiranju svojih zapisa pod nazivom $O$ životu i djelu uzora fra Ilije (1648.), dok će se fra Marko Anđelović kao Andrijin nasljednik u svome djelu Život i djelo pravednika fra Andrije i njegova uzora fra Ilije K. (1689.) referirati na Andrijin rukopis.

I na rukopis fra Andrije i fra Marka pripovjedač prvi put upućuje u fusnoti (jedine fusnote u romanu), da bi se na njih, kao i na riječi fra Ilije, kasnije pozivao tijekom samog čina pripovijedanja, npr. „kako zapisa fra Ilija“ (14), „Zapisao je fra Andrija“ (147), ,piše fra Marko“(158)...

Da bi što autentičnije i uvjerljivije dočarao mletački poraz nakon drugog pokušaja (1648. godina) napada na Turke utaborene na kliškoj tvrđavi, pripovjedač se poziva na zapise mletačkog zapovjednika generala Foscola:

„i da nije bilo tako, kako sam zapisa, bacio bi koplje u trnje, pokupio prnje i zauvijek se povukao na očevo imanje nedaleko Venecije“ (60).

Riječ je o rijetkom primjeru Šehovićeva „uključivanja“ stvarnih povijesnih ličnosti u fabulu svojih povijesnih romana. ${ }^{49}$

Stravični zločini koji su počinjeni nad turskim vojnicima na Klisu u tzv. Prokletoj ergeli prezentirani su i ,živom riječju“ samih svjedoka zločina - dočasnika Livnjaka koji je „svojim očima“" gledao mučenje turskih vojnika i civila, kao i bimbaše/zapovjednika Ali-age, jednoga od zarobljenika koji se bijegom spasio iz Proklete ergele. Njihovo usmeno svjedočenje posredovano je intervencijom pripovjedača koji ih donosi pred slušatelja u neizravnoj formi, dakle prepričane u 3 . licu.

I u najvećem dijelu Šehovićeve obimne obiteljske sage Ilijasbegovići (Ilijas-beg, kapetan trebinjski, Inšallah, dio Begovine te Od Mostara do Den Haaga) zapisi i usmeni iskazi svjedoka zastupljeni su preko pozivanja ekstradijegetičkog-heterodijegetičkog pripovjedača.

Naratorska zanimljivost prvoga dijela po imenu Ilijas-beg, kapetan trebinjski leži u činjenici što nakon uvodne rečenice „I on mi tada reče“(7) homodijegetični pripovjedač biva, poslije izravnog citata iz dokumenta, zamijenjen heterodijegetičnim pripovjedačem. Naime, roman započinje izjavom fra Matije, fabularnog aktera i svjedoka Ilijas-begove sudbine, kojem je beg na samrti „sve u pero govorio“( 70):

\footnotetext{
${ }^{49}$ Usp. Glavina, Vesna. 2016. Tvrđava Klis: Priča o uskocima i Petru Kružiću, str. 20. Zagreb: Školska knjiga.
} 
„I on mi tada reče (istaknula D. M. L.): „Piši Matija, piši. Ja, Ilijas-beg Ilijasbegović, sin Enver-bega kadije trebinjskog i unuk slavnog ratnika Ilijas-bega od Fojnice, opraštajući se sa životom što mi ga dragi Bog dade, želim čas prije negoli krenem put neba, kratko poručiti nešto svojim najbližima. (...) Sve će to potvrditi moje kazivanje. kao i ono što prijatelj Matija, sam svojim očima jasno vidje_(istaknula D. M. L.) dijeleći sa mnom moje prokletstvo.“

Mladi Gjivo Zamanjić upoznao je svog vršnjaka Ilijas-bega u Carigradu 1670. godine kada je došao zamijeniti jednog umrlog člana poslanstva Dubrovačke Republike. (7) (...) Mnogo je puta ser Gjivo pred Matijom priznao (istaknula D. M. L.) „,svoj veliki dug Ilijas-begu“" napominjući da mu za to neće dužan ostati.“"(11)

Pripovjedač na fra Matijin rukopis upućuje u fusnoti i to nakon prvih Ilijasovih riječi, da bi se kasnije na fra Matijine zapise o životu Ilijas-bega pozivao tijekom fabularnoga izlaganja, ponekad prepričavajući ih, a ponekad navodeći doslovno Matijine misli: ,piše fra Matija“ (26), „kaže fra Matija u svojim zapisima“ (35) „fra Matija u svojim zapisima zaključuje“ $(58) \ldots$

Da bi rekonstruirao život Ilijas-bega, kapetana trebinjskoga iz 17. stoljeća, pripovjedač se osim na Matijine zapise kao temeljne, poziva u jednome dijelu na zapise Ilijasova poznanika Gjive (v. str. 50) te na zapise fra Nikole, gvardijana samostana u kojem je Matija sakrio prijatelja Ilijas-bega (v. str. 54).

Na samome kraju Ilijas-bega, kapetana trebinjskoga pripovjedač uključuje zapise Sultanije, žene Ilijas-begova sina Hasan-bega: „kako Sultanija piše“ (76).

Sultanijini će zapisi, uz usmeno kazivanje Hasan-begova prijatelja Enesa, predstavljati dva ključna vrela za iznošenje Hasan-begova privatnoga i javnoga života (18. stoljeće) u drugome dijelu petoknjižja - Inšallah, a pripovjedač će na njih upućivati u fusnotama.

Sultaniji zapisi i Enesova kazivanja kontinuirano će se izmjenjivati sve do samog kraja romana Inšallah, kad će pripovjedač u izlaganje uključiti i fragmente Hasan-begovih zapisa nastalih u vrijeme njegova ratnoga zarobljeništva, a koje će njegovi nasljednici prepisivati i učiti napamet (v. str. 309 i 312).

Kao što je u prvom romanu petoknjižja fra Matija bio svjedok i zapisivač Ilijas-begova „prokletstva“, u trećem dijelu petoknjižja imenom Begovina fra Ivan Lovrenović, prijatelj unuka onoga Ilijas-bega iz prvoga dijela petoknjižja (znakovito je da nosi djedovo ime) za sebe kaže da je „svjedok Ilijas-begove golgote“ (417). 
U Zapisima sa Soče i Piave, na koje se pripovjedač poziva unutar osnovnoga teksta ${ }^{50}$, fra Ivan Lovrenović donosi kroniku Ilijas-begove nesreće proizašle iz okvira Prvoga svjetskog rata.

U posljednjem dijelu petoknjižja Ilijasbegovići pod imenom Od Mostara do Den Haaga pripovjedač sve do kraja romana tek spominje zapise nekih likova, primjerice zapise Ilijasa (unuk Ilijas-bega iz Begovine) ili zapise Ilijasova rođaka Ilijas-bega s nadimkom Rus. Pozivanje na iskaz svjedoka prisutno je tek na samom kraju romana kad Rusov sin Enko u haškom pritvoru , „baš kao i njegov prapradjed“, „,govori u pero“ kome drugom nego nekom fra Petru:

„Piši, fra Petre, piši! Uoči prve godine trećeg tisućljeća, ja, Enver-beg Ilijasbegović, sin Ilijas-bega, partizana, zvanog Rus, vojnik, domoljub, rodoljub i pustolov, krivnjom drugih, a ponešto i svojom, provodeći u tamnici Scheveningenu možda i posljednje godine života kao osuđenik za ratne zločine po zapovjednoj odgovornosti, obraćam se čitateljima..." (1002)

\subsubsection{Svjedok kao pripovjedač}

Pripovjedačka pozicija romana Uvod u tvrđavu predstavlja otklon od preostala dva romana dubrovačke trilogije. Uzevši u obzir opseg sudjelovanja u priči, riječ je o homodijegetičnome pripovjedaču, dakle onome koji sudjeluje u priči (v. Rimmon-Kenan 1989: 90 - 92). Tako je stvorena pripovjedna situacija u kojoj neka vanjska instanca ne govori uime likova svjedoka, naime svjedoci i sami postaju pripovjedači, dobivaju ,glas“ te neposredno iznose svoju priču.

Kako je prethodno rečeno, svi svjedoci u Uvodu u tvrđavu imaju status likova (glavnih ili sporednih), a roman je, oslanjajući se na konvenciju pronađenoga rukopisa, u cijelosti građen kao govor svjedoka događaja. Tako je fabula ovog Šehovićeva romana iznesena kombinacijom raznovrsnih pisanih svjedočenja - zapisima po uzoru na biblijska evanđelja (Ropstvo po Luki, Muke po Josipu) te epistolarnim, dnevničkim, kronikalnim i poetskim oblicima, ali i usmenim kazivanjem svjedoka u poglavljima pod nazivom Govorenje svjedoka.

\footnotetext{
${ }^{50}$ Na primjer: „zapisuje fra Ivan u svojim Zapisima sa Soče i Piave“ (384), ,ovu anegdotu navodi fra Ivan u svojim Zapisima...“ (413), ,fra Ivan Lovrenović prisjeća se“ (417), „kako zapisa fra Ivan“ (429)...
} 
„Što se (...) pronađenih rukopisa tiče, premda ih smatramo primjerima pripovijedanja u prvom licu, većina takvih tekstova u povijesti književnosti ima kraći ili duži narativni okvir u kojem njihov nalaznik ili 'urednik' objašnjava čitateljima kako je došao do tih zapisa i zašto ih je odlučio objaviti. (...) Naratološki gledano, to znači da je riječ o tekstovima koji imaju i ekstradijegetičkog-heterodijegetičkog pripovjedača (koji se predstavlja kao 'urednik') i intradijegetičkog-homodijegetičkog pripovjedača (autora ili autoricu pisama ili dnevnika).“ (Grdešić 2015: 104)

Upravo je opisana situacija zaobišla Šehovićev Uvod u tvrđavu: ni predgovorne ni pogovorne bilješke, primjerice, ne upućuju na nekakvoga nalaznika i/ili urednika pronađenih zapisa. Iz ovoga razloga roman funkcionira isključivo kao zbir rukopisa, što povlači pitanje samog postojanja pripovjedača u djelu. Rimmon-Kenan mišljenja je kako i u takvim slučajevima „postoji kazivač u priči (...) 'viši' pripovjedački autoritet odgovoran za 'transkripciju' pisanih zapisa“ (prema Grdešić 2015: 103), slijedom čega Grdešić zaključuje da svaki tekst ima pripovjedača, s tim da se ,pitanje više pripovjedačke instancije može shvatiti i kao čisto tehničko pitanje, osobito s obzirom na činjenicu da u navedenim tekstovima, ako na trenutak u zagrade stavimo postojanje vidljivog ili konstruiranog pripovjednog okvira, dominira autodijegetičko pripovijedanje“ (2015: 106).

Najveći prostor u romanu Uvod u tvrđavu dan je Lukinim pisanim svjedočenjima. U Ropstvu po Luki u sedam dijelova (I. - VII.) iznesena su Lukina višegodišnja iskustva po europskim logorima (Aushwitz, Jadwiga, Papinka, Norilsk i Krasnojarsk) koja je dijelio s prijateljem Pepom.

Epistolarom, koji sadrži Lukina pisma (sestri Madi, bratu Nikši i Pepu) te Lukinim dnevničkim zabilješkama (10. listopada 1960. - 3. 11. 1983.) zahvaćeni su događaji nakon Lukina izlaska iz ,ropstva“.

Logorska su iskustva prezentirana manjim dijelom i Pepovim ,glasom“ u poglavlju Muke po Рери (Josipu), u kojem ovaj zakleti (komunistički) vjernik i idealist, progovara o robovanju na Golome otoku.

Kronotopski gledano, Lukin se i Pepov govor u početnom dijelu romana odvija na dva plana: traumatičnim iskustvima po europskim logorima za vrijeme Drugoga svjetskog rata suprotstavljen je svijet sjećanja na idilu djetinjstva i mladenaštva provedenih najvećim dijelom u Dubrovniku. 
Prva tri dijela Ropstva po Luki (I. - III.) tako su kombinirana s poglavljima koja tematiziraju sjećanje protagonista na neka prošla, sretnija vremena - Josip (Pepo) se sjeća djetinjstva te Lukina prisjećanja na monaha Arkadija.

I ,u romanu Uvod u tvrđavu, kao i u Oslobađanju đavola, prisutna je govornička polifoničnost““ (Matanović 1998: 296), s tim da su raznolikost i broj svjedoka u Uvodu u tvrđavu zamjetno veći nego u Oslobađanju đavola.

Brojnost i raznolikost svjedoka u Uvodu u tvrđavu realizirana je sporednim likovima, koji uz protagoniste Luku i Pepa, svoje pravo na govor dobivaju upravo u poglavljima koja nose signifikantan naslov Govorenje svjedoka.

Lukini zapisi (Ropstvo po Luki) o robovanju po europskim logorima za vrijeme Drugoga svjetskog rata na četiri su mjesta (poslije Ropstva po Luki III., IV., V. i VI.) ispresijecana poglavljima s nazivom Govorenje svjedoka, u kojima glasovi sporednih likova svjedoka, iznošenjem podataka iz vremena prije Lukinih i Pepovih logorskih iskustava, upotpunjuju Lukin govor ostvarujući tako cjelovitost i zaokruženost iznesenih sudbina protagonista. S obzirom da nisu naznačena imena svjedoka i njihova veza s protagonistima, čitatelj istraživački, postupno razotkriva kome pripada glas koji svjedoči o Lukinu i Pepovu životu.

Završni dio Uvoda u tvrđavu formiran je kao Sastavljačeva kratka kronika daljnjih zbivanja, čime se sugerira da je zapravo čitav roman zbir spisa, bilježaka, ništa drugo do žanrovski šarolik pronađeni rukopis. Do izražaja opet dolazi odnos među tekstovima; u ovom slučaju riječ je o odnosu samoga teksta romana prema Pepovoj Tvrđavi kao intertekstu jer roman koji čitatelj drži u rukama predstavlja se kao uvod u čitanje fiktivne Pepove drame Tvrđava - uvod u Tvrđavu.

Podatak da ime i prezime sastavljača rukopisa odgovara onome na koricama knjige izaziva u čitatelju efekt „kratkoga spoja“ (Lodge 1988: 283) budući da se razbija ,jaz između teksta i svijeta, između umjetnosti i života“ (284). Raul Mitrovich - ime je i prezime koje povezuje „,zbilju“ unutar i izvan teksta: riječ je o unuku i „duhovnom sljedbeniku“ (Zima 1989: 255) lika Pepa Mitrovicha, ali i o pseudonimskom odabiru Feđe Šehovića.

„Spretno privodeći radnju finalu, pisac isprepliće likove i izjednačuje ih u istoj točki, identificirajući ih zapravo s apokrifnim autorom, tj. sa samim sobom. Između umjetnosti i zbilje kao da je ukinuta svaka razlika..." (Zima 1989: 255).

Ovakvim se narativnim izborom Šehović očito ,i postmodernistički poigrao pitanjem autorstva te odnosom fikcije i fakcije“ (Nemec 2003: 281). 
Osim u Uvodu u tvrđavu, situacija u kojoj je lik-svjedok ujedno i pripovjedač prisutna je u dijelu sage o Ilijasbegovićima.

U 32. poglavlju Begovine, trećeg dijela Ilijasbegovića, ekstradijegetička-heterodijegetička pozicija pripovjedača naglo zaokreće u homodijegetičnost, da bi se nastavila tijekom čitavog četvrtog dijela Ilijasbegovića naslovljenog Dubrovački intermezzo.

Fusnota na završetku Dubrovačkoga intermezza upućuje na pokušaj pisanja ,pripovijesti o vlastitom životu“" (Biti 2000a: 18), dakle na autobiografski diskurs:

„Završavajući u Zagrebu ovu pripovijest o svojemu dječaštvu, točno tri godine nakon mojeg dolaska u Mostar...“(724)

Mladi Ilijas, unuk Ilijas-bega (protagonista prvoga dijela Begovine) zauzima pripovjedačko mjesto u drugom dijelu Begovine i Dubrovačkome intermezzu.Tako je čitatelju „iz prve ruke“ predstavljen Ilijasov život, preciznim vremenskim koordinatama, od rođenja ${ }^{51}$ do punoljetnosti $^{52}$.

Ilijasova (pri)povijest je, kao i u preostalim Šehovićevim povijesnim romanima, primjer zahvaćanja velikih povijesnih događaja (ovdje Drugi svjetski rat) „odozdo“, pozicijom „maloga čovjeka“, s tim da je ovdje takav položaj dodatno podcrtan uporabom dječje/mladenačke perspektive.

51 „Dakle, rodio sam se u Begovini početkom proljeća 1930،“(454)

52 „Bio je to 15. ožujak 1948., dan prije mog osamnaestog rođendana.“ (721) 


\subsubsection{Svjedok $\neq$ lik}

U kontekstu svjedoka koji nemaju status lika u romanima, Gorak okus duše oslanja se na svjedočenje fra Mavra S..$^{53}$ posredstvom paracitatne rukopisne kronike na koju se upućuje u predgovoru romana.

Po pitanju pripovjedačkoga položaja specifičnost je Gorkoga okusa duše upravo u njegovu predgovoru koji se poigrava granicom između autora i pripovjedača kao čvrsto odijeljenim instancama.

Ekstradijegetički-heterodijegetički pripovjedač postavlja/predstavlja se kao Autor romana koji će uslijediti nakon predgovora. Obraća se čitateljima u prvoj osobi govoreći da će na osnovi pronađene rukopisne građe fra Mavra S. iz 1620. godine

„napisati roman o sudbini fra Vincenca i njegova neputa Vicka, uvjeren da njihova muka ne pripada samo davnom šesnaestom stoljeću“ (GOD: 10), čime se ostvaruje „metaleptički, odnosno metafikcionalni učinak“ jer se „razotkriva postupak pisanja i nastanka pripovjednoga teksta“ (v. Grdešić 2015: 100). Pozivanje na Mavrov rukopis izvan predgovora, dakle u okviru daljnjeg fabularnog tijeka romana, uvijek je ostvareno u odnosu prema Vickovu svjedočenju. Tako, kao i u Oslobađanju đavola $^{54}$, nalazimo primjer suodnosa iskaza svjedoka.

U usporedbi s fra Mavrom S. iz Gorkoga okusa duše, koji svojom kronikom svjedoči na temelju tuđih svjedočenja (svjedoči o onome što je pročitao, ali nije sam proživio, dakle „,iz druge ruke“), svjedoci u Oslobađanju đavola, i kad nisu likovi u romanu, sve su to „vidjeli svojim očima“.

\footnotetext{
${ }^{53}$ Istovjetnost imena i svojstava (fratar, poeta, zamjeranje Dubrovačkoj Republici, kazna) može navesti na povezivanje fra Mavra S. iz Gorkoga okusa duše, ,za kojega neki znanstvenici tvrde da se radi o Mavru Sorkočeviću, učenom fratru i poeti, koji se nešto krupno zamjerio Dubrovačkoj Republici, a ona ga, zbog nekih posebnih razloga, ili obzira ne kazni najtežom kaznom, nego progonstvom u ovaj nekad dalek i pust kraj“" (GOD: 9) s fra Mavrom Sarakom, pjesnikom mrskim Dubrovačkoj Republici iz Oslobađanja đavola.

U ovome slučaju došlo bi do nekih vremenskih nepoklapanja jer je rukopisna Kronika fra Mavra S. (GOD) datirana u 1620. godinu, dakle fra Mavro je te godine kao prognanik iz Dubrovačke Republike već neko vrijeme boravio na prostoru Vitaljine (krajnji jug Konavala), a fra Mavro Saraka kao protagonist Oslobađanja đavola smješten je na prostor Dubrovnika prije, tijekom i nakon velikog potresa 1667. Ipak, ovakva su poklapanja u romanima novopovijesne varijante zanimljiva jer izravno ukazuju na ponovljivost ljudskih sudbina. S druge strane, nameće se upitnost datiranja povijesnih spisa: čitatelj se može pitati potječe li fra Mavrova Kronika zaista iz 1620. ili možda iz nekog kasnijeg vremena, a što bi omogućilo znak istovjetnosti fra Mavra iz GOD i fra Mavra iz OĐ.

${ }^{54}$ Misli se na suodnos Andrinih sjećanja iznesenih u kronici Zapisi o paklu i fra Mavrovih naknadnh intervencija u Andrine zabilješke (komentari na marginama rukopisa, prepravljanja, nadopisivanja).
} 
Takvi svjedoci svoje testimonijalne iskaze o velikom potresu koji je zahvatio Dubrovnik 6. travnja 1667. godine daju u epistolarnoj formi privatnoga karaktera.

Početak romana donosi ulomak pisma (u cijelosti pisan velikim tiskanim slovima, sugerirajući tako imperativni ton) koje Nikša Bona kao preživjeli sudionik potresa šalje svome rođaku u Mlecima. Kako je već spomenuto ${ }^{55}$, sadržaj pisma moralizatorski poučava o nemogućnosti učenja iz povijesti:

„ni iz ove strašne nesreće sigurno nećemo izvući nikakve pouke, kao što nismo ni iz onih prethodnih“(8).

Kao iskaz svjedoka stravičnog potresa u dva završna poglavlja romana (25. i 26.) uvedeni su fragmenti iz pisama ser Francisca Paola de Bobalija (18. travnja 1667.).

Fusnotama se upućuje na podrijetlo tih pronađenih fragmenata pisama te se navodi i njihov prijevod s talijanskoga, kao i suvremena prilagodba staroga dubrovačkog govora.

Ovakvim se narativnim rješenjima pridonijelo dojmu autentičnosti iznesenih epistolarnih svjedočenja o tijeku samoga potresa te njegovim posljedicama.

Za razliku od Gorkog okusa duše i Oslobađanja đavola, u kojima postoje svjedoci koji nisu likovi, posljednji roman dubrovačke trilogije - Uvod u tvrđavu - u cijelosti je izgrađen na govoru svjedoka koji imaju status likova u romanu.

U Ilijasbegovićima je pozivanje pripovjedača na svjedoke koji nemaju status likova u romanu zamjetno jedino u prvome dijelu sage - Ilijas-beg, kapetan trebinjski.

Pripovjedač u fusnoti upućuje na rukopis trebinjskoga kadije Ahmet-age Karamehmedovića (27), ali se i tijekom samog pripovijedanja događaja vezanih za Ilijas-begovu sudbinu poziva na Ahmet-agine zapise: ,zapisuje kadija trebinjski“ (18), „po kadijinim zapisima“ (38), „zapisao je trebinjski kadija Ahmet-efendija Travničanin“ (48)...

Osim upućivanja na imenovane svjedoke i ,provjerljive“ dokumente (kojima se navodi naziv, sadržaj, vrijeme nastanka i sl.), u Gorkom okusu duše, Oslobađanju đavola, Prokletoj ergeli i sagi Ilijsbegovići mogu se zamijetiti općenita pozivanja na usmene ili pisane iskaze koji se ne mogu ovjeriti, čije je podrijetlo nepoznato. I na takvim mjestima vidljiva je sukobljenost povijesnih tumačenja. ${ }^{56}$

\footnotetext{
${ }^{55}$ Vidi potpoglavlje „Romani dubrovačke trilogije Feđe Šehovića u kontekstu žanra hrvatskoga povijesnog romana".

${ }^{56} \mathrm{O}$ tome više u narednim potpoglavljima rada vezanima za dokumente.
} 


\subsubsection{Pripovjedač: završne napomene}

O ekstradijegetičkim-heterodijegetičkim pripovjedačima često se govori kao o onima koji imaju svojstvo omniscijencije/sveprisutnosti, naglašava Rimmon-Kenan (1989: 91) iznoseći svojstva takvih pripovjedača: „,bliskost, u načelu, s karakterovim najskrovitijim mislima i osjećajima; znanje o prošlosti, sadašnjosti i budućnosti; nazočnost na mjestima gdje se pretpostavlja da su karakteri bez pratnje“" (isto).

Upravo takvi pripovjedači jedna su od specifičnosti najistaknutijih predstavnika suvremenoga hrvatskoga povijesnog romana - Ivana Aralice, Feđe Šehovića i Nedjeljka Fabrija. ${ }^{57}$ Ipak, nije riječ o nevidljivom, nenametljivom pripovjedaču povučenome u pozadinu, pripovjedaču flaubertovskoga tipa koji, uvjetno rečeno, ne vrednuje i ne zauzima stav. Na vrhu ljestvice uočljivosti/perceptibilnosti pripovjedača u tekstu ${ }^{58}$ Rimmon-Kenan (1989: 94 - 96) postavlja komentare, ističući kako se oni mogu odnositi na razinu same priče (interpretacije, prosudbe i generalizacije), ali i na naraciju (osvrti na vlastito pripovijedanje). Upravo frekventna uporaba komentara, a posebno generalizacija, snažno doprinosi ostvarenju moralističnoga tona spomenutih književnika, ali i općenito pisaca suvremenih hrvatskih povijesnih romana.

Za razliku od Aralice i Šehovića ${ }^{59}$, koji komentare uglavnom zadržavaju na razini priče, pri čemu se generalizacije odnosno univerzalni iskazi o čovjeku i pojavnostima koje ga okružuju javljaju kao stalno mjesto u njihovu romanesknome izričaju, Fabrio koristi i komentare

\footnotetext{
57 „Jedan od danas, uz Ivana Aralicu i Feđu Šehovića, najznačajnijih autora novopovijesnoga romana jest Nedjeljko Fabrio.“ (Matanović 1998: 276)

${ }^{58}$ Rimmon-Kenan navodi znakove perceptibilnosti pripovjedača u tekstu po kriteriju sve većeg stupnja perceptibilnosti: 1. opis ambijenta radnje; 2. identifikacija karaktera; 3. vremenski sažetak; 4. definicija karaktera; 5. izvještaji o tome što karakteri nisu mislili ili rekli; 6. komentari (1989: 92 - 96).

${ }^{59}$ Primjeri generaliziranja, odnosno univerzalnih iskaza u Šehovićevim romanima:

„I neznatnim odstupanjem podanik postaje čovjek sa suvišnom osobinom koji se ne uklapa u šemu vladajućeg pogleda na svijet..." (GOD: 136)

„Ali, ma koliko se ljudi slobodna duha trsili u raskrinkavanju fanatika, masa je uvijek sklona cijeniti njihovo dogmatsko čistunstvo..." (OĐ: 18)

„,najbolnija su razočaranja ona u vlastite ideale“ (OĐ: 39)

„Pravu tvrđavu za sebe čovjek gradi u sebi i zato je neosvojiva.“(UUT: 107)

„A ljudi najčešće dižu ruku na sebe kad im istina postane nepodnošljiva.“ (UUT: 163)

„Ništa u životu ne može tako brzo uništiti čovjeka kao vlastita zabluda o svijetu u kojemu živi.“ (PE: 147)

„Mudrost suživota i sastoji se u neprestanim pokušajima da se onaj drugi shvati i razumije.“ (Ilijasbegovići I: 32)

„Čaršija je takva, bez kruha i soli može preživljavati, ali bez zloće i zavisti ne može.“ (Ilijasbegovići II: 177)

„Promašaji u životu su prirodni, ali je neprirodno ako nam se samo oni događaju.“ (Ilijasbegovići IV: 707)
} 
naracije, odnosno komentira sam čin pripovijedanja, pri čemu se njegov pripovjedač/povjerenik za priču ${ }^{60}$ nerijetko „obraća“ čitateljima, ali i samim likovima ${ }^{61}$.

Što se tiče pouzdanosti, „nepouzdan može biti i ekstradijegetički-heterodijegetički pripovjedač koji je sklon komentiranju radnje i likova te ukazivanju na vlastito postojanje, kao i homodijegetični pripovjedač koji sudjeluje u radnji“ (Grdešić 2015: 118 prema Rimmon-Kenan 2002: 104).

Kao što je već spomenuto, Araličini, Šehovićevi i Fabrijevi pripovjedači ne sustežu se od komentara, što bi ih na stanovit način, prema upravo spomenutome kriteriju, etiketiralo kao nepouzdane. Ipak, pri usporedbi sa stranim piscima suvremenih povijesnih romana, književnoznanstvena literatura konstatira da ,upravo tu instanciju 'nepouzdana pripovjedača' nedovoljno koristi hrvatski novopovijesni roman, čega su konzekvencije 'potpuno' znanje i vladanje situacijom, a ne nesigurnost i sumnja, ironija i književno poigravanje“ (Milanja 1994: 1085).

Ovom prilikom valja ipak istaknuti da, iako im u ophođenju s povijesti parodija i ironija nisu previše bliske, hrvatski pisci suvremenih povijesnih romana prema svjedocima i povijesnim izvorima zauzimaju značajno drugačiji stav negoli su to činili pisci povijesnoga romana šenoinskoga tipa. Naime, može se uočiti da je povjerenje zamijenila ,sumnja u povijest kao glavna karakteristika novopovijesne varijante“" (v. Matanović 1998: 294 - 318).

Tako, primjerice, Fabrijev pripovjedač direktno izražava sumnju u vjerodostojnost povijesnih izvora, dok pripovjedač Ivana Supeka u Buni Janusa Pannoniusa to čini više indirektno, „,između redaka“(v. Matanović 2003: 140 - 141).

Iako će o tome više biti riječ u narednim poglavljima, valja odmah spomenuti da je upravo sumnja važan segment karakterizacije Šehovićevih likova-svjedoka.

Iako Šehovićevi pripovjedači uglavnom ne izriču direktno ( primjerice u svojim komentarima) sumnju u vjerodostojnost povijesnih zapisa, autoritet povijesnih izvora doveden je u pitanje samim izborom vrste dokumenata na koje se pripovjedači pozivaju, kao i naglašavanjem intertekstualnoga konteksta u koji je svaki od zapisa postavljen.

\footnotetext{
${ }^{60}$ N. Fabrio svoga pripovjedača imenuje povjerenikom za priču, npr. ,(...) ja sam tu da ti kao takav, ajmoreć povjerenik za priču, pripovijedam o neuhvatljivim bojama duše (...) ( Fabrio 2002: 34); ,„...) jer sam kao samovlasni povjerenik za priču dužan to učiniti (...) (isto: 37 ).

${ }^{61}$ Primjeri Fabrijevih komentara na razini naracije: „Mogao sam priču o tebi, Lucijane, i o tvojoj nježnoj, gotovo dječačkoj ljubavi započeti odmah, ali sam radije izabrao duži, mnogo duži put, smatrajući da sam kao pričalo dužan ispripovijedati sve što znam o biologiji obitelji u koju ćeš se, Lucijane, igrom slučaja uplesti. (...) Ali nisam ja zvao povijest, nisam ja izmislio povijest! Pa ona se sama kao suh čičak, nametljivo i do krvi ranjivo lijepila o moje pripovijedanje! (Fabrio 2005: 222) „Moj čitatelju, ti koji si imao volje, strpljenja, ljubavi i vremena da stigneš do ovih redaka...“(Fabrio 2002: 317) „Adieu, Andrej. To ja govorim tebi, a ne tvoj otac. U ovoj knjizi o očevima i o sinovima, o nevjestama i o njihovoj djeci, ti si moje dijete, Andrej, Andrej, ti si ja...“(Fabrio 2002: 351)
} 
Iz prethodnih je potpoglavlja vidljivo da Šehović, poput Fabrija i Aralice, ponajviše koristi situaciju u kojoj se ekstradijegetički-heterodijegetički sveznajući pripovjedač, kao neka vanjska instanca koja sve promatra i nadgleda, poziva na pisana svjedočenja i usmene iskaze svjedoka.

Dok je „Fabrijev narator naš suvremenik koji odista govori o povijesti, simptomatično je za pripovjedne postupke Ivana Aralice da su njegovi naratori fiktivni likovi iz prošlosti (pretežno 16. i 17. stoljeće) koji očituju neposredan odnos suvremenika i znalaca prema epohi o kojoj izvještavaju“ (Matanović 1998: 290).

Aralica sveznajuću pripovjedačku poziciju napušta u Graditelju svratišta, mada se ovdje, „bez obzira na pripovijedanje u prvome licu, ne može govoriti o nekoj bitnoj strukturnokompozicijskoj i retoričkoj promjeni: Araličin kazivač Jakov Grabovac uglavnom preuzima ingerencije sveznajućeg naratora“ (Nemec 2003: 276).

Ova bi se Nemecova konstatacija velikim dijelom mogla primijeniti i na pripovjedačku situaciju jednoga dijela Šehovićeve sage o Ilijasbegovićima, gdje u posljednjim poglavljima trećega dijela sage (Begovina) te u četvrtome dijelu (Dubrovački intermezzo) pripovjedačko sjedište zauzima lik-svjedok Ilijas.

Šehović je inovativnu pripovjednu perspektivu ostvario u Uvodu u tvrđavu, gdje je homodijegetično i autodijegetično kazivanje čitatelju izloženo bez unaprijed ili naknadno danog narativnoga okvira (npr. u predgovornim ili pogovornim bilješkama urednika pronađenih rukopisa koji bi zauzeo status klasičnog ekstradijegetičnoga-heterodijegetičnoga pripovjedača), čime je ostvarena iluzija rukopisa koji „sami govore“. 


\subsection{Fokalizacijska pozicija svjedoka ${ }^{62}$}

Kojim je strategijama ostvareno viđenje povijesnih zbivanja u Šehovićevim povijesnim romanima? Koji svjedoci predstavljaju očište, točku gledišta povijesnih (ne)prilika? Tko gleda što/koga i na koji način?

Odgovori na ova pitanja razmotrit će se u okviru naratološkog modela književne teoretičarke Mieke Bal, koja za viđenje, odnosno perspektivu događaja u pripovjednim tekstovima, preuzima Genetteov termin fokalizacija ${ }^{63}$.

Bal fokalizaciju promatra kao „odnos između vizije i onoga što se vidi, uočenog“ (Bal 2000: 119), naglašavajući da, s obzirom da se radi o odnosu, ,,moraju se uzeti u obzir i subjekt i objekt fokalizacije“"(123).

Ova teoretičarka razlikuje internu i eksternu fokalizaciju. O internoj se fokalizaciji govori u slučaju kad se fokalizacija nalazi pri liku koji sudjeluje u radnji, a o eksternoj ako je fokalizator izvan fabule (v. $124-125$ ).

Ponekad, kad se čini da „eksterni fokalizator pozajmljuje fokalizaciju liku fokalizatoru, zapravo se daje jedno viđenje lika fokalizatora unutar sveobuhvatna viđenja eksternoga fokalizatora. On zapravo uvijek drži fokalizaciju, u kojoj fokalizacija lika fokalizatora može biti umetnuta kao objekt.“ (Bal 2000: 132)

Upravo je opisana fokalizacijska situacija primjenjiva na romane Gorak okus duše, Oslobađanje đavola, Prokletu ergelu i najveći dio romanesknoga ciklusa Ilijasbegovići.

U prvome je dijelu Gorkoga okusa duše posredstvom don Vickovih / fra Mavrovih zapisa u „sveobuhvatno viđenje eksternoga fokalizatora“ (v. prethodni citat) ugrađeno Vincencovo viđenje događaja. Mjestimičnim unošenjem Vincencova pogleda eksterni fokalizator iznosi događaje prije Vincencova susreta s nećakom Vickom i njihova zajedničkoga robovanja u Italiji.

Iako se ekstradijegetični-heterodijegetični pripovjedač tijekom cijeloga romana poziva na Vickove zapise, Vicko je kao fokalizator prisutniji u drugom dijelu romana, u kojem se zbog smrti povlači lik Vincenco.

\footnotetext{
${ }^{62}$ Ovo će potpoglavlje rada biti znatno kraće u odnosu na prethodno jer svi su svjedoci i zapisi putem kojih svjedoče već predstavljeni. Isto tako, svjedoci koji su pripovjedači (imaju glas) istovremeno su i fokalizatori zbivanja o kojima pripovijedaju.

${ }^{63}$ Vidi: Genette, Gérard. 1992. Tipovi fokalizacije i njihova postojanost. U: Suvremena teorija pripovijedanja, uredio Vladimir Biti, 96 - 115, prevela Dubravka Celebrini. Zagreb: Globus.

„Dok Genette fokalizaciju definira kao sužavanje polja, odnosno kao pitanje znanja i informacija, drugi teoretičari, a u prvom redu njegova najveća kritičarka Mieke Bal, shvaćaju fokalizaciju kao pitanje gledanja.“ (Grdešić 2015: 137)
} 
Izravna prezentacija pjesničkoga viđenja traumatskih iskustava dana je uobličavanjem završnog poglavlja romana (IX.) kao Vickove pjesničke zbirke.

Zbivanja su i u Oslobađanju đavola: Kronika uglavnom predočena eksternim fokalizatorom, dakle točkom gledišta smještenom izvan fabule, čime su zadovoljeni zahtjevi kronike za objektivnim, neutralnim tonom.

U cilju postizanja efekta autentičnosti i uvjerljivosti govora o velikom dubrovačkom potresu te mjesecima koji su mu prethodili, eksterni fokalizator na određenim mjestima ,prepušta“ fokalizaciju svjedocima potresa.

Tijekom samoga pripovijedanja česta su uključivanja fokalizacije suca Andre: pozivanjem na sadržaj njegove kronike Zapisi o paklu donosi se Andrino viđenje zbivanja u Dubrovniku šest mjeseci prije potresa, a time i mogućnost objašnjenja uzroka ove velike katastrofe.

Tom se prilikom Andrina fokalizacija isprepliće s fokalizacijom ozloglašenog dubrovačkog pjesnika fra Mavre, koji svojim dopunama, prepravljanjima i komentarima Andrina rukopisa u Andrinu kroniku unosi i svoj „glas“ i ,pogled“.

Izravni fokalizacijski umeci svjedoka samoga potresa ostvaruju se Andrinim kronikalnim fragmentima te epistolarnim fragmentima svjedoka. Na ovaj način u vanjski pogled na zbivanja uključena je i percepcija iz unutarnjega kuta.

Eksterni fokalizator u Prokletoj ergeli najviše je fokalizacijskoga prostora osigurao liku fra Andrije, nositelju pregovora o uvjetima okončanja kršćansko-muslimanskoga sukoba na Klisu 1648. godine.

Kao subjekt fokalizacije fra Andrija je zastupljen preko svojih zapisa $O$ životu $i$ djelu fra uzora Ilije (1648.). U zapisima mladoga fra Andrijina nastavljača fra Marka Život i djelo pravednika fra Andrije A. i njegova uzora fra Ilije K. (1689.) fra Andrija je postavljen u poziciju objekta fokalizacije. Ipak, na mnogim mjestima fra Marko kao fokalizator citira fra Andrijine riječi, čime je omogućeno kontinuirano izmjenjivanje fra Andrijina fokalizacijskoga položaja - i kao subjekta i objekta fokalizacije.

Radi što uvjerljivijeg dočaravanja mučenja turskih vojnika i civila u Prokletoj ergeli eksterni fokalizator osigurao je umetke s internom fokalizacijom, navodeći kazivanja dočasnika Livnjaka i zapovjednika Ali-age.

Objekt fokalizacije prvoga dijela sage o Ilijasbegovićima pod nazivom Ilijas-beg, kapetan trebinjski naznačen je već u samom naslovu romana. Sudbina ovoga trebinjskog bega 
iz 17. stoljeća iznesena je „očima“ Ilijasova prijatelja fra Matije Kopčića, koji iz položaja svjedoka u svojim zapisima iznosi Ilijas-begov život, i to od trenutka kad je Ilijas-beg otputovao u Carigrad u funkciji stranoga veleposlanika do trenutka njegovih predsmrtnih riječi koje i započinju molbom: „Piši, Matija, piši.“ (7)

Fokalizacijsko se žarište u drugome dijelu (Inšallah) premješta na Ilijas-begova sina Hasan-bega. Hasan-begov život (18. st.) predočen je uglavnom posredstvom dvoje likova fokalizatora - Hasan-begova prijatelja Enesa i žene Sultanije - pri čemu Enesovo usmeno kazivanje i Sultanijini zapisi obuhvaćaju različite planove fabule.

Uzevši u obzir muški i ženski društveni prostor, Sultanijini zapisi vezani su ponajviše za privatnu sferu (razvoj ljubavnog odnosa s Hasan-begom, obiteljski odnosi, kućanstvo...), a Enesova kazivanja tiču se događaja u javnoj sferi, „izvan kuće“ (putovanja po kršćanskim zemljama, ljubavne afere, ratovanje protiv Eugena Savojskoga, zarobljeništvo u kući gospara Antuna...).

U jednome dijelu, pred kraj romana, uključeno je i očište samoga Hasan-bega. Riječ je o Hasan-begovim zapisima nastalima u zarobljeništvu, a tiču se refleksija o gorčini gubitništva, vjerskoj (ne)isključivosti te bosanskome kismetu.

U prvome dijelu Begovine Hasan-begov nasljednik Ilijas-beg funckionira kao objekt fokalizacije. Dok je Ilijas-begov privatni život zahvaćen uglavnom eksternom fokalizacijom, njegova sudbina na bojišnicama tijekom Prvoga svjetskog rata prezentirana je putem interne fokalizacije: riječ je o pozivanju na ratne zapise Ilijasova prijatelja fra Ivana Lovrenovića, koji za sebe kaže kako je „svjedok Ilijas-begove golgote“ (417).

U drugome dijelu trećeg romana (Begovina) te četvrtom romanu (Dubrovački intermezzo) ciklusa o Ilijasbegovićima prisutno je stapanje instance naratora i fokalizatora $\mathrm{u}$ liku maloga/mladoga Ilijasa, unuka Ilijas-bega. Upravo „naivnost“ pogleda na nekim mjestima ostvaruje efekt očuđenja. Vidi se to, primjerice, u slučaju kad mali Ilijas izjavljuje kako ne zna što su to „rasni zakoni““ (I: 580) ili kad se raspituje o značenju „radnih logora“ (I: 590).

U Begovini mali Ilijas donosi svoje viđenje obiteljskih odnosa tijekom života u na „,begovini“ u Trebinju, a u Dubrovačkome intermezzu zahvaća život nakon preseljenja iz Trebinja u Dubrovnik, što se poklapa s vremenom oko Drugoga svjetskog rata.

Pozicija eksternoga fokalizatora zadržana je u posljednjem/petom dijelu sage o Ilijasbegovićima - Od Mostara do Den Haaga - gdje se prati Ilijasov život tijekom njegovih zreli(ji)h godina. 
Tek pred sam kraj romana (što je i kraj sage), kao interni fokalizator postavlja se Ilijasov (deset godina mlađi) rođak Enko koji sjedi u haškom zatvoru pod optužbom da je tijekom rata u Bosni devedesetih godina 20. stoljeća počinio zločine nad civilima. Enkov je fokalizacijski položaj u tom smislu predočen fragmentima iz njegovih rukopisa nastalima u zatvorskoj ćeliji, izdiktiranima fra Petru, a koje će Ilijasov prijatelj Marko naknadno pročitati i pretipkati.

U Uvodu u tvrđavu, u odnosu na sve ostale Šehovićeve romane, upotrijebljena je isključivo interna fokalizacija, zbog čega se konstantno ostvaruje efekt pogleda iznutra. Svi su likovi svjedoci te iznose svoju priču, svojim riječima, onako kako su je oni vidjeli.

Luko je najčešći fokalizator u ovome romanu. U svojim zapisima Ropstvo po Luki u sedam dijelova iscrpno je iznio viđenje svojih, ali i Pepovih logorskih iskustava.

Pepo se, u kontekstu traumatskih logorskih doživljaja, kao fokalizator javlja u poglavlju Muke ро Рери (Josipu), gdje iznosi svoje samotničko robovanje na Golom otoku, bez Pepa.

Pepove fokalizacijske osobitosti kao pjesnika dolaze do izražaja u njegovim paracitatnim pjesničkim tekstovima: Josipova(Pepova) poslanica prijatelju L. B. i Poslanica prijatelju piscu (iz poslanice Nevjernik) odražavaju umjetničko viđenje zakonitosti poetičke proizvodnje.

Dok su traumatska logorska iskustva uglavnom prezentirana Lukinim viđenjem, sjećanje na idilu djetinjstva u Dubrovniku zastupljeno je u jednakoj mjeri Lukom i Pepom kao fokalizatorima (poglavlje Josip (Pepo) se sjeća djetinjstva i poglavlje Lukina prisjećanja na monaha Arkadija).

Osim što su fokalizatori, dakle subjekti fokalizacije, u svojim se zapisima Luko i Pepo jedan prema drugome postavljaju i kao objekti fokalizacije, fokalizirano, čime se narativno izgrađuju njihovi međusobni odnosi.

Kao objekti fokalizacije Luko i Pepo pojavljuju se u svjedočenjima čitavog niza sporednih likova u romanu. Kako je već ranije spomenuto, ovi likovi iznose svoje viđenje događaja prije Pepovih i Lukinih logorskih iskustava (nestašluke iz djetinjstva, mladenačke interese, ljubavna iskustva, studentske dogodovštine, književno djelovanje, ideološke angažmane...). U Lukinim dnevničkim i epistolarnim bilješkama očituje se Lukino viđenje događaja po izlasku iz ropstva. 
U završnome dijelu romana kao fokalizator nastupa sastavljač svih bilježaka koje svojom objedinjenošću zapravo i čine roman što ga čitatelj drži u ruci - Raul Mitrovich, Pepov unuk, folkalizator je daljnjih zbivanja (nakon Pepove smrti i Lukine Parkinsonove bolesti).

Bio fokalizator eksterni ili interni, u navedenim romanima Feđe Šehovića uvijek je riječ o interpretirajućoj fokalizaciji/interpretirajućem fokalizatoru budući da fokalizator ne uočava samo objekte fokalizacije nego ih i interpretira (v. Bal 2000: 129).

Osim toga, na kraju valja istaknuti i kako se u Šehovićevim povijesnim romanima zbivanja ne iznose rašomonski, dakle nije prisutno viđenje jednog te istog događaja iz perspektive nekolicine likova, odnosno nema višestruke zastupljenosti bilo koje epizode. Naprotiv, u razvoju priče izmjenjuju se fokalizacijske pozicije po principu ulančavanja iskaza svjedoka, čime se cjelovitost priče ostvaruje efektom slagalice. Priča se nadovezuje na priču; ,,priča priču rađa“" (Aralica). 


\subsection{Svojstva likova svjedoka i njihova naratološka izgradnja}

\subsubsection{Uvodne napomene}

Već je iz naslova poglavlja vidljivo kako će pristup likovima u ovome radu uključivati pomirenje dviju teorija: stajalište „realista“, koji lik promatraju kao osobu (zbog čega se likove na neki način može „,izdvojiti“ iz teksta i promatrati neovisno od događaja - mogu se na likove primijeniti određene teorije i čitanja) te stajalište „purista“, koji likove promatraju isključivo kao dio strukture, što znači da ih se ne može izlučiti iz svoje tekstualnosti (Rimmon-Kenan 2002 prema Grdešić 2015: 64).

Analiza će karaktera ${ }^{64}$ tako, riječima Milivoja Solara, ići u dva smjera: pokušat će se obuhvatiti tip čovjeka koji se u književnom djelu opisuje (tematska analiza), ali će se nastojati i analizirati sredstva kojima su određeni karakteri prikazani u djelu - tada je riječ o karakterizaciji (v. Solar 1976: 45 - 46)

Za američkoga naratologa Seymoura Chatmana u raspravama o (književnim) karakterima nezaobilazan je pojam svojstva, zbog čega bi se karaktere trebalo promatrati upravo kao „paradigmu svojstava“, pri čemu se svojstva odnose na „razmjerno postojane ili trajne osobne kakvoće, znajući da se one mogu ili razviti, tj. pojaviti se ranije ili kasnije tijekom priče, ili pak mogu nastajati i biti zamijenjena drugima“" (1983: 125).

Upravo na kombinaciji/skupu svojstava Gajo Peleš temelji svoje određenje narativne figure kao „svake izdvojene i determinirane značenjske jedinice pripovjednoga svijeta“ (1999: 223).

Ovaj književni teoretičar uvodi pojam narativne figure u teoriju likova kako bi popunio prazan prostor koji nastaje između analize likova kao jedinica osobnosti (s jedne strane) i analize nosivih tema kao jedinica opstojanja (s druge strane). Smatra da su pri takvim analizama preskočene neke pojedinačnosti priče, kao npr. skupine likova (221). Stoga se za Peleša pojedinačnosti pripovjednoga teksta uspostavljaju kao tri vrste narativnih figura: narativna figura osobnosti (psihemska narativna figura), narativna figura skupnosti (sociemska narativna figura) i narativna figura opstojanja (ontemska narativna figura). Njihove značenjske sastavnice ili svojstva imenuje kao psiheme, socieme i onteme (228).

\footnotetext{
${ }^{64}$ Likovi se određuju kao karakteri kad je naglasak na njihovim psihičkim osobinama (v. Solar 1976: 45).
} 
Narativne se figure nalaze u hijerarhijskome odnosu, u smislu da se psihemska narativna figura može uklopiti u jednu ili više sociemskih narativnih figura, a sociemske narativne figure mogu se uklopiti u jednu ili više ontemskih narativnih figura (222).

Uz navedene teorijske smjernice pri klasifikaciji likova svjedoka u Šehovićevoj trilogiji od koristi će biti mimetski modusi fikcionalne književnosti kanadskoga teoretičara Northropa Fryea. Fryevi modusi „označavaju kakvoću fikcionalnoga svijeta koja nastaje omjeravanjem junaka bilo ,a) o okolinu u tom svijetu ili b) o obične ljude izvan njega (čitatelje odnosno gledatelje)“ (Biti 2000a: 323).

Tako se fikcionalna djela prema junakovoj moći djelovanja mogu razmatrati u pet modusa: mitski modus (junak nadmoćan po vrsti i drugim ljudima i ljudskoj okolini), romanca (junak nadmoćan u stupnju drugim ljudima i svojoj okolini), visokomimetski modus (junak stupnjem nadmoćan drugim ljudima, ali ne svojoj prirodnoj okolini), niskomimetski modus (junak nije nadmoćan ni drugim ljudima ni svojoj okolini) i ironijski modus (junak svojom moći ili inteligencijom slabiji od nas) (Frye 2000: 45 - 46).

U završnom će dijelu karakterizacija likova biti promotrena i na podlozi koncepta parezije, i to onako kako je vidi francuski filozof Michel Foucault.

Analizom će se obuhvatiti svojstva i naratološka izgradnja onih likova svjedoka koji imaju funkciju protagonista, tj. glavnih nositelja radnje u povijesnim romanima Feđe Šehovića.

Može se zamijetiti kako je Šehović u svakome od romana dubrovačke trilogije književnim sredstvima u prvi plan postavio dvojicu svjedoka - riječ je o antonimskim parovima likova čija individualna sudbina i međusobna interakcija oblikuje idejni sloj romana.

U Gorkome okusu duše tu ulogu preuzimaju likovi dvojice svećenika - fra Vincenca i njegova nećaka don Vicka. Prvi dio romana osvjetljava Vincencov lik, a drugi dio romana Vickov lik. Roman je izgrađen na konvenciji pronađenoga rukopisa - na Vickovu pisanu svjedočenju, koje se pak naslanja na Vincencovo predsmrtno usmeno kazivanje.

Oslobađanje đavola uključuje kronikalni rukopis Zapisi o paklu, u kojem dubrovački sudac Andrija (Andro) Menčetić donosi sliku snažnog potresa koji je zahvatio Dubrovnik 1667. godine. U svojim Sjećanjima ovaj lik donosi osvrte na svog književnog parnjaka fratra, filozofa i pjesnika Mavra Saraku, autora poeme Oslobađanje đavola, a u kojoj 
pjesničkim sredstvima opisuje pretkazani potres u gradu. I dok sudac Andro pravi bilješke o Mavru, kasnije taj isti Mavro dopunjuje i „prepravlja“ Andrine bilješke.

Kao što je već spomenuto, roman Uvod u tvrđavu u cijelosti je oblikovan kao govorenje svjedoka, među kojima prevladava svjedočenje Luke Božidarevića i Josipa (Pepa) Mitrovicha. Riječ je o dvojici najboljih prijatelja, razdvojenih po pitanju ideoloških uvjerenja (vjera u komunizam), a udruženih zajedničkim patnjama, kao i pitanjima književnoga djelovanja.

Središnje mjesto u Prokletoj ergeli zauzima lik fra Andrije, koji je ostvaren kako relacijama prema svojemu prethodniku i uzoru fra Iliji, tako i prema svome nastavljaču fra Marku. Kao što je fra Andrija zapisničar fra Ilijina života, tako će i mladi fra Marko postati zapisničar fra Andrijina životnoga puta. Osim toga, važan je odnos koji fra Andrija ostvaruje sa suvremenikom Ali-agom, dijeleći traumatično iskustvo zarobljeništva.

U kontekstu obimnoga romanesknog ciklusa Ilijasbegovići:Cronica travuniana analiza će se usmjeriti na lik Ilijasa, protagonista najvećeg dijela ove sage. Ilijasova se karakterizacija zrcali u sudbinama njegovih predaka (protagonisti prvih dijelova sage o Ilijabegovićima - prapradjed iz 17. st. Ilijas-beg, pradjed Hasan-beg, djed Ilijas-beg, otac Enver-beg), ali i nastavljačima loze Ilijasbegovića (deset godina mlađi rođak Enko).

U analizi svjedoka-protagonista do izražaja dolazi figura patnje (likovi patnici), odnos prema književnosti te odnos prema ideološkim strukturama. ${ }^{65}$

\footnotetext{
${ }^{65}$ Značajan je i odnos likova-svjedoka prema drugome/strancu, što će biti zahvaćeno u nastavku rada - u sklopu prezentacije svjedočenja u službi identitetnih predodžbi zajednice.
} 


\subsubsection{Patnja: provodna figura Šehovićevih povijesnih romana}

U svome radu Složenost lik-efekta Vincent Jouve povezuje intimnost lika i temu patnje:

„Izgleda da nam se pojedinac može sasvim predati samo kroz svoju bol. (...) Lik koji pati, kao povlaštena podrška osjećajnom ulaganju, zauzima među romanesknim likovima posebno mjesto.“” (2000: 529)

Pri tome se Jouve osvrće na Fragmente ljubavnoga diskursa Rolanda Barthesa, u kojima ovaj francuski teoretičar na jednome mjestu konstatira kako je od kršćanstva za nas subjekt onaj koji pati; tamo gdje postoji rana, postoji subjekt (isto: 529).

Svi su Šehovićevi protagonisti-svjedoci upravo reprezentativan primjer patnika.

Distinkcija komičke tendencije u fikcionalnoj književnosti (uključivanje junaka u društvo) i tragičke tendencije (junak izdvojen iz društva) (Frye 2000: 68) ukazuje na poimanje Šehovićevih likova svjedoka kao tragičnih.

Šehovićevi povijesni romani vrve scenama ugroženosti pojedinca od strane društvenih sila (Gorak okus duše, Uvod u tvrđavu, Prokleta ergela, Ilijasbegovići), ali i od onih prirodnih kojima se traže društveni uzroci (potres u Oslobađanju đavola).

Krugovi patnje samo se nižu jedan za drugim u svakom od romana, s istim i/ili novim akterima.

„Zatvaram li svoj krug robovanja, ili se vraćam na početak novoga?“(UUT:166), retoričko je pitanje koje bi mogao izgovoriti ne samo Luko iz Uvoda u tvrđavu, već bilo koji od navedenih protagonista Šehovićevih povijesnih romana.

Vincenco (GOD) ${ }^{66}$ utamničen je i mučen pod optužbom da pomaže mletačkim uskocima u njihovim napadima na teritorij Turske, a nakon izlaska iz tamnice skupa s nećakom Vickom (GOD) dospijeva u mletačko ropstvo.

Vicko zbog svoga pjesničkog djelovanja biva pritvoren te završava pred Komisijom za ispitivanje vjerskih bludnji.

Fra Mavro (OĐ) nosi u Dubrovniku etiketu otpadnika, a pritvoren je zbog poeme kojom navodno vrijeđa vlast Dubrovačke Republike. Njegov prijatelj Andro (OĐ), sudac i politički neistomišljenik, susreće se s patnjom prilikom gubitka vlastitog sina u potresu koji je zahvatio Dubrovnik.

\footnotetext{
${ }^{66}$ Radi lakšeg snalaženja i ekonomičnosti u zagradama će uz lik kraticom biti naveden naslov romana iz kojeg lik potječe: Gorak okus duše (GOD), Oslobađanje đavola (OĐ), Uvod u tvrđavu (UUT), Prokleta ergela (PE), Ilijasbegovići (I).
} 
Iako suprotnih političkih uvjerenja, Luko i Pepo (UUT) iskusit će kao politički zatvorenici šesnaestogodišnji „boravak“ po logorima i zatvorima (Auschwitz, Jadwiga, Papinka, Goli otok..).

Fra Andrija (PE) završava nevin u bosanskome zatvoru zbog optužbe za ubojstvo nekoliko stotina turskih branitelja prilikom druge opsade Klisa (1648. godine), nastavljajući tako sudbinu svoga prethodnika fra Ilije, koji je pedesetak godina ranije, prilikom prve opsade Klisa (1596. godine), odležao u splitskom zatvoru pod sumnjom da je heretik i turski špijun.

Ilijas (I), izdanak stare trebinjske loze Ilijasbegovića, kao general-bojnik u HVO-u tijekom 90-ih godina smatran je odgovornim za masakr pripadnika HVO-a nad Bošnjacima u jednom od sela srednje Bosne (u to vrijeme Ilijas je bio u kućnome pritvoru), čime slijedi kismet svojih predaka Ilijasbegovića: doživljen je kao odmetnik, izdajnik ,svojih““.

Upravo je spomenuto smještanje likova svjedoka u represivnu okolinu (zatvori, logori, pritvori...) značajan element njihove karakterizacije.

U oblikovanju likova svjedoka Šehović često koristi martirološki leksik ${ }^{67}$. U Gorkome okusu duše Vincenco i njegov nećak Vicko predočeni su prizmom kršćanskog mučeništva, u kojem se sjedinjuju svojstvo svetosti i muke, primjerice:

„odlučih se napisati roman o sudbini fra Vincenca i njegova neputa Vicka, uvjeren da njihova muka ne pripada samo davnom šesnaestom stoljeću“ (GOD: 10, istaknula D. M. L.)

„A fra Vincenco je bio po svemu osoben čovjek, što najbolje pokazuje njegov životni put koji kao da je prepisan iz biografije nekog sveca mučenika“ (GOD: 16, istaknula D. M. L.)

„Tek što je Vicko počeo pričati svoju i ujakovu golgotu“ (GOD: 110, istaknula D. M. L.)

Na status kršćanskih mučenika ukazuju i imena navedenih likova. Ime Vincencije etimologijom priziva pobjedu, pobjednika. ${ }^{68}$ Pobjeda pak ima religioznu simboliku koja se

\footnotetext{
${ }^{67}$ Martirološki se leksik u Oslobađanju đavola koristio uz lik Židova Davida Baruha, koji najbolje demonstrira položaj (anti)Joba, no Baruh nije predmet ove analize jer nije postavljen u poziciju svjedoka.

${ }^{68}$ Prema Rječniku stranih riječi Bratoljuba Klaića: Vincencije lat. ,pobjednik“( str. 1423).
} 
veže za Božju pomoć. Ime Vicko ili Vice funkcionira kao izvedenica imena Vincencije, s tim da se u latinskome čestica „vice“ stavljala ispred naziva nekih zvanja u značenju ,pod“, „Zamjenik“, „pomoćnik“; Vicko se naime u romanu pojavljuje kao nasljednik, nastavljač Vincenceov, pa ga valja i promatrati u okviru imena Vincencije (v. Lukšić 1996: 170). Ova primjedba Irene Lukšić na temu imena likova - povezivanja Vincenca i Vicka s pobjedom - mogla bi se nadopuniti i suprotnim gledištem: povezivanje s pobjedom ironičnoga je predznaka s obzirom da u vrtlogu povijesti ovi likovi uvijek zadobivaju status gubitnika.

Na sudbinu likova Vincenca i Vicka u tom se smislu najviše naslanja lik Pepa iz Uvoda u tvrđavu, gdje je čitavo jedno poglavlje romana nazvano Muke po Pepu (Josipu) (137 $-159)$.

U Prokletoj ergeli u tom je kontekstu fra Andrija najupečatljiviji nositelj etikete mučenika:

„To bolno stanje duše što se možda jedino na ovoj zemlji događa svetim ljudima kakav je fra Andrija, koji se uvijek, pa i u najstrašnijim svojim mukama, pitaju koliko su sami krivi za vlastitu nesreću.“ (PE: 94, istaknula D. M. L.)

„O svom učitelju i uzoru fra Andriji mučeniku“ (PE: 97, istaknula D. M. L.)

„Možda će u nekoj daljoj budućnosti, piše fra Marko, suze nad zajedničkom sudbinom dvojice bosanskih mučenika u dušama njihovih nasljednika izbrisati sve vrste nametnutih netrpeljivosti.“ (PE: 158, istaknula D. M. L.)

„Uskrsnu zoru dočekao je na koljenima moleći uskrslog patnika da svojim zagovorom umilostivi Svevišnjeg i okonča njegovu golgotu.“(PE: 160, istaknula D. M. L.)

Mnoge stranice Šehovićevih romana ispunjene su naturalističnim prikazima prizora nasilja, mučenja i patnje:

„Fra Vincenco je cijelo vrijeme molio u sebi Boga da mu podari snage, ali čim je izgubio tlo pod nogama, bol u rukama, leđima i ramenima postajao je sve snažniji i strašniji (...) Krvnik je šutke i hladnokrvno, baš kao da radi najbezazleniji posao, 
izvršio kapetanovo naređenje, a zatim na ono 'vira', stao opet okretati kotačem paranka. Ovaj put fra Vincenco je osjećao kako mu se 'meso od kostiju rastaje'.“ (GOD: $18-22)$

„Banuli su u dvor stražari iz grada, izvršili pretres svih prostorija, čak i crkve, naročito pomno pregledavajući knjige i spise, a zatim naredili Vicku da uzme sve svoje pjesme i pođe zajedno s njima u grad. Istog dana, kad su ga doveli u Knežev dvor, oduzeli su mu pjesme i pritvorili ga u sobi za lakše prijestupnike, gdje je proveo dva dana i dvije noći..." (GOD: 141)

„Izmrcvarene mrazom, strahom i tegobnim razmišljanjem, izgone nas iz vlaka kao stoku. Ljudi na konjima s bičevima u ruci, ili zadjenutim za pojas, viču, psuju i zvižde bičevima iznad naših glava. (...) Donose desetak metara dugo čelično uže, stavljaju ga između nas duljinom stroja i svakoga pojedinačno lisicama vežu za nj.“(UUT: 111)

„Naređuju da izlazimo jedan po jedan i kako koji iskoči i dodirne tlo nogama, dvojica 'preodgojenih' grubo mu zavrću ruke odostrag i vežu ih žicom. (...) Ne vode računa o posljedicama i robovi skaču jedan drugome na lice, na trbuh, na grudi, udaraju glavom o donji dio stupa jarbola i onesvješćuju se. (...) Teško se izvlačimo iz živog, zamršenog klupka ljudskih tijela.“ (UUT: 152)

„Kad su ih malo zatim osvijestili, lijevajući po njima hladnu vodu nalivenu iz kamenice za pojenje ispred štale, nastavili su ih tući i ispitivati gdje su skrivene bisage s dukatima. (...) Ljutiti nasilnici nakon premlaćivanja naredili su im da se svuku dogola. (...) Jedan od mučitelja namignuo je časniku i, izvukavši oštri bodež za pojas, zapitao ga je li vrijeme da vide imaju li Turci što skriveno u drobu.“ (PE: 79 - 80)

„U takvim uvjetima nisu mogli opstati ni stjenice ni mali miševi, ali je zato bilo po mjeri crvenih akrepa i velikih miševa koji nasrću na okovane uznike grizući ih za nezaštićene nožne prste.“(PE: 146)

„Tako, jedan za drugim, u tom grotlu raspojasane mržnje i nečovječnosti, prolaze pored nas osuđenici kao Krist na Golgoti. Čekamo sa strepnjom daja Husein-bega. (...) 
Daidža Husein-beg, možda znajući da će se i neko od nas tu naći, unatoč zavezanim rukama otraga i natpisu, kao i drugima, obješenom o vratu psovkama, pljuvanju i čestim udarcima, učinio mi se nasmiješen kao da je u maškarama na dubrovačkom Veljunu, a ne na užasnom križnom putu. (...) Išao je Husein-beg u koloni poniženih nesretnika, uglednih građana, onako velik i uspravan, dok je rulja s jedne i druge strane uskog koridora podivljale mase pljuvala na njega, trgala mu s tijela ostatke odjeće, ostavljajući krvave tragove svojih prljavih noktiju.“(I: 637)

„Dugo se časnik na konju vrzmao okolo izdajući naredbe. Onda je, kao i u prethodnom slučaju, zavladala neka strašna tišina, a zatim pucnji. Husein je vidio kako se moj otac naglo ustao, a odmah zatim pao natraške u rov presahle vododerine.“ (I: 657)

„Prilazeći vratima kuće zapuhnuo ih je reski vonj, a unutra, iz hrpe uglja i pepela virili su neizgorjeli dijelovi ljudskog tijela: ruke, stopala, dio glave i nogu. 'Da smo prije došli, možda bi nekoga i spasili', rekao je tiho Ilijas.“ (I: 903)

Već i ovih nekoliko odlomaka romana reprezentativno je za prikaz količine mučenja kojoj su izravno ili neizravno izvrgnuti protagonisti ovih povijesnih romana. ${ }^{69}$

Osobitost je hrvatskih novopovijesnih romana u odnosu na tradicionalni povijesni roman šenoinskog tipa upravo u isticanju mračnih slika prošlosti, povijesti kao vrtloga patnje, žrtvenosti malih pojedinaca. U tim romanima „opisi torture zauzimaju ono mjesto koje je u Scottovim i srodnim djelima predviđeno za krunidbe, turnire i svadbe“ (Žmegač 1994: 86).

Kao kontrast represivnoj okolini u koju su postavljeni i traumatičnim zbivanjima kojima su podvrgnuti, ostvarena je vanjska i unutarnja karakterizacija Šehovićevih protagonista. Veza između vanjskoga izgleda i unutarnjih osobina likova naglašena je u romanima tradicionalnoga tipa, pri čemu do izražaja dolazi kulturna simbolika (v. Grdešić 2015: 75 - 77).

U Šehovićevim romanima, naime, nailazi se na protagoniste koji su čvrsti, jaki i atraktivni, kako po svojoj fizionomiji, tako i po moralnim kvalitetama.

U kontekstu proživljenih trauma zanimljivo je uputiti na upisanost trauma $\mathrm{u} /$ na stamena tijela $^{70} \breve{S}$ hovićevih likova protagonista.

\footnotetext{
${ }^{69}$ Kao što je već spomenuto, ovakvi će prizori mučenja u Oslobađanju đavola biti vezani za prezentaciju sudbine Židova Davida Baruha, ,čija sudbina je udes drevnog Joba, ali Joba bez pokajanja i bez nade (114)“.
} 
Njihova tijela postaju sam prostor svjedočenja, pri čemu se ,na specifičan način spajaju metafore historijskog i histološkog“(Jukić 2003:150); riječ je o povijesti „,istetoviranoj na tijelima svojih žrtava“ (isto:153), o ljudskom tijelu kao o „kriptičnom historiografskom svitku“ (isto: 152).

Čvrsta, jaka i uspravna tijela protagonista-svjedoka stradavaju od vlage i mraka tamnica u koje su bačeni, od nedostatka hrane i vode, ugriza ogromnih miševa (fra Andrija u PE), udaraca, bičevanja i rendgenskih zračenja s ciljem sterilizacije (Luko i Pepo u UUT)... U Gorkom okusu duše Vicko na samom kraju romana, činom samoubojstva u 65. godini, postaje tek obješeno tijelo ${ }^{71}$.

U Ilijasbegovićima se zaokružuje problematika položaja tijela protagonista-svjedoka, otvorena u Šehovićevu prvome povijesnom romanu Gorak okus duše. Naime, u svojim šezdesetim godinama, nekoliko trenutaka prije nego će počiniti samoubojstvo pucnjem iz pištolja (kao i njegov pradjed Ilijas-beg u 65. godini života), sjedi Ilijas, general-bojnik HVO-a, u hamletovskom ozračju napuštene tvrđave opkoljene neprijateljskom vatrom i razgovarajući s najboljim prijateljem Markom, kojem u nasljeđe ostavlja tek svoju priču:

„(...) sjedio (je) na zidiću (...) s prstima zarivenim u kosu, oborena pogleda, šutljiv i nepomičan kao kip, kao onaj miralaj Hasan-beg na uljanom portretu, kao i njegov otac na Bleiburgu, kako Ilijasbegovići oduvijek izgledaju kada se nađu pred nepreskočivim visokim zidom svojeg kismeta.“ (I: 939)

Ovakvu deheroizaciju protagonista u hrvatskome povijesnom romanu, smještanje $u$ situacije u kojima tjelesno i psihički trpe, pokazuju svoje očajanje pred povijesnim zbivanjima, Mira Sertić (1970: 248 - 252) utvrdila je još u romanu Milutina Cihlara Nehajeva Vuci (1928.) na primjeru kneza F. Krste Frankopana.

\footnotetext{
${ }^{70}$ Usporedi:

- Vicko/Vincenco - „Mladiću, kojem je sada bilo punih osamnaest godina i imao lijep, muški izgled poput ujaka“ (GOD: 30)

- Mavro - „fra Mavro je posljednjih godina naglo otežao, i da nije tako visok, teško bi mu habit sakrio trbuh" (OĐ: 38)

- Pepo /Luko - „Visok i snažan muškarac, sportski građen kao i Luko, fina, malo potamnjela lica i guste kovrčave kose“ (UUT: 131)

-fra Andrija - „Osim što je ta činjenica povezivala Ali-agu i fra Andriju, još jedna im je sličnost bila zajednička: skladnost njihove tjelesne građe (od glave do pete) koja je nedvojbeno izazivala divljenje." (PE: 144)

-Ilijas - „Kada je poslije objeda došla teta Ore i vidjela ga u uniformi, gotovo je zanijemila od ushićenja. Ilijas ju je zagrlio i poljubio, a ona, odmjeravajući ga od glave do pete, reče: 'Ajme, čeljadi, što figura.'“ (I: 776)

71 ,jednog zimskog jutra, u njegovoj šezdeset i petoj godini života, sinovi su ga pronašli obješena u staji“ (145)
} 
Riječ je o romanu u kojem, valja još jednom napomenuti, Julijana Matanović prepoznaje „startnu poziciju hrvatskog novopovijesnog romana“ (1995: 101). Ova autorica naglašava kako je „najsnažniji primjer oslabljivanja jake povijesne osobe opis kneza u prvoj noći njegova zatočeništva:

Pred željeznim vratima stajao je u tmini knez i udarao šakom po gvožđu. Šaka je od strašnih udaraca bila sva krvava, ali željezna se vrata nisu ni potresla - a ni sone strane nije se odazvao nikakav ljudski glas. U gluhoj tišini udarci su odjekivali kao bespomoćna kletva protiv vrata paklenskih (...) Na čelu bila je nabrekla krvava žila, oči se širile kao u ludilu, kosa je razbarušena pala na oči, a na ustima skupljala se pjena. ${ }^{72}$ Takav je opis nezamisliv u čistom povijesnom romanu.“ (2003: 33 - 34).

Ovom prilikom ipak valja uputiti na razlike u prirodi deheroizacije zamjetljive u ovom slučaju na primjeru lika Krste Frankopana i Šehovićevih protagonista.

Prvenstveno, Šehovićevi nositelji fabule nisu povijesno provjerljivi i jaki likovi poput F. Krste Frankopana. Vicko, fra Mavro, Luko i Pepo, fra Andrija i Ilijas povijesno su beznačajni pojedinci, čak i kad nose status mirovnih pregovarača ili vojnih generala. Osim toga, njihova se imena ne mogu ovjeriti u službenim povijesnim zapisima poput imena kneza Frankopana. Drugo, valja uočiti razliku u „skidanju s pijedestala heroja“ (izraz Mire Sertić, v. 1970: 251). Deheroizacija Krste Frankopana vidljiva je prilikom smještaja kneza u privatno, intimno ozračje; „ne prikazuje (ga se) kao nepogrešivog, savršenog heroja, nego kao čovjeka od krvi i mesa, sa svim njegovim manama i vrlinama“" (Sertić 1970: 248).

Dok F. Krsto Frankopan na izoliranost, marginaliziranost i nepravdu reagira gnjevom, buni se, protestira (usp. prethodni citat iz romana $V u c i$ ), u Šehovićeve protagoniste u takvim se situacijama gotovo nečujno uvlači gorčina, ali gorčina bez srdžbe i bijesa, bez nastojanja za aktivnom, glasnom pobunom protiv postojećega stanja.

Šehovićevi likovi najčešće razvijaju autodestruktivne porive te razmišljaju o samoubojstvu (npr. Luko iz Uvoda u tvrđavu ${ }^{73}$, fra Andrijin supatnik Ali-aga iz Proklete ergele ${ }^{74}$ ) ili ga i počine (Vicko iz Gorkog okusa duš $e^{75}$, Ilijas iz Ilijasbegovića ${ }^{76}$ ).

\footnotetext{
72 Julijana Matanović citira odlomak iz romana M. C. Nehajeva Vuci (1928: 47).

73 „Iz ovog paklenog kruga u koji sam zapao, samo smrt me može osloboditi nepodnošljivih bolova duše. Smrt samoubojstvom! Odlučujem se konačno i neopozivo. (...) Gotovo hladno o tom razmišljam i tražim način kako da se dokrajčim." (UUT: 80)

${ }_{74}$ „Fra Andriji se činilo da je Ali-aga čvrsto odlučio umrijeti (...) Odavno je fra Andrija čuo da se smrt najprije useli u čovjekove oči, a iz Ali-agina pogleda zračio je silan prezir prema životu.“ (PE: 147)
} 
Vidljivo je kako represivni mehanizmi vlasti (crkveni, politički) redovito dovode Šehovićeve protagoniste-svjedoke do društvene izdvojenosti i položaja žrtve.

„Žrtvenost“ Šehovićevih likova u pravilu nije visokomimetskoga modusa jer oni ne stradavaju zbog tragičke hamartie, primjerice poput grčkih tragičnih junaka ili kršćanskih mučenika; njihova je žrtva tipična ili slučajna, na njihovom se mjestu mogao naći bilo tko drugi.

Takvu vrstu žrtve Northrop Frye (2000.) povezuje s arhetipskom figurom iz antičke književnosti pharmakos ili žrtveno janje:

„Pharmakos nije niti nevin niti kriv. Nevin je u tom smislu što je ono što se njemu događa kudikamo veće nego što su posljedice ma kojeg njegova postupka (...) Kriv je u tom smislu što je pripadnik društva krivnje; odnosno živi u svijetu gdje su takve nepravde neizbježan dio egzistencije (...) Pharmakos je, ukratko, u položaju Joba.“

Prizivajući motiv Joba, priziva se problematika pravednika koji trpi, s tim da valja ukazati na Jobovu ambivalentnost:

„U proznim dijelovima Job se prikazuje kao strpljiv i ponizan čovjek, vjernik koji besprigovorno prihvaća volju Božju. Naprotiv, u pjesničkim dijelovima (u drami) Job optužuje Boga, buni se, odbija prihvatiti njegovo određenje, protestira, jada se.“ (Vugdelija 1994: 220).

\footnotetext{
75 ,'Bol je trenutan, nešto što dođe i prođe, dok je patnja trajna i beskonačna, neprestano prisutna, jer je ona neprebolna bol'.

Upravo tada, kada su svi njegovi bliži mislili da je sretan i zadovoljan, on dade napisati tu tužnu misao, a malo zatim, jednog zimskog jutra, u njegovoj šezdeset i petoj godini života, sinovi su ga pronašli obješena u staji. Nije ostavio nikakav zapis koji bi pomogao da se odgonetne naprasna misao o samoubojstvu, ali tridesetak njegovih posljednjih pjesama, pisanih također latinskim jezikom, nedvojbeno ukazuju da je riječ o pravom samoubojstvu..." (GOD: 145)

„XXIV. Bilo bi lijepo umrijet večeras, / dok stotine zvona lijeno se klate / i zvone resko brončane molitve. / Raspnite već jednom bezvrijedno mi tijelo, / zar je uopće važno što nijesam kriv.“ (GOD: 155)

${ }^{76}$ „Ilijasovo odlučno odbijanje da pođu mudžahedinima u susret, navodilo ga je i na pomisao da se prijatelj odlučio na samoubojstvo. (...) Sjedio je Ilijas blizu njega (Marka, op. D. M. L.) na stubištu s laktovima na koljenima i prstima zarivenim u kosu i kao po nekom pravilu ukletosti, činilo se da ponavlja gubitnički lik svojih predaka, što su se, poput istih kipova, redali iz stoljeća u stoljeće stazom zamišljenog povijesnog perivoja Ilijasove obitelji. (...) Bez obzira što je cijenio liječnika, Enko je svakako htio pogledati leš i sam se uvjeriti je li rođak Ilijas počinio samoubojstvo ili je ubijen. (...) Na koncu, doktor se još jednom sagnuo i pomirisao oko rane tvrdeći da se još jasno osjeća snažan vonj baruta i spaljene kose, Enko to nije provjeravao, vidjelo mu se na licu da je prihvatio doktorov zaključak, odnosno da postoji samo jedna prostrijelna rana na lijevoj sljepoočnici.“ (I: 939 - 966)
} 
Psihoanalitičkim rječnikom (Lacan) Job zapravo protestira pred velikim Drugim (v. Šimić 2009). Iako od tog velikog Drugog ne dobiva konačan odgovor o smislu svoje patnje, tj. Bog/veliki Drugi ostaje nedohvatljiv, odnos nije narušen; nakon iskušane patnje Jobova je vjera jača i kvalitetnija.

U slučaju Šehovićevih likova može se primijeniti subverzivno iščitavanje Knjige o Jobu: umjesto do jačanja vjere, patnja dovodi do gubitka vjere i nade, do očaja i gorčine. Patnja ne postaje, kao u Jobovu slučaju, sredstvo pročišćenja i poučnosti.

Valja pri tome naglasiti kako se ne preispituje vjera u kontekstu odnosa čovjeka prema Bogu - Šehovićevi romani nemaju za predmet religijska pitanja. Motivom (ne)vjere problematizira se odnos pojedinca prema mehanizmima crkvene vlasti, i to na isti način na koji se propituje odnos pojedinca i političkih struktura moći. U svakom slučaju, riječ je o odnosu malog pojedinca i središta moći.

Jobovska patnja, patnja nevinih, dovodi do sumnje u vrhovne autoritete bilo koje prirode, sumnju u velikog Drugog.

Na tragu prethodnoga, svi Šehovićevi protagonisti-svjedoci primjer su ,žrtvenoga janjeta/jarca" ne samo od strane vanjskih represivnih sustava nego posebno u okviru zajednice kojoj pripadaju (npr. don Vicko iz GOD i fra Mavro iz OĐ te fra Ilija i fra Andrija iz PE nailaze na „okretanje leđa“ svojih franjevaca, a Ilijas i Enko iz Ilijasbegovića svojih Bošnjaka).

Svjesni svoje žrtvenosti, uglavnom postaju svjesni, odmah ili postupno, i besmisla te žrtve. Ipak, Ilijasov deset godina mlađi rođak Enko, posljednji izdanak loze Ilijasbegovića iz istoimena romanesknoga ciklusa, od preostalih se navedenih likova razlikuje upravo po tome što ističe smisao vlastite žrtve.

„Provodeći u tamnici Scheveningenu možda i posljednje godine života kao osuđenik za ratne zločine po zapovjednoj odgovornosti“ (I: 1002) Enko piše svoje Zapise, a fragmentom iz njegovih zapisa, koje je „u pero govorio“ fra Petru, a koje će objaviti Ilijasov prijatelj Marko, zaključeno je i zaokruženo petoknjižje o Ilijasbegovićima.

Iako svjestan položaja ,žrtvenog jarca“ (I: 994), Enko je, po modelu grčkih tragičkih junaka i kršćanskih mučenika, ,'umiranje od' prekodirao u 'umiranje za'““ (Assmann 2011: 106), pri čemu, za razliku od ostalih protagonista-svjedoka u Šehovićevim povijesnim romanima, postaje martir/mučenik u pravome značenju te riječi budući da je ,žrtva političkoga nasilja kojem fizički podliježe dok istovremeno simbolički trijumfira“ (isto): 
„Nedužan sam kažnjen za grijeh koji mi se pripisuje jer sam ga kao čovjek osudio i kao zapovjednik pokušao krivce kazniti, kako je to od mene zahtijevao ne samo ratni zakon već i moja ljudska savjest na koju, hvala ti Bože, nikada nisam zaboravljao... Ne robijam zato što su me njihovi optužili, još uvijek obuzeti otrovom mržnje i želje za osvetom, već zato što su neki naši, uništili dokaze o mojoj nevinosti. (...) Znao sam da me žrtvuju...

Sve sam znao pa ipak dragovoljno krenuo pred haaški tribunal jer davno sam odlučio žrtvovati se za Bosnu i Bosance...(...) Ma kako sudili o mojoj žrtvi, ne držim je besmislenom.Vjerujem da će se ostvariti dugi san o državi Bosni. Ako sam imalo tome pridonio, a Alah će mi posvjedočiti da jesam, moja žrtva imat će smisla i ne samo moj narod, po dobru će me pamtiti...

A ti, fra Petre, brate moj po tuzi i gorčini, objavi svoje Zapise neka se uvjere pokoljenja da smo se žrtvovali za njihovo dobro, za istinu, za našu Bosnu...“ (I: 1002 1003)

U odnosu na Enka kao primarnog svjedoka - martira/mučenika, fra Petar postaje sekundarni svjedok - martirijum, a oboje se uklapaju u prostor tzv. religijskoga svjedoka s obzirom da je riječ o ,radikalnoj inverziji političke podređenosti u religijsku nadređenost, traume u trijumf“" (v. Assmann 2011: 106).

Naravno, u Enkovu bi se slučaju spomenuta „religijska nadređenost“ odnosila na bezuvjetnu vjeru u Bosnu, a ne u Boga kao instancu u okviru religijske ideologije u užem smislu. Ipak, na metaforičkoj razini, odnos fra Petra kao sekundarnog svjedoka prema Enkovoj muci mogao bi se usporediti s položajem evanđelista prema muci Kristovoj ili položajem Katoličke Crkve prema ubijenim kršćanskim mučenicima (v. Assmann 2011: 107).

Iako i za izgradnju drugih likova-svjedoka Šehović upotrebljava martirološki leksik (muka, mučenici, golgota...), oni, za razliku od Enka, ne predstavljaju mučenike u okviru maloprije iznesenog religijskoga svjedočenja jer svjedočenje o njihovim patnjama ne podrazumijeva smislenu žrtvenost, povjerenje u „nadmoćnog boga za kojeg vrijedi umrijeti“ (Assmann 2011: 108).

Njihova se žrtvenost može promatrati u okviru onoga što A. Assmann (2011.) naziva moralnim svjedokom, onom čija ,poruka (...) odgovara negativnom otkrivenju, u čijoj prirodi nije da uspostavlja smisao pa time ni utemeljujuću povijest na kojoj se mogu zasnivati zajednice“ (108). 
Ako je, dakle, patnja u Šehovićevim povijesnim romanima u pravilu (ako se izuzme primjer Enka) povezana s nevjerom, beznađem, gorčinom i besmislom - u čemu se može vidjeti njezin smisao unutar idejnog sloja tih romana? Signifikantno je da „smisao“ patnje protagonisti romana redovito pronalaze upravo u samom svjedočenju te patnje, po načelu pa(m)titi - svjedočiti (pisano,usmeno).

Ontologija svjedočenja zasniva se, kako je to u početnome dijelu ovoga rada već izneseno, na apelu moralnoj zajednici kao neučesničkome adresatu, nudeći testimonijalnome iskazu stanovito odbacivanje tereta konstativa/istinitosti u zamjenu za performativnu snagu, odnosno moć (moralnoga) djelovanja samim iskazom.

\subsubsection{Odnos prema književnosti}

Za karakterizaciju protagonista-svjedoka iznimno je važna njihova „lektira“ i odnos prema literaturi. Šehović po tome pitanju kao književne reference uglavnom odabire prepoznatljiva imena hrvatske i svjetske književnosti, a čija djela može dovesti u vezu s idejnim slojem svojih romana.

Vjerska (a i svaka druga) isključivost fra Vincenca iz Gorkog okusa duše podcrtana je preferiranjem djela protuturske tematike - Marulićeve Judite i Pjesme suprotive Turku (36), a neodobravanjem povijesnoga djela Ludovika Crijevića Tuberona „Svojstva i običaji Turaka, gdje pisac čak hvali i uzdiže neke turske vrline (kao da oni mogu imati ikakvih vrlina!)“(16). Upravo je po književnome ukusu i potpunoj neisključivosti fra Vincencu suprotstavljen lik njegova nećaka don Vicka, koji je ,radije čitao Katulove i Tibulove stihove negoli žitija svetaca i kršćanskih mučenika“ (72).

Vickova je lektira predstavljena kao podloga njegovoj neisključivosti:

„Uvjerio se (Vincenco, op. D. M. L.), kao i u slučaju Tuberona, da pjesništvo i veliko znanje otupljuju moralnu i duhovnu oštricu kršćanina, čineći ga nesposobnim da se suprotstavlja neprijatelju“ (72). 
Lik kontroverznoga pjesnika fra Mavra Sarake iz Oslobađanja đavola građen je na odnosu prema Johnu Miltonu i njegovoj poemi Izgubljeni raj:

„Inkriminirana pjesma bila je zapravo poema 'Oslobađanje đavola', a u kojoj pjesnik Mavro, po uzoru na svog velikog učitelja Johna Miltona, opisuje pretkazani potres u gradu.“" (35)

Kao fra Mavrovi književni utjecaji javljaju se još i Moliereov Mizantrop i Corneilleov Cid:

„Cid mu se dopao zbog jasne antiapsolutističke ideje, a u riječima Mizantropa prepoznao je vlastite poglede na književnost. (...) Po prirodi otvoren do ciničnosti, fra Mavro je svojim sugrađanima pjesnicima savjetovao, služeći se riječima Mizantropa: 'da jedan čestit čovjek uvijek mora znati, oduprijeti se želji da se pera lati'.“(36)

Ludovik Crijević Tuberon, osim u Gorkome okusu duše, spominje se i u Prokletoj ergeli, i to u kontekstu problematike historiografije - kako pisati objektivno o povijesnim događajima. Naime, fra Ilija (protagonist prvoga dijela romana), bosanski fratar obilježen svojom težnjom istinitosti i objektivnosti te neisključivošću (čime funkcionira kao antipod fra Vincencu iz Gorkog okusa duše), objavio je knjigu o ovom dubrovačkom filozofu i povjesničaru uvjeren kako je riječ o

„prvom kršćanskom piscu koji u opisivanju povijesnih događaja (poput Krbavske bitke s Turcima) dosljedno slijedi istinitost okolnosti i zbivanja, ističući u svom stavu 'iskustvo učenog povjesničara', a ne vjersku, narodnu ili stalešku pripadnost"“ (12).

U završnome dijelu dubrovačke trilogije - u Uvodu u tvrđavu, kao i u Ilijasbegovićima, pitanja utjecaja književnosti kulminiraju u poznatom načelu Oscara Wildea kako ,život oponaša umjetnost mnogo više nego što umjetnost oponaša život"“ (2009: 33) jer „stvari jesu stoga što ih mi vidimo, a što vidimo i kako to vidimo ovisi o umjetnostima koje su na nas utjecale“ (34).

U svakodnevnim životnim situacijama protagonisti Uvoda u tvrđavu Pepo i Luko, obojica intelektualci sa završenim studijem književnosti, prepoznaju mjesta literature, život vide kroz umjetnost, pri čemu su najfrekventnije reference na djela Marina Držića (Dundo Maroje, Skup) i F. M. Dostojevskog (Braća Karamazovi). 
Kad u Auschwitzu preda nj jedan SS-narednik postavi poslužavnik pun suhomesnatih narezaka, sira, kruha i vina, Luko vidi prizor iz slavne Držićeve komedije Dundo Maroje: „Kakva trpeza, sjetih se našeg starog, dobrog Pometa.“ (58)

Nakon što mu u ruke dospije paket Pepovih rukopisa, Luko osjeća da u rukama drži bogatstvo i ponaša se poput Držićeva Skupa (194).

„Star sam vam ja, grintav i nemoćan kao Skup“, ponavlja Luko u svojim dnevničkim bilješkama (243).

Ugledavši u moskovskome zatvoru istražitelja Aljošu, Luko se odmah sjeti Aljoše Karamazova (107), a jednoj ruskoj sobarici pokušava prići „malo grublje, kako bi to recimo učinio Mića Karamazov“(100).

Jedno od poglavlja u romanu nosi naslov „Tamo gdje je robovao Dostojevski“ (161), a Pepov sin dobiva ime Feđa - po Fjodoru Mihajloviču Dostojevskom (90),

Uz Držića i Dostojevskoga, prisutna su pozivanja na Tolstoja, Dantea, Ivana Gorana Kovačića...

Ruska zima doživljena je kao ona iz Tolstojeva Rata i mira (99), a devet etapa u Sibiru kao devet krugova Danteova Pakla $(110$ - 114).

Prilikom boravka u specijalnom logoru Jadwiga Pepo u šali kaže da je njemu i Luki suđeno preživjeti taj pakao ,jer bi inače ovaj svijet ostao bez ovovjekog Dantea“ (81).

Scenu na Golom otoku Pepo vidi kao sliku iz Jame Ivana Gorana Kovačića (152).

Književno stvaralaštvo prati Ilijasa, centralni lik Ilijasbegovića, i to od njegovih najranijih dana (od drugoga dijela trećeg romana ciklusa pod imenom Begovina) preko dječaštva i mladosti (u Dubrovačkome intermezzu) do zrele dobi (u Od Mostara do Den Haaga), stoga je njegova karakterizacija neodvojiva od književnih predložaka na koje se referira.

Još kao dječak čitao je teti Hasniji ulomke iz Zagorkine Gričke vještice te Tolstojeve Ane Karenjine, a volio je i stripove iz Politikina zabavnika.

Ilijasov otac Enver-beg, osnivač muslimanskoga kulturno-umjetničkoga društva Gajret, omogućio je Ilijasu da od najranije dobi bude „uronjen“ u svijet kazališnih dasaka.

Stvaralaštvo Marina Držića (Dundo Maroje, Skup) predstavlja neiscrpno inspirativno vrelo i u ovome slučaju. Ilijas u raznovrsnim životnim segmentima, poput Luke i Pepa u Uvodu u tvrđavu, prepoznaje mjesta literature, npr.: 
„Nas trojica (Luko, Rasko i ja), po savjetu roditelja, ali i vlastitim shvaćanjem da se moramo 'akomodavati zlu vremenu', ozbiljno smo se trudili da nas drug Braco zapazi i pohvali...“(634)

„Zaboravljamo što je bilo i zaokuplja nas to što jest. Marin Držić bi rekao 'veći dinar manjega pokriva'.“(638)

„(...) nisam osjećao grižnju savjesti što potvrđujem jednu laž. (Kako kaže dum Marinov Bokčilo: 'Kad se laže nek se laže.') Ni stari Bokčilo nije te riječi izustio zato što je lažov.“ (662)

I Ilijasove predožbe o Dubrovniku razvijaju se na podlozi književnih slika velikih Dubrovčana Marina Držića i Ivana Gundulića:

„Ilijas je odmah primijetio da u Zagrebu nije bilo velike razlike između dojma koji je dobio o licu grada i dojmu o licima njegovih žitelja, naravno onih s kojima se družio. Nije mu se učinio kao Dubrovnik, koji je oduvijek doživljavao kao mladu i bogatu ljepoticu, silom udanu za stara i ružna muža (kao onog iz Gundulićeve 'Dubravke'). To 'poniženje ljepote', zbog čega ga je, nakon referata o Gundulićevoj 'Dubravci' u petom razredu, zapanjeni profesor mjesecima proganjao dokazujući mu kako možda ima pravo 'ako Grad gleda u vremenu feudalne, kapitalističke i fašističke vladavine', a da gotovo neoprostivo griješi tvrdeći da je on takav 'u socijalističkoj domovini'.“" (728)

„Odavno su ga (Ilijasa, op. D. M. L. ) prestale ljutiti neke osobine sugrađana shvativši konačno da u ponašanju tih ljudi ima nešto što je jednostavno neotklonjivi dio njihova bića. Ustvari, to je ono na što iz dubina stoljeća upozorava veliki Držić - neizmjenjiva i trajna vladavina bahatosti niska duha zbog koje je morao, svoj voljeni Grad, zauvijek ostaviti na milost i nemilost vladajuće uskoće.“(845)

Iako je, želeći slijediti djeda Ilijas-bega, Vojna akademija bila njegov prvi izbor, Ilijas na poticaj okoline odlučuje s prijateljem Markom studirati književnost.

Postavivši svog protagonista u književne akademske krugove, Šehović mu je osigurao mjesto za reakciju na novonastale socrealističke tendencije: 
„više su učili od starijih kolega negoli od profesora poznatih imena koji su sada, iz straha od vlasti, prigrlili 'sveta načela socrealizma', lako i bezočno se odričući svojih 'buržoaskih zabluda' o književnosti.“ (729)

Razočaran socrealističkim pristupom književnim djelima, Ilijas se povlači u prostor sveučilišne knjižnice gdje „neopterećeno“ proučava autore koji su „službeno ili neslužbeno bili zabranjeni i prozvani reakcionarnima“ (730): Dostojevskoga, Čehova, Hemingwaya, Huxleya, Kafku, Tina Ujevića, A. B. Šimića, a posebno Miroslava Krležu i Ivu Andrića.

Šehovićevi protagonisti-svjedoci uvijek su povezani s pisanjem: nekad je riječ o pjesnicima (don Vicko, fra Mavro, Pepo) ili općenito piscima u najširem značenju te riječi (Andro, Luko, fra Ilija i fra Andrija, Ilijas).

Osim toga, povezani su s književnim stvaralaštvom bilo kao knjižničari i prepisivači u samostanskim knjižnicama (Vincenco, Mavro, Andro), studenti književnosti (Luko, Pepo, Ilijas) ili sveučilišni profesori književnosti (Luko).

Šehović preko likova svjedoka problematizira i određena pitanja vezana za književnu produkciju, prije svega poticaj na književno stvaralaštvo, poetička načela te recepciju književnih djela, odnosno njihov društveno-povijesni aspekt.

U tome se kontekstu ističu psihemske figure Vicko (GOD), fra Mavro (OĐ) i Pepo (UUT), u čiji je značenjski krug postavljena sociemska sastavnica ,pjesnik“.

Na tome tragu svaki od romana dubrovačke trilogije kao žarišnu točku posjeduje paracitatni književni zapis, koji je u cijelosti unesen u roman (Gorak okus duše) ili se na njega kontinuirano samo poziva (Oslobađanje đavola, Uvod u tvrđavu).

U Gorkome okusu duše riječ je o Vickovoj zbirci od 25 pjesama, u Oslobađanju đavola o fra Mavrovoj poemi Oslobađanje đavola, a u Uvodu u tvrđavu o Pepovoj drami Tvrđava:Biblija za nevjernike.

Značaj ovih fiktivnih rukopisa za Šehovićev romaneskni svijet ogleda se i u činjenici što se naslovi romana ove novopovijesne trilogije referiraju upravo na njih. I dok naslovi Oslobađanje đavola i Uvod u tvrđavu to izravno sugeriraju, za Gorak okus duše treba napomenuti da je riječ o jednome od stihova iz Vickove zbirke pjesama:

„Samo očajanje, strava noći, obuzetost nečim i gorak okus duše.“ (151, istaknula D. M. L.) 
Književno djelovanje prikazano je kao rezultat potrebe da se pjesničkim sredstvima svjedoči o pretrpljenoj patnji. Tako Vickovih 25 pjesama uobličuje gradacijski niz od slutnje beznađa i očaja do preplavljenosti gorčinom do te mjere da se ne vidi izlaz osim u samoubojstvu. U odgonetavanju Vickovih samoubilačkih misli pripovjedač se u Gorkome okusu duše poziva upravo na njegove pjesme kao „dokazni materijal“ budući da one

“nedvojbeno ukazuju da je riječ o pravom samoubojstvu, snažne rijetke ličnosti, s dubokim osjećajem ugroženosti i saznanjem da ono što je želio sačuvati nije imalo nikakvih šansi, nije imalo budućnosti“ (145).

Za razliku od Vicka, koji demonstrira slom pjesničke ličnosti pod traumatskim iskustvima koje donosi izvanpoetska zbilja, Pepo svojom dramom Tvrđava: Biblija za nevjernike donosi primjer nadvladavanja traumatskoga iskustva.

U svojim svjedočenjima Pepov prijatelj Luko navodi kako tijekom mučenja u specijalnom logoru Jadwigi „Pepo u šali kaže da je nama dvojici suđeno da preživimo ovaj Pakao, jer bi inače ovaj svijet ostao bez ovovjekog Dantea“" (81).

Ideja o pisanju drame rađa se u Pepu za vrijeme boravka u sibirskom logoru:

„Kaže mi da u svemu ovome ima mnogo tragičnog i ponavlja da će o svemu tome napisati dramu, o kojoj mi je već govorio. Već je, kaže, ima u glavi, a naslov će joj biti Biblija za nevjernike. U rijetkim slobodnim časovima sve češće mi govori o svojoj zamišljenoj Bibliji.“(116)

Preživjeti da bi se pisanjem svjedočilo o proživljenome - postaje ne samo Pepov, već i Lukin imperativ. Dok će Pepo na traumatska zbivanja odgovoriti dramskom riječju, Luko će nakon preživljavanja objaviti Kroniku ropstva te Zapise iz Sibira, tekstove koji su u romanu etiketirani kao literatura svjedočenja, a napisani s ciljem „da se ne zaborave strašne ljudske patnje“"(176).

I fra Andrija, protagonist drugoga dijela Proklete ergele, na pretrpljene će patnje odgovoriti zapisima pod geslom „,da se ne zaboravi“. 
Dok je nevin godinama boravio u bosanskoj tamnici, držala ga je nada da će jednom o svojim patnjama pisano svjedočiti, da će „napisati knjigu o Prokletoj ergeli, velikom i sramnom zločinu, kojega je Europa lako prešutjela““(149).

U posljednjim rečenicama svojih zapisa ističe važnost istinitosti zapisa, ali i neizbježan pritisak cenzure:

„Dobro je i potrebno piscu da sam prođe čovjekovu golgotu kako bi je što vjernije opisao. Ja sam je doista prošao, ali da bi to vjerno opisao, morao bi kao pisac sve reći, a ne samo ono što mi je dopušteno.“(166 - 167)

Priroda umjetničkoga djela i s njome povezana određena poetička načela problematizirana su u okviru dijaloških oblika (izravni ili prepričani dijalozi pjesnikasvjedoka s drugim akterima) te onih monoloških (različite vrste zapisa pjesnika-svjedoka).

Čak i u logorskim prostorima Pepu i Luki osigurano je svojevrsno književno okruženje s obzirom da su im pridruženi likovi litvanskoga pjesnika Maironisa i teoretičara strukturalizma Klausa Beckera. Ovi likovi komentiraju suvremenost Dostojevskoga upravo u poglavlju s naslovom „Tamo gdje je robovao Dostojevski““.

Za jedno od značajnih pitanja književne teorije - odnos svijeta fakcije i fiktivnoga svijeta - može poslužiti Leibnizov model „mogućeg svijeta“.

Ova kategorija obuhvaća hipotetične svjetove fikcionalne proze, a u njezinu se temelju nalazi odnos sumogućnosti ili komposibilnosti (v. Peleš 1999: 153 - 180). „Mogući svijet nije oponašanje stvarnoga svijeta, već jedna od potencijalnih varijanti kako bi nešto moglo biti.“ (Peleš 1999: 163).

Reakcija kritike na Pepovu dramu Tvrđava povod je da Luko kao lik svjedok /pripovjedač kroničar Raul Mitrovich iznese komentar koji proizlazi upravo iz spomenutoga modela mogućih svjetova. Priziva se pritom i poznatu Aristotelovu razliku između povijesti (ono što se zaista dogodilo) i književnosti (ono što bi se moglo dogoditi) (v. Aristotel: 2005: 21), ali, primjerice i pogled Milana Kundere na roman (i književnost općenito) kao prostor kojim se propituje ljudsko postojanje, a ,postojanje nije ono što se dogodilo, postojanje je područje čovjekovih mogućnosti““ $(2002: 43)^{77}$ :

\footnotetext{
77 „Romanopisci iscrtavaju kartu postojanja otkrivajući ovu ili onu čovjekovu mogućnost. No ponavljam: postojati, to znači 'biti-u-svijetu'. Valja, dakle, shvatiti $i$ lik $i$ njegov svijet kao mogućnosti. (...) Vjernost povijesnoj zbilji svejedno je sporedna u odnosu na vrijednost romana. Romanopisac nije ni povjesničar, ni prorok: on je istraživač postojanja.“ (Kundera 2002: 43 - 44)
} 
„Luko ne vidi u kritikama toliko ni neznanja ni zlonamjernosti, koliko nesposobnosti da proniknu u jedan mogući svijet. I ja mislim da se radi najviše o pogrešnom pristupu komadu, ne samo pojedinih kritičara, nego i kazališta, koji u komadu gledaju nešto što se stvarno dogodilo, dokumentarnu sliku, a ne vide da se zapravo radi o nečemu što se može dogoditi, o jednom izmišljenom svijetu koji je zahvaljujući snazi riječi postao stvaran i moguć.“ (UUT: 247)

Moguće je povući paralelu spomenutoga citata i pripovjedačeva komentara na inkriminiranu poemu Mavra Sarake u Oslobađanju đavola, a u kojem do izražaja dolazi jedno od osnovnih načela umjetničkoga stvaranja - uzdizanje pojedinačnoga iskustva na univerzalnu razinu:

„A upravo to pošto-poto prepoznavanje suvremenika u njegovu djelu bilo je nešto što je fra Mavro smatrao najstrašnijim plodom primitivna duha (...). Jer, pišući djela, uvijek je pogledom išao daleko preko granica svoje zemlje i dalje od svoga vremena, u svijet i budućnost.“(35)

Od mjesta koja obiluju sličnim metapoetskim iskazima valja izdvojiti jedan od paracitatnih zapisa u Uvodu u tvrđavu : Pepovu Poslanicu prijatelju piscu (91 - 92), pisanu u stilu „renesansne poslanice kao prostora poetičko-estetičkih iskaza“( (v. Fališevac 2008: 7 - 25). Čitava poslanica zbir je savjeta piscima, od kojih se na području pravila pjesničkoga oblikovanja mogu izdvojiti zahtjev za očuđenjem (,,jer prava snaga pisca / i jest u tome / da obično čini neobičnim“) i svijest o intertekstualnosti svakog teksta (,Neka je u tebi / vječno osjećanje / da to što pišeš / netko već davno / mnogo bolje od tebe / napisa“").

Uvod u tvrđavu dotiče se, između ostaloga, i lakog i teškog pisanja kao popularne postmodernističke opreke (216).

Svi Šehovićevi povijesni romani obuhvaćaju i problematiku recepcije književnih djela, odnosno njihovo smještanje u određeni povijesno-društveni kontekst. Ovime se, među ostalim, otvara i uvijek aktualno pitanje odnosa pisca i vlasti, a o čemu će biti govora u narednom potpoglavlju rada, koje se tiče odnosa likova svjedoka prema ideološkim strukturama. 


\subsubsection{Odnos prema ideološkim strukturama ${ }^{78}$}

Odnos likova svjedoka prema ideološkim strukturama, koje su u Šehovićevim romanima predstavljene političkim i religijskim centrima moći, sagledat će se u okviru ontemske figure (ne)vjerovanja te u kontekstu sociemskih opreka vlast i pisac.

Prema ideologiji likovi svjedoka mogu se razdijeliti u dvije oprečne skupine -vjernici i nevjernici. Konstruirani su na način da, bez obzira na početnu poziciju (vjerovanje ili nevjerovanje), većina likova u određenome trenutku fabularnoga razvoja dobiva etiketu ideološkoga nevjernika.

Vjera/nevjera likova očituje se u njihovim postupcima, razmišljanjima (posebno važna uloga dijaloga i zapisa kao monoloških iskaza) te izravnim definicijama ekstradijegetičkogaheterodijegetičkoga pripovjedača, koje se kombiniraju s generalizacijama i vrijednosnim sudovima.

Kako je već spomenuto, u svakom romanu Šehovićeve dubrovačke trilogije javlja se po jedan par likova svjedoka preko kojih je zahvaćena kategorija (ne)vjerovanja: fra Vincenco - don Vicko (Gorak okus duše), fra Mavro Saraka - sudac Andro Menčetić (Oslobađanje đavola) i Luko - Pepo (Uvod u tvrđavu).

Karakterizacija se u slučaju navedenih parova likova zasniva na analogiji među likovima, odnosno prisutna je recipročna karakterizacija (izraz Rimmon-Kenan 2002:70, navedeno prema Grdešić 2015: 83) s obzirom da usporedba po nekoj referentnoj točki (ovdje je to odnos prema ideološkim dogmama) donosi suprotna svojstva članova para. ${ }^{79}$

\footnotetext{
${ }^{78}$ Vrijednosno neutralno značenje pojma ,ideologija“ (skovao ga je 1796. Antoine Destutt de Tracy) odnosilo bi se upravo na ono što sam pojam etimološki sugerira - znanost o idejama (v. Ravlić 2001: 148).

Iako su društveno prisutnije negativne konotacije ovoga pojma, nova shvaćanja vide ideologiju kao „sučelje između društvene strukture i društvene spoznaje“, ona je „osnova društvenih predodžbi koje dijele pripadnici neke skupine“ (van Dijk 2006: 21)

U ovome doktorskome radu sam termin ,ideologija“ i iz njega izveden pridjev ,ideološki“ odnosi se na političku ideologiju budući da je upravo taj aspekt ideologije prepoznat kao funkcionalan u Šehovićevim povijesnim romanima, s naglaskom na negativnome aksiološkome predznaku.

U slučaju udruživanja ideologije i političkoga djelovanja / političke moći, nerijetko na percepcijskoj razini stupa na snagu vrijednosno negativna uporaba pojma ideologije. Politička je ideologija vezana uz ,nastojanje da se interesima osigura prevlast u javnosti i političkome procesu" (Ravlić 2001: 148), a na tome putu "ideologije mogu razvijati negativne identitetske strategije, kao što su diskriminacija, netolerancija i uklanjanje drukčijega“ (isto: 154).

${ }^{79}$ Recipročna je karakterizacija redovito prisutna u romanima Dostojevskoga te se, primjerice, četvorica braće Karamazova mogu uspoređivati na temelju odnosa s ocem (Rimmon-Kenan 2002:70, navedeno prema Grdešić 2015: 83).

Za ovaj je rad zanimljivija ontemska figura vjerovanja u Braći Karamazovima: Aljošino kršćansko vjerovanje i Ivanovo bezbožništvo (v. Peleš 1999: 254 - 261).

Upravo su Dostojevski i njegova djela najučestalija književna intertekstualna točka u Šehovićevu Uvodu u tvrđavu.
} 
Na početku fabularne linije Vincenco, Andro i Pepo određeni su slijepom vjerom u ideološke mehanizme (Vincencova uvjerenost u opravdanost vjerske isključivosti i povjerenje u crkvene strukture; Andrina uvjerenost u pravednost i nepogrešivost vlasti Dubrovačke Republike; Pepova zaslijepljenost komunističkim idejama), dok su Vicko, Mavro i Luko uglavnom izuzeti bilo kakvog ideološkoga sljedbeništva, dakle obilježeni su nevjerovanjem u središta moći utemeljenima na ideološkoj isključivosti.

U svjetlu ovakve polarizacije,Vincenca, Andru i Pepa, s jedne strane, i Vicka, Mavra i Luku, s druge strane, može se promatrati kao „likove sinonime“ (Bal 2000: 104), s tim da je, kako među „vjernicima“, tako i „,nevjernicima“, moguće uočiti „,razlike u okviru kvalifikacije u stupnju i modalitetu“, pri čemu se polarna skala transformira u kliznu skalu (Bal 2000: 104).

Luko iz Uvoda u tvrđavu jedini je među navedenim likovima svjedoka koji ne doživljava nikakve pomake po pitanju (ne)vjerovanja: on je od prve do zadnje stranice romana ,apsolutni nevjernik“ (80). Ostali su likovi karakterizirani manjim ili većim pomacima od kategorije vjerovanja do nevjerovanja.

Vincenco, koji je cijeloga svojeg života bio obilježen „fanatičnom odanošću ideje za koju se borio“ (GOD: 25), kojem je „,sve izgledalo neznatno i sićušno prema velikom i svetom Svjetlu ideje, koja ga je cijeloga života poprilično zasljepljivala“ (25), pred kraj života, donkihotovski umoran, izjavljuje: „Vicko, nadu sam izgubio!“ (95).

Iako je Vincenco predstavljen kao Vickov mladenački uzor, kod Vicka se vrlo brzo, odmah po izlasku iz samostanskih zidina u okrutnost vanjskoga svijeta, uočavaju ogorčenje i beznađe koji ovaj lik prate sve do čina samoubojstva.

Fra Mavro, „prokleti pjesnik“ iz Oslobađanja đavola, „nekad je s velikim zanosom vjerovao u neke političke, društvene ideje, a sada u sve to duboko i beznadno sumnja“"(37). Kao takvome nije mu jasno kako njegov prijatelj sudac Andro kao

\footnotetext{
Iako se u Šehovićevim romanima, posebno Uvodu u tvrđavu, uočava pojava različitih glasova svjedoka i sukoba ideja (vjerovati / ne vjerovati), nije riječ o polifoničnim romanima u onome smislu kako polifoniju Mihail Bahtin tumači na primjeru romana F. M. Dostojevskoga. „Dostojevski sve vidi kao koegzistentno, jedno uz drugo, istovremeno, u prostoru, a ne vremenu“ (prema Bahtin 2000: 30); ,njegovi junaci nemaju biografije, ničeg se ne sjećaju; sjećaju se iz prošlosti samo onog što još uvijek doživljavaju kao sadašnjost“ (31); „proturječnosti kod njega nisu postajale dijalektičke, nisu se kretale na putu vremena, po nizu koji postaje, već stoje jedno pored drugoga“"(32).

U Šehovićevim je romanima prisutan razvoj misli, njihova vremenska obuhvaćenost. Iskustva, a posebno ona traumatska, dovode sve Šehovićeve likove svjedoka do idejnoga jedinstva: odbacivanja svih ideoloških dogmi i isključivosti.
} 
„pametan čovjek svjesno robuje zabludama politike i ideologije svoje klase, što nije u stanju da kao i on raskrsti sa zabludama. (...) A gospar Andro je tek po navršenoj četrdesetoj godini počeo sporo i bolno obračunavati sa samim sobom.“ (54)

Za razliku od Lukina dosljednoga bezvjerništva, Pepo je skoro čitavoga života pripadao „sljedbenicima vjere koja se zove Partija“(153). Pepovo je odbacivanje svih ideoloških okova umjetnički osvjedočeno paracitatnom poslanicom u kojoj se „U ime patnje ljudske, istine i svetog / razuma“"(5) obraća prijatelju L. B. (Luki Božidareviću, op. D. M. L.).

Ova se poslanica nalazi na početku Uvoda u tvrđavu, a njezin sadržaj, posebno završni dio, mogao bi funkcionirati kao motto ovoga romana, ali i kao tematsko-idejno žarište cjelokupne Šehovićeve romaneskne produkcije povijesne tematike:

„Tebi, dosljedni bezvjerče. Dopusti / bar da nije sve bilo zaludu u ovom / jadnom stoljeću, jer ako ništa / drugo, mnoge je moralo uvjeriti u / neke vjekovne zablude.“ (5)

Dok je u dubrovačkoj trilogiji figura (ne)vjerovanja u bilo kakve ideološke strukture, odnosno pozicije moći, zahvaćena najvećim dijelom preko recipročne karakterizacije parova likova, u Prokletoj ergeli i Ilijasbegovićima ${ }^{80}$ do izražaja dolazi odnos centralnoga lika prema užoj ili široj lepezi likova, čime je analognost zamijenjena lančanim ili disperzivnim prikazom.

U liku fra Andrije kao žarišnoga lika Proklete ergele, realiziran je pomak od apsolutne vjere njegova prethodnika i učitelja fra Ilije do krajnje nevjere Ali-age, Andrijina supatnika u bosanskome zatvoru.

Situacija se usložnjava činjenicom da je fra Andrijin nastavljač, mladi fra Marko, opet postavljen u položaj vjernika, jednako kao i fra Andrijin prethodnik.

Iako je od strane crkvenih krugova zbog svojih stavova o snošljivosti među vjerama i narodima (iznesenih u pisanim djelima i govorima) fra Ilija bio percipiran kao heretik i izdajnik, zbog čega završava na određeno vrijeme i u splitskoj tamnici, ovaj lik nije obilježen gorčinom i sumnjom u svete ideale za koje je živio:

\footnotetext{
${ }^{80}$ I u prva tri dijela Ilijasbegovića zamjetni su parovi likova svjedoka: Ilijas-beg i fra Matija (Ilijas-beg, kapetan trebinjski), Hasan-beg i Enes (Inšallah), Ilijas-beg i fra Ivan Lovrenović (prvi dio Begovine), ali njihova se poveznica ne zasniva, između ostaloga, i na opreci vjerovanja-nevjerovanja kao u slučaju dubrovačke trilogije, već se njihov odnos prvenstveno temelji na zajedničkim predodžbama o Bosni (jedinstvo Bosne, interkulturni dijalog, neisključivost...).
} 
„Naviknut na svijet prijetvornosti, neiskrenosti i udaljenosti od izvorna Kristova učenja, fra Ilija nije previše uzimao k srcu svu tu podlost i laž koja ga je okružila. (...) Vjernici su u zanosu slušali fra Ilijine riječi o miru i razumijevanju među ljudima koje je svetac Franjo Asiški držao dragocjenim ljudskim vrlinama.“ (42)

S druge strane, nezaslužen boravak u tamnici u bimbaši Ali-agi prouzrokovao je krajnju ogorčenost i gubitak nade:

„Iscrpljen, bolestan i nepravdom ogorčen, Ali-aga se nije mogao suzdržati, što je nekoć znao i mogao, shvaćajući s kim i kakvom vlašću ima posla. Potpuno se predao vulkanu svoje gorčine iz kojega su kuljale užarene psovke na Carstvo i pašaluk, na gramzivu, podlu i podmitljivu vlast.“ (146)

Izdržavajući besmislenu kaznu skupa s Ali-agom, fra Andriji je u početku ovakav prijateljev stav „neprihvatljiv, gotovo bogohulan“ (149), da bi se postupno i u njega uvukao gubitak vjere i „mimo njegove volje, rasla plima gorčine, ponekad mu preplavljujući razboritost $\mathrm{i}$ praštanje“" (159).

Kao u slučaju protagonista-svjedoka iz dubrovačke trilogije, fra Andrija postupno, zaista sitnim pomacima u karakterizaciji, prelazi put od vjere do apsolutnoga bezvjerja, koje kulminira na samome kraju romana kad je pogled „u sliku Krista visoko iznad oltara“ (173) zamijenio „pogledom uprtim u plavo nebo poviše planine“ (173), na kojoj se potpuno osamio i izolirao od svoje franjevačke braće.

Želeći opravdati fra Andrijinu sumnju i udaljavanje od franjevačkoga reda, njegov nasljednik fra Marko u svojim zapisima nastoji razjasniti koliko su tamnovanje u zloglasnoj Kuli i zločini u Prokletoj ergeli obilježili fra Andrijinu ličnost, pri čemu, unatoč svim zločinima i traumama gotovo optimistično najavljuje „neku dalju budućnost““, u kojoj će možda

„suze nad zajedničkom sudbinom dvojice bosanskih mučenika u dušama njihovih nasljednika izbrisati sve vrste nametnutih netrpeljivosti““(158).

Najkompleksnije preobrazbe u kontekstu ontemske figure (ne)vjerovanja prolazi Ilijas, protagonist najvećeg dijela sage o trebinjskoj lozi Ilijasbegovićima. Njegovu (ne)vjeru u 
ideološke mehanizme valja promatrati dvojako: na podlozi sudbine i uvjerenja njegovih predaka (generacijski), ali i u okviru njegovih individualnih transformacija.

Lik Ilijasa karakterizacijski izrasta na podlozi njegova rodoslovnoga stabla: 1.davnoga pretka Ilijas-bega, kapetana trebinjskoga iz 17. st.; 2. Hasan-bega iz 18. st.; 3. djeda Ilijas-bega (suton Austro-Ugarske Monarhije - vrijeme Prvoga svjetskog rata) te 4. oca Enver-bega (događanja vezana uz Drugi svjetski rat).

Svi članovi ovog generacijskoga niza, izuzev Ilijasova oca Envera, simboliziraju nevjeru u ideološke strukture moći koje se zasnivaju na ekstremizmu i isključivosti. Pri tome se kao najveći protivnik svih ideologija, kakvog god predznaka bile, ističe Ilijasov djed.

„Dedo Ilijas-beg koji se ježio na samu riječ komunizam i jedno vrijeme prestao nabavljati Krležine knjige, jer je čuo da se spanđ'o s komunistima“ (473), upozoravao je svoga sina Enver-bega, „zaguljenog starčevićanca“ (459) na opasnost svih ideologija.

Ilijas-beg je vjerovao samo u Bosnu i Bošnjake, smatrajući kako ne postoji politička struja koja bi Bošnjacima promijenila gubitničku narav kismeta:

„A i meni su često govorili da sam njihovo cvijeće... Sine, shvati to s cvijećem, samo je novi način našeg zatiranja... Spaho je pametniji od tebe - ne vjeruje ni jednima ni drugima, kako i treba, jer nas podjednako ne vole...“"(477)

„Uzaludno ga je dedo upozoravao da na sudbonosnim raskršćima valja biti vješt u prepoznavanju znakova za puteve i stranputice. Dedo je znao da se u životu mora 'naučit plivati' i pritom budno paziti da nas vrtlozi silovite rijeke vremena ne povuku u bezdane zabluda.“(575)

U galeriji likova Šehovićevih povijesnih romana upravo Ilijas-begov unuk Ilijas najslojevitije prezentira problematiku (ne)vjerovanja. Osim što ga po tom pitanju valja promatrati u okviru ideoloških svjetonazora njegovih predaka, čitatelju je osiguran pregled Ilijasovih ideoloških stavova doslovno od najranijeg djetinjstva do smrti (samoubojstvo u 60im godinama života).

Totalitaristički režimi predočeni su fingiranjem naivne dječje perspektive, zbog čega Dubrovački intermezzo obiluje scenama dječje zbunjenosti pred „velikim pitanjima“: Tko su masoni? (564) Što su to rasni zakoni? (580) Čemu služe radni logori? (590) itd. 
Pod utjecajem očevih simpatija prema pavelićevskim idejama i povjerenjem u novu državu u kojoj će Bošnjaci napokon ostvariti svoj „tisućgodišnji san“(539), mali Ilijas raduje se pobjedi Nijemaca u Drugom svjetskom ratu:

„Priznajem, valjda pod utjecajem oca, jedva sam čekao kada će se ratnici njemačkog Reicha, Švabe, pojaviti na Stradunu. Doista sam to nestrpljivo očekivao, poglavito od dana kada mi je jedan od očevih prijatelja poklonio mali kukasti križ, od metala zlatne boje i s pribadačom za pričvršćivanje na odijelo.“(564)

U novoj državi NDH otac Enver-beg dobiva važno mjesto u strukturama vlasti (u okviru ministarstva), a Ilijas se entuzijastično priključuje dubrovačkoj Ustaškoj mladeži.

Čitav Dubrovački intermezzo slikovit je prikaz izmjene ideoloških boja u vremenu vezanom za Drugi svjetski rat. U tom je kontekstu reprezentativna slika mase na Stradunu koja tijekom vremena s istim oduševljenjem dočekuje pobjednike povijesnih zbivanja, bez obzira na ideološki predznak, čime se još jednom upućuje na zajednički nazivnik svih ideologija, kao i na neizbježnu cikličnu narav povijesti. Prilikom ulaska partizanskih odreda u Grad,

„Stradun je bio pun gradske čeljadi, isto, ako ne i mnogo više, kao onda_ (istaknula D. M. L.) kad su dolazili Talijani i Nijemci ili kad su ono neposredno poslije proglašenja Nezavisne države svečano defilirali ustaše i domobrani. Kao i prije, (istaknula D. M. L.) narod je nabijen s obje strane Straduna, iza crte plitkih odvodnih kanala, pljeskao pobjednicima. Uzvikivali su: 'Živjeli!', a mnoge žene i djevojke mahale su buketima cvijeća bacajući ih na postrojene partizane.“(619 - 620)

Saznavši za stradanje svoga prijatelja Melvija u Auschwitzu, Ilijas doživljava otrježnjenje od nacističkih ideja:

„Nisam plakao, osjećao sam gorčinu (istaknula D. M. L.) i silno mrzio okrutne ubojice, naciste. Sramio sam se svojeg dječjeg zanosa...“ (650)

I povjerenje u novu državu temeljenu na ,bratstvu i jedinstvu“ s vremenom se pokazalo samo kao još jedna ideološka zabluda u nizu: 
„Razumio sam ih, govorile su (mama i teta Ore, op. D. M. L) nešto što sam davno čuo od tetke Hasnije koja je to nazivala 'našim kismetom'. Ipak me čudilo što se to nastavlja u novoj državi gdje se naizgled dokida utjecaj vjere, koju tako napadno zamjenjuju sa svetošću bratstva i jedinstva svih, i gdje je netrpeljivost među narodima i vjerama zakonski proglašena strogo kažnjivim grijehom. Činilo mi se da se konačno ukida naš grijeh vjerskog otpadništva u čemu sam vidio osobito svijetlu stranu vladavine komunizma. Činilo mi se, kažem. (istaknula D. M. L.)“(654)

Priča koju vozač Husein kao svjedok očeve pogibije na Bleiburgu donosi pred Ilijasa dodatan prijezir prema svim ideološkim ekstremima.

Ipak, u ovakvome otrježnjenju Ilijasovo se ideološko klupko ne odmotava, kako je to bio slučaj u prethodnim Šehovićevim romanima, gdje je figura (ne)vjerovanja svoju kulminaciju dosezala upravo u trenutku protagonistova obračuna s vlastitim ideološkim zabludama i napuštanjem istih. Klupko se peripetijski zamršava Ilijasovim makevijalističkim činom: s ciljem da postane student toliko željenoga Vojnog fakulteta, učlanjuje se preko tete Refike u Partiju. Ilijas naglo napreduje u vojnim strukturama pa vrlo brzo postaje i časnikom Jugoslavenske armije.

Prilikom napada na Dubrovnik 90-ih Ilijas je, kao i prijatelj mu Marko, napustio JNA i priključio se obrani Dubrovnika. Prelazi u HVO (Hrvatsko vijeće obrane) te postaje generalbojnik.

Budući da je proveo neko vrijeme u Švicarskoj, u Mostaru su Ilijasa mediji proglasili izdajnikom vlastitoga naroda, suradnikom Udbe te lažnim domoljubom.

Nakon što su neki pripadnici HVO-a počinili masakr nad bošnjačkim civilima u jednom bosanskom selu, Ilijasu su upućeni prigovori od strane njegovih Bošnjaka jer se i nakon zločina počinjenih u HVO-u nije povukao iz te vojne strukture.

Iako u spomenutim zločinima ni na koji način nije sudjelovao jer je u to vrijeme bio u nekoj vrsti kućnoga pritvora i bez obzira što je te zločine istraživao i oštro osuđivao, Ilijas je, poput svojih predaka, percipiran kao izdajnik „svojih“.

Značajni su posljednji trenutci Ilijasova života, koje provodi opraštajući se s prijateljem Markom u bosanskoj tvrđavi opkoljenoj mudžahedinima.

Dosegnuvši posljednje granice boli nakon što je zbog ideoloških valova kojekavih predznaka izgubio ženu, dvojicu sinova te bio i sam proglašen izdajnikom, Ilijas vidi izlaz jedino u činu 
samoubojstva, čime je obistinio navještenje proročice koja je Ilijasovu majku (tijekom vožnje vlakom) upozorila da će joj sin dići ruku na sebe kao što mu je i djed učinio.

„Okrenuo se i zapitao prijatelja: 'Ne vjeruješ da se u ovome životu i svijetu neki slučajevi neminovno ponavljaju?'“(943)

Okusivši tijekom života „gorak okus“ svih ideologija, Ilijas kao lik zorno demonstrira njihov zajednički razorni karakter, čime se uvjerljivo pridružuje gubitničkoj galeriji svojih predaka, ali i svim protagonistima Šehovićevih povijesnih romana.

U ontemskome nizu Šehovićevih romana uočljivo je i suprotstavljanje dvaju načela: 1) živjeti prema pravilima, tj. biti uklopljen u prosječnost i 2) tražiti vlastiti put, tj. ,stršiti““. Prvi se svjetonazor ili Pelešovim terminom ,ideologemska pojedinačnost“ (1999: 278), vezuje uz sociemsku figuru , strukture vlasti“, a drugo uz sociemsku figuru „pisac“ (u najširem značenju).

Sukob među navedenim ontemima, a time i sociemima, ponajviše je realiziran preko psihemskih figura Vicko, Mavro i Pepo kao predstavnicima pjesničkoga djelovanja.

Svaka moć istodobno podrazumijeva i otpor, napominje francuski filozof Michel Foucault, s tim da ni moć ni otpor ne podrazumijevaju ideju centara, žarišta:

„uvjet mogućnosti moći ... ne treba tražiti u prvotnom postojanju neke središnje točke“, „moć nije institucija i nije struktura, ona nije stanovita sposobnost kojom su neki obdareni; ona je naziv što se pridaje nekoj složenoj strategijskoj situaciji u danom društvu“, a s tim u skladu „,ne postoji jedno mjesto velikog Odbijanja - duša pobune, žarište svih buna“ (Foucault prema Biti 2002: 20 - 22).

Uzevši u obzir ova Foucaultova promišljanja o moći i otporu, valja istaknuti kako će se termini koji u sebi utjelovljuju ideju centara/točaka moći, odnosno otpora (npr. strukture moći, mjesto otpora i sl.) koristiti u okviru shematičnosti, s ciljem što zornijeg prikaza sukobljenosti spomenutih ontema i sociema.

U Šehovićevim se romanima kontinuirano, bilo pozicijom ekstradijegetičkogheterodijegetičkog pripovjedača bilo intradijegetičkoga-homodijegetičkoga pripovjedača, upućuje na povezanost umjetnika i neprosječnosti / „stršenja“: 
a) U Gorkome okusu duše ova veza posebno dolazi do izražaja u dijalogu mladog Vicka sa zrelim pjesnikom Ivanom Gučetićem (110 - 113; 136 - 137) koji mu prenosi ideju slobode umjetničkoga stvaranja zbog koje će često dolaziti u sukob s vladajućim zakonima društva:

„Odavno mu je bilo jasno da društvo svojim pisanim i nepisanim zakonima propisuje granice svoga podanika i njegove dopustljive oblike. Sve je to vrlo precizno određeno, pa i neznatnim odstupanjem podanik postaje čovjek sa suvišnom osobinom koji se ne uklapa u šemu vladajućeg pogleda na svijet i proglašava se odviše drukčijim, neprihvatljivim, neprijateljskim, nepodobnim i tome slično.“ (136)

b) „U njemu (misli na Mavru, op. D. M. L.), kako bilježi sudac Andro, živi ona smjelost tragača za neznanim, koju posjeduju samo istinski nadareni pjesnici, što ga neminovno dovodi u sukob s vladajućom prosječnošću duha. On se pokušava oprijeti toj sili svojom riječi, jasnom i ljudskom, što nagriza okove sputana duha, pravom pjesničkom riječi, melemom za očajnike. Poezija je za njega samo ono što ima trajnost i veličinu blistavih zastava.“ (OĐ: 105)

c) „Pisac zaista mora imati ne samo svoju osobnu politiku, nego i državu, da bude sam država i da se brani od nasrtaja porobljivača uma.“ (UUT: 186)

„Baš na osnovi Pepova djela (posebno 'Tvrđave') zaključio sam da je umjetnost po prirodi elitistička (...) Samo onaj koji se odvojio od mase, oslobodio i osamostalio, koji promatra iz daljeg tu masu, u stanju je pouzdano ocijeniti pravac njezina kretanja, odbacujući, naravno, krajnosti suđenja kao osobinu plitka uma.“(UUT: 234)

Dok se Pepovo dramsko djelo Tvrđava ( kao i Lukini zapisi o logorskim iskustvima) mogu promatrati u okviru problema književne kritike koja je više ili manje u određenim vremenima sljubljena uz strukture vlasti (pa isto djelo kudi ili uzdiže, ovisno o vladajućem mehanizmu), likovi pjesnika don Vicka (GOD) i fra Mavra (OĐ) demonstriraju jedno od važnih obilježja koje Michel Foucault pridaje funkciji-autor, a koja je neizostavna upravo u 
području književnosti kao komunikacijskome činu. Riječ je o diskursima kao objektima aproprijacije (prisvajanja), zbog čega dolazi i do kaznene aproprijacije:

„Tekstovi, knjige, diskursi počeli su dobivati stvarne autore (različite od mitskih likova ili velikih sakraliziranih ili sakralizirajućih figura) u mjeri u kojoj je autor mogao biti kažnjen, odnosno u mjeri u kojoj su diskursi mogli biti transgresivni.“ (2015b: 47 - 48)

Vicko i Mavro demonstriraju situaciju sukoba s ideološkim strukturama (crkvene i političke prirode) te kaznenoga progona kao rezultata poetskoga djelovanja koje se razotkriva kao „čin smješten u bipolarno polje svetoga i profanoga, dozvoljenog i nedozvoljenog, religioznog i blasfemičnog“ (Foucault 2015b: 48), ono je ,gesta nabijena rizicima“ (48).

Svećenik Vicko dolazi u sukob s dubrovačkim biskupskim ordinarijatom jer se njegova poezija, pretežno svjetovne tematike, prepuna očajanja i gorčine, percipira kao čin kojim se „omalovažavaju osnovni temelji Kristove nauke; u njoj nema Božje nade ni ufanja, nego je sve prepušteno demonskoj sili koja vlada na zemlji“(GOD:146).

Vickove pjesme, koje su mu i oduzete, postale su najčvršći dokaz njegove krivnje; optužen je za antikršćanske i heretičke poglede.

Fra Mavro dijeli Vickovu književnu sudbinu; pritvoren je zbog poeme kojom je navodno uvrijedio vlast Dubrovačke Republike:

„Inkriminirana pjesma bila je zapravo poema 'Oslobađanje đavola', u kojoj pjesnik Mavro, po uzoru na svog velikog učitelja Johna Miltona, opisuje pretkazani potres u gradu. (...) Puna finih ironičnih aluzija, mnogoznačna i neuhvatljiva, (...) davala je mogućnost da se doslovnim prevođenjem simbola prepoznaju u njoj živi ljudi iz vrhova vlasti.“(OĐ: 35)

„Ali vlast, tumačio je, (Mavro, op. D. M. L.) živi u neprestanom strahu da je sve što od nje ne potječe upereno protiv nje, da je opasno za društvo i vrijedno samo teške osude.“( (OĐ: 40)

U kontekstu knjige/pisanja kao opasnosti valja uputiti i na slučaj fra Andrijine knjige u Prokletoj ergeli, koji zorno demonstrira bulgakovski motiv „rukopisa koji (ne) gore“. 
Fra Andrijina knjiga o njegovu učitelju fra Iliji našla se na indeksu papinskog Svetog oficija, zbog čega je spaljeno njezinih 14 primjeraka, ali jedan je primjerak ipak bio sačuvan:

„Gvardijan fra Luka morao je ostati dok se posljednja stranica raskomadanih knjiga nije pretvorila u pepeo. Zagledan u oganj 'Božje pravde' kako su zvali lomače, nekoliko puta kao da je čuo potmulo cviljenje spaljenih knjiga, kao daleki plač ugrožene djece.

$\mathrm{Na}$ koncu ove priče fra Andrija je samo uzdahnuo i tiho promrmljao:

-Da je bar moj primjerak ostao!

Gvardijan je ustao i poveo ga do svoje škrinje za knjige. Škrinja je bila puna i, nakon što je izvadio posljednju knjigu, fra Luka ga pozva bliže. Podigao je lažno dno svoje škrinje ispod kojega je s još nekim nepoćudnim knjigama bila i fra Andrijina, koju je fra Luka bio dao na čitanje nadstojnici ženskog samostana gdje se fra Andrija liječio i tako ju, eto, spasio.“(PE: 108)

Navedeni primjeri kreiraju obrazac neizbježnog poraza umjetnika/pisca u sustavima koji se temelje na ideološkoj isključivosti bilo koje vrste. U takvim je sustavima redovito dogmatsko iščitavanje umjetnosti, dakle „kodom policijske istrage“ ${ }^{\text {(81. }}$. Analizirajući povijesni roman Ivana Aralice Psi u trgovištu, Cvjetko Milanja ukazuje na odnos umjetnosti i vlasti koji je prepoznatljiv i u spomenutim primjerima Šehovićevih romana:

„Kako je političko Pismo upravljačko pismo, pismo koje je ujedno i proizvođač povijesti, a književno Pismo - kada nije htjelo biti samo puki podržavalac, u cijeni, i sluškinja političkome Pismu, a tekst romana to upravo briljantno pokazuje, dolazilo je vazda s rubova, izvana, s margina, pa je per definitionem po sili svojega književnog digniteta moralo biti subverzivno i osporavateljsko - zato je političko Pismo u svakoj prilici kad nije moglo 'ispeglati' književnu diskurzivnu praksu tu istu uklanjalo, eliminiralo, brisalo.“(1984: 253).

Osim što tematsku okosnicu Pasa u trgovištu predstavlja razotkrivanje mehanizama vlasti ukazivanjem na tragične posljedice koje politika ostavlja na sudbinama svih likova ( a što je

\footnotetext{
${ }^{81}$ Izraz Cvjetka Milanje u radu: Arabeska kodova, Forum XXII., br. 10 -11, Zagreb, 1984.
} 
preokupacija većine suvremenih hrvatskih povijesnih romana), upečatljivo tematsko-idejno Žarište ostvaruje se upravo u odnosu umjetnika/pisca i vlasti.

Aralica je sukob političke i umjetničke riječi prezentirao sudbinama Sulejmanovih sinova Mustafe i Džihangira: obojica stradavaju zbog dogmatskoga iščitavanja tekstova.

Mustafa u svojoj knjizi Rasadnik plemenitih vještina donosi „Priču o vladaru žitnoga polja“, kojom alegorijskim putem čini što i Aralica svojim romanom u cijelosti - razotkriva surovost mehanizama vlasti, pri čemu se „,na unutardijegetičkoj razini preslikava izvandijegetički pedagoški odnos pripovjedača prema čitatelju“ (Biti 2005: 202).

Ključnu sliku u ovoj Mustafinoj/Araličinoj paraboli zauzima popularna slika sječe „klasova koji strše $\mathrm{e}^{\text {(82 }}$.

I Džihangirove pjesme (koje je Aralica kao paracitate ugradio u tkivo romana korištenjem kurziva kao grafičkim rješenjem) postaju liku Uhvanu Jusufu, prototipu državnoga poslušnika, poligon za dogmatsko iščitavanje poezije. U tome kontekstu Araličin didaktički nastrojen sveznajući pripovjedač iznosi komentare koji funkcioniraju na metapoetskoj razini, primjerice:

„Bože, što li Uhvan od pjesme može učiniti. (...) Istina je da je Uhvan svođenjem
pjesničkog jezika na politički govor, unakazio pjesmu. I njemu samom odvratno je
gledati čerečenje stihova. Siječeš i razvrstavaš, ovo je but, ovo je krilo, ovo čeljust. A
pogotovo odvratno kad od rastavljenih dijelova sastavlja novo značenje, pa ne uspije
sastaviti cjelinu i pred sobom ugleda beznogo ili bezglavo stvorenje ..." (Aralica 2004: 304)

Stihovi pjesama poslužili su Uhvanu Jusufu kao izravni dokazi Džihangirovu potpomaganju Solunske pobune usmjerene protiv Sulejmanove vlasti, temeljem čega Džihangir svoj život okončava u tamnici osamljene kule.

\footnotetext{
${ }^{82}$ „Ubrzo je zapazio da Trazibul mačem ne mlatara. Meta su mu klasovi ječma koji strše iznad ostalih, ponekad za cijeli pedalj, oni klasovi koji su, zahvaljujući bogzna kakvoj snazi uspjeli izrasti veći od svoje mnogobrojne subraće, oni koji su se izdigli iznad većini zadane visine.“ (Aralica 2004: 12)

U svojoj doktorskoj disertaciji Julijana Matanović „odnos pojedinaca i moderatora povijesti“ (1998: 291) u novopovijesnoj varijanti hrvatskoga povijesnog romana, između ostaloga, slikovito prezentira i pozivanjem na odlomke iz romana Ivana Aralice i Nedjeljka Fabrija. Paralelizam Araličinoj paraboli „Vladar žitnog polja“ Matanović vidi u odlomku Fabrijeva Vježbanja života gdje Emilijina baka Mafalda siječe ivančice: „,...uzima srp u desnu ruku, zagazi jednom nogom (a bila je obuvena u gumene čizme) među ivančice što su, pod zidom, slijedile krivudanje strme ulice, i poče ih sjeći. Strigla je, tako, do u dno vrta, do na kraj zida pa se ponovo vratila odakle je počela. Dvije stabljike, čudom preživješe prvu košnju. Ali padoše naknadno. Kod provjeravanja osta li koja neposječenom.“ (Fabrio 1985: 364 prema Matanović 1998: 291).
} 
Iako suvremeni hrvatski povijesni romani (primjer Šehovića i Aralice) upućuju na neizbježan slom beskompromisnih umjetnika prilikom susreta s razarajućim mehanizmom ideologije, njihove umjetnine (tekstovi) predočene su kao „transhistorijska vrijednost ${ }^{\star 63}$ koja uspijeva opstati u vrtlogu povijesne zbilje.

Za razliku od Aralice i Šehovića, koji (na tragu spomenutih primjera) moć književne riječi suprotstavljaju rušilačkom karakteru povijesti/vlasti/politike, Nedjeljko Fabrio na stranicama svoje Jadranske trilogije (Vježbanje života, 1985; Berenikina kosa, 1989; Triemeron 2002) na isto mjesto postavlja glazbenu umjetnost. (Njegov je Lucijan, između ostaloga, nositelj svjetlosti glazbe u mraku povijesnog ludila.)

I Ludwig Bauer će, primjerice, u svome novopovijesnome romanu Kratka kronika porodice Weber (1990.) glazbenu umjetnost (uz mostogradnju) tretirati kao transhistorijsku vrijednost oponiranu političkome zlu što se ponavlja generacijama Webera.

Odnos umjetnika i politike Fabrio će ipak najeksplicitnije demonstrirati likom slikara Alfreda iz Triemerona. Riječ je o liku koji u svome umjetničkome radu odbija podilaziti političkim zahtjevima; ne želi da njegova umjetnina predstavlja apologiju nacionalnoga mita i kolektivne sreće:

„Čak su mi dva puta ponudili da slikam kolektivnu sreću. Prvi put u Titovoj Jugoslaviji, a sada ognjištari u Tuđmanovoj Hrvatskoj. A ja sam oba puta to odbio. (...) Umjesto u kolektivnoj sreći, ja živim po svojoj savjesti.“ (Fabrio 2002: 71 - 72)

Bijeg od političke zloporabe umjetnosti, a time i od njezine trivijalizacije, Alfred vidi u (uzaludnom) pokušaju bijega od povijesti.

Mada se na prvi pogled može činiti da Šehovićevi likovi pisaca, posebno pjesnika, funkcioniraju kao heroji-žrtve s obzirom da su konfrontirani protivnicima (ovdje mehanizmu vlasti), ali ih ne svladavaju (prema Bal 2000: 109), ovi likovi bitku dobivaju ne na individualnome planu, već na univerzalnome planu budući da

\footnotetext{
${ }^{83}$ Komentirajući strukturu moralnosti u hrvatskome novopovijesnom romanu, Cvjetko Milanja dovodi je u vezu s tzv. transhistorijskim vrijednostima poimajući ih kao „ono za što se isplati živjeti i za što povijest ima smisla“ budući da je riječ o vrijednostima koje ,idu 'uz' čovjeka, a ne politiku, pa dakle i uz onu pozitivniju stranu povijesti“; to su čovjekove „kulturne vrijednosti, njegovi zanati i umijeća, njegova umjetnost i umješnost“ (1994: 1088).
} 
„Šehović (...) eksplicitno vjeruje da samo književni zapis i s njim povezani nerv svjedočenja mogu u povijesnom trajanju kompenzirati zlo dnevne politike, zlo nasilja i ciničnost svake vlasti““ (Novak 2004: 220).

Šehovićevi romani potvrđuju povlačenje ideje povijesti kao učiteljice; na njezino mjesto postavljena je književnost, koja za razliku od svoje prethodnice, može poučavati tek o nemogućnosti poučavanja.

Na samome kraju ovoga potpoglavlja odnos sociema vlast i pisac sagledat će se unutar okvira parezije, i to onako kako je vidi francuski filozof Michel Foucault.

Foucault prvi o pareziji ne govori na razini retoričke figure nego na razini diskursa definirajući je kao govornu djelatnost (prema Brnčić 2014: 182).

Etimološki parrhesia označava djelatnost koja se sastoji u tome da se kaže sve (pan rema), što bi značilo da je parezijast onaj koji kaže sve, gdje izraz „reći sve“ znači reći istinu ne skrivajući je bilo čime (Foucault 2015a: 19).

Prema Foucaultu parezija je jedan od modaliteta istinitog govorenja ${ }^{84} \mathrm{u}$ kojem

„subjekt govoreći tu istinu koju označava kao svoje mnijenje, svoju misao, svoje vjerovanje, preuzme nekakav rizik (...) Valja započeti, ustvrditi i suočiti se s rizikom da povrijedimo drugoga, da ga razdražimo, naljutimo ga i kod njega izazovemo neka ponašanja koja mogu postati čak i izuzetno nasilna“ (isto: 20).

Parezija je stoga za Foucaulta označena sintagmom „hrabrost istine“.

Šehovićevi se protagonisti-svjedoci u svome djelovanju prezentiraju kao parezijasti s obzirom da pred sebe postavljaju zadatak govorenja istine unatoč riziku, pri čemu se „istinito“ podudara s Foucaultovim četirima značenjima/oblicima u kojima se, prema kojima, i zbog kojih nešto može nazvati istinitim: pojam istine viđen je kao neprikriven (istinito je ono što nije skriveno, zataškano), nepomiješan (istinito je ono što ne prima nikakav dodatak ili dopunu, što se ne miješa ni sa čim drugim osim samim sobom), ispravan (istinito je ono što je sukladno s onim što valja) i nepokvarljiv (istinito je ono što postoji i ostaje onkraj bilo kakve promjene) (2015a: 189 - 190).

\footnotetext{
${ }^{84}$ Foucault govori o četiri temeljna modaliteta istinitoga govorenja, odnosno o četiri nositelja takvoga govorenja: prorok, mudrac, onaj koji podučava (profesor, nastavnik, tehničar), parezijast (v. 2015a: 23 - 36).
} 
Između ostaloga, u Šehovićeve je likove svjedoke-pjesnike (don Vicko, fra Mavro, Pepo) ugrađena ideja o dužnosti pisca da svjedoči istinu svoga vremena (v. OĐ: 55) s obzirom „da je pisac, možda jedini u ovoj masi nevinih stradalnika, koji je jedini u stanju sve ovo vidjeti i osjetiti na pravi način“(UUT: 111).

Nesreće i patnja kojima su izloženi transformiraju se u inspiracijski impuls, pokretač umjetničkoga odgovora na povijesnu zbilju. Likovi književnika tako, unatoč riziku od sukoba s ideološkim strukturama, književnim sredstvima „svjedoče istinu svoga vremena“.

Foucault upravo područje umjetnosti vidi kao prostor koji je nužno ispunjen parezijskim djelovanjem budući da

„sama umjetnost (...) mora sa zbiljom ustanoviti odnos koji više nije iz reda ukrašavanja, iz reda oponašanja, nego koji je iz reda ogoljivanja, razotkrivanja, čišćenja, iskapanja, silovitog sužavanja na osnovno postojanje““(164).

Nadalje, u kontekstu parezije simboličan je naslov zapisa jednoga od protagonistasvjedoka. Riječ je o fra Ilijinu (protagonist prvoga dijela Proklete ergele) nedovršenom rukopisu o vlastitome životu pod nazivom De omnibus aut nihil, aut veritas ${ }^{85}$, a što bi u slobodnome prijevodu značilo „O svima ništa, ili istinu“ ${ }^{\text {(86 }}$. Upravo bi ovaj naslov, parezijskoga predznaka, mogao predstavljati geslo djelovanja svih Šehovićevih protagonistasvjedoka s obzirom na njihovu težnju izricanja svoje istine, bez ostatka.

Iako se istinu nerijetko povezuje sa zbiljom, a time zapravo i izvanjezičnom/izvantekstualnom stvarnošću, valja podsjetiti kako je istina uvijek povezana s izricanjem, iskazivanjem, dakle istina se „ustaljuje kroz jezik i u jeziku“(Agamben 2004: 36), slikovito rečeno - proizvodi jezikom.

\footnotetext{
${ }^{85}$ „Ako je pokojni fra Ilija i za čim žalio, mislio je fra Andrija, bio je to njegov tek započeti rukopis posljednje knjige pod naslovom De omnibus aut nihil, aut veritas (u prijevodu O svima ili ništa, ili istinu), u kojoj je, po svoj prilici, kanio opisati cijeli svoj život i posebno odnos Europe prema Bosni i franjevačkoj braći, a najviše vlastite muke i poniženja koja je doživljavao od europske braće po vjeri, braneći ljudska načela svetoga Franje, te čast i ponos bosanskog franjevca." (PE: 48)

${ }^{86}$ Znakovito je uputiti da Šehović sintagmu ,,aut nihil aut veritas“ (ili ništa ili istinu) koristi i u romanu Oslobađanje đavola prilikom navođenja djela fizičara Luke u fusnoti:

„U svojoj kraćoj raspravi „Aut nihil aut veritas“ L. M. De Pozza proriče buduće potrese u gradu Dubrovniku i najbližoj okolici..." (OĐ: 12)

Zanimljivo je da se podrijetlo izraza „De omnibus aut nihil, aut veritas“ („O svima ili ništa, ili istinu“) intertekstualno naslanja na jedan od prizora Čehovljeve prve drame „Drama bez naslova“"“Platonov“, u kojem glavni lik Platonov parafrazira poznatu latinsku izreku „De mortuis aut bene, aut nihil“ (O mrtvima ili dobro ili ništa) u spomenuti oblik:

„GLAGOLJEV 1. De mortuis aut bene aut nihil, Mihajlo Vasiljiču!

PLATONOV. Nije tako...To je latinska hereza. Po mome je: de omnibus aut nihil, aut veritas. Ali bolje veritas, nego nihil, poučnije je u krajnjoj liniji...Pretpostavljam da mrtvi ne traže ustupke.“(1960: 20, istaknula D. M. L.)
} 
Parezija se zasniva na „podudaranosti osobnog uvjerenja parezijasta $\mathrm{i}$ istine onoga što govori“ (Brnčić 2014: 182), stoga u parezijskom nastupu

,istinitost govornik jamči vlastitom osobom i ne odnosi se ponajprije na sadržaj iskazanoga nego na kakvoću odnosa govornika i onoga što govori - parezijast iskazujući istinu na određen način je, zapravo, proizvodi“ (isto), „na neki način sâm potpisuje istinu koju iskazuje, veže se za tu istinu, i posljedično se obvezuje na nju i njome“ (Foucault 2015a: 20).

Na temelju dosadašnjega izlaganja može se primijetiti korespondentan odnos subjekta $\mathrm{i}$ istine u slučaju figure parezijasta i figure svjedoka: istina parezijasta neodvojiva je od njega na isti način na koji je istina svjedočenja neodvojiva od samoga svjedoka.

Kao što je „fokalizacija svjedočenja apsolutno singularna“ (Derrida prema Bekavac 2015:75), tako je i čin parezijasta temeljen na njegovu vlastitom uvjerenju da je ono što govori istina.

„Ni parezija ni svjedočanstvo nisu tek govorni činovi, nego činovi koji potvrđuju izvana čovjeka u njegovoj nutrini (...) Svjedokov angažman kao i angažman parezijasta ključni su za smisao njihove djelatnosti koja se temelji upravo na kvaliteti njihova angažmana.“ (Brnčić 2014: 202).

Postavivši svoje protagoniste u položaj svjedoka i istaknuvši njihove parezijske intencije, Šehović i na ovaj način ideju apsolutne i jedinstvene Istine, koja se čvrsto skriva u velikim službenim povijesnim dokumentima, zamjenjuje ,istinama“ fluidno pozicioniranima u subjektivne prostore, nepodložnima klasičnoj verifikaciji, a utemeljenima isključivo na odgovornosti i povjerenju, kako svjedoka, tako i njegova adresata. 


\section{DOKUMENT}

\subsection{Dokument u povijesnome romanu}

S obzirom da je i za povjesničara i za pisca povijesnoga romana prošlost uvijek dostupna samo preko svojevrsnih tragova prošlosti (v. Hutcheon 1988), u oba slučaja nezaobilazan je odnos prema dokumentu. Pri tome je sam pojam dokumenta u svome izvornome značenju vezan za dokaz, potvrdu, primjer (Zlatar 1998: 124), ali u postmoderno vrijeme poprima mnogo širi dijapazon značenja.

Iz toga će razloga ovo potpoglavlje biti usmjereno na osobitosti „funkcioniranja historiografskoga sloja“ (Milanja 1994) u tradicionalnoj i suvremenoj varijanti povijesnoga romana, kako u okviru stranih književnosti, tako i na području hrvatske književnosti.

U odnosu prema povijesnoj građi tradicionalni povijesni roman obilježen je težnjom povijesnoj autentičnosti, u smislu što vjernije (re)konstrukcije prošlih zbivanja. Zato je važno da ,povijesni realemi“ uvedeni u tekst ne budu u suprotnosti sa službenom verzijom povijesti, te da se izbjegavaju sve vrste mogućih anakronizama (McHale 1987: 87 - 88).

$\mathrm{Na}$ tragu rečenoga, pisci klasičnih povijesnih romana morali su osigurati dugotrajne pripremne radnje koje su podrazumijevale iscrpno izučavanje povijesnih zapisa. Tako je, primjerice, August Šenoa (19. stoljeće), ,ne samo tvorac hrvatskoga povijesnog romana nego i njegov najistaknutiji predstavnik“" (Sertić 1970: 254), u predgovorima svojih povijesnih romana nastojao upućivati čitatelja na trud koji je morao biti uložen prije procesa samoga pisanja, tj. prije fikcionalizacije prošlosti:

„Premećući u arhivu grada Zagreba stare zaprašene hartije... (...) Stao sam slagati listine, čitati i čitati do zlovolje. Kupio sam ovdje, kupio ondje, prebirao zapisnike, račune, učio knjige i stare i nove. Kopao sam da iskopam ruševine staroga Zagreba...“ $(\text { Zlatarovo zlato })^{87}$

Šenoa čitatelja upoznaje s povijesnim vrelima koja je koristio, pri čemu su ti popisi ponekad zaista pozamašni. Tako se u predgovoru Seljačke bune poziva na povijesne zapise Račkoga, Sakcinskoga, Mesića, Krčelića, Habdelića, Ratkaja, ali i na zapise Hrvatskoga

\footnotetext{
${ }^{87}$ Prema Šenoa, August. 2004. Zlatarovo zlato, str. 5. Zagreb: Večernji list.
} 
sabora, kao i na različite sudske izvještaje o parnici između Susjedgrada i Stubice te istrazi protiv Tahija ( Šenoa 1963: 11 - 12).

Milutin Cihlar Nehajev, kao pisac klasičnog ili Šenoinog modela, također u predgovoru svoga povijesnoga romana $V u c i$, detaljno iznosi literaturu koju je morao savladati u pripremnoj fazi, npr. spominje Mesićeve, Klaićeve, Kukuljevićeve, Milčetićeve, Lopašićeve i Horvatove radove (v. Matanović 1998: 155).

Referirajući se na konzultirane dokumente, Šenoa redovito ističe načelo vjerodostojnosti i težnju istini:

„Gledao sam da bude to vjerna prilika onoga vremena. Tko mari uvjeriti se o tom, pročitaj ovoj knjizi i vidjet će da se je sve što evo pripovijedam s veće strane uistinu zbilo..." (Zlatarevo zlato ${ }^{88}$

„Povijesti nisam se iznevjerio, nije mi toga ni trebalo. Sve su osobe u toj knjizi - pa i zadnji sluga - historične, svi užasni prizori, sva zlodjela krvnika su istinita..." (Seljačka buna $)^{89}$

Uzevši u obzir odnos pisca povijesnoga romana prema povijesnoj građi, tj. „komunikaciju“ povijesne građe i književnih postulata, Viktor Žmegač (1994.) ukazuje na dvojakost spomenutoga odnosa:

„u jednom slučaju primat je pripao zakonitostima književnoga djela pa su se povijesne činjenice podvrgavale prilagodbi koju je zahtijevala intencija teksta; $\mathrm{u}$ drugom je pak slučaju mjerilo bila povijesna autentičnost, a te se autentičnosti morao strogo pridržavati i književni ustroj djela“"(74).

Na tragu upravo iznesenoga, Šenoa nije ,zaboravljao“ da u književnome djelu vrijede prvenstveno književna pravila i da povijesna građa ne smije opterećivati samu priču (zato na povijesne izvore upućuje uglavnom u predgovorima ili bilješkama na kraju romana). S druge strane, primjerice, povjesničar i književnik Eugen Kumičić (jedan od nasljednika Šenoine poetike povijesnoga romana), u težnji za potpunom autentičnošću, gomila „sirovu“

\footnotetext{
${ }^{88}$ Vidi prethodnu fusnotu.

${ }^{89}$ Prema Šenoa, August. 1963. Seljačka buna. U: Sabrana djela (knjiga IV.), priredio Slavko Ježić, str. 11. Zagreb: Znanje.
} 
povijesnu građu unutar tkiva same priče, pri čemu njegov stil više nalikuje znanstvenopublicističkome nego književnoumjetničkome (v. Matanović 1998: 83 - 91).

U odnosu na tradicionalni povijesni roman, koji je svoj svijet gradio na pitanju „Kako se postiže povijesna autentičnost?““, suvremeni povijesni romani zaokreću svoj fokus interesa te se pitaju „Što je uopće povijest? Može li se prošlost uopće spoznati i tumačiti?““(Žmegač 1994: 73 - 74).

Iz toga razloga u (post)modernim povijesnim romanima ,nazočnost povijesnih elemenata ne pobuđuje dojam historicističke pedanterije“ (Žmegač 1994: 79); takvi romani, naprotiv, zastupaju radikalno drugačiji odnos prema povijesti, odnosno spoznavanju prošlosti, slijedom čega razvijaju istovremeno opušten i skeptičan odnos prema (povijesnome) dokumentu.

Dok je piscu tradicionalnoga povijesnog romana scottovskog/šenoinskog tipa bilo nezamislivo ,iznevjeriti se povijesti“ (Šenoa), pisci suvremenih povijesnih romana u stranim književnostima kreiraju slike prošlosti koje odstupaju od službenih verzija.

Tako su „tipične strategije postmodernog povijesnog romana: apokrifne povijesti, anakronizmi, povijesna fantastičnost (fantasy)“ (McHale 1987: 90). Koriste se različite vrste falsificiranja povijesnih podataka da bi se istaknula mogućnost mnemoničkih grešaka povijesnih zapisa (Hutcheon 1988: 114).

Posebno su zanimljive apokrifne ili „tajne“ povijesti koje se temelje na ideji paralelnih ili alternativnih povijesti, a svoju kontradiktornost u odnosu na službene povijesne dokumente ostvaruju metodom nadopunjavanja određenog općeprihvaćenog povijesnog zapisa u smislu pronalaska nečega izgubljenoga/zataškanoga ili pak zamjenjivanjem i razmještanjem određenih povijesnih podataka (v. McHale 1987: 90).

Ovakvo poigravanje slikama prošlosti ucijepljenima u službene dokumente zaobišlo je hrvatski (novo)povijesni roman, koji je svoje odmake od tradicionalnoga povijesnog romana ostvario drugačijim strategijama. Između ostaloga, ,alegorijska i parabolična razina oslobađa te romane puke povijesne dokumentaristike i rekonstrukcije, pa se zbog toga i razlikuju od šenoinskog tipa romana“ (Milanja 1994: 1093).

Osim toga, što se tiče odnosa suvremenoga hrvatskog povijesnog romana prema dokumentu, važno je uočiti i element (ne)pouzdanosti. Tako, primjerice, pripovjedači Nedjeljka Fabrija ili Ivice Ivanca znaju iskazivati nesigurnost, ali i potpunu opuštenost prilikom iznošenja vremenskih kategorija (vrijeme zbivanja, kronološka dob protagonista i s1.). ${ }^{90}$

\footnotetext{
90 „U ljeto te ili svejedno koje od tih godina“ (Fabrio 2005: 95)

„Sjedi Carlo (...) A već mu je sedamdeset i treća. Ili četvrta?“ (Fabrio 2005: 150)

„Hiljadu osamsto dvadeset i pete? Ne? Da, pa da. 1825. godine.“(Ivanac 1990: 9)
} 
Dok je Šenoin pripovjedač u čitatelju stvarao dojam kako je priča pred njim nastala na osnovi obimnih i provjerenih podataka, u suvremenome hrvatskom povijesnom romanu zna se pripomenuti kako o nečemu baš i ,nema preciznih podataka“991.

Ponekad se čak eksplicitno upućuje na nemogućnost (re)konstrukcije cjelovite povijesne „,istine“ putem povijesnih dokumenata, kao što to čini Ivan Katušić u svome romanu Admiralski stijeg: Maksimilijanove bilješke o istrazi protiv Vicka Viribusa na kraju romana prekidaju se bez nekakvog zaokruženoga završnog dijela. Tako je roman sveden na zbir subjektivnih istina svjedoka u sudskom procesu, bez mogućnosti proizvodnje objektivne istine o događajima; povijesna istina ostaje nedorečena, a samim tim i nedokučiva.

Pisci (post)modernih povijesnih romana pokazuju višu razinu (samo)svijesti prilikom uporabe historiografskoga sloja, budući da taj sloj nije tek „čista povijest““ nego uvijek „preparirani diskurs“, tj. ,ispripovijedana povijest“ (v. Milanja 1994: 1097).

Linda Hutcheon u svome radu o historiografskoj metafikciji (v. 1988: 122 - 123) upućuje na svjesnost postmodernističkih djela o razlici između događaja (koji sami po sebi ne posjeduju značenje) i činjenica (kojima je značenje dano).

U povijesnim romanima, kao i u povijesti, tako je uvijek riječ o nekakvoj kreaciji, proizvodnji činjenica, odnosno proizvodnji značenja na temelju određenih tekstualnih tragova prošlosti (npr. u arhivima).

Tragom upravo navedenoga, suvremeni povijesni romani, u odnosu na tradicionalne povijesne romane, ne inzistiraju na opreci istine i laži (Hutcheon 1988: 109), stoga toliko „ne povezuju istinu sa zahtjevima empirijske provjerljivosti“; puno je važnije ,čija je istina kazana“ (Hutcheon 1988: 123).

Uobičajena korelacija između (povijesnoga) dokumenta i istine ${ }^{92}$ na ovaj je način postavljena kao problematična, a samim time otvorena za uvijek nova propitivanja.

„U isto vrijeme kada je historiografski koncept događaja doživio izgon iz tradicionalno poimane događajne povijesti, upitan je postao i status dokumenta kao egzemplarnog teksta koji se referira na zbilju. (...) Nova je povijest u pitanje dovela samu ideju vjerodostojnosti. Nema prirodnog izraza zbilje, slijepljenog za nju. Autentičnost je pojam podložan interpretaciji.“ (Zlatar 1998: 125)

\footnotetext{
91 „Nema preciznih podataka o tome kakva je bila uloga Vebera Vilmosa, kako se to mađarski pisalo.“ (Bauer 2001: 21)

${ }^{9}$ Usp. npr. Šenoin odnos prema dokumentu i istini.
} 
Dok je u klasičnome povijesnom romanu koncept dokumenta uglavnom bio vezan za važne i velike službene zapise, redovito smještene u gotovo svetim prostorima starih arhiva i knjižnica, „veliki arhivski dokumenti u novopovijesnom se romanu i ne spominju, a i sam pojam dokumenta postaje vrlo rastezljiv“ (Matanović 2003: 130).

Dokument više nije toliko suhoparan zapis ozbiljnog historiografa ili tekst pravnoga karaktera; dokument se sada kao pojam širi na privatna pisma, dnevnike, novinske članke, recepte, fotografije, poetske tekstove, usmeni iskaz...(v. Matanović 2003: 130, 148; Nemec 2003: 286).

Julijana Matanović upućuje na tri načina kojima se dokument predstavlja u novopovijesnoj varijanti hrvatskoga povijesnog romana - u obliku paracitata, slaboga dokumenta ili jakoga dokumenta s intervencijom pripovjedača/autora (2003: 130 - 138). Kao paracitat dokument može simulirati predgovorne bilješke (Feđa Šehović, Gorak okus $d u s ̌ e)$ ili biti inkorporiran u sam tekst (Stjepan Tomaš, Zlatousti).

U romanima Nedjeljka Fabrija (Vježbanje života, Berenikina kosa) zastupljeni su tzv. slabi dokumenti najčešće u vidu novinskoga tiska (npr. članci u Slavenskom jugu), koji su inkorporirani u samo tkivo romana.

U slučaju da se novopovijesni romani pozivaju na jake dokumente, često je uključena intervencija pripovjedača/autora u takve dokumente (Strossmayerov curriculum vitae $i$ kronološki pregled važnijih događaja u Europi od 1848. do 1905. godine u romanu Stjepana Tomaša Zlatousti).

Naredna će potpoglavlja ovoga dijela rada ukazati na kategorizaciju dokumenata u povijesnim romanima Feđe Šehovića, strategije njihove inkorporacije te intertekstualne odnose. 


\subsection{Motiv pronađenoga i sačuvanoga zapisa}

Još se Cervantesov Don Quijote (1605. - 1615.) kao „prvi roman izuzetne vrijednosti u europskoj književnosti““ (Solar 1976: 167) temeljio na konvenciji pronađenoga zapisa: riječ je o rukopisu nekog arapskog povjesničara na koji je našao ,autor““

Tako je povijest romana, na stanovit način, započela upravo s konvencijom pronađenoga rukopisa. Ova je konvencija obilježila kako mnoge romane iz stranih književnosti, tako i one iz hrvatske književnosti.

Čemu služi motiv pronađenoga rukopisa? „Zašto piscu treba drugi pisac i njegov tekst?“ - pita se Gordana Slabinac u svome eseju „Diskurzivne mogućnosti pronađenog rukopisa“ (2006: 38 - 60), uzimajući kao bazu za buduću sintezu odgovora četiri romana iz svjetske književnosti: Don Quijote, bistri vitez od Manche (1605. - 1615.) Miguela de Cervantesa Saavedre, Pierre Menard, pisac Don Quijotea (1939.) Jorgea Luisa Borgesa, Zapisi iz mrtvog doma (1861.) Fjodora Mihajloviča Dostojevskoga i Ime ruže (1980.) Umberta Eca.

Autorica zaključuje kako je Cervantesu pronađeni rukopis poslužio za problematiziranje prezentacije zbilje putem fikcije (tzv. fikcionalna istina); Borges uvodi motiv mogućnosti ponovnoga pisanja iste knjige te time upućuje na prirodu samoga čitanja - čitanjem se uvijek „piše“ novi tekst; Dostojevski pred čitatelja stavlja zapise svjedoka da bi se što autentičnije prikazala robijaška stvarnost (pogled iznutra); Eco, pak, pronađenim zapisom ironijski promišlja cjelokupnu književnu tradiciju.

I pisci hrvatskih suvremenih povijesnih romana nerijetko su posezali upravo za spomenutom konvencijom, najčešće preko motiva urednika koji je pronašao/spasio određene spise te ih objavio, uz određene uredničke pripreme, napomene, intervencije i sl. U humorističkome povijesnome romanu Magarcima pucaju rebra (1980.) Leo Držić kreira „Zapise varoškoga skribe Dominika Pivarića“, zagrebačkoga pisara koji je početkom 17. st. bilježio gradsku kroniku.

Ivan Katušić u Admiralskome stijegu (1987.) uvodi pripovjedača koji se poziva na rukopise o istrazi protiv Vicka Viribusa, optuženoga za sudjelovanje u potapanju admiralskoga broda $u$ Puli odmah nakon propasti Austro-Ugarske (1.11. 1918.). 
U Kratkoj kronici porodice Weber (1990.) Ludwig Bauer autorskom pripovjedaču predaje u ruke zapise učiteljice Gizele, pripadnice porodice Weber (koja je živjela u Gradecu sto dvadeset godina, od sredine 19. st. do druge polovice 20. st.).

Kao motiv pronađenoga rukopisa Stjepanu Tomašu poslužio je u romanu Zlatousti (1993.) privatni dnevnik velike povijesne ličnosti - biskupa Josipa Jurja Strossmayera.

Feđa Šehović konvenciju pronađenoga rukopisa koristi u svim romanima svoje novopovijesne trilogije (Gorak okus duše, Oslobađanje đavola, Uvod u tvrđavu).

Autorski se pripovjedač u predgovornim bilješkama romana Gorak okus duše poziva na rukopis fra Mavra S. (iz 1620. godine) poprilično duga naslova, s obzirom da su u naslovu navedene najvažnije odrednice sadržaja samoga rukopisa:

\author{
KRONIKA O PORIJEKLU I IMENU SELA BEZBOZI TE O SUDBINI FRA \\ VINCENCA I NJEGOVA NEPUTA VICKA KOJI PRVI NASELI BRIJEG POVIŠE \\ MORA, A ČIJI UNUK U KASNIJIM GODINAMA SVOJIM PREDA MI \\ DRAGOCJENE SPISE KOJI MI POSLUŽIŠE ZA SAČINIT OVO DJELO NA \\ JEZIKU DOMAĆEM. ANNO CHRISTIANAE M D C L. (GOD: 9)
}

Važan segment spomenutoga pronađenog rukopisa predstavlja Vickova mala pjesnička zbirka (25 pjesama), koja je pridodana kao deveto poglavlje romana Gorak okus duše (146 - 156).

Naslov romana Oslobađanje đavola istoimen je naslovu inkriminirane poeme dubrovačkoga pjesnika i filozofa fra Mavra Sarake, percipirane kao „najgnusniji antidržavni politički pamflet“"(OĐ: 35). Sam tekst poeme nije prisutan, odnosno na njezin sadržaj, kao i na recepciju, pripovjedač se samo poziva tijekom fabularnoga izlaganja. Status pronađenoga zapisa u Oslobađanju đavola posjeduje rukopis suca Andrije Menčetića „DE INFERNIS ANNOTATIONES (Zapisi o paklu)“, u kojem su izneseni događaji vezani uz veliki dubrovački potres 6 . travnja 1667. godine.

Na rukopis se upućuje tijekom samog pripovjednog izlaganja i u fusnoti, a neki su od dijelova rukopisa inkorporirani u tekst romana.

Dio Andrinog rukopisa predstavljaju različita pisma i izvještaji svjedoka potresa, umetnuta u posljednji dio romana. 
Kako je već spomenuto u početnim dijelovima ovoga rada, roman Uvod u tvrđavu, posljednji dio Šehovićeve novopovijesne trilogije, u cijelosti funkcionira kao obiman i diskurzivno šarolik zbir dokumenata.

Čine ga testimonijalni zapisi Luke i Pepa, dvojice prijatelja koji dijele užase logorskih iskustava, govori svjedoka koji ukazuju na osobitosti Pepova i Lukina djetinjstva i mladenačkih dana, Lukina pisma i dnevnički zapisi te Pepove pjesničke poslanice. U užem smislu, motiv pronađenoga rukopisa odnosi se na ,paket“ Pepovih zapisa koji završavaju u Lukovim rukama nakon Pepove smrti, a o čemu Luko epistolarno izvještava brata Nikšu.

Svim rukopisima u Šehovićevim romanima zajedničko je (kao jedno od stalnih mjesta konvencije pronađenoga zapisa) pripovjedačevo iznošenje informacija vezanih uz njihov sadržaj, opseg, kompoziciju, tip slova i sl., a sve u cilju izgradnje efekta uvjerljivosti i autentičnosti. U tome kontekstu mogu se usporediti sljedeći odlomci iz Šehovićevih romana $^{93}$ :

„Rukopis Kronike sastoji se od 178 listova kvarto formata, s malim oštećenjima na listovima 32, 85, 90 i 161 kasnije paginacije. Zapravo samo prvih 58 listova pripada Mavrovoj Kronici i oni su uredno označeni arapskim brojevima. Na slijedećih 97 listova tri puta su različitim rukopisom upisivane stranice. To su spisi napisani istim rukopisom na hrvatskom i latinskom jeziku, gdje se pored opširnijih Vickovih zapisa o svom životu i doživljajima svoga ujaka fra Vincenca, nalaze i rasprave iz oblasti poezije, filozofije i etike. Preostali listovi sačinjavaju malu zbirku Vickovih pjesama

\footnotetext{
${ }^{93}$ I u gore spomenutim novopovijesnim romanima drugih književnika, koji koriste konvenciju pronađenoga zapisa, navode se karakteristike tih zapisa. Usp. primjerice:

„Ostatak one hrpe bile su neke pljesnive knjige i spisi (među njima bio je rukopis varoškog skribe Dominika Pivarića)(...) Sredio sam požutjele listove rukopisa. Nije nedostajalo ništa, osim nekoliko prvih stranica." (Držić 1994: 12 - 13)

„snop požutjelog papira različitih formata bio je dobro stegnut između tvrdih kartonskih korica“ (Katušić 1987: 9)

„Radi se o povelikoj gomili papira, dokumenata, pisama, fotografija, bilješki, nekoliko dnevnika, književnih radova i fragmenata i - na prvom mjestu - o nesređenoj i nepotpunoj, iako nadasve opširnoj porodičnoj kronici; vrijednom, ali nedovršenom pokušaju, ispisanom Gizelinom rukom u tri bilježnice tvrdih korica." (Bauer 2001: 7)

„hrpa listina ispisanih sitnim Strossmayerovim rukopisom“ (Tomaš 1993: 60)
} 
koje su osobito oduševile fra Mavra, o čemu jasno svjedoče njegovi kratki komentari na marginama listova.“(GOD: 9 - 10)

„Pozamašni rukopis „DE INFERNIS ANNOTATONES“ (Zapisi o paklu) podijeljen je u tri poglavlja: 1. 'Događaji prije i poslije trešnje', 2. 'O Božjoj kazni i milosrđu', 3. 'Dijalozi s okrivljenim pjesnikom'. Dok su u prvom dijelu suho i racionalno ispričani događaji šest mjeseci prije i šest mjeseci poslije trešnje, $u$ drugom i trećem dijelu sudac Andro ugodno iznenađuje čitatelja hrabrom i lijepo izrečenom mišlju. (...) U trećem dijelu naslovljenom s 'Unde mallum?', osim učenih, ali dugih i zamornih dijaloga o đavlu i zlu, ističu se dijalozi o slobodi uopće i posebno o slobodi umjetnika, ispisani vrlo bogatim i umnim latinskim jezikom.“(OĐ: 169)

„Teta Perica je otišla nekud iz saloče da mi donese 'paket' Pepovih rukopisa. (...) U tom naizgled malom paketu ima oko pet stotina stranica gusto pisanog teksta (što rukom, što na stroju). Osim 'Biblije', čiji je sada glavni naslov 'Tvrđava', ima tu razne rukopisne građe: esejističkih zapisa, pjesama i poslanica, pokušaja pisanja dnevnika i raznih bilježaka. Dobro poznajem sitni Pepov rukopis...“(UUT: 193 - 194)

Govoreći o konvenciji pronađenoga zapisa, važno je u nekim primjerima uočiti još jedno stalno mjesto te konvencije - emfatična reakcija pronalazača rukopisa, koja proizlazi iz značajnosti samoga čina pronalaska nečega što je moglo ostati izgubljeno za povijesni uvid:

„Shvatio sam da u rukama imam bogatstvo i najednom sam se počeo ponašati poput Držićeva Skupa.“(UUT: 194) ${ }^{94}$

\footnotetext{
${ }^{94}$ Usp.

U Tomaševu romanu Zlatousti novinar koji je došao u Osijek i Đakovo na simpozij o Strossmayeru ovako reagira pred škrinjom rukopisa koju mu je u tajnosti i diskreciji predao svećenik Rufin:

„Ostavio me samog kao crkvenog miša pred bezbrojnim kolutovima sira, kao razbojnika u Ali-babinoj pećini.“ (Tomaš 1993: 52)

Iako se ne radi o žanru (novo)povijesnoga romana, u ovome kontekstu nezaobilazno je spomenuti ushićenje pronalazača rukopisa u možda najpoznatijoj primjeni konvencije pronađenoga zapisa u novijoj hrvatskoj književnosti - Koraljnim vratima (1990.) Pavla Pavličića.

Protagonist romana - jednooki filolog Krsto Brodnjak - ovako (između ostaloga) reagira na otkriće izgubljenih pjevanja (14. i 15.) Gundulićeva Osmana:

„Papir mu je drhtao u ruci, u ritmu srca. Počeo je čitati glasno, jer je morao biti siguran. Glas mu je drhtao i čudno odjekivao u toj praznoj prostoriji (...) kao da to govori rukopis, povijest sama. (...) Polako je odložio rukopis na pod kraj sebe, i zabacio glavu. Nastojao je ovladati vlastitim mislima, koje su bile hladne, trezvene i nezainteresirane za sve na svijetu osim za rukopis, ali raspršene i zabavljene raznim licima toga otkrića. Što je sve to skupa moglo značiti? (...) Je li moguće da se ostvario njegov san, i to baš onako kako ga je sanjao, budan i
} 
Svi navedeni primjeri pronađenih rukopisa u Šehovićevim romanima temelje se na poziciji svjedoka pojedinih događaja. Kronika fra Mavra S. (Gorak okus duše) uglavnom zahvaća „pogled i riječi“ don Vicka kao svjedoka svoje i ujakove „muke“; Zapisi o paklu (Oslobađanje đavola) odnose se na zapise suca Andrije, svjedoka velikoga potresa koji je zahvatio grad Dubrovnik 6. travnja 1667. godine; pronađeni zapisi u Uvodu u tvrđavu reflektiraju (uglavnom) logorska iskustva dvojice prijatelja Pepa i Luke u vremenima totalitarnih režima 20. stoljeća.

Dok je osamdesetih godina 20. stoljeća u romanima dubrovačke trilogije dosljedno koristio konvenciju pronađenoga rukopisa, Feđa Šehović u romanima nastalima u 21. stoljeću (petoknjižje Ilijasbegovići, Prokleta ergela) više se fokusirao na motiv sačuvanoga zapisa nego pronađenoga.

Iako se može učiniti da je u slučaju pronađenih i sačuvanih zapisa riječ o nekim raznorodnim pojavama, zapravo se radi o srodnim, čak i komplementarnim motivima, o dvjema stranama iste pojave. Naime, nešto se mora sačuvati u pismu da bi bilo pronađeno za potencijalnoga čitatelja. Na ovaj način Šehović je cjelovito zahvatio motiv zapisa, i s aspekta zapisivanja i s s aspekta zapisanoga kao produkta procesa pisanja.

Narativni ustroj Proklete egele temelji na zapisima što su ih nasljednici s visokom razinom samosvijesti ostvarivali u sjećanje na svoje prethodnike/uzore.

Pripovjedač podatke o protagonistima ovoga romana donosi upravo upućivanjem na pisane tragove o njima: o fra Iliji (protagonist prvoga dijela romana) doznaje se preko zapisa njegova nasljednika fra Andrije $O$ životu $i$ djelu fra Ilije, 1648., dok se fra Andrijin život i djelovanje uglavnom (re)konstruira preko zapisa mladoga fra Marka Anđelovića Život i djelo pravednika fra Andrije A. i njegova uzora fra Ilije K., 1689. te u rukopisu O svom učitelju i uzoru fra Andriji mučeniku.

Gradeći priču na motivu sačuvanih zapisa, pripovjedač će iznijeti svoje komentare o važnosti zapisivanja, o pisanoj riječi kao jedinom sigurnom i trajnom mjestu pohranjivanja nečijeg ,života i djela“:

„Ne bi se ništa znalo o fra Andrijinih posljednjih deset godina života u planinskoj kolibi, da o tom nije ostavljen duži i znalački sročen zapis.“ (PE: 166)

spavajući, zdrav i bolestan, pijan i trijezan, u svako doba, san da nađe cjelovitoga Osmana?“ (Pavličić 2004: 32 33) 
„Da ne bi fra Marka, malo ili šturo bi se znalo o fra Andriji, a poglavito o posljednjim godinama njegova života.“ (PE: 167)

Imperativom zapisivanja obilježeni su i Šehovićevi Ilijasbegovići. Životi i djela protagonista pojedinih romana ovoga ciklusa oblikovani su posredstvom zapisa njihovih nasljednika i/ili bližnjih.

U ovome su kontekstu reprezentativni početni i završni dio Ilijasbegovića budući da demonstriraju situaciju zapisivanja riječi primarnoga svjedoka, odnosno proizvodnju pozicije sekundarnoga svjedoka upravo preko uloge zapisivača i prenošenja tuđe riječi/sudbine.

O životu i djelu trebinjskoga bega iz 17. stoljeća Ilijas-bega stvorit će pozamašan zapis njegov prijatelj i istomišljenik fra Matija Kopčić, između ostaloga i metodom „govorenja u pero“:

„I on mi tada reče: 'Piši Matija, piši. Ja, Ilijas-beg Ilijasbegović..."“ (I: 7, istaknula D. M. L.)

Ilijasbegovići završavaju istovjetnom situacijom smještenom preko 300 godina poslije: Enko kao najmlađi izdanak obitelji Ilijabegović, boraveći u haškome zatvoru nakon posljednjega rata u Bosni i Hercegovini,

„'govori u pero' kome drugom nego nekom fra Petru: 'Piši, fra Petre, piši! Uoči prve godine trećeg tisućljeća, ja Enver-beg Ilijasbegović..."“ (I: 1002, istaknula D. M. L.)

Upravo motiv zapisivanja riječi svjedoka predstavlja element koji spaja početak i kraj ciklusa o Ilijasbegovićima, tvoreći tako svojevrsnu uokvirenu kompoziciju.

Isti zahtjev svjedoka odjekuje stoljećima: riječ je o imperativu „(za)piši“, u kontekstu apela sugovorniku koji će čuti nečije svjedočenje i dalje ga prenositi, stvarajući lanac svjedočenja. Za Ilijasbegoviće bi (ali i ostale Šehovićeve romane) stoga kao motto mogao funkcionirati naslov povijesnoga romana bosanskog književnika Jasmina Imamovića Molim te, zapiši (2009.) ili riječi Andrićeva fra Petra „Zapiši, pa će i bog upamtiti!““(v. Lovrenović 2005: $337)$.

Govoreći o suodnosu uokvirene kompozicije i imperativa zapisivanja, zanimljivo je podsjetiti na jednu od kompozicijskih osobitosti Proklete avlije (1954.) Ive Andrića. Početak i kraj Proklete avlije vezani su uz prizor popisivanja onoga što je ostalo iza pokojnoga fra Petra. Fra Mijo Josić „,govori u pero“ mladome fra Rastislavu popis fra Petrova 
alata, uz zahtjev ,piši““, pri čemu je na stilskoj razini zamjetljiv paralelizam izraza, usporediv s gore navedenim citatima iz Šehovićevih Ilijasbegovića:

„Piši dalje - čuje se opori glas starog fratra - piši: Jedna kliješta velika, kreševska. Jedna.“ (Andrić 2014: 6, istaknula D. M. L.)

„Dalje! Piši: jedna testera od čelika, mala, njemačka. Jedna!““ (Andrić 2014: 80, istaknula D. M. L.)

Iako u određenome kontekstu popisivanje nečija alata može djelovati čak i apsurdno, i ovaj primjer ukazuje na zahtjev za svojevrsnom arhivizacijom onoga što ostaje od ljudske sudbine, zahtjev za stvaranjem određenih tragova prošlosti koji će u nekim drugim vremenima uvijek iznova omogućiti „domišljanje (te) prošlosti“‘95.

Što se tiče tragova prošlosti, Feđa Šehović u svim svojim povijesnim romanima postavlja motiv zapisa (pronađenoga i/ili sačuvanoga) kao uporište bilo kakvoga promišljanja o toj prošlosti, čime se naslanja na postavke Linde Hutcheon o nužno tekstualiziranoj dostupnosti prošlosti:

„Kako danas spoznajemo prošlost? Preko njezinih diskursa, njezinih tekstova odnosno, kroz tragove povijesnih zbivanja: arhivske materijale, dokumente, priče svjedoka...i povjesničara.“ (Hutcheon u Biti 2002: 37)

Iako se na određenim mjestima koristi i usmenim iskazom, Šehović prvenstveno pisanu riječ vidi kao osobito mjesto pohrane priča o sudbinama pojedinaca na pozornici povijesnih mijena. U duhu latinske poslovice koja poručuje da riječi lete, a zapis ostaje. ${ }^{96}$ Pri tome Šehović zapise najčešće konstruira kao prostore za iskaze svjedoka, koji pak progovaraju svojim vlastitim iskustvom ili prenoseći tuđe iskustvo.

\footnotetext{
${ }^{95}$ Izraz Nenada Ivića. Vidi: Ivić, Nenad. 1992. Domišljanje prošlosti: Kako je trinaestostoljetni arhiđakon Toma napravio svoju salonitansku historiju. Zagreb: Zavod za znanost o književnosti. ${ }^{96}$ Verba volant, scripta manent (lat.).
} 


\subsection{Diskurzivna klasifikacija dokumenata}

\subsubsection{Kronike}

Dovodeći u vezu naraciju i reprezentaciju zbilje, američki povjesničar i teoretičar Hayden White (v. 1987: 1 - 25) uočava tri načina historijske (re)prezentacije: anale, kroniku i historiju.

U analima izostaje narativna komponenta, događaji se tek kronološki nižu jedan za drugim; nema subjekta, a time ni njegova odnosa prema događajima.

Za razliku od pisca anala, kroničar u određenoj mjeri ostvaruje odnos prema onome o čemu piše, dolazi do svojevrsne identifikacije. Prisutno je pripovijedanje, prošlost se izlaže kao neka vrsta priče, ali priča bez završetka, zaključka - nedovršena priča.

Tako, prema Whiteu, analima i kronikama nedostaje ,značenje“ lanca događaja (16).

S druge strane, historija kao modus prezentacije prošlosti posjeduje završenost i zaokruženost događaja, a time i element vrednovanja, odnosno moralnu obojenost.

Vladimir Biti (2000a) smatra spornom Whiteovu tvrdnju da „u ljetopisu i kronici događaji 'govore sebe' dok im se u priči pridomeće iskrivljujući 'višak značenja'; značenjski je višak (u različitoj mjeri) imanentan svim formama historiografijskog iskazivanja jer je bez njega nemoguće postići dojam zbiljnosti događaja“"(404).

Što se tiče terminologije, Andrea Zlatar oslanja se na Whiteove kategorije, ali upotrebljava pojam anala kao sinonim ljetopisima, a historiju povijesti, pri čemu naznačava kako su ljetopisi najjednostavnija, a povijest najsloženija forma historiografskih oblika, među kojima se smjestila kronika (v. 1998: 23, 71).

Proučavajući ljetopise bosanskih franjevaca iz 18. stoljeća ${ }^{97}$, Iva Beljan (2011.) ne govori o ljetopisima kao istoznačnici analima, već anale promatra kao jedan od žanrova unutar ljetopisa kao polidiskurzivnog zbornika.

Iste se terminološke nejasnoće mogu zamijetiti i pri uporabi već ustaljene sintagme „franjevačke kronike“. Naime, prema Ivi Beljan, franjevački ljetopisi žanrovski su raznovrsni zbornici na razmeđu historiografije i književnosti, čije sastavnice predstavljaju kako već spomenuti historiografski ,žanrovi“ (anali, kronike i historije/povijesti), tako i oni više

\footnotetext{
${ }^{97}$ Ljetopis Nikole Lašvanina, Ljetopis sutješkoga samostana Bone Benića i Ljetopis kreševskoga samostana Marijana Bogdanovića
} 
književni (propovijedi, hagiografije, pjesme, usmena predaja, putopisi, poslovice i izreke, natpisi u kamenu...) (v. 37 - 95).

Franjevački ljetopisi (uobičajeno u književnoznanstvenoj literaturi zamjenjivani bliskoznačnicom, ali ne i istoznačnicom „franjevačke kronike“) izvršili su znatan utjecaj na pripovjedače, posebice na Ivu Andrića.

Još je u Andrićevoj doktorskoj disertaciji ${ }^{98}$ značajno mjesto zauzimalo „kulturno i literarno djelovanje bosanskih franjevaca“" (Nemec 2016: 221), a upravo su franjevačke kronike predstavljale bogato vrelo motiva na kojima je izraslo Andrićevo književno djelo.

U tome kontekstu posebno mjesto zauzimaju franjevačke kronike, tj. ljetopisi iz 18. stoljeća Ljetopis fra Marijana Bogdanovića i Ljetopis fra Nikole Lašvanina (Nemec: 2016: 223). Andrićev književni imaginarij donio je upečatljive likove bosanskih franjevaca, kako u nizu tzv. „franjevačkih pripovjedaka“" 99 , tako i u romanesknome opusu.

Osim tematsko-motivski, na razini priče, franjevačke su kronike utjecale i na diskurzivni aspekt, dakle sam način oblikovanja priče, što je katkad istaknuto i u naslovu djela.

Tako Andrićev roman Travnička hronika već naslovom sugerira oponašanje diskursa i Žanrovskih konvencija franjevačkih kronika (Nemec 2016: 223), a roman Na Drini ćuprija u ranijim je izdanjima nosio podnaslov Višegradska hronika (Lovrenović 2005: 319). „Upravo kroničarski prosede i model leži u temelju mnogih drugih Andrićevih proza.“ (Lovrenović 2005: 319)

Ipak, „tema bosanskog franciskanizma u književnosti nije rezervirana samo za Ivu Andrića (premda je o „Andrićevim franjevcima“ u književnoj kritici ponajviše pisano)“ (Begović-Sokolija 2017: 60). Tako se utjecaj franjevačkih kronika može zamijetiti u suvremenih hrvatskih i bosanskih pisaca, primjerice u opusu Ivana Aralice (v. Nemec 2003: 272), Ivana Lovrenovića, Dževada Karahasana, Irfana Horozovića (v. Begović-Sokolija 2017: 62 - 70), Miljenka Jergovića (Beljan 2011: 99)...

Spomenutom nizu književnika, koji predstavljaju „franjevačku pripovjedačku Bosnu“ (Begović-Sokolija 2017: 61), nužno je priključiti hrvatskoga, ali i bosanskoga/bošnjačkoga književnika Feđu Šehovića.

\footnotetext{
${ }^{98}$ Razvoj duhovnog života u Bosni pod utjecajem turske vladavine, 1924. (v. Nemec 2016: 220)

${ }^{99}$ Vidi: Vaglio, Luca. 2015. „Andrićev ciklus o fra Petru“. U: Ivo Andrić - svugdašnji (Zbornik radova s Međunarodnoga znanstvenog skupa održana 25. studenoga 2005. u Zagrebu), 69 - 84. Zagreb: Hrvatsko kulturno društvo Napredak.
} 
U Šehovićevim romanima Gorak okus duše, Ilijasbegovići: Cronica travuniana te Prokleta ergela značajno mjesto zauzimaju upravo franjevačke kronike/ljetopisi kao dokumentarni oslonac priči.

Autorski pripovjedač (potpisan kao Autor) u predgovoru Gorkoga okusa duše upućuje čitatelja da će se roman temeljiti na Kronici (1620. g.) fra Mavra S. (vjerojatno Sorkočevića), učenoga fratra koji se iz nekih razloga zamjerio Dubrovačkoj Republici, zbog čega je protjeran u pusti zaselak prozvan Bezbozi. Upravo će ova onomastička posebnost predstavljati fra Mavru poticaj za pisanje Kronike.

Svojim sadržajem fra Mavrova kronika zapravo predstavlja tipičan franjevački ljetopis u kontekstu definicije već spomenute Ive Beljan. Naime, za početak, Kroniku obilježava diskurzivna raznolikost kao i poliautorska obilježenost njezinih sastavnica. Uz kroničarske dijelove, čiji je autor fra Mavro, navodi se kako Kronika o porijeklu i imenu sela Bezbozi te o sudbini fra Vincenca i njegova neputa Vicka... sadrži različite zapise dum Vicka: biografske zapise o ujaku Vincencu, rasprave o poetskim pitanjima, filozofiji i etici te Vickove pjesme.

Ljetopis nije tek „kronološki organizirano izvješće o prošlosti“, već „,zbornik što okuplja različite dijelove velike priče o nastanku, prijetnji i opstanku povijesnoga subjekta“ (Beljan 2011: 230). Ljetopisi su, dakle uvijek upućeni na zajednicu u kojoj nastaju i vezani su za interese te zajednice. Tako autorski pripovjedač podsjeća u Predgovoru Gorkoga okusa duše na zapise vitaljskih župnika, između ostaloga i fra Mavrov,

„koji svjedoče o upornom nastojanju duhovnih pastira da sve nejasnoće prolaznoga svijeta objasne svom neukom stadu, pa i podrijetlo imena Bezbozi“ (GOD: 9).

Važno je zamijetiti odmak od uobičajene svrhe ljetopisa za recipijenta budući da interes autora/pripovjedača ne predstavlja zajednica; povijesni subjekt za njega je pojedinac i njegova vlastita ,muka“ :

„Na osnovu spomenute rukopisne građe odlučih se napisati roman o sudbini fra Vincenca i njegova neputa Vicka, uvjeren da njihova muka ne pripada samo davnom šesnaestom stoljeću..." (GOD: 10) 
I ostali franjevački zapisi u spomenutim Šehovićevim romanima pokazuju svojstvo usredotočenosti na pojedinca, što je često iskazano i samim njihovim naslovom, u kojem se upućuje na nečiji život i djelo.

Tako je fra Andrija (Prokleta ergela) autor zapisa $O$ životu i djelu uzora fra Ilije (1648.), fra Marko Anđelović (Prokleta ergela) piše Život i djelo pravednika fra Andrije i njegova uzora fra Ilije K. (1689.) te O svom učitelju i uzoru fra Andriji mučeniku, a fra Matija Kopčić (Ilijasbegovići: Ilijas-beg, kapetan trebinjski) donosi Ilijas-begov život u djelu De - Ilias-beg vitae et rebus commentarius, 1696.

Iako naslovljava djelo Prisjećanja sa Soče i Piave, čime se upućuje na kronološko zahvaćanje velikih povijesnih zbivanja (bojišta Prvoga svjetskog rata), fra Ivan Lovrenović (Ilijasbegovići: Begovina) fokusiran je na sudbinu svoga prijatelja Ilijas-bega te se postavlja u poziciju „svjedoka Ilijas-begove golgote“ (I: 417). U istu je poziciju postavljen i fra Petar prema ,žrtvenome jarcu“ Enku u završnim poglavljima Ilijasbegovića (Od Mostara do Den Haaga).

Vidljivo je, već i po samim naslovima, da franjevački zapisi u Šehovićevim romanima funkcioniraju prvenstveno kao biografski zapisi, čime ostvaruju zaokret od očekivanoga plana povijesnih zbivanja na pojedinačne sudbine onih koji su zahvaćeni tim zbivanjima. Specifičnost franjevačkih ljetopisa i leži u odmaku od općih povijesnih zbivanja na zbivanja koja određuju život neke zajednice, primjerice nekog franjevačkoga samostana:

„Obzor historije zamijenjen je živom panoramom ubogog konkretnog života“ (Lovrenović 2005: 338), stoga franjevački kroničari bilježe „historiju svakodnevnice““ (isto: 339).

U odnosu prema službenoj varijanti povijesti, franjevačke kronike pokazuju određeno svojstvo subverzivnosti budući da funkcioniraju kao

„dokumentarni arhivi male povijesti, bilježenje poslova $i$ dana, neka vrsta tekstualnih muzeja u kojima je pohranjeno kulturno pamćenje alternativno u odnosu na vladajuće historiografske diskurse“ (Kazaz 2015: 52).

Upravo spomenuto svojstvo franjevačkih kronika dolazi do izražaja u Šehovićevim povijesnim romanima, s tim da je Šehović polje interesa dodatno suzio na život pojedinca, čime se kronikalnost udružuju s biografijom tvoreći „kronikalnobiografski model“ (Zlatar 2000: 110). 
„Kronika unutar svoje tematske zaokupljenosti jednim gradom, dvorom, opatijom i slično, zacrtava životopisne modele; uz to, ona može u potpunosti poslužiti kao model biografiji: životopis sagledan kao res gestae pojedinca.“ (isto: 143)

Franjevci kao autori biografskih zapisa u Šehovićevim romanima (fra Andrija, fra Marko, fra Matija, fra Ivan, fra Petar) svoj legitimitet na priču o drugome ostvaruju položajem svjedoka. Vjerodostojnost takvoga iskazivanja temelji se na svjedočanstvu tipa „ono što sam vlastitim očima vidio“ i ,što mi je izravno pripovijedao onaj koji je sudjelovao“, a što svoju tradiciju vuče još iz antičke historiografije (Zlatar 2000: 111). Iznoseći priču o životu drugoga, zapisivači u narativ upliću i segmente vlastitih priča, odnosno „biografija se kao pripovijest o tuđemu životu, a iz perspektive govornog subjekta razvija i kao njegova autobiografija. (...) Na djelu je, zapravo, uvijek (auto)biografija.“ (Velčić 1991: 41) Stoga se „načelno razlikovanje autobiografije, kao pisanja o sebi i biografije, kao pisanja o drugome, urušava....“ (Zlatar 2000: 155).

Unutar ovakvoga konteksta može se reći da Šehovićevi likovi-zapisivači postaju dvostruki svjedoci: nastupaju i kao sekundarni svjedoci (pišu o onome što se drugima dogodilo, a što nije i njihovo vlastito iskustvo), ali i kao primarni svjedoci (iznošenje onoga što su sami iskusili). $^{100}$

Spomenuti kronikalnobiografski zapisi u Šehovićevim romanima već svojim naslovima upućuju na tzv. vitae i gestae (život i djelo) kao žanrove srednjovjekovne historiografske proze. Za razliku od gestae - u kojima se izvještava o djelima osoba koje su se izmjenjivale na nekim položajima (Beljan 2011: 42), vitae obuhvaćaju „prostor života pojedinca s obzirom na njegovu cjelovitost; vita se zanima više za pojedinca, gesta za djela“ (Zlatar 1998: 58).

Na temelju ove distinkcije, Šehovićeve se franjevačke biografske kronike mogu promatrati u okviru žanra vitae. Značajno je napomenuti kako se ovaj žanr razvio po uzoru na srednjovjekovni hagiografski model, a upravo su svetačke legende, odnosno životopisi svetaca-mučenika zapremali značajan dio franjevačkih ljetopisnih zbornika (v. Beljan 2011: 59).

U konstrukciji „života i djela“ fra Vincenca i don Vicka (Gorak okus duše), fra Ilije i fra Andrije (Prokleta ergela), Ilijas-bega u prvom romanu ciklusa Ilijasbegovići te njegova imenjaka u trećem romanu ciklusa, Šehović se koristi fabularnom matricom hagiografskih

\footnotetext{
${ }^{100}$ Uporaba pojmova primarni/sekundarni svjedok preuzeta iz poglavlja o tipologiji svjedoka u knjizi Aleide Assmann Duga senka prošlosti (2011: 102 - 113) te rada Geoffreya Hartmana (2006: 1- 8).
} 
djela, podcrtavajući mučenički položaj protagonista martirološkim leksikom ${ }^{101}$ : pravednik, mučenik, golgota...

Dok su u Gorkome okusu duše i Prokletoj ergeli franjevačke kronike/biografije vezane za članove redovničke zajednice (jedan redovnik ostvaruje kronikalnobiografske zapise o drugome redovniku s ciljem izgradnje modela uzora), u Ilijasbegovićima žanr franjevačke kronike biva smješten u neočekivani kontekst budući da predmet nije član samostanske zajednice već Drugi - Ilijas-beg, čime je otvorena problematika dijaloga i suživota različitih te predodžaba o Bosni i bosanskoj sudbini (v. Begović-Sokolija 2017: 66) ${ }^{102}$.

Ena Begović Sokolija (v. 2017: 60 - 63) razloge posezanja za temom bosanskoga franciskanizma pronalazi kako u poetičkoj sferi, tako i u onoj političkoj.

Šehovićevo oslanjanje na franjevačke kronike prilikom tvorbe imaginativnih svjetova povijesnih romana uključuje kako poetičke „razloge“ - uklapanje u tradiciju „franjevačke pripovjedačke Bosne“ kao svojevrsnoga mikrokanona, tako i one političke - proizašle iz imagološke vizure i pitanja identiteta pojedinaca i skupina.

Kronika je kao model zahvaćanja prošlih događaja vidljiva i u podnaslovu Šehovićeva romana Oslobađanje đavola: Kronika, čime bi se, u okvirima terminologije Gérarda Genetta $^{103}$, moglo reći da su putem podnaslova kao paratekstualne tvorevine naglašene arhitekstualne spojnice (u smislu određene žanrovske pripadnosti).

Kako je već ranije kazano, tematsko-motivska razina ovoga romana vezana je koban potres koji je zadesio Dubrovnik 6. travnja 1667. godine, a o kojem jedan od protagonista - sudac Andro Menčetić, kasnije redovnik dominikanskog samostana i bibliotekarski pomoćnik fra Mavra Sarake - pozicijom svjedoka piše pozamašan rukopis De infernis annotationes (Zapisi o paklu).

Andrino djelo funkcionira u okviru konvencije pronađenoga rukopisa, a donosi kronološki prikaz događaja prije i poslije potresa.

\footnotetext{
${ }^{101}$ Usp. potpoglavlje ovoga rada: „Patnja - provodna figura Šehovićevih povijesnih romana“.

$102 \mathrm{O}$ interkulturnome dijalogu i (ne)mogućnosti suživota različitih više u šestome poglavlju ovoga rada, u dijelu koji se tiče imagološke perspektive (predodžbe o Bosni i Bosancima/Bošnjacima).

${ }^{103}$ U uvodnome dijelu svoje knjige Palimpsest (1982.) Genette navodi i objašnjava pet tipova transtekstualnih odnosa - intertekstualnost, paratekstualnost, metatekstualnost, arhitekstualnost i hipertekstualnost - naglašavajući da ovi vidovi tekstualne transcendencije nisu međusobno strogo odvojeni.

Paratekstualnost se realizira putem naslova, podnaslova, predgovora, pogovora, bilježaka, ilustracija, posveta i sličnih ,sekundarnih signala“, u smislu elemenata jednoga teksta na koje se referira u drugome tekstu (1997: 3). Arhitekstualnost obuhvaća „cjelokupan set generalnih ili transcendentnih kategorija - tip diskurza, moduse izraza, književnih žanrova - iz kojih proizlazi svaki pojedinačni tekst“" (isto: 1).
} 
Fabula romana svojim najvećim dijelom obuhvaća događaje koji su prethodili potresu (̌̌est mjeseci prije potresa) i koji, na neki način, predstavljaju uzroke potresa, a manjim dijelom prikazuje posljedice toga velikoga povijesnog događaja (posljednja poglavlja romana).

Ovaj Šehovićev roman, naslovljen prema Mavrovoj poemi „Oslobađanje đavola“, podnaslovljen je kronikom, čime se upućuje na njegovu diskurzivnu/žanrovsku pripadnost. Pri susretu s ovakvim arhitekstualnim etiketama u primjerice, naslovima, podnaslovima ili predgovorima, valja imati na umu kako ,određivanje generičkoga statusa teksta nije stvar samoga teksta koliko čitatelja, kritike ili publike“ ( Genette1997: 4), dakle generičko smještanje teksta najčešće je u rukama stanovite polazne točke recipijenta.

U kontekstu historiografske kategorizacije H. Whitea, Andrin se rukopis, kao ni ovaj Šehovićev roman ${ }^{104}$, iako podnaslovljeni kronikom, ne mogu smatrati kronikom (u užem smislu). Naime, kako je na početku ovoga potpoglavlja naznačeno, kronike su nedovršene priče, otvorenoga kraja, bez zaokruženosti i moralnoga tona.

Andrina „kronika“ pak, zahvaćajući događaj (potres kao prirodnu katastrofu tumačenu društvenim uzrocima) od izuzetne važnosti za opstanak neke zajednice (grad Dubrovnik), donosi njegove kauzalne aspekte (uzročno-posljedične odnose) te moralnu prosudbu događaja. Riječ je o donošenju cjelovite priče, s početkom, zapletom i krajem, priče u kojoj kraj osvjetljava početak.

Izraz „kronika“ tako u ovome Šehovićevu romanu podrazumijeva jedino aspekt kronologijskoga iznošenja događaja. Sadržaj kronike ovdje je vezan uz govor svjedoka događaja, dakle uz povijest doživljenu ,na vlastitoj koži“: odraz ,velikih“ zbivanja (potres) na „male“ ljudske živote (npr. Andrin tragičan gubitak sina tijekom potresa).

Kroničarske zabilješke značajno mjesto zauzimaju i u Šehovićevu romanu $U$ vod $u$ tvrđavu: Biblija za nevjernike, funkcionirajući kao njegovo posljednje poglavlje.

Riječ je o Sastavljačevoj kratkoj kronici daljnjih zbivanja, pri čemu je uloga sastavljača dana Raulu Mitrovichu, unuku jednoga od protagonista romana - Pepa Mitrovicha.

Raulova kratka kronika obuhvaća kraći period, od siječnja i veljače 1984. godine do 10. lipnja 1985. godine, a odnosi se ponajviše na segmente iz vlastitoga života (spisateljska i predavačka djelatnost, ženidba) te privatnoga života Pepova najboljeg prijatelja Luke (bolest i smrt), kao i na recepciju Pepove drame Tvrđava.

${ }^{104}$ Isto vrijedi i za sagu o Ilijasbegovićima podnaslovljenu kao kronika - Cronica travuniana. 
Kako je već ranije napomenuto, ime „Raul Mitrovich“ povezuje, a istodobno zamagljuje granicu između zbilje unutar teksta i one izvan teksta: riječ je o književnome liku (unuku jednoga od protagonista romana), ali i o imenu koje je na koricama romana ispisano u funkciji autora romana ( pseudonim Feđe Šehovića). ${ }^{105}$

U kontekstu (novo)povijesnoga romana zapisi Hasan-begove žene Sultanije iz drugoga romana Šehovićeva ciklusa Ilijasbegovići (Inšallah) diskurzivno su najbliži zapisima Gizele Weber iz romana Ludwiga Bauera Kratka kronika porodice Weber (1990.).

Gizeline tri bilježnice tvrdih korica, koje dospijevaju u ruke autorskome pripovjedaču etiketirane su kao „obiteljska kronika““106 Weberovih, obitelji „podunavskih Švaba“ koja je živjela u Gradecu skoro sto dvadeset godina.

Poput Gizele, koja je u svojim bilješkama sačuvala sjećanje na Weberove u Gradecu, Sultanija u svojim zapisima kronološki bilježi događaje vezane uz obitelj Ilijasbegovića: međuobiteljske odnose (nesuglasice, pomirenja i sl.), ljubavne peripetije (posebno odnos Sultanije s mužem Hasan-begom) i ženidbe, rođenje potomaka, odnos dvojice prijatelja Hasan-bega i Enesa, proširenja Dvora Ilijasbegovića i gradnja Begovine na maloj visoravni blizu Dvora...

Sultaniji zapisi spominju se i u nastavku sage o Ilijasbegovićima (Begovina, Od Mostara do Den Haaga) u kontekstu zapisa kao mjesta čuvanja prošlosti od zaborava te neizbježnosti prepoznavanja sadašnjeg u prošlom u skladu sa zakonom cikličnosti, odnosno ponovljivosti sudbina, primjerice:

„Njezin ${ }^{107}$ susret s Ilijas-begom umnogome je sličan onome Sultanijinom od prije stoljeća i pol, kao što je i njezin Ilijas-beg bio potpuno sličan stasitom, plavookom čovjeku s prstima u kosi na uljanoj slici u salonu Begovine. Zbog toga su sačuvani Sultanijini zapisi iz XVIII. stoljeća bili za nju veliko i ugodno otkriće.

Iz godine u godinu, sve više je otkrivala sličnosti svojega muža s pretkom Hasanbegom i uviđala mogućnost da bi i sama mogla doživjeti Sultanijinu sudbinu.“ (I: 322)

\footnotetext{
${ }^{105}$ Usp. potpoglavlje ovoga rada pod nazivom „Svjedok kao pripovjedač“.

106, ,...) o nesređenoj i nepotpunoj, iako nadasve opširnoj porodičnoj kronici; vrijednom, ali nedovršenom pokušaju, ispisanom Gizelinom rukom u tri bilježnice tvrdih korica.“ (Bauer 2001: 7, istaknula D. M. L.)

${ }^{107}$ Misli se na usporedbu odnosa supružnika Alme i Ilijas-bega u Begovini s odnosom Sultanije i Hasan-bega opisanima u Inšallahu.
} 
Iz dosad navedenoga vidljivo je kako kronikalni zapisi obuhvaćaju značajno mjesto Šehovićeve poetike budući da su na određene načine prisutni u svim povijesnim romanima ovoga pisca.

Značenje kronika u Šehovića ne poklapa se s definicijskim oznakama kronika od strane H. Whitea, istaknutima na početku ovoga potpoglavlja. Kronike u Šehovićevim romanima tako ne predstavljaju nedovršene, otvorene priče bez zaokruženosti i moralnoga stava.

U konstelaciji s idejnim slojem romana, Šehovićeve bi se kronike mogle okarakterizirati i Fabrijevom kategorijom „kronisterije“ ${ }^{108}$, preuzete još od Danuncijade Viktora Cara Emina: kronike (tal. cronaca - ljetopis) udružene s histerijom (tal. isteria), čime se naznačava histerična priroda svake historije, povijest koja je uvijek tek (ponovljiva) ludost, jalovost i smrt (v. Nemec 2003: 286).

Kronike se u Šehovićevim romanima najčešće pojavljuju u vidu tzv. franjevačkih zapisa koji predstavljaju biografije pojedinaca jobovske sudbine (kronika fra Mavra S. u Gorkom okusu duše, zapisi fra Andrije i fra Marka u Prokletoj ergeli, zapisi fra Matije Kopčića, fra Ivana Lovrenovića i fra Petra u Ilijasbegovićima), zatim kao obiteljska kronika (Sultanijini zapisi u Ilijasbegovićima i kratka kronika Raula Mitrovicha u Uvodu u tvrđavu) ili pak kronika zbivanja sudbonosnih za određeni grad, točnije njegove stanovnike (veliki dubrovački potres u romanu Oslobađanje đavola: Kronika).

Bez obzira na tip kronikalnoga zapisa u Šehovićevim povijesnim romanima, svima im je zajedničko kronološko bilježenje događaja te oblikovanje personaliziranoga povijesnog iskustva posredstvom iskaza svjedoka - uvijek je riječ o svojevrsnim intimnim kronikama.

\footnotetext{
${ }^{108}$ Prvi dio Jadranske trilogije Nedjeljka Fabrija, roman Vježbanje života, nosi podnaslov „Kronisterija“. I u drugim romanima Trilogije Fabrio će se poslužiti izrazom „kronisterija“, primjerice u Triemeronu: „Ecije Grimani, jedini koji je još mogao pamtiti kuće u kronisteriji svoje obitelji..." (2002: 63).

Valja napomenuti kako, unatoč izrazu „kronisterija“, Fabrijev pripovjedač u Vježbanju života (ali i ostalim romanima ovoga pisca) izbjegava strogo kronološko iznošenje događaja „odabirući preskoke omeđene vremenskim rasponom od dvjesto godina“" (Matanović 1998: 280).
} 


\subsubsection{Dnevnik}

Prilikom pokušaja definiranja autobiografije ${ }^{109}$, Philippe Lejeune dnevnik (uz memoare, biografiju, osobni roman, autobiografsku pjesmu, autoportret ili esej) smješta u kategoriju autobiografiji bliskoga žanra budući da dnevnik ne udovoljava jednome od zahtjeva autobiografije (u užem smislu) - retrospektivnoj perspektivi (2000: 202 - 203). Naime, autobiografija je „ustrojena s integralne vremenske distance, koja dopušta pregled nad nekakvom cjelinom života, za razliku od dnevnika koji se ustrojava u manjim uzastopnim vremenskim razmacima“ (Biti 2000a: 18). Specifičnost dijarističkoga zapisa tako leži u pokušaju simulacije istodobnosti događanja i pisanja o tom događanju (Zlatar 1998: 91).

Helena Sablić Tomić dnevnik kao žanr ocrtava mnogo fleksibilnijim definicijskim oznakama promatrajući ga kao jedan od „modela autobiografske proze“ (2002, 2008). Pri tom, unatoč privilegiranosti točnosti i pouzdanosti informacija u dnevniku, tragom teoretičara Manfreda Jürgensena (v.1991: 231 - 247) naglašava narativnu narav dnevničkih zapisa te njihovo svojstvo objedinjavanja dokumentarnosti i subjektivnosti, ,intimnog i javnog“(v. Sablić Tomić 2008: 115).

Manfred Jürgensen donosi sljedeću definiciju dnevnika:

"Dnevnik registrira dnevne poticaje koje Ja doživljava istovremeno kao privatni individuum i kao društveni suvremenik. Dnevnik postaje povijesnim svjedočanstvom toga Ja: ono u dnevniku svjedoči o sebi i ‘svome' svijetu, o sebi i 'svome' vremenu. U tom smislu dnevnik je reprezentativno-subjektivna povjesnica; u njegovim zabilješkama čitatelj susreće individualnu historijsku egzistenciju.” (1991: 234)

Upravo je model dnevnika kao „reprezentativno-subjektivne povjesnice“ Feđa Šehović iskoristio u svome romanu Uvod u tvrđavu: Biblija za nevjernike kreirajući poglavlje $I z$

\section{Lukinih dnevničkih zapisa.}

Prijedlog „,iz“ vidljiv u naslovu dnevnika upućuje na izbor iz dnevničkih zapisa Luke Božidarevića (jednoga od protagonista romana), pri čemu se kao instanca koja je intervenirala u sam izbor nameće „sastavljač“, odnosno neka vrsta urednika/priređivača svih rukopisa u

\footnotetext{
109 „Retrospektivni prozni tekst kojim neka stvarna osoba pripovijeda vlastito življenje, naglašavajući svoj osobni život, a osobito povijest razvoja svoje ličnosti.“ (2000: 202)
} 
romanu - Raul Mitrovich (unuk protagonista Pepa Mitrovicha i Šehovićev pseudonimski izbor).

Lukine dnevničke bilješke obuhvaćaju razdoblje od dvadesetak godina (10. 10. 1960 3. 11. 1983.), a spacijalno nastaju na relaciji Zagreb - SAD - Pariz.

S obzirom da je riječ o simulaciji priređivačeva/sastavljačeva izbora ,iz zapisa“, uočava se različit vremenski raspon između pojedinih dnevničkih natuknica: od učestalih dnevničkih bilježenja (npr. 10. 10. 1960. - 15. 10. 1960. - 24. 10. 1960.) do bilježaka među kojima je širok vremenski raspon (npr. 4. 4. 1972. - 10. 10. 1981.).

Ovakve intervencije u temporalnu dimenziju imaju narativnu funkciju s obzirom da Šehović njima ostvaruje potrebno vremensko premošćivanje te ,zgusnutost“ ili „rastezanje“ segmenata priče.

Uz to, Lukine dnevničke bilješke pripovjedno se, po načelu ,što je dalje bilo“, nadovezuju na poglavlje koje im je prethodilo (Epistolar - pisma Luke Božidarevića), a prethode posljednjem poglavlju romana. Tako „,sastavljač“ (Raul Mitrovich) piše „kratku kroniku daljnjih zbivanja““ nakon što Luki zbog Parkinsonove bolesti više nije omogućeno vođenje dijarističkih zapisa.

Na koji se način diskurzivno različiti zapisi ovog Šehovićeva romana nadovezuju jedan na drugoga u službi ulančanoga kazivanja priče pokazat će završne rečenice Lukina dnevnika i početne rečenice sastavljačeve kronike koja će uslijediti nakon dnevničkih zapisa:

„3. 11. 1983.

(...) Imao bih još mnogo toga napisati, ali ne mogu, ruke mi, čini mi se, sve više drhte. Poslije jučerašnjeg pregleda, doktor vjeruje da se radi o Parkinsonovoj bolesti i da bi moglo doći do stanovitog pogoršanja. Che sera-sera." (UUT: 246)

„Siječanj i veljača 1984.

Parkinsonova bolest uzela je kod Luke toliko maha da uopće nije u stanju pisati. Umjesto pisama, obavlja sa mnom česte i duge telefonske razgovore.“ (UUT: 247)

S obzirom na tematsku tipologiju dnevnika prema H. Sablić Tomić (2002: 105 - 146), Lukine dnevničke bilješke u najvećoj mjeri pokazuju osobitosti privatnih dnevnika. 
Luko je uglavnom usmjeren na privatnu sferu svojega života, zbog čega su dnevničke natuknice ispunjene pojedinostima iz Lukina ljubavnoga života (veza sa tamnoputom aktivistkinjom Sarom te mlađahnom sveučilišnom knjižničarkom Alice), obiteljskim odnosima (mlađi brat Nikša koji živi u Americi), prijateljskim kontaktima (Pepov unuk Raul Mitrovich, izdavač Frank, Francuz Rene, Litvanac Maironis, srpski novinar Danilo...), poslovnim peripetijama (posebno posao na Sveučilištu u SAD-u gdje Luko radi kao profesor književnosti), zdravstvenim stanjem (posljedice zračenja u logoru, Parkinsonova bolest pred kraj života) itd.

Uz intimnu sferu, Lukin dnevnik oblikuje i onu javnu; postaje portret socijalnog, političkog i kulturnoga vremena u kojem Luko kao subjekt ostvaruje i svoj socijalni identitet (v. Sablić Tomić 2002: 120), čime ovaj dnevnik poprima i konture socijalnoga dnevnika. Mozaično se konstruira slika Jugoslavije poslije Drugoga svjetskoga rata (od šezdesetih do osamdesetih godina) u ozračju komunističke ideologije, ali i iskustvo hrvatske emigracije u Americi.

Opisom Lukina susreta s tzv. „književnim bardom“ (aluzije na Miroslava Krležu) poseban naglasak stavljen je na književne prilike u Jugoslaviji toga vremena (rasprava između pisaca starije i mlađe generacije, problem umjetničke slobode i dogmi u umjetnosti). Na ovome tragu značajna je i recepcija Lukine književne produkcije, kako one testimonijalnoga karaktera (pisana svjedočenja o logorskim iskustvima), tako i one književnopovijesnoga karaktera (Pregled suvremene književnosti naroda takozvanog istočnoevropskog socijalističkog bloka).

Luko postaje objekt hajke u domovini, ali i izvan nje, čime Šehović nastavlja problematiku odnosa pisac - vlast započetu još u prva dva romana dubrovačke trilogije.

Tematika književne recepcije proširena je reakcijama na Pepovu dramu Tvrđava: Biblija za nevjernike, njezine prijevode i kazališna uprizorenja.

Lukine dnevničke natuknice mjestimično su prožete i filozofskim promišljanjima o univerzalnim kategorijama (starost, smrt, zaborav) ${ }^{110}$, a pod utjecajem nepovoljnih političkopovijesnih prilika aktualan postaje odnos (umjetničkih) ideala i vladajuće ideologije, zbog čega su stranice Lukina dnevnika postale i mjesto izražavanja poetičkih postulata ${ }^{111}$.

\footnotetext{
${ }^{110}$ Npr. „Dok smo u mladosti opsjednuti mislima o budućnosti, u srednjoj dobi o prošlosti, u starosti nas isključivo zanima sadašnjost i obično samo vlastita. To je neki neshvatljivi prirodni put duhovnog rasta $i$ umiranja u čovjeku: od usplahirene poletne mašte, preko smirena provjeravanja prijeđena puta i svođenja životnih računa, do potpune zaokupljenosti golim životom i dnevnim preživljavanjem. “ (UUT: 243 - 244) ${ }^{111}$ Npr. „Postavio sam pitanje morala, bez kojeg se pisac ne može zamisliti, onoga koji prije svega podrazumijeva sumnju i istinoljubivost, ne plašeći se nikakvih posljedica.“(UUT: 204)
} 
Bilo da je riječ o likovima znamenitih, velikih povijesnih ličnosti, poput biskupa Josipa Jurja Strossmayera u romanu Zlatousti (1993.) Stjepana Tomaša, likovima pojedinaca od rubnog društvenoga značaja poput profesora književnosti i pisca Luke Božidarevića iz Šehovićeva Uvoda u tvrđavu, ili likovima povijesno potpuno nebitnih, poput žene, ljubavnice i kućanice Bore Grimani iz Fabrijeva Triemerona (2002.) ${ }^{112}$, dnevničke bilješke u hrvatskom novopovijesnom romanu pozicijom dijarista kao svjedoka događaja sudjeluju u oslikavanju destruktivnoga djelovanja ideoloških mehanizama na egzistenciju povijesnih subjekata.

U svojim dnevničkim osvrtima na događaje oko sebe Šehovićev Luko samo podcrtava svoj status ,ideološkog nevjernika“ prisutan u svim zapisima romana Uvod u tvrđavu; Bore Grimani rečenicama uznemirene intonacije svjedoči razoran ulazak politike u privatni prostor/dom onih koji se politikom i ne bave (saslušanja, oduzimanje imovine);

Strossmayerovi dijaristički zapisi razotkrivaju donkihotovsko otrježnjenje od ideje zajednice svih Južnih Slavena te bratstva istočne i zapadne Crkve ${ }^{113}$.

Ukratko, osim što su „namjerna prisjećanja u dnevničkim bilješkama zaista vrijedan katalog društvenih zbivanja“ (Sablić Tomić 2008: 123), dnevnik funkcionira i kao prostor osobitog aktivizma pojedinca (v. Sablić Tomić 2002: 125 - 126), gdje ono intimno i subjektivno često kreira subverzivan odnos prema javnoj, službeno nametnutoj slici povijesne istine.

\footnotetext{
„(...) zaključio sam da je umjetnost po prirodi elitistička, da isključuje jednakost i uzdiže pojedinca, da je zapravo nešto najosobnije.“ (UUT: 234)

${ }^{112}$ Nedjeljko Fabrio Borine dnevničke bilješke donosi na talijanskome jeziku te u prijevodu na hrvatski jezik, uz napomenu u okviru osnovnoga teksta:

Bore Grimani: Diario. Nota di casa. (Dnevnik. Kućne bilješke). 11 olovkom i tintom izvorno pisanih stranica formata 9X14. Četiri posljednje stranice iščupane i zauvijek izgubljene, Doslovno prepisao i preveo pisac.

${ }^{113}$ Iako Strossmayerov dnevnik u romanu Stjepana Tomaša Zlatousti ne obilježava tipičan dnevnički intimistički, pa ni ispovjedni diskurs (v. Matanović 2003: 133), pripovjedač svojim komentarima konstatira kako i veliki Strossmayer katkad ,kuka nad svojom jobovskom sudbinom“ (Tomaš 1993: 144).

Listajući stranice Strossmayerovih tajnih dnevničkih zapisa što mu ih je svećenik Rufin u povjerenju predao, pripovjedač (televizijski novinar koji radi reportažu o biskupu), uočava povijesni niz donkihotovskih boraca, aludirajući i time na povijesnu ponovljivost:

„Prije stoljeće i pol Starčević bijaše don Quijote, sa svojim štitonošom Kvaternikom. Danas bi don Quijote bio Strossmayer sa svojim štitonošom Račkim.“(Tomaš 1993: 193)

„Srljali su Hrvati za slavenstvom, za južnoslavenstvom, za jugoslavenstvom nezaustavljivo. Strossmayer i Rački imali su u tome prethodnike, imat će i sljedbenike.“(Tomaš 1993: 176)
} 


\subsubsection{Epistolarni zapisi}

Začetak novopovijesne varijante hrvatskoga povijesnog romana Julijana Matanović (v. 1995: 101 - 102; 1998: 142 - 166; 2003: 9 - 38) prepoznaje upravo u prizoru uništenja jednoga pisma unutar romana Milutina Cihlara Nehajeva Vuci (1928.).

Riječ je o trenutku kada gradski kroničar Mario Sanudo, koji inače skuplja doslovno sve što bi moglo u budućnosti poslužiti kao dokument za (re)konstrukciju određenoga segmenta prošlosti, gužva pismo koje je Fran Krsto Frankopan iz zatočeništva poslao voljenoj ženi Apoloniji. Ovakva Sanudova reakcija, koja predstavlja stanovit zahvat u potencijalnu sliku prošlosti, proizlazi iz činjenice da u pismu nije bilo onoga što je povijest očekivala od ličnosti kao što je Frankopan.

Dok su u povijesnoj varijanti hrvatskoga povijesnog romana inkorporirana pisma imala povijesnu važnost, dakle funkcionirala su kao značajan povijesni dokument, $u$ novopovijesnim romanima pisma nose oznaku privatnosti (v. Matanović 2003: 34). Epistolarni zapisi u hrvatskome novopovijesnom romanu nerijetko imaju funkciju razotkrivanja obične, ljudske dimenzije onih koji predstavljaju određene povijesne veličine; recipijentu razotkrivaju neočekivanu intimu onih koji su percipirani isključivo kao službeno zadana javna slika.

U tome kontekstu, primjerice, Ivan Aralica u romanu Psi u trgovištu (1979.) prvo poglavlje oblikuje posredstvom (pseudo)epistolarnih zapisa što ih je lik šibenskog humanista i svećenika Antuna Vrančića slao bratu Mihovilu. Pisma, između ostaloga, karakteriziraju Vrančića kao strastvenoga obožavatelja žena.

Poput Araličina znamenitoga Antuna Vrančića, i biskup Josip Juraj Strossmayer u Zlatoustome (1993.) Stjepana Tomaša, kao i ban Josip Jelačić u romanu Ivice Ivanca $U$ službi Josipa baruna Jelačića (1970./1990.), upravo su preko ljubavne korespondencije (izravno zastupljene ili komentirane od strane pripovjedača) prikazani (i) kao obični ljudi, muškarci „od krvi i mesa“, naklonjeni ženama i životnim užitcima općenito.

U romanu Buna Janusa Panonniusa (1992.) Ivana Supeka, među ostalim, pisma upućena pjesniku Janusu Pannoniusu sudjeluju u nekoj vrsti Pannoniusove oporuke, koju metodom kompilacije raznovrsnih iskaza pokušava konstruirati njegov sluga i prijatelj, klesar Miroslav iz Travničke župe.

U povijesnim romanima Feđe Šehovića, kao i nekih drugih pisaca hrvatskih novopovijesnih romana, pisma ne šalju i ne primaju velike povijesne ličnosti, na tragu gore 
spomenutih; epistolarni zapisi ne razotkrivaju službenoj povijesti (još) nepoznate/nepoželjne intimne zakutke povijesno značajnih subjekata.

Feđa Šehović uvijek je usredotočen na uobličavanje sudbine onih čije se ime ne može provjeriti u službenoj historiografiji, koji su tek ,jedni od nas“, metaforički rečeno - povijesno bezimeni.

Za razliku od dnevnika, u kojem je subjekt prvenstveno okrenut sebi (čak i kad piše s namjerom objavljivanja), nositelj pisma u vidu ima svoj adresat, pismo je neizbježno upućeno drugome, zbog čega se na razini forme uvijek uočava odnos pošiljatelj - primatelj (Sablić Tomić 2008: 126).

Epistolarnu strategiju Feđa Šehović iskoristio je u svojim povijesnim romanima Oslobađanje đavola i Uvod u tvrđavu.

S obzirom na tipologiju pisama prema Heleni Sablić Tomić (v. 2002: 175 - 184) ${ }^{114}$, Šehović se koristi tzv. privatnim pismima, u kojima „horizont očekivanja primatelja s kojim je subjekt epistolarnog diskursa u privatnoj ili socijalnoj vezi jest autorefleksija o intimnim stanjima i primarnoj egzistenciji“ (isto: 175).

Posljednje poglavlje (26.) Oslobađanja đavola sadrži epistolarne fragmente: „Iz pisma pariškom bankaru Charpentieru, što mu ga je nekoliko dana poslije velike trešnje $u$ Dubrovniku 1667. godine pisao iz Venecije gospodin Harden“ i „Iz pisma ser Francisca Paolija de Bobalija, 18. travnja 1667.“.

Za razliku od gospodina Hardena, sporednoga lika u romanu, Francisco de Bobali nema status lika, dakle nije nositelj ni jednoga segmenta fabularnoga razvoja. Oboje, međutim, posredstvom gore navedenih epistolarnih zapisa, posjeduju status svjedoka velikoga dubrovačkoga potresa. Po svome sadržaju njihova pisma predstavljaju svjedočenje o posljedicama koje je potres ostavio na njihove osobne živote, ali i grad Dubrovnik općenito. Obojica u danima nakon potresa razotkrivaju fenomen „oslobađanja đavola“, ali $u$ ljudima, koji se manifestirao u tolikoj gramzivosti za novcem da je Dubrovnik zahvaćen valom pljačkanja, pa i ubojstava. Harden i Bobali izvještavaju iz prve ruke, o onome što su vidjeli vlastitim očima i čuli vlastitim ušima. ${ }^{115}$

\footnotetext{
${ }^{114}$ H. Sablić Tomić, s obzirom na sadržaj, namjeru i horizont očekivanja čitatelja, navodi sljedeću tipologiju pisama: privatna pisma, otvorena pisma $i$ apeli.

${ }^{115}$ Usporedi na primjer: a) iz pisma gospodina Hardena: „Dugo smo se tako natezali, dok oni najzad na najsuroviji način rekoše da nas neće spasiti jer nemamo novaca. U tom trenutku sjetih se da na ruci imam prsten s dva dijamanta... (...) Prošli smo kroz pakao ruševina i vidjeli najstrašnije prizore i slušali bolne glasove nevidljivih samrtnika.“(OĐ: 165 - 166)
} 
Epistolarni fragmenti inkorporirani u roman popraćeni su i fusnotama koje, među ostalim, proizvode i efekt autentičnosti i uvjerljivosti. ${ }^{116}$

Čitavo jedno poglavlje romana Uvod u tvrđavu nosi naziv Epistolar. Sadržava pisma protagonista, u najvećoj mjeri Lukina pisma bratu Nikši, sestri Madi i prijatelju Pepu, a manjim dijelom Josipova (Pepova) pisma prijatelju Luki.

U samome romanu pisma slijede nakon niza Lukinih i Pepovih testimonijalnih logorskih zapisa (Ropstvo po Luki I - VII, Muke po Pepu), dakle obuhvaćaju vrijeme Lukina i Pepova izlaska iz različitih vidova ropstva i povratka u stvarnost kreiranu posljedicama Drugoga svjetskoga rata.

Svojim su sadržajem epistolarni zapisi usredotočeni na najintimnije prostore protagonista, ponajviše na motive Pepove bolesti i smrti, posredovane i Lukom i Pepom kao fokalizatorom. Osim toga, tematsko-motivski pisma obuhvaćaju i širi društveni kontekst usredotočenošću na aktualna književna pitanja poslijeratne Europe. Pri tome je u fokusu Lukina i Pepova književna produkcija: izdavanje i recepcija Lukine testimonijalne literature (Kronika ropstva, Sibirski zapisi) te Pepove Tvrđave: Biblije za nevjernike.

Poput pisama u Oslobađanju đavola, ni pisma u Uvodu u tvrđavu nisu obilježena svim stereotipnim formalnim epistolarnim karakteristikama: datiranjem, oslovljavanjem primatelja na početku, objašnjavanjem povoda pisanju, iznošenjem sadržaja te potpisom pošiljatelja na samome kraju (v. Sablić Tomić 2002: 174).

Ipak, dok je iz naslova pisama u Oslobađanju đavola vidljivo njihovo datiranje, u Uvodu u tvrđavu naslovi razotkrivaju tek primatelja pisama. Inače, što je zamjetljivo i iz prethodne napomene, Šehović u Uvodu u tvrđavu mnogo fleksibilnije postupa s temporalnim kategorijama nego što to čini u Oslobađanju đavola, podnaslovljenome Kronika. ${ }^{117}$ Vremenski su, u oba Šehovićeva navedena povijesna romana, epistolarni zapisi nizani u skladu sa zahtjevima priče, po načelu ,što je dalje bilo“.

I uporabom epistolarne forme Šehović je iskoristio poziciju svjedoka, ne samo onih najintimnijih životnih situacija, nego i situacija od društvenoga značaja. Upravo u

\footnotetext{
b) iz pisma ser Francisca de Bobalija: „Pobjegao sam na trg ispred Katedrale i kroz suzne oči vidio napola zatrpane mrtve ili žive ljude. (...) Bože, zašto me ostavi u životu da gledam ovakvu bijedu sličnu razorenu Jeruzalemu ili spaljenoj Troji...“(OĐ: 166 - 167)

${ }^{116} \mathrm{O}$ fusnotama više u narednome potpoglavlju.

${ }^{117}$ U Oslobađanju đavola, u skladu s podnaslovom romana, zamjetne su precizne vremenske koordinate, npr. „6. travnja 1667. godine“ (OĐ: 7); „na dan svete Lucije, 13. prosinca 1666.“(ОĐ: 29); „oko deset sati prije podne, u subotu 2. travnja 1667.“(ОĐ: 131)...

U najvećem dijelu Uvoda u tvrđavu (izuzetak su dnevnički zapisi i sastavljačeva kronika daljnjih zbivanja) kategorija vremena okvirno je predočena (bez brojčanih naznaka), s osloncem na recipijentovu upućenost $u$ određene povijesne prilike, npr. „Dan ujedinjenja osvanuo je lijep i sunčan“ (UUT: 26); „,vihori ruskog Oktobra“ (UUT: 51); ,slavi se trogodišnjica pobjede nad Hitlerom“ (UUT: 142)...
} 
epistolarnome zapisu, više nego u bilo kojem drugom autobiografskome modelu i tipu (H. Sablić Tomić), do izražaja dolazi upućenost recipijentu, odnosno apelativnost kao specifičnost svakog testimonijalnoga akta.

\subsubsection{Autobiografski zapisi (u užem smislu)}

Ne postavljajući kao domet iscrpnu problematizaciju žanrovskih zavrzlama ${ }^{118}$ vezanih uz autobiografiju, u ovome će se dijelu rada o autobiografskome govoriti prvenstveno na razini samodefinicije samoga termina (netko piše o vlastitome životu), imajući u vidu dvije okvirne strategije pisanja o vlastitome životu: pripovjednu strategiju (autobiografska proza u užem smislu, dnevnici, memoari, pisma) i esejističko-refleksivnu (eseji, kolumne, novinski članci) (Sablić Tomić 2002: 19 - 28).

U ovome bi kontekstu fusnota ${ }^{119}$ na završnoj stranici Dubrovačkoga intermezza (četvrti roman Ilijasbegovića) podrazumijevala simulaciju autobiografske proze (u užem smislu) u završnome dijelu Begovine - trećem romanu Ilijasbegovića (od 32. poglavlja do kraja romana) te u čitavome Dubrovačkome intermezzu.

Navedena fusnota upućuje na identičnost instanci autor - pripovjedač - lik, čime je čitatelju ponuđen tzv. autobiografski sporazum (v. Lejeune 2000: 201 - 236) svojstven svakom autobiografskome pisanju.

Ilijas, unuk Ilijas-bega (protagonist prvoga dijela Begovine), u gore izdvojenim dijelovima Ilijasbegovića retrospektivno zahvaća zbivanja vezana kako za intimnu sferu svojega života (obiteljski odnosi, selidba iz Trebinja u Dubrovnik, prijateljstvo, ljubav, školovanje, hobiji i interesi), tako i za povijesnu pozornicu (izmjenjivanje političkih autoriteta - nacizam/komunizam), međusobno ih ispreplićući i upućujući na neizbježnost njihova suodnosa u kojem pojedinačna sudbina uvijek biva ugrožena povijesnom vrtnjom.

\footnotetext{
${ }^{118}$ Termin autobiografija počinje se sve više ,upotrebljavati u svome izvedenom, pridjevskom obliku autobiografski diskurs, akt, figura - i više se ne postavlja pitanje na temelju koje supstance (žanrovske?) jest izveden taj pridjev“ (Zlatar 2000: 34).

119 „Završavajući u Zagrebu ovu pripovijest o svojem dječaštvu, točno tri godine nakon mojeg dolaska u Mostar da nastavim osmi razred gimnazije i maturiram, prisjetio sam se Sarajkina gatanja u vlaku. Nisam zbog toga osjetio strah da se obmanjujem željom za pisanjem. Jedino se bojah od mogućnosti iskrivljavanja istine u svojim sjećanjima.“" (I: 724)
} 
Upravo u skladu sa zahtjevima autobiografskoga diskursa, Ilijas u svojim zapisima naglasak stavlja na autorefleksivno promišljanje o problematici vlastitoga identiteta, o razvoju ,ja“, putem narativnih strategija.

„Počivajući na tjelesnom i vremenskom kontinuitetu instanci doživljajnog i pripovjednog subjekta“ (Biti 2000a: 18), ali i „,disonantnosti između (te) dvije narativne instance ili perspektive, junakove i pripovjedačeve - jer o prošlim događajima ne izvještava junak, autor kakav je bio, već narator, tj. autor kakav je sada“" (Duvnjak Radić 2011: 33), autobiografski zapis uvijek uključuje tzv. sindrom naknadne pameti (v. npr. Sablić Tomić 2002: 20).

Proleptičkim segmentima Ilijas-pripovjedač katkad naglašava kako će mu mnogo toga biti jasnije tek naknadno, kad odraste, npr. :

„Znao sam ja već da je dedo i prije rata imao svoj auto, istina samo toliko, jer ću tek dosta godina kasnije saznati i o sudbini tog automobila kao i o svemu vezanom uz njega i dedovo kockanje u Dubrovniku.“(470)

Na tragu toga, Ilijas-pripovjedač iz nadređene se i sveznajuće pozicije nerijetko moralizatorski osvrće na svoje zablude iz mladosti, dakle na misli i djela Ilijasa-junaka:

„...osjećao sam gorčinu i silno mrzio okrutne ubojice, naciste. Sramio sam se svojega dječjeg zanosa“ (650)

„Činilo mi se da se konačno ukida naš grijeh vjerskog otpadništva u čemu sam vidio osobito svijetlu stranu komunizma. Činilo mi se, kažem.““(654)...

„Svijet drugih u autobiografskoj prozi nije samo svijet različitih junaka autorova života, to je i svijet pripovjedača. Jedan dio svoje biografije autor saznaje od drugih.“ (Duvnjak Radić 2011: 31) Tako su u Ilijasovo kazivanje ugrađene i priče drugih: zbivanja koja nije mogao upamtiti jer je bio premalen (npr. priča o rođenju), priče o događajima iz obiteljske i nacionalne povijesti kojima nije prisustvovao ili ih u određenoj dobi nije mogao zapamtiti i/ili shvatiti. 
Te priče, uglavnom posredovane Ilijasovim prepričavanjem, dakle prebačene $\mathrm{u}$ neupravni govor ${ }^{120}$, još jednom ukazuju na neizbježnu simbiozu vlastite i tuđe riječi pri svakoj kreaciji tekstualnoga, pa čak i teksta o vlastitome životu.

Referirajući se na Jamesa Olneya, Andrea Zlatar napominje kako je pedesetih i šezdesetih godina 20. stoljeća usmjerenost autobiografije počivala na samome životu (bios), od kraja šedesetih i tijekom sedamdesetih postalo je problematično samo ,ja“ koje piše (auto), da bi od kraja sedamdesetih do naših dana u fokusu bio sam čin pisanja (grafija) (1998: 7). Ilijasovi autobiografski zapisi, iščitava se iz ranije navedene (auto)metatekstualne fusnote, naglasak stavljaju upravo na izazov pretvorbe života u tekst, u priču o životu, u ,pripovijest o dječaštvu“ (v. fusnotu).

Pri tome se, kako to ističe Mirna Velčić (1991: 78 - 133), nameće paralela osobne povijesti i javne povijesti, odnosno autobiografskoga i historiografskoga diskursa - uvijek je riječ o potrebi da se izgradi odnos prema prošlosti iz pozicije sadašnjosti, bilo na mikro ili makro planu. Kao što povjesničar, vođen tragovima prošlosti (najčešće tekstualne prirode), pokušava konstruirati zaokruženu priču o toj prošlosti, tako i autobiograf (ponajviše manjkavim mehanizmom sjećanja) od fragmenata prošlosti nastoji posredstvom jezika uobličiti cjelovitu pripovijest o svome dotadašnjem životu.

Mada se iskrenost $\mathrm{i}$ istinitost redovito podrazumijevaju uvjetima autobiografskoga diskursa (Zlatar 2000: 199), što je vidljivo iz Ilijasova straha „od mogućnosti iskrivljavanja istine u svojim sjećanjima“ (v. fusnotu), autobiografija nije (samo) referentni žanr, upućen na izvantekstualnu zbilju. Autobiografija uvijek podrazumijeva određen stupanj fikcionalnosti: „Između te dvije krajnosti, ugovornog „,vjerujte“ i ludičkog ,zamislite“ meandrira svaka autobiografija.“ (Duvnjak Radić 2011: 49) Zato, iako pretendira na istinu kao očekivani autobiografski topos, Ilijas-pripovjedač naznačava i da piše pripovijest, čime je naglašena fiktivna strana autobiografskoga:

\footnotetext{
${ }^{120}$ U 34. poglavlju Begovine donose se pripovijesti o uljanim slikama Ilijasovih predaka - Hasan-bega iz 18. stoljeća te djeda Ilijas-bega iz prve polovice 20. stoljeća:

„Nena Almasa je mnogo znala o dedovom ratovanju na Soči i Piavi, ali njezino pričanje o strašnim uvjetima ratovanja na Soči ili slavnoj pobjedi kod Kobarida djelovala je šturo... (...) Zbog toga, zamolio bi nenu da mi priča o onom što je ona lijepo i zanimljivo pričala, a što je u meni uvijek i iznova budilo znatiželju. Bile su to pripovijesti o uljanim slikama naših davnih predaka..."(461)

U 33. poglavlju Dubrovačkoga intermezza Husein, vozač Ilijasova oca Enver-bega, priča o Enverovoj smrti na Bleiburgu:

„Njegovo pričanje mi se činilo osobitim. Nije počeo od Kulina bana, čega sam se pribojavao, već poput pravog pisca, od trenutka koji sam želio. (...) Husein je vidio kako se moj otac naglo ustao, a odmah zatim pao natraške u rov presahle vododerine. Među ostalima i Huseina su odredili da zatrpava mrtvace.“ (657)
} 
„Veza između 'ja' pripovjedača i 'ja' sudionika zbiljskih događaja, između tekstnog i historijskog subjekta, između pripovijedanja i izvanjezične zbilje ne može biti faktična, prirodna i po sebi razumljiva, nego je proizvedena, i prema tome problematična. Zato bi se moglo reći da je autobiografija diskurs, a budući da je diskurs, ona je utemeljena na fikciji.“(Velčić 1991: 29) ${ }^{121}$

Konstruirajući u najvećoj mjeri lik Ilijasa (protagonista velikog dijela ciklusa o Ilijasbegovićima) pozicijom autobiografskoga ,ja“", koje odnos prema povijesnome realizira svjedočenjem razvoja vlastitoga identiteta na prepletu velikih povijesnih zbivanja (Drugi svjetski rat i totalitarni režimi), Feđa Šehović i na ovaj način naznačava privilegirani status subjektiviziranoga povijesnog iskustva u okviru bilo kojeg pokušaja govora o povijesnome.

\subsubsection{Testimonijalna literatura}

Baveći se književnoteorijskim i kulturnoantropološkim aspektima svjedočenja (Domovinski rat), Renata Jambrešić Kirin naglašava razliku između svjedočenja kao „istinosnog izvještaja o zbilji“ (svjedočenje kao povijesni izvor ili kaznenopravni dokaz) te literature svjedočenja kao podvrste autobiografsko-memoarskoga diskursa (1999: 269) ${ }^{122}$. Za razliku od uporišta autobiografskoga subjekta u samome sebi, „,testimonijalni subjekt bliži je memoarskom polu autobiografskog nefikcionalnog pripovijedanja usmjerenog na društveno-povijesno i etički relevantan sadržaj“ (25), stoga „svjedočenja, u većoj mjeri nego bilo koji drugi autobiografski iskaz, izranjaju iz političkoga konteksta i odgovaraju na specifičan sklop političkih uvjeta i komunikacijskih zadatosti““(26).

Upravo se zato testimonijalna literatura oblikovala „u ritmu masovnog političkog nasilja koja se smjenjuju od 1914. do danas“ (Subašić Thomas 2014:1), pri čemu su na razini europske, ali i svjetske recepcije najpoznatije testimonijalne refleksije na stradanja u Drugome svjetskom ratu (Ana Frank, Primo Levi, Tadeusz Borowski, Jorge Semprun...).

\footnotetext{
${ }^{121} \mathrm{Na}$ ovome mjestu može se podsjetiti na stajalište američkoga filozofa i povjesničara Haydena Whitea kako je i povijest uvijek priča (pri/povijest), a priče kao činjenične tvrdnje, lingvističke su tvorevine i pripadaju redu diskursa (2004: 621 - 635).

${ }^{122} \mathrm{U}$ tu svrhu razlikuje terminološki svjedočanstvo/svjedočenje. Vidi poglavlje ovoga rada „Svjedočenje, svjedok: teorijska kontekstualizacija“.
} 
Natka Badurina (2010: 189 - 191) popularizaciju tekstova svjedočenja od kraja prošloga stoljeća tumači povijesno-političkim razlozima (intelektualna povijest odnosa Zapada prema holokaustu) te onima književnoteorijskima (nov status autobiografije u književnoj znanosti): „Svjedočenja su krajem prošloga stoljeća dobila nov status u književnosti, a književna znanost uz ostale humanističke discipline sudjeluje u dobu svjedoka“"(199).

U najvećem dijelu Šehovićeva romana Uvod u tvrđavu: Biblija za nevjernike zamjetno je simuliranje upravo opisanoga diskursa - literature svjedočenja.

Poglavljima pod nazivom Ropstvo po Luki (u sedam dijelova) iznesena je mučna višegodišnja svakodnevnica protagonista romana, Luke i Pepa, po europskim logorima tijekom Drugoga svjetskoga rata (Auschwitz, Jadwiga, Papinka, Norilsk, Krasnojarsk), a poglavlje Muke ро Рери (Josipu) donosi robijaške prizore s Gologa otoka.

U svojim dnevničkim i epistolarnim zapisima, koji u romanu slijede nakon spomenutih dionica tzv. literature svjedočenja, Luko, u metatekstualnome ključu, problematizira objavu i recepciju svojih logoraških zapisa, čime sedmodijelno Ropstvo po Luki funkcionira i kao intertekst samoga romana Uvod u tvrđavu.

„Pa sam, evo dvije godine po dolasku u Pariz, napisao knjigu o logorima u Auschwitzu i Jadwigi, koja uz ostalo ima i sjajan komercijalni uspjeh.

Takav uspjeh ne treba čuditi, jer do izlaska moje 'Kronike ropstva', širom Europe i svijeta tiskano je dosta knjiga s tom tematikom, ali kritika i publika u mojoj knjizi otkriva nešto posebno. Mislim da im se najviše dopada baš ta surova istina o životu u logorima...“(UUT: 176)

„Na sreću, već je izašla iz tiska moja knjiga 'Sibirski zapisi' koja postiže uspjeh i kod kritike i kod čitatelja. (...) Reakcije s Istoka su očekivano oštre, a i pariški komunisti dobili su sjajnu priliku da odbacivanjem moje knjige dokažu svoju pravovjernost.“ (UUT: 179)

„Početkom ovih sedamdesetih, zapadnoeuropsko i američko tržište nude milijunskom čitateljstvu bezbroj naslova knjiga u kojima se na razne načine opisuje i prikazuje sovjetski Gulag. Njihovi autori pripadaju raznim narodima, uglavnom istočne i srednje Europe, uključujući i Ruse. Većinom su to politički emigranti, često komunisti, koji su 
i po dva decenija odrobijali u Sibiru, donedavni funkcioneri u partijama i vladama, razne vrste otpadnika i razočaranih.“(UUT: 179)

„Prvo izdanje naše knjige već je rasprodano. Kritika je gotovo nepodijeljena u priznanjima i pohvalama. (...) Ali je zato naša i ostala emigrantska štampa povela protiv mene, kako ovdje kažu, nezapamćenu hajku.“(UUT: 221)

Lukini i Pepovi testimonijalni zapisi nose „stalna mjesta“ literature svjedočenja vezana za logorska iskustva. Zamjetan je prepoznatljiv logoraški leksik: kapo (logornik), esesovci, gestapovci, „,kupaonica/tuševi“, ,,preodgojeni“, „,sobni starješine“...

Logorsko ustrojstvo s hijerarhijskim osobitostima detaljno je predočeno, a velik broj epizoda posvećen je eksplicitnom iznošenju torture koju prolaze Pepo i Luko te ostali logoraši.

U predočavanju intimnoga svijeta žrtava logora simulacijom literature svjedočenja Šehović nije akcent stavio toliko na „osjećaj krivnje u preživjeloga kao locus classicus (klasično mjesto) literature o logorima“ (Agamben 2008: 62) koliko na problematizaciju ustaljene binarne opozicije dobro - zlo u kontekstu logoraškoga iskustva.

Riječ je o logoru kao nekom zasebnom univerzumu koji funkcionira „s onu stranu dobra i zla“ (naziv poglavlja u knjizi Prima Levija Zar je to čovjek) ${ }^{123}$, gdje granice između ove dvije moralne kategorije ne postoje više niti u fluidnim oblicima.

Ideja po kojoj bi zlo predstavljali mučitelji, a dobro logoraši kao njihove žrtve raspršuje se u fenomenu nazvanome „siva zona“ - poligonu za zorno propitivanje ljudskosti.

Naime, struktura logora bazirala se na mogućnostima da određeni logoraši poprimaju i sami povlašteni položaj te postaju logornici. Upravo scene u kojima logoraši na ovaj način sami muče jedni druge, gdje je očekivano subratstvo u zajedničkoj patnji zamijenjeno bešćutnim iživljavanjem nad onim do sebe, a sve u svrhu čistoga preživljavanja, donose kulminacijsku točku logorskih užasa.

Šehović je Luku kao protagonista romana postavio upravo u spomenuti položaj. Nedugo po dolasku u Auschwitz Luko se, zahvaljujući intelektualnome kapitalu i naglašenom nagonu za preživljavanjem, penje po logorskoj hijerarhiji i postaje kapo (logornik).

\footnotetext{
${ }^{123}$ Usp. npr.: „Htjeli bismo sada pozvati čitatelja da promisli što su u Lageru mogle značiti naše riječi 'dobro' i 'zlo', 'pravedno' i 'nepravedno'; neka svatko prosudi, na temelju slike koju smo skicirali te gore spomenutih primjera, koliko od našeg općeg moralnog svijeta može opstati s ovu stranu bodljikave žice.“ (Levi 2017: 94)
} 
Lukini introspektivni iskazi razotkrivaju neodrživost bilo kakvih moralnih isključivosti, posebice u logoru kao obliku tzv. „krajnje situacije ili graničnoga stanja“ (Agamben 2008: 34 $-35)$ :

„Neki nepojmljivi bijes potpuno nas obuzima i to što ga iskaljujemo na logorašima držimo sasvim prirodnim, jer bismo inače sami sebe izgrizli. Što sam više sam, sve više okrećem pogled u sebe.

Gledam kako brzo i temeljito ljudski osiromašujem, kako me uopće ne dira bol drugoga, kako zid ravnodušnosti oko mene postaje sve veći i čvršći, sve neprobojniji. To 'ovdje' postalo je dio nas i mi dio toga. Ovdje, kad čovjek griješi spram čovjeka, ne gubi samopoštovanje, ne grize ga savjest, još gore od svega, svejedno mu je. Ovdje su potpuno zaboravljena i odbačena tisućgodišnja pravila ljudskog ponašanja, čovjek se svojom sviješću vratio u prapočetak, u svoju daleku prethistoriju, u doba neshvatljiva divljaštva, kad mu je bilo samo do opstanka i kad je jeo druge oko sebe da ne bi sam bio pojeden.“(UUT: 18)

„Sebičan sam i samoživ do gađenja i što je najgore, svjestan sam te svoje izopačenosti. Ali, ne događa se to samo sa mnom. Bojim se da nitko u ovoj neljudskoj klimi ne može izbjeći tom sebičnjačkom sljepilu. I Pepo mi je priznao svoju ravnodušnost i otupjelost u ovoj 'umiraonici'. Postupao je kao i ja, kao svi, jer i sam priznaje da u životu postoje i takve okolnosti gdje je ljudskost nemoguća.“(UUT: 117)

Preživljavanje je u nacističkim i staljinističkim logorima i za Luku i za Pepa kao studente književnosti povezano s ,,povlaštenim statusom intelektualca, koji mu je upravo omogućio distancirano opažanje i pripovijedanje“ (Zlatar 2004: 172). Uz određene povoljne okolnosti, i intelektualni angažman omogućio im je da izbjegnu kategoriju onih „potopljenih“ u logoru i postanu „spašeni““. ${ }^{24}$

Kako je već ranije napomenuto ${ }^{125}$, i u logorima Šehovićevi likovi organiziraju stanovite književne seanse na kojima se, primjerice, raspravlja o poetici Dostojevskoga, recitiraju se

\footnotetext{
${ }^{124} \mathrm{O}$ potopljenima/spašenima u okviru iskustva logora vidi npr. poglavlje „Musliman“ u knjizi G. Agambena Ono što ostaje od Auschwitza (2008: 29 - 60), poglavlje „Utopljenici i spašeni“ u knjizi P. Levija Zar je to čovjek (2017: 95 - 110)...

${ }^{125}$ Vidi poglavlje ovoga rada vezano za svjedoke: „Odnos prema književnosti“.
} 
Puškinovi stihovi te stihovi iz Danteova Pakla. Referiranje na Pakao još je jedno od prepoznatljivih točaka tzv. literature svjedočenja. ${ }^{126}$

Na značaj intelektualnih svjedoka, posebno umjetnika, jasno je upozorio Geoffrey Hartman u jednome od svojih eseja istaknuvši kako „umjetnički intelekt, kombiniran s testimonijalnim imperativom, zauzima važnu ulogu u zahvaćanju i prenošenju traumatskoga iskustva“ (2006: 3). Hartman pri tome intelektualne svjedoke povezuje s kategorijom sekundarnoga svjedočenja, dakle svjedočenja onih koji nisu očevidci (eyewitnesses) već svoje svjedočenje baziraju na recepciji svjedočenja onih koji su nešto doživjeli na svojoj koži, vidjeli vlastitim očima, čuli vlastitim ušima...

U slučaju Šehovićevih likova Pepa i Luke razvidno je stapanje instance žrtve traumatskoga iskustva i intelektualnoga svjedočenja. Ovi likovi govore iz svoje pozicije patnika, progovarajući pri tom i za druge, za one ,potopljene“, koji predstavljaju nemogućnost svjedočenja.

Preživjeti da bi se pisalo i čitalo, postaje krilatica Lukina i Pepova opstanka u uvjetima raspada svih vidova humanosti:

„Kaže mi (Pepo) da u svemu ovome ima mnogo tragičnog i ponavlja da će o svemu tome napisati dramu, o kojoj mi je već govorio. Već je, kaže, ima u glavi, a naslov će joj biti 'Biblija za nevjernike'. U rijetkim slobodnim časovima sve češće mi govori o svojoj zamišljenoj 'Bibliji'. (...) Uostalom, u jedno sam nedvojbeno siguran, u oslobođenu pjesnikovu misao, i jedva čekam kada ću imati priliku da pročitam njegovu 'Bibliju za nevjernike'. Hoću li to zaista dočekati? Eto mi još jednog velikog razloga da preživim.“ (UUT: 116)

Luko apelira upravo na mogućnost Pepa kao književnika da umjetničkom riječju iskaže neiskazive užase:

\footnotetext{
${ }^{126}$ Npr. u Zar je to čovjek, u poglavlju „Pjesma o Odiseju“, Primo Levi, u maniri predanoga učitelja na školskome satu, nastoji francuskom studentu prevoditi Danteove stihove ukazujući mu na značaj Božanstvene komedije, razdijeljenost Pakla, simboliku Vergilija i Beatrice...

I apsurd i veličina istodobno proizlaze iz trenutaka kad se entuzijastično govori o umjetničkim pitanjima dok se obavljaju ponižavajući poslovi u logoru i čeka u redu na juhu od repe kao jedini obrok u danu.

Nastojeći se prisjetiti Danteova stiha, Levi sa sigurnošću izjavljuje:

„Dao bih današnju juhu kad bih znao spojiti 'takve jošte ne vidjeh' sa završetkom. Naprežem se ne bih li uz pomoć rime rekonstruirao stihove... (...) 'i krmu digne, kako drugom godi' (...) Zadržavam pikola, neophodno je potrebno i neizostavno da sluša, da shvati ovo 'kako drugom godi', prije nego što bude prekasno, on ili ja sutra možemo biti mrtvi...“(2017: 128)
} 
„Govorim koješta, pa i to da je pisac, možda jedini u ovoj masi nevinih stradalnika, koji je jedini u stanju sve ovo vidjeti i osjetiti na pravi način. - S tim se svijet mora upoznati - gorljivo propovijedam.“(UUT: 111)

Ovakva konstelacija umjetnika i traume (u smislu njezina zahvaćanja umjetničkom formom) korespondentna je s pitanjem pisanja o traumatskim iskustvima u djelu Pisanje ili život, gdje autor Jorge Semprun pred čitatelja donosi potresnu ispovijest o stradanjima u Buchenwaldu.

Semprun napominje kako nakon iskustva logora ,izazov neće biti opisivanje užasa, (...), izazov će biti promatranje ljudske duše u užasu Zla...Trebat će nam novi Dostojevski!“ (1996: 114) Smatra da je potrebno jedno narativno ,ja“ koje će se hraniti iskustvom, ali će na to iskustvo nadograditi ono imaginarno, ,fikciju koja bi pomogla stvarnosti da izgleda stvarno, a istini da bude vjerodostojna“" (147).

Dakle, suštinsku istinu o nezamislivim užasima ne može doseći nikakva povijesna rekonstrukcija jer autentična se, doživljena istina može prenijeti samo putem književnoga izraza, tvrdi Semprun (112 - 113).

U svjetlu prethodno iznesenoga, može se zaključiti kako Šehović karakterizaciju svojih protagonista Luke i Pepa velikim dijelom temelji upravo na ideji povlaštenoga statusa umjetnika kao svjedoka logorskih (i drugih) trauma, na aktivističkoj misiji umjetnika kao nekoga tko svoj umjetnički diskurs može (i mora) postaviti u suodnos s onim službenim historiografskim.

\subsubsection{Poetski tekstovi}

Kako je već ranije napomenuto ${ }^{127}$, svaki od romana tzv. dubrovačke trilogije u okviru testimonijalne dokumentacije sadrži poetski tekst paracitatnoga karaktera: Vickova zbirka od 25 pjesama u Gorkom okusu duše, poema Oslobađanje đavola u Oslobađanju đavola:

Kronika, drama Tvrđava: Biblija za nevjernike te dvije poslanice u romanu Uvod u tvrđavu: Biblija za nevjernike.

\footnotetext{
${ }^{127}$ Vidi potpoglavlje ovoga rada „Odnos prema književnosti“ u „Svojstva likova svjedoka i njihova naratološka izgradnja“.
} 
Značaj tih tekstova u kontekstu trilogije ogleda se, među ostalim, i u činjenici što romani svoje naslove duguju upravo spomenutim poetskim tekstovima (u Oslobađanju đavola i Uvodu u tvrđavu to je izravno vidljivo, dok je Gorak okus duše dobio naziv prema stihu iz zbirke pjesama unutar romana).

Fiktivna zbirka od 25 pjesama svećenika Vicka iz Gorkoga okusa duše dodana je kao posljednje poglavlje romana, što je naznačeno fusnotom:

„Sve ove pjesme nastale su u posljednjem desetljeću Vickova života, a tiskane su u slobodnom prijevodu s latinskog. U nedostatku naslova, označene su rimskim brojevima od I - XXV, a pisac romana ih je dodao kao posljednju (IX) glavu.“ (GOD: 146)

Zbirka funkcionira kao iskaz svjedoka traumatičnih događaja o kojima se govori u narativnome dijelu romana. Time joj je dodijeljena uloga ovjeravatelja u autentičnost prethodno iznesenoga, zbog čega se može reći kako u ovom slučaju jedan fiktivni tekst pridonosi istinitosti drugoga fiktivnoga teksta (fakcionalizacija fikcije).

U daljnjem će potpoglavlju ovoga rada pjesnička zbirka iz Gorkoga okusa duše poslužiti kao primjer intertekstualnosti dokumenata svjedočenja (kako u okvirima samoga romana, tako i izvan njegovih okvira - u odnosu prema tekstovima književne baštine).

Za razliku od poetskoga svjedočanstva u Gorkome okusu duše, poema Oslobađanje đavola iz istoimenoga romana nije ugrađena u tekst romana, već se na nju samo poziva od strane ekstradijegetičkoga-heterodijegetičkoga pripovjedača u određenim narativnim segmentima.

Poema predstavlja fra Mavrovu poetsku reakciju na razorni potres koji je zahvatio Dubrovnik 6. travnja 1667. godine, kao i na političku pozornicu Dubrovnika toga vremena. Vickova zbirka pjesama i fra Mavrova poema dijele u okviru tematsko-idejne razine ovih romana istu sudbinu: demonstriraju već ranije spomenut Foucaultov pristup diskursima kao objektima apropriacije, što dovodi i do kaznene apropriacije (don Vicko i fra Mavro završavaju u istražnim zatvorima), čime se poetsko djelovanje uvijek realizira kao ,gesta nabijena rizicima“" (v. Foucault 2015a: 47 - 48).

Fiktivna Pepova drama Tvrđava: Biblija za nevjernike iz romana Uvod u tvrđavu također nije inkorporirana u tkivo romana već funkcionira na razini provodne reference. 
Drama je nastala kao odgovor na Pepove i Lukine patnje pretrpljene u europskim logorima tijekom Drugoga svjetskog rata.

Pepo kao autor drame ne doživljava kazneni progon poput gore spomenutih likova svećenika, ali drama biva izvrgnuta snažnoj ideološkoj kritici, čime se i ovaj put ostvaruje suodnos poetskoga i ideološkoga kao stalno mjesto Šehovićeve novopovijesne trilogije. Kao paracitatni zapisi ugrađeni u roman Uvod u tvrđavu djeluju i dvije Pepove poslanice: Josipova (Pepova) poslanica prijatelju L. B. te Poslanica prijatelju piscu.

Poslanica prijatelju Luki Božidareviću funkcionira kao svojevrstan predgovor romanu, a sadrži idejnu težišnicu ne samo ovoga romana nego i svih Šehovićevih romana koji problematiziraju odnos pojedinca i povijesti - riječ je o zastupanju pozicije ideološkoga nevjernika kao jedinog prihvatljivog svjetonazora, o sumnji kao zajedničkom nazivniku svakog pokušaja ideološke interpretacije povijesnih gibanja:

„(...) Tebi, što se nisi uprezao u kola / velikih ideja, s uzdom među / vilicama i konjskim kapcima na / očima, da ne bi vidio ništa više osim / puta kojim te vode. Tebi poganine, što prezireš ovo / stoljeće poludjelo od vjera i zločina, / što u našim oceanima smisla vidiš / samo plićake besmisla i nikad ne / gubeći vezu sa životom uvijek / načisto s onim što nećeš. (...)

Tebi, dosljedni bezvjerče. (...)“(UUT: 5)

Poslanica prijatelju piscu (UUT: 90 - 92), u kojoj već iskusni autor mladim piscima donosi niz uputa o kreaciji književnoga djela, intertekstualno se oslanja na jedan od modela hrvatske renesansne poslanice, posebno u okviru književnosti dubrovačkoga kruga. Dunja Fališevac napominje kako su metatekstualni zapisi i književnokritičke te poetske refleksije mnogo bogatije u proznim nego u stihovanim hrvatskim renesansnim poslanicama (2008: 7 - 25). Stoga ova fiktivna Pepova poslanica svojom formom i sadržajem stupa u dijaloški odnos s onim manjim brojem stihovanih hrvatskih renesansnih poslanica metapoetske prirode.

Bez obzira na različite formalne i sadržajne karakteristike te način inkorporacije $u$ tekst romana kojem pripadaju, svi navedeni paracitatni poetski zapisi odražavaju pretvorbu traumatskoga iskustva svjedoka-pjesnika u umjetnički čin, a time i odgovornost pjesničke ličnosti da putem poetskoga diskursa svjedoči istinu svoga vremena. 


\subsubsection{Esejističke bilješke}

Dok je u povijesnim romanima iz osamdesetih godina 20. stoljeća (Gorak okus duše, Oslobađanje đavola: Kronika i Uvod u tvrđavu: Biblija za nevjernike) Feđa Šehović bio usmjeren na područje Dubrovnika, u romanima objavljenima u 21. stoljeću (Ilijasbegovići: Cronica travuniana i Prokleta ergela) tematsko-idejno zahvaća Bosnu i bošnjaštvo.

S obzirom da će svjedočenje u službi tvorbe identiteta zajednice posredstvom autopredodžbi i heteropredodžbi (imagološka perspektiva) biti problematizirano u šestome poglavlju doktorskoga rada, ovom će se prilikom na tu problematiku tek okvirno ukazati u kontekstu diskurzivne klasifikacije dokumenata svjedočenja u Šehovićevim povijesnim romanima. Naime, dokumenti koji bi se u Ilijasbegovićima mogli diskurzivno svrstati pod esejističke zabilješke svjedoka tematsko-idejno vezani su za predodžbe o Bosni i bosanskom/bošnjačkom identitetu.

Budući da heterogenost kao jedno od temeljnih svojstava eseja odvodi do nemogućnosti jasnog definiranja granica žanra (Oblučar 2014: 75), eseju će se u ovome potpoglavlju prići na definicijski najširoj odrednici ovoga žanra - kao tekstu koji se prilikom svoje usredotočenosti na neko životno ili spoznajno pitanje koristi kombinacijom elemenata znanstvenoga i književnoga stila (Solar 2006: 91).

Iako je esej u principu obilježen fragmentarnošću i relativnom kratkoćom (isto: 91), dokumenti iz Šehovićevih romana promatrat će se u okviru esejističkoga diskursa, usprkos njihovoj monografskoj prirodi u formi cjelovite knjige, temeljem gore spomenute stilske simbioze znanstvenog i književnog promišljanja o relevantnim i aktualnim pitanjima ${ }^{128}$.

Drugi roman ciklusa o Ilijasbegovićima (Inšallah) protagonista Hasan-bega postavlja u poziciju svjedoka preko esejističkih zabilježaka koje je kao ratni zarobljenik napisao u formi osvrta na knjigu gospara Antuna, „u kojoj se veličaju ideje i pobjede Eugena Savojskog o vraćanju Bosne ognjem i mačem u krilo katoličanstva“ (I: 232).

\footnotetext{
${ }^{128}$ Sljedeći navodi mogu potvrditi znanstveno-umjetničku stilsku osobitost esejističkih zabilježaka iz Šehovićevih Ilijasbegovića (esejističke bilješke u romanu direktno su predočene putem navoda integriranih u tekst romana ili prepričane od strane ekstradijegetičkoga pripovjedača):

„Tako je tu oduvijek, u našoj zemlji Bosni - strepnja za sutra. Zašto? Dokle to pitanje? Zašto susjedi drugih vjera toliko žele da nas unište ili protjeraju s ovih prostora? Muslimani smo drage volje budući da se našim pradjedovima islam učinio bliži i prihvatljiviji, a možda i skloniji čovjeku od stare vjere.“ (I: 312)

„Kako su neprijatelji naše Bosne uspjeli čak i mnoge franjevce upregnuti u svoju rušilačku namjeru? Ne šalju više u Bosnu prinčeve Savojske, već nebošnjačke biskupe i provincijale što ne siju u narodu Kristovo sjeme ljubavi, već mržnje koje kao i svako zlosjeme neće dugo čekati da proklija.“ (I: 479)
} 
Begovina, treći roman Ilijasbegovića, donosi čak dva primjera esejističkoga promišljanja „bošnjačkoga pitanja“.

Između ostaloga, o interkonfesionalnim vezama na prostoru Bosne progovara fra Ivan Lovrenović (prijatelj i svjedok Ilijas-bega kao protagonista Begovine) u svojoj knjizi Muslimani i bosanski franjevci.

Enver-beg, Ilijas-begov sin, poziciju bošnjačkih muslimana u kontekstu suvremene Europe preispituje zapisima Ko smo to mi muslimani и BiH.

Posljednji dio ciklusa o Ilijasbegovićima (Od Mostara do Den Haaga) aktualizira gore naznačenu problematiku preko zapisa Ilijasova rođaka Rusa, kojima se nastoji pokazati kako je „bošnjački narod (muslimani), od svojega postanka do dana današnjega i tko zna do kada još, izložen neprestanom nasilju zbog brisanja njegove vjere i imena““ (I: 800).

Svi gore navedeni primjeri esejističkih zapisa pokazuju usmjerenost na pitanje koje se tijekom povijesti pojedinim članovima obitelji Ilijasbegović nametnulo kao aktualno i od sudbinske važnosti, kako na individualnoj, tako i na kolektivnoj razini - pitanje položaja Bošnjaka-muslimana ${ }^{129}$ u Bosni i Europi.

Upravo vezanost za aktualno i za svakidašnjicu esej približava diskursu dnevnika i kronike, a esejista postavlja u poziciju javnoga svjedoka kao bilježnika događaja (Glaude i Louette 2011 prema Oblučar 2014: 78).

Okrenutost eseja spoznajnom $\mathrm{i}$ istinitom na drugačiji način od poetičkih tekstova, njegov ,zahtjev za istinom bez estetičkoga privida“ (Adorno 1985 prema: Oblučar 2014: 76) demonstrirana je u segmentu Šehovićeve Begovine, gdje Ilijas-beg povodom izlaska Enverbegove knjige o Bošnjacima-muslimanima naglašava opasnost esejističkoga pisanja u odnosu prema književnome pisanju (u užem smislu):

„Sine moj, nije ovo što i tvoji komadi u kazalištu; nasmiješ se ili zaplačeš, pa nikome ništa. U njima govoriš o sudbinama izmišljenih ljudi, a u knjizi o živima. Od zabluda u komadima nitko neće stradati, ali u životu često zbog njih strada cijeli narod.“(I: 475)

Ovakav navod u kontradikciji je s primjerima iz nekih Šehovićevih romana, gdje svjedociprotagonisti stradavaju, između ostaloga, i zbog svoga poetskoga djelovanja (don Vicko iz Gorkoga okusa duše i fra Mavro iz Oslobađanja đavola). Zapravo, svako pisanje koje nije u

\footnotetext{
129 „Bošnjaci-muslimani“ sintagma je korištena u samom romanesknom ciklusu Ilijasbegovići, ponegdje upotrijebljena i u pridjevnome obliku „bošnjački muslimani“.
} 
službi vladajućih ideoloških mehanizama u Šehovićevim se romanima prezentira kao potencijalno opasno polje društvenoga djelovanja.

$\mathrm{Na}$ kraju ovoga potpoglavlja valja se osvrnuti na status esejističke istine, te $\mathrm{s}$ tim $\mathrm{u}$ vezi i na učinke odabira esejističkih bilježaka kao oblika testimonijalne dokumentacije u Šehovićevim Ilijasbegovićima.

Naime, francuski teoretičari Pierre Glaudes i Jean-Francois Louette spoznajni status eseja dovode u vezu sa sintagmom „kondicionalna istina“ (analogno Genettovoj „kondicionalnoj fikciji““); riječ je o svjesnosti eseja da je istina uvjetna, dakle parcijalna i subjektivna, što uključuje mogućnost promjene perspektive, na što aludira i etimologija žanra - pokušaj, proba, odvagivanje ( prema Oblučar 2014: 82).

Upravo ovakav spoznajni predznak esejističkoga diskursa doprinosi efektu subjektivnosti, dakle intimnosti misli u zapisima svjedoka unutar Ilijasbegovića, čak i u slučaju govora o „velikim“ temama - kakvo je pitanje statusa Bosne i bošnjačkoga/bosanskoga identiteta.

\subsubsection{Usmeno kazivanje}

Za razliku od tradicionalnoga povijesnog romana šenoinskog tipa, u hrvatskome novopovijesnom romanu težinu ,pravoga“ dokumenta nerijetko nosi i ,usmeni iskaz slabog svjedoka (Nedjeljko Fabrio, Ivan Supek, Ivica Ivanac)“ (Matanović 2003: 148).

Usmeno kazivanje u funkciji svjedočenja povijesno beznačajnoga pojedinca o sudbini onih povijesno značajnih svoju reprezentativnost postiže u romanu Ivice Ivanca $U$ službi Josipa baruna Jelačića(1990.) ${ }^{130}$, kojem u podnaslovu stoji „kazivanje“. Naime, čitav je roman strukturiran kao kazivanje priprostog Jure Škrleca, koji je jedno vrijeme bio „posilni“ baruna Jelačića, stoga mu je ,,pravo na govor osigurala bliskost s osobom koja je kreirala važnu dionicu službene hrvatske povijesti““ (Nemec 2003: 292).

Već na samome početku romana Škrlec ističe da progovara iz pozicije povijesnoga „,autsajdera“ budući da „nije od poznate obitelji Škrlec, koja već spada u povijest Hrvata“ (Ivanac 1990: 7), pri čemu je svjestan „,raskoraka 'snage' diskursa povijesti i vlastite 'autorske' inferiornosti““ (Nemec 2003: 293).

\footnotetext{
${ }^{130}$ Ovaj je roman izlazio u nastavcima u Večernjem listu 1970. godine. (Nemec 2003: 292)
} 
Kazivač Škrlec direktno se obraća čitatelju/slušatelju izrazom „gospodine moj mladi“, te uz kontinuirano pijuckanje vina kao da „ćaska“ sa sugovornikom:

„Vjerujete li vi to meni?““(Ivanac 1990: 9); „Jako ovo vino, ha?“ (isto: 22); „A, vi to već znate? Onda tim bolje.“ (isto: 29); „Jeste li još za čašicu? Prirodno je, bez brige, sam ga pijem.“ (isto: 32 ); „Što sam ono htio reći?“ (isto: 47); „Gdje smo ono stali? Aha!Vidite..." (isto: 179)...

Dakle, u slučaju Ivančeva romana vidljiv je „model usmene komunikacije“ pa slušatelj ima dojam da je fizički uključen u priču, zbog čega kazivača može prekidati, usmjeravati, sumnjati u izneseno, intervenirati... ( Matanović 2003: 143)

Mada se Feđa Šehović kao pisac povijesnih romana u pravilu poziva na zapis, a ne na usmeni iskaz, oralno svjedočenje dolazi do izražaja u njegovim romanima Uvod u tvrđavu te $\mathrm{u}$ dijelu Ilijasbegovića (Inšallah). ${ }^{131}$

U Uvodu u tvrđavu Lukini i Pepovi testimonijalni zapisi o logoraškim danima kombinirani su izmjenično s dijelovima koji nose naslov Govorenje svjedoka. U tim poglavljima, po modelu ,govorenja“ (kako to i naslov sugerira), čitav niz svjedoka donosi pojedinosti o vremenu prije Lukinih i Pepovih logorskih iskustava, čime Lukin i Pepov curriculum vitae zadobiva efekt upotpunjenosti i zaokruženosti.

Kako je već ranije napomenuto, imena svjedoka govornika nisu naznačena, kao ni priroda njihova odnosa s protagonistima, zbog čega je pred čitatelja stavljen određen napor/izazov pri identifikaciji glasa koji govori.

Tako, primjerice, jedan dubrovački urar svjedoči o pritvaranju Pepa i Luke zbog tuče (UUT: 65); radnik u tvrtki Lukina oca Andre Božidarevića iznosi događaje s Lukina i Pepova maturalnoga plesa; glavni tajnik u kompaniji Lukina oca (66), sekretar gradskog komiteta Saveza komunističke omladine (69) i prijatelj Pepova oca Raula Mitrovicha (71) svojim iskazima upućuju na Pepova i Lukina ideološka i politička djelovanja te oprečnost u njihovim stavovima; neki svjedoci iznose značajna zbivanja u studentskom, političkom i ljubavnom životu protagonista $(89,92,103$ - 105...); urednik književnoga časopisa komentira odjek Pepove poslanice „Nevjernik“ (90); o Pepovu sudjelovanju u Španjolskom građanskom ratu svjedoči njegov suborac (105) itd.

\footnotetext{
${ }^{131}$ Pozivanje na usmene iskaze u manjoj je mjeri i sporadično vidljivo i u drugim Šehovićevim povijesnim romanima.
} 
Zanimljivo je spomenuti da su u Uvodu u tvrđavu (u odnosu na prva dva romana trilogije) uvedene i svjedokinje, dakle i ženski glasovi (Pepova teta Perica, Pepova i Lukina poznanica Milena, Lukina sestra Mada), što pridonosi raznolikosti testimonijalnoga govora. Iskazi svjedoka u ovom Šehovićevu romanu tek su jednim svojim segmentom obilježeni govornom karakterizacijom. Govorne se osobitosti, naime, očituju tek u uporabi ekavice pri kazivanju svjedoka srpske nacionalnosti - riječ je o Danilu, novinaru s kojim je Luko u Beogradu pokrenuo književni časopis na francuskome jeziku te o Danilovoj rođakinji Mileni.

U Inšallahu, drugom romanu ciklusa o Ilijasbegovićima, sudbina protagonista Hasanbega predočena je kombinacijom zapisa njegove žene Sultanije i usmenoga kazivanja najboljega prijatelja Enesa. Dok Sultanija donosi informacije vezane uz prostor intime doma, Enes-beg kao Hasan-begov najbliži prijatelj i osoba od najvećeg povjerena „začinja“ priču o Hasan-begovu životu pojedinostima vezanima za njegovu ljubavnicu Lejlu, ali i kao Hasanbegov suborac (vrijeme Eugena Savojskoga po Bosni) Enes pripovjedački oblikuje njihove ratničke podvige.

Razlog Enesovu usmenom, a ne pisanome svjedočenju leži u činjenici da nije baš tečno čitao ni pisao, ali je znao vješto pripovijedati. Kao strastveni svirač na sazu (stara bosanska tambura slična gitari) i blagoglagoljiv kazivač priča, Enes utjelovljuje koncept tradicionalnoga usmenog pripovjedača. O Enesovu urođenome talentu za priču pripovjedač najčešće izvještava posredstvom Sultanijinih komentara iz njezinih Zapisa:

„Oduvijek ju je oduševljavao Enesov neobičan i sočan način pričanja jer u njegovu pričanju jednostavni jezik odjednom postaje bogat i osebujan, krcat pronicljivih zapažanja. Njegovo pričanje uvijek je nekako ljepše od onoga što se dogodilo, ne zato što izbjegava ružno u životu, već naprotiv po njegovoj hrabrosti da kaže istinu i ljepoti kojom to radi. U Enesu je davno otkrila rođenog pripovjedača i ona ne krije da mu na tome zavidi.“ (I: 280 - 281)

Kao što se Sultanija u svojim Zapisima redovito referira na Enesovo usmeno kazivanje (npr. interpolira u svoje pripovijedanje neke Enesove priče), i Enes povremeno citira rečenice iz Sultanijinih zapisa, slijedom čega usmeno i pisano kazivanje ostvaruju određenu vrstu intertekstualnih odnosa.

Kako je već ranije kazano, usmeno kazivanje kod Šehovića nerijetko stupa u interaktivan odnos s pisanim kazivanjem preko imperativa zapisivanja. Tako su mnogi likovi 
na Šehovićevoj romanesknoj povijesnoj pozornici stavljeni u ulogu zapisivača nečijih izgovorenih riječi ${ }^{132}$. Vidljiv je takav model „govorenja u pero“ u Gorkom okusu duše (don Vicko bilježi fra Vincencovo predsmrtno kazivanje o vlastitome životu), a posebno u Ilijasbegovićima, gdje početak i kraj ove obiteljske sage obilježava upravo molba „zapiši“, upućena od strane umirućeg „sužnja“ svome svjedoku (fra Matija zapisuje riječi Ilijas-bega, a fra Petar Enkove).

Na ovaj je način Šehović u svojim povijesnim romanima istaknuo motiv privilegiranosti i odgovornosti zapisivanja tuđih riječi preko pozicije svjedoka, kao i dinamiku suodnosa usmenoga i pisanoga iskaza.

\subsubsection{Slikovni zapis}

Osim kao verbalni akt (pisani ili usmeni), dokument se, kao modus svjedočenja, u hrvatskome novopovijesnom romanu javlja i u slikovnome obliku - kao slika, fotografija i sl. $^{133}$

Dok neki autori povijesnih romana, u tom kontekstu, preko motiva portreta velikih, znamenitih ljudi otvaraju pitanje njihove (ne)očekivane/(ne)željene povijesne prezentacije (npr. portret biskupa Strossmayera u Zlatoustome Stjepana Tomaša ili portret bana Jelačića u romanu U službi Josipa baruna Jelačića Ivice Ivanca) ${ }^{134}$, Feđa Šehović i Nedjeljko Fabrio, među ostalima, naglasak stavljaju na portrete neznanih povijesnih „,(anti)junaka“, najčešće preko obiteljskih slika/fotografija.

Tako „u vizualnom, koje se temelji na fragmentarnim ostacima kao što su fotografije, počiva sjećanje jedne obitelji“ (Hirsch 1997: 127 prema Belaj 2008: 145); fotografijama „svaka

\footnotetext{
${ }^{132}$ Ovakvu simbiozu izgovorene i zapisivane riječi demonstrira i roman Ivana Supeka Buna Janusa Pannoniusa (1992.), gdje klesar Miroslav kao „sačinjavalac“ neke vrste oporuke pjesnika i buntovnika Janusa Pannoniusa ističe u predgovornoj napomeni kako je zapise sročio kombinacijom Panonniusovih bilješki i predsmrtnoga kazivanja.

${ }^{133}$ Iako se nerijetko radi razlika između slike i fotografije s obzirom na njihov odnos prema stvarnosti (u smislu efekta realističnosti, vjerodostojnosti i ,istinitosti“), Susan Sontag smatra kako su „fotografije u jednakoj mjeri tumačenje svijeta koliko su to ulja na platnu i crteži“" (2007: 14).

${ }^{134} \mathrm{Npr}$. u Zlatoustome S. Tomaša otac Rufin komentira pripovjedaču kako biskup Strossmayer nikad nije bio zadovoljan svojim portretima smatrajući kako nikad nije prikazan u pravome svjetlu. Isto tako, u Ivančevu romanu U službi Josipa baruna Jelačića, Jelačiću nije svejedno kako će ga povijest „,naslikati“:

„Sjedi u naslonjaču duboko zamišljen, pa zato on sam nikad nije volio tu sliku jer je on bio vojnik, ban Hrvata. Više je volio one slike na kojima su ga slikali na konju.“ (1990: 12)
} 
obitelj gradi vlastitu portretnu kroniku - prijenosnu kolekciju prizora koja svjedoči o njezinoj povezanosti““ (Sontag 2007: 15).

Slike/fotografije kojima se koristi Šehović (kao i ostali pisci hrvatskih novopovijesnih romana) u svojim romanima, prema kategorizaciji Marianne Hirsch, pripadaju tzv. fiktivnim ili proznim slikama, budući da je riječ o slikama koje nisu umetnute u strukturu romana već funkcioniraju na razini opisa (v. Belaj 2008: 139).

Ovom prilikom valja podsjetiti na napomenu Rolanda Barthesa kako se pripovjedni tekst javlja, od samog početka čovječanstva, u gotovo beskonačnim oblicima: kao artikulirana jezična djelatnost (usmena ili pisana), kao čvrsta ili pokretna slika, pokret, ili pak mješavina navedenoga (v. 1992: 47). Slijedom toga, i slika/fotografija funkcionira kao narativna struktura. Narativni kontekst fotografije ističe, primjerice, i Victor Burgin koristeći se sintagmom „fotografski diskurs“, ili pak, Marianne Hirsch izrazom „slika-tekst““ (v. Belaj 2008: 139).

Osim što, slijedom prethodno rečenoga, slike/fotografije same po sebi predstavljaju narativnu formu, one i potiču pripovijedanje jer ,na neki način vezuju i zajednička sjećanja koja se uvijek iznova pričaju dok se fotografije gledaju“ (Belaj 2008: 144). Na koji način obiteljska fotografija može predstavljati „okidač“ za priču o prošlosti pojedinca/obitelji te održavanje sjećanja iscrpno pokazuje Fabrijev pripovjedač /,povjerenik za priču“" u Berenikinoj kosi kad na punih 15 stranica na temelju skupne fotografije snimljene 1906. godine na dan vjenčanja Filipa Gorme razotkriva biografiju svakoga lika s te fotografije (izneseno 13 ,biografie alla croata“") ${ }^{135}$.

Slično postupa Feđa Šehović u 34. poglavlju Begovine (treći roman ciklusa Ilijasbegovići), ali u puno manjem obimu nego Fabrio. Na poticaj maloga Ilijasa kao protagonista završnoga dijela Begovine, baka Almasa pričala je o prošlosti Ilijasbegovića:

„Bile su to pripovijesti o uljanim slikama naših davnih predaka, koje su visjele u najvećoj i najljepšoj prostoriji Begovine, što smo je u obitelji još uvijek zvali divanhanom, a ponekad salonom ili vizitnom sobom.“ (I: 461)

${ }^{135}$ V. Fabrio (1990: 258 - 274) 
U slučaju uljanih slika Ilijasbegovića značajno je zamijetiti ono što je već spomenuto u jednom od početnih poglavlja ovoga rada ${ }^{136}$ : identični prikazi gubitničkoga položaja tijela članova obitelji Ilijasbegović ukazuju na fenomen povijesne ponovljivosti:

„Najstarija slika je ona miralaja Hasan-bega s početka 18. stoljeća, koju je naslikao neki značajni hrvatski slikar. Lijep, sredovječan turski časnik sjedi na nečemu u nekoj sobi s laktovima na koljenima i prstima zarivenima u kosu, tako presamićen poput kipa beznađa. (...)

Druga uljana slika, također s bogatim pozlaćenim baroknim okvirom, budila je u meni još veću znatiželju, ne zato što je u pozadini lika naslikano Sarajevo u dimu i vatri kada ga je osvojila austrijska vojska, nego zbog neke očite sličnosti lica s obje slike koju mi ni'ko u kući nije mogao objasniti na zadovoljavajući način. Najprije, na jednom i drugom portretu kao da je bila ista osoba, nevjerojatno slična lica, a onda to što me najviše zbunjivalo bio je gotovo potpuno istovjetan položaj tijela jednog $i$ drugog: laktovi zariveni u koljena, a prsti u kosu. “ (461 - 462, dijelove istaknula D. M. L.)

Ovakav odnos prema povijesti preko slikovne forme zamjetan je i kod već spomenutoga N. Fabrija, u Triemeronu - trećem romanu tzv. Jadranske trilogije (usp. Matanović 2003: 164 166).

Prema Matanović, pripovjedač, metodom ponavljanja, na dva mjesta u romanu ${ }^{137}$ donosi opis „dviju fotografija iz obiteljskoga albuma snimljenih pred političku oluju“: jedna fotografija odnosi se na kolovoz 1939. godine u Splitu, druga na ožujak 1971. godine u Zagrebu, ali obje donose gotovo isti prizor, opisan gotovo istim rečenicama.

Riječ je o demonstracijama u kojima su u oba slučaja sudjelovali djed, sin i unuk: na prvoj fotografiji riječ je o Menegu, Ivanu i Eciju, a na drugoj o Ivanu, Eciju i Andreju. Bez obzira na raspon od 32 godine, te dvije fotografije kao da pokazuju isto, ukazujući na repetitivnost povijesnih situacija.

Dok je preko gore opisanih uljanih slika (još jednom) podsjetio na cikličnu formu povijesti, Šehoviću je motiv obiteljskog albuma u već spomenutome 34. poglavlju Begovine poslužio za ocrtavanje još jednoga vida odnosa prema povijesnome.

\footnotetext{
136 „Povijesni romani Feđe Šehovića u kontekstu hrvatskoga povijesnog romana“

${ }^{137}$ Vidi: Fabrio (2002: 151 - 153, 260 - 261)
} 
Taj debeli kožnati album, koji je fotografijama zahvaćao sva važnija zbivanja, ,zaista je pregledna povijest i kronika obitelji Ilijasbegovića u Begovini od početka stoljeća“" (I: 464) (misli se na 20. st.).

Značajno je da su fotografijama u albumu zastupljeni svi članovi obitelji, čak i ,otpadnici“ (poput Refike, koja se zaljubila u ideološki sumnjivog pjevača Arifa).

Na ovaj način, preko slike „cjelovitoga“ obiteljskoga albuma, Šehović nudi ideju povijesti koja bi prema prošlosti, umjesto redukcionizma i isključivosti, razvijala intenciju poliperspektivnosti i uključivosti. 


\subsection{Inkorporacija dokumenata u romanesknu strukturu}

\subsubsection{Predgovorne bilješke}

U naratološkim okvirima predgovori, kao i naslovi djela, naslovi poglavlja, posvete, epigrafi i bilješke (itd.), za francuskoga književnog teoretičara Gérarda Genettea predstavljaju paratekstualne tvorbe stoga što ,ne znamo uvijek trebamo li te kreacije promatrati kao pripadne tekstu“ (Genette prema Grdešić 2015: 111). Naime, paratekst funkcionira kao „prag“, „,nedefinirana zona“ između onoga unutar i onoga izvan teksta, zona bez čvrste i jasne granice kako s unutarnje (tekstualne) strane, tako i s izvanjske strane (diskurz o tekstu) (prema Grdešić: isto).

Predgovori (u romanima) kao paratekstualni segmenti pripadaju skupini periteksta jer se nalaze u sklopu djela ${ }^{138}$, a najčešće predstavljaju ona mjesta u kojima autor prezentira i/ili komentira svoje djelo (Genette prema Buljubašić 2017: 32), stoga su nerijetko obilježena (i) autoreferencijalnim nabojem.

Cilj je ovoga potpoglavlja ukazati na značajke predgovornih bilježaka u Šehovićevu romanu Gorak okus duše, kako u kontekstu hrvatskoga novopovijesnog romana, tako i u relaciji prema tradicionalnome povijesnom romanu.

Gorak okus duše jedini je Šehovićev povijesni roman koji u svome sastavu sadrži predgovor. S obzirom da je riječ o predgovoru (naslovljenome upravo kao Predgovor) čiji je tvorac navodni autor (potpisan na kraju predgovora kao Autor), a koji ustvari predstavlja fiktivnu kreaciju povezanu s konvencijom pronađenoga zapisa, u ovome slučaju riječ je o Genettovom terminologijom - autografskome i fiktivnome predgovoru (Genette prema Buljubašić 2017: 32).

Šehovićev fiktivni autor predgovora postavljen je u poziciju pronalazača rukopisa te sastavljača teksta načinjenoga na temelju pronađene građe.

Kad je riječ o književnim djelima koja se oslanjaju na konvenciju pronađenih rukopisa, „,većina takvih tekstova u povijesti književnosti ima duži i kraći narativni okvir u kojem njihov nalaznik ili 'urednik' objašnjava čitateljima kako je došao do tih zapisa i zašto ih je odlučio objaviti“ (Grdešić 2015: 104).

\footnotetext{
${ }^{138}$ Gérard Genette paratekst dijeli u dvije skupine: epitekst, koji se odnosi na elemente izvan samoga djela (npr. intervjui s autorom, kritike djela...) i peritekst, koji uključuje elemente u samome djelu (naslovi poglavlja, predgovori, bilješke...). (v. Grdešić 2015: 111)
} 
U okviru hrvatskoga novopovijesnog romana spomenuti je narativni okvir, primjerice, reprezentativan u predgovorima romana Ivana Katušića Admiralski stijeg („Urednička uvodna napomena“) i Lea Držića Magarcima pucaju rebra („Umjesto uvoda“).

U oba predgovora navedenih romana prisutan je ,glas“ urednika koji je igrom slučaja došao do rukopisa kojima je prijetila opasnost od uništenja.

Katušićev „urednik“ spasio je od požara u potkrovlju jedne zgrade sudske spise Maksimilijana Lantine o istrazi protiv Vicka Viribusa, osumnjičenoga da je izdajnički surađivao s talijanskim časnicima prilikom potapanja austrijskog admiralskog broda u pulskoj luci 1.11.1918. godine.

I urednički glas u predgovoru Držićeva romana do gradske kronike pisara Dominika Pivarića dolazi slučajno, a spašava ih od neminovnoga gubitka, pri čemu navodi put kojim su rukopisi stigli u njegove ruke: Franjo Venčec pronašao ih je na tavanu svoje kuće među pljesnivim knjigama i papirima koji su trebali poslužiti za potpalu; Venčecov sin rukopise prodaje jednome kestenjaru da bi došao do novca za kino-ulaznicu; urednik predgovora nailazi na rukopise kod kestenjara i pokušava srediti njegove požutjele listove ${ }^{139}$.

Nakon objašnjenja kako su došli do rukopisa, oba urednika u nastavku „objavljuju“ spomenute rukopise.

Gorak okus duše svojim se predgovorom tek djelomično uklapa u upravo opisanu paradigmu. Naime, tvorac predgovora, potpisan kao autor, objašnjava čitateljima kako je došao do stanovite rukopisne građe (vidljivo iz naslova rukopisa) ${ }^{140}$, ali za cilj nema objaviti dobivenu rukopisnu građu, već naglašava intenciju tvorbe fikcije iz fakcije, romana iz kronikalnih zapisa:

„Na osnovu spomenute rukopisne građe odlučih se napisati roman o sudbini fra Vincenca i njegova neputa Vicka..."(GOD: 10)

Na ovaj način predgovor u Gorkom okusu duše autoreferencijalno priziva kompleksnu problematiku odnosa pripovijesti i povijesti, a koja leži u osnovi pisanja svakoga romana povijesne tematike.

\footnotetext{
139 „Nije nedostajalo ništa, osim nekoliko prvih stranica. Nije ustanovljeno je li njima gospođa Venčec potpalila vatru u štednjaku ili je kestenjar u njih zamotao vruće pečene kestene..." (Držić 1994: 13)

${ }^{140}$ KRONIKA O PORIJEKLU I IMENU SELA BEZBOZI TE O SUDBINI FRA VINCENCA I NJEGOVA NEPUTA VICKA KOJI PRVI NASELI BRIJEG POVIŠE MORA, A ČIJI UNUK U KASNIJIM GODINAMA SVOJIM PREDA MI DRAGOCJENE SPISE KOJI MI POSLUŽIŠE ZA SAČINIT OVO DJELO NA JEZIKU DOMAĆEM. ANNO CHRISTIANAE M D C L. (GOD: 9, dijelove istaknula D. M. L.)
} 
Dok je kod Šehovića ova problematika tek naznačena, roman Ludwiga Bauera Kratka kronika porodice Weber (1990.) svojim predgovorom naslovljenim „Štovani čitaoče“ iscrpnije ju razrađuje.

Imenovavši se autorom „opsjednutim svojim činom“ (Bauer 2001: 7), tvorac predgovora progovara u (auto)metatekstualnome ključu ${ }^{141}$ : opravdava svoj čin pisanja, iznosi (potencijalne) nedostatke svoga ,proizvoda“, a vrline prepušta čitateljskoj recepciji.

Poput Šehovićeva autora/potpisnika predgovora i Bauerov autor, premda se oslanja na konvenciju pronađenoga rukopisa, nema namjeru objaviti dobivene zapise (kao što je slučaj u Katušićevu i Držićevu romanu), već naglašava kreaciju novoga teksta na temelju rukopisne „ostavštine porodice Weber koja je živjela u Gradecu gotovo sto i dvadeset godina“ (Bauer 2001: 7). Nastali tekst je, riječima autora predgovora, ,hibridna tvorevina“ proizašla iz „domišljanja na rubu beletristike“ (isto: 8).

Od Gizeline rukopisne kronike, koju dobiva u ruke kao ostavštinu Weberovih, autor nema namjeru načiniti djelo povijesnoga karaktera, ne samo zato što smatra da za to nema određenoga dara, već i zato što shvaća da ga „više zanimaju sudbine nego epoha“ (isto: 8). Upravo u ovoj posljednjoj konstataciji (sudbina/epoha) vidi se poveznica s predgovorom Šehovićeva romana (roman o sudbini fra Vincenca i nećaka mu Vicka) - riječ je o fokusu autora suvremenih povijesnih romana na sudbine pojedinaca na povijesnoj pozornici, i to ne na sudbine onih „,velikih“ kao ni povijesno provjerljivih, već na sudbine povijesno bezimenih. Jer Šehovićevi fra Vincenco i don Vicko, poput Bauerovih Weberovih, ,nisu bili ljudi o kojima se uspomene čuvaju u muzejima“" (Bauer 2001: 9).

Iako gore navedeno predgovorno pozivanje na rukopise koji će poslužiti kao polazište za roman (a time i oblikovanja ljudskih sudbina) - dakle tema „pretvorbe“ povijesti u pripovijest - nije nikakva novost u odnosu na klasični povijesni roman šenoinskog tipa ${ }^{142}$, distinkcija dva modela hrvatskoga povijesnog romana očituje se u vrsti i statusu građe na koju se poziva.

\footnotetext{
141 „Ako metatekstualnost shvatimo kao svijest o tekstu u širokom smislu riječi, tada autoreferencijalnost možemo odrediti kao autometatekstualnost, tj. svijest o vlastitom tekstu, odnosno samosvijest teksta." (Oraić Tolić 1993: 136)

${ }^{142}$ Npr. August Šenoa u predgovoru romana Čuvaj se senjske ruke navodi: „Znam da pripovijetka nije kronika, već umjetna cjelina, koju oživljava tvorna slika pjesnikova, nu ne nalazim razloga da se pjesnik iznevjeri povijesti ako je ona po sebi zgodna i spretna novelističkoj izradbi.“ (1995: 6)

U pogovoru romana Vuci Milutin Cihlar Nehajev ističe: „Vuci hoće da budu prije svega roman realistički - i ako je, u ovom djelu, čitav jedan simbolički odsjek povijesti Hrvata iznesen iole sa plastičnošću, koja može dočarati istinski život, sve je moje umjetničko nastojanje bilo u tom, da se ličnosti živo uoče i događaji slikovito poredaju; a da bude vazda i jedno i drugo osnovano na detalju i crtanju milieua onako kako je sav 'duh vremena' sačuvan u listovima i listinama davnim..." (1963: 425)
} 
Naime, kako je već napomenuto ranije u ovome $\operatorname{radu}^{143}$, pisci novopovijesnih romana ne pozivaju se u pravilu na „velike“ kronike od općeg značaja za neku zajednicu, već na obiteljske kronike (npr. Bauer) i kronike biografskoga karaktera (npr. Šehović), dakle neku vrstu ,intimnih“ kronika.

Osim toga, kronike na koje se referiraju spomenuti pisci nisu povijesno provjerljivi dokumenti koji obitavaju u stvarnim arhivima, poput onih koje Šenoa i pisci šenoinskog modela iznose u predgovornim bilješkama svojih povijesnih romana ${ }^{144}$. Dakle, u slučaju novopovijesnih romana riječ je o kronikama paracitatnoga karaktera jer ne postoji nikakav stvarni, realni prototekst s kojim vezu ostvaruju rukopisi iz predgovora. ${ }^{145}$

U ovome kontekstu važno je uputiti i na odnos prema izvorima na koje se poziva u predgovornim bilješkama, posebno na načelo vjerodostojnosti i težnje istini.

Dok tradicionalne hrvatske povijesne romane obilježava „historicistička pedanterija“ (Žmegač 1994: 79), gotovo neka vrsta prisege pisca kako se ,povijesti neće iznevjeriti“ (Šenoa u Seljačkoj buni i u Čuvaj se senjske ruke), suvremeni povijesni romani odnos prema dokumentima nerijetko temelje na načelu sumnje i nepouzdanosti.

Za predgovor u romanima šenoinskog tipa nezamisliva je izjava Bauerova tvorca predgovora kako je ,prisiljen odbacivati izvorni tekst““ (2001: 8).

U Katušićevu Admiralskome stijegu predgovorne bilješke navodnog urednika rukopisa naglašavaju nečitkost bilježaka izvornika, kao i nestanak samoga izvornika, čime se ukida mogućnost verifikacije ${ }^{146}$.

U predgovoru romana Magarcima pucaju rebra Lea Držića pitanje vjerodostojnosti dokumenta postavljeno je motivom oštećenih i požutjelih listova pronađenoga rukopisa ${ }^{147}$, slično kao u predgovoru romana Ivana Supeka Buna Janusa Pannoniusa, gdje klesar Miroslav kao zapisivač neke vrste oporuke pjesnika Janusa Pannoniusa naglašava kako će mu biti teško, ako ne i nemoguće, Pannoniusove zapise i usmena predsmrtna kazivanja organizirati i skupiti u nekakvu smislenu cjelinu (v. Supek 1995: 166).

Za razliku od navedenih romana, predgovor u Šehovićevu Gorkome okusu duše ne signalizira sumnju u vjerodostojnost rukopisa na bilo koji način (uništeni, nečitki, kaotični ili izgubljeni rukopisi), ali ne ističe ni ono šenoinsko načelo provjerljivosti.

\footnotetext{
${ }^{143}$ Vidi potpoglavlje o kronikama u okviru diskurzivne klasifikacije dokumenata.

${ }^{144}$ Vidi u potpoglavlju ovoga rada „Dokument u povijesnom romanu“.

${ }^{145}$ O vrsti citatnoga podudaranja vidi u: Oraić Tolić (1990: 18 - 21).

146 „Tako su ovi spisi ostali bez svog temeljnog pokrića. (...) Poučak: rukopise treba čuvati, osobito ako se radi o unikatima.“ (1987: 29)

${ }^{147}$ Vidi predgovor Držićeva romana naslovljen „Umjesto uvoda“ (1994: 11 - 13).
} 
U Šehovićevu predgovoru čitav odnos prema (povijesnome) dokumentu sažet je u već spomenutome citatu o pretvorbi rukopisne građe u roman koji će iskazati „sudbinu“ fra Vincenca i don Vicka. Upravo je time pomaknut naglasak od pitanja autentičnosti i provjerljivosti informacija na zahtjev prepoznatljivosti ljudskih sudbina omogućenih jedino literarnim diskursom.

Kao što je ranije kazano, i Šehovićev predgovor, poput predgovora u tradicionalnome povijesnom romanu ističe načelo analogije, u smislu da ono prošlo progovara (i) o sadašnjemu - ,jer je prošlost vazda zrcalom sadanjeg vremena“ (Šenoa 1991: 25). Potpisnik predgovora, naime, uvjeren je da muka fra Vincenca i nećaka mu Vicka „ne pripada samo davnom šesnaestom stoljeću“ (GOD: 10). Razlika pak leži u načinu odnošenja prema slici prošlosti: nastavak romana ukazuje da je mogućnost učenja iz prošloga zamijenjena idejom repetitivnosti prošlih muka. Čitajući predgovor Gorkoga okusa duše, u najavljenom prikazu Vincencove i Vickove „muke“ čitatelj zato ne treba očekivati uzorak za učenje, u smislu izbjegavanja onoga što je zadesilo Šehovićeve protagoniste ${ }^{148}$, već svevremensku paradigmu muke.

Za Julijanu Matanović predgovorne bilješke romana Stjepana Tomaša Zlatousti najviše nalikuju predgovorima u tradicionalnome povijesnome romanu.

Uvodno poglavlje romana (Uvod) podnaslovljeno je kao „Strossmayerov curriculum vitae i kronološki pregled važnijih događaja u Hrvatskoj i Europi od 1848. do 1905. godine““ (v. Tomaš 1993: 7 - 20), pri čemu Strossmayerov životopis i kronološki pregled preuzimaju na sebe funkciju predgovornih bilježaka povijesne varijante hrvatskoga povijesnog romana riječ je o iznošenju povijesno provjerljive literature kojom se autor koristio u fazi koja je prethodila pisanju beletrizirane povijesti (v. Matanović 2003: 137).

Međutim, odmak od takva prvotnoga zaključka, odnosno pomak prema poetici novopovijesnoga romana, realiziran je pripovjedačevim intervencijama u taj ,jaki dokument“, koje se temelje na komentatorskim dionicama, kao i na izboru onih povijesnih događaja koji će potvrditi ideju cikličnosti povijesti (isto: 137 - 138).

Iz obuhvaćenoga korpusa novopovijesnih romana (Magarcima pucaju rebra Lea Držića, Gorak okus duše Feđe Šehovića, Admiralski stijeg Ivana Katušića, Kratka kronika

\footnotetext{
${ }^{148}$ Usp. predgovor Šenoina romana Seljačka buna: „Dobro je da narod sazna gdje je zgriješio i posrnuo, gdje li se proslavio i prodičio. To neka mu je naukom za buduća vremena. Poznata je odavna, ali vazda istinita ona riječ staroga Rimljanina 'Historia vitae magistra'“، (1991: 25)
} 
porodice Weber Ludwiga Bauera, Buna Janusa Pannoniusa ${ }^{149}$ Ivana Supeka i Zlatousti Stjepana Tomaša) $)^{150}$ mogu se okvirno utvrditi sljedeći predgovorni modusi:

pisac predgovora nastupa kao pronalazač i urednik bilježaka (Katušić, Držić); autor predgovora pozicioniran je kao svjedok događaja o kojima stvara naknadne zapise (Supek); predgovorne bilješke zasnivaju se na prezentaciji povijesnoga konteksta putem ,jakog dokumenta s intervencijom pripovjedača“ (Tomaš) ${ }^{151}$; pisac predgovora ostvaren je kao fiktivni autor koji naglašava pretvorbu povijesti u pripovijest (Šehović, Bauer).

U kontekstu definicije predgovora kao paratekstualne formacije (Genette), u smislu graničnoga prostora između unutrašnjosti teksta i izvantekstovnoga prostora, može se uočiti razlika između klasičnog hrvatskog povijesnoga romana i novopovijesne varijante.

Predgovori u povijesnoj varijanti (npr. Šenoa, Kumičić, Nehajev) funkcioniraju kao „granični tekstovi između autorove teorije i prakse“ (Matanović 1998: 45), u kojima se stvarni autori (potpisani svojim imenom i prezimenom) obraćaju svojim čitateljima, pripremajući ih na fiktivni svijet koji će uslijediti nakon predgovornih bilježaka.

U Šehovićevu Gorkom okusu duše, kao i ostalim primjerima novopovijesnih romana, predgovorne bilješke simuliraju obraćanje stvarnoga autora; ne funkcioniraju ni jednim svojim dijelom na izvanfiktivnoj razini, već su u cijelosti neupitan segment fikcionalnoga svijeta teksta.

\subsubsection{Fusnote}

Prema Gérardu Genettu bilješka se kao paratekstualna tvorba pojavljuje na samoj granici koja „okružuje eminentno tranzicijsko polje parateksta“ (Genette prema Buljubašić 2017: 33), a definirana je kao ,iskaz varijabilne duljine (jedna riječ je dovoljna) povezana s manje ili više određenim segmentom teksta te je postavljena njemu nasuprot ili je za njega pričvršćena“ (isto).

\footnotetext{
${ }_{150}^{149}$ Supekov roman uz predgovorne bilješke sadrži i one pogovorne.

${ }^{150}$ Romani su, s obzirom na godinu izdanja, poredani kronološki.

${ }^{151}$ Riječ je o određenju Julijane Matanović (v. 2003: 136 - 138).
} 
Fusnote kao podvrstu bilježaka ${ }^{152}$ Šehović kontinuirano koristi u gotovo svim svojim povijesnim romanima, s tim da su fusnote uvijek povezane s (testimonijalnom) dokumentacijom na kojoj počiva fabularni ustroj.

Ovaj romanopisac posredstvom fusnota redovito upućuje na nazive i autorstvo dokumenata, a često i na njihovo vrijeme nastanka / godinu izdanja:

-,Ulomak iz prvoga dijela Menčetićeva rukopisa „DE INFERNIS ANNOTATIONES“ (Zapisi o paklu)“ (OĐ: 9) ${ }^{153}$

-,,Iz pisma F. P. de Bobali, 18. travnja 1667. „,(OĐ: 160)

- „Zapisi o padu i oslobađanju Klisa, po rukopisu fra Marka Anđelovića Život i djelo pravednika fra Andrije A. i njegova uzora fra Ilije K., 1689.“ (PE: 15)

- „O životu i djelu uzora fra Ilije, 1648.“(PE: 31)

-,,Po rukopisu fra Matije Kopčića DE - ILIAS-BEG VITA ET REBUS COMMENTARIUS, 1696.“(I: 7)

-„Po rukopisu trebinjskog kadije Ahmet-age Karamehmedovića“ (I: 27)

-,Po Enesovu kazivanju“ / „Po Sultanijinim zapisima“ (I: kontinuirano u romanu Inšallah)

U romanu Oslobađanje đavola govorne značajke iskaza svjedoka realizirane su uporabom latinskoga i talijanskoga jezika te staroga dubrovačkog govora i grafije (Dubrovnik druge polovine 17. stoljeća), zbog čega se po frekventnosti ističu fusnote translatorskoga karaktera.

Takve fusnote znaju biti vrlo kratke, kao što su u slučaju „prevođenja“ latiniziranih imena likova, primjerice Simeon Matthei de Ghettaldis - Šimun Getaldić (OĐ: 125), ser Nicolinus Marci de Basilio - Nikolica Basiljević (OĐ: 125), ser Ioanes Marcio de Saraka - Gjivo Saraka (OĐ: 143).

S druge strane, manje ili više opširne su u situacijama prevođenja i grafijske prilagodbe segmenata zapisa svjedoka (kronike, pisma, izvještaji i sl.).

Kao reprezentativan primjer može poslužiti navod iz pisma ser Francisca Paolija de Bobalija (18. travnja 1667.)

Per il mal governo siamo castigati e per peggiore afatto estirpati, i xuala Bogu na onemu scto on cini, ma scto sli gliudi cine nemosce ciouiek biti patienat, e se non

\footnotetext{
${ }^{152}$ Kao vrstu bilježaka Genette navodi glose, margine teksta te fusnote. (Genette prema Buljubašić 2017: 33)

${ }^{153}$ Radi ekonomičnosti u zagradama će se navoditi već ranije korištene kratice naziva Šehovićevih romana, uz broj stranice: Gorak okus duše (GOD); Oslobađanje đavola (OĐ); Uvod u tvrđavu (UUT); Prokleta ergela (PE); Ilijasbegovići (I).
} 
fosse bestemia na uieru bix reko sascto me, Bosce, zasto me ostaui u sciuotu da gledam ouaku miseriu come Gierusaleme destrutto e Troia incendiata. “( (OĐ: 167 - 167),

preveden i prilagođen u fusnoti na sljedeći način:

„Kažnjeni smo zbog lošeg vladanja i za našu nesreću iskorijenjeni, i hvala Bogu na onome što čini, ali prema onome što zli ljudi čine čovjek ne može biti strpljiv, i kad ne bi bio grijeh, vjere mi moje, rekao bih: 'Bože, zašto me ostavi u životu da gledam ovakvu bijedu sličnu razorenu Jeruzalemu ili spaljenoj Troji...'“(OĐ: 167)

U okvirima hrvatskoga povijesnog romana, kako povijesne varijante tako i one novopovijesne (ali i romana općenito), fusnote prevodilačkoga karaktera nisu ništa neuobičajeno. Katkada ih umeću sami autori, a katkad nastaju kao rezultat urednikove pripreme teksta za čitatelja.

U kontekstu novopovijesnoga romana bogatstvo translatorskih fusnota vidljivo je primjerice $u$ Fabrijevoj Jadranskoj trilogiji. Riječ je o prijevodima najčešće s talijanskoga jezika, latinskoga, njemačkoga (Vježbanje života, Berenikina kosa), ali i sa švedskoga (Triemeron). Razlika između Šehovića i Fabrija, u ovom slučaju, leži u odnosu između dokumenta i fusnote. Kod Fabrija se ne ostvaruje ona korelacija dokumentaristike i fusnote vidljiva u Šehovićevim romanima. Naime, Šehovićeve fusnote uvijek su povezane s fiktivnom dokumentacijom na kojoj se gradi priča, bilo da se putem fusnote poziva na naziv i karakteristike dokumenta, prevode određeni segmenti dokumenata, ili pak komentiraju obilježja i status dokumenata.

Fusnote u kojima se više ili manje opširno donose deskriptivna obilježja rukopisa te komentari stanovitoga kazivača priče najočitije su u Oslobađanju đavola, ali u manjoj mjeri prisutne su u Gorkom okusu duše i ciklusu Ilijasbegovići:

-,(...) Pisac se nekoliko puta poslužio stihovima Stjepa Gradića, ali ne spominjući njegovo ime, vjerojatno zato da se ne zamjeri fra Mavru, koji je i poslije trešnje jednako prezirao Gradića i njegovu poeziju.“(OĐ: 8) 
-,U svojoj kraćoj raspravi 'Aut nihil aut veritas' L. M. De Pozza proriče budeće potrese u gradu Dubrovniku i najbližoj okolici: 1632., 1657., 1667., (...) 2018. Mjesece nije označavao, a godine za koje misli da će se dogoditi katastrofalan potres, dva puta je podvukao. To su 1667. i 2018.“(OĐ: 12)

-„Rukopis g. Hardena čuva se u Mazarinovoj biblioteci u Parizu.“(OĐ: 166)

-,,Sve ove pjesme nastale su u posljednjem desetljeću Vickova života, a tiskane su u slobodnom prijevodu s latinskog. U nedostatku naslova, označene su rimskim brojevima od I - XXV, a pisac romana ih je dodao kao posljednju (IX) glavu.“ (GOD: 146)

-,Završavajući u Zagrebu ovu pripovijest o svojem dječaštvu, točno tri godine nakon mojeg dolaska u Mostar da nastavim osmi razred gimnazije i maturiram, prisjetio sam se Sarajkina gatanja u vlaku. Nisam zbog toga osjetio strah da se obmanjujem željom za pisanjem. Jedino se bojah mogućnosti iskrivljavanja istine u svojim sjećanjima. „(I: 724)

Komentatorske fusnote do izražaja dolaze i u Fabrijevu Triemeronu, ali kako je već kazano, one u pravilu nisu u vezi s dokumentacijom na kojoj se gradi fabula ovoga romana ${ }^{154}$. Fabrijeve fusnote komentatorskoga karaktera, obilježene sintagmom „Bilješka pisca“ (1 - 7), postmodernistički su zaigrane. Uglavnom su (auto)metatekstualne prirode budući da se referiraju na izgradnju samoga književnoga svijeta ${ }^{155}$, poigravajući se katkad u ekstremnim razmjerima granicama fikcije i fakcije ${ }^{156}$, čime se u čitatelju proizvodi efekt „kratkoga spoja“

\footnotetext{
${ }^{154}$ Tek je jedan takav primjer. Vidi „Bilješku pisca, 3“ (2002: 61), u kojoj se u sklopu fusnote nastoji pridati vjerodostojnost osnovnoj priči citiranjem dijelova iz sljedećih dokumenata: Milan Marjanović, Narod koji nastaje: Zašto nastaje i kako se formira jedinstveni srpskohrvatski narod (1913); Ante Trumbić, Elaborat o hrvatskome pitanju (1932).

${ }^{155} \mathrm{Npr}$. „Bilješka pisca, 2: (...) načinom na koji je vaš pisac, susretom s Vilom domaće povijesti, popunio paralizirajuću prazninu u svome pripovijedanju može učiniti nezadovoljnima samo one koji u suhoj potrebi da dokuče Menegovu kob pristupaju ovoj razložno, hoteći tražiti i prepoznavati nositelje gentilne, a time i narodne tradicije, tamo gdje ih nema." (2002: 36)

${ }^{156}$ Bilješka pisca, 1: „Ubacujući na ovome mjestu u igru izraz autsajderi, pisac vrlo vješto aludira na jednu od ključnih tema, onu autsajderstva, u hrvatskoj književnosti tijekom razdoblja socijalističke Jugoslavije, o čemu podrobnije možete čitati u Gotovca, Šoljana i u drugih autsajdera" - reći će spisateljica najfinijega osjećaja za umjetnost riječi u suvremenoj hrvatskoj književnosti Julijana Matanović studentima književnosti na svojim predavanjima.“ (2002: 19)
} 
(Lodge 1988: 283) budući da se razbija ,jaz između teksta i svijeta, između umjetnosti i života“" (isto: 284).

Na tragu primjera fusnota iz Šehovićevih povijesnih romana može se potvrditi koliko su ovakve bilješke povezane isključivo s razinom testimonijalne dokumentacije paracitatnoga karaktera.

Među povijesnim romanima novopovijesne varijante ovakvo fusnotno pozivanje na paracitatnu dokumentaristiku može se zamijetiti u ranije spominjanom romanu Ivana Katušića Admiralski stijeg.

Kao i Šehoviću, i Katušiću su fusnote u tome kontekstu poslužile kao mjesto izgradnje vjerodostojnosti, autentičnosti, nekakvoga ,povjerenja“ u paracitatni dokument na koji se poziva.

S obzirom da je tematika Katušićeva romana vezana uz pravnu istragu protiv Vicka Viribusa, i fusnote su oblikovane u svjetlu juridičke i historiografske formulaičnosti:

„,iz dokumenata se može ustanoviti“ (1987: 96); ,jedan je austrijski historiograf zabilježio“ (isto: 134); , „u kasnijim izvorima zabilježeno je“ (isto: 147)...

U svjetlu dosad iznesenoga može se zaključiti kako fusnote različitih funkcija (fusnote s nazivima rukopisa, translatorske fusnote, fusnote s deskripcijom i komentarima rukopisa) predstavljaju jedno od prepoznatljivih mjesta u Šehovićevim povijesnim romanima. Na tom tragu, po frekventnosti i raznorodnosti fusnota, ističe se roman Oslobađanje đavola. S druge strane, korištenje fusnota zaobišlo je roman Uvod u tvrđavu budući da je forma toga romana, kako je ranije kazano, u cijelosti zasnovana na kompilaciji raznovrsne dokumentacije, na situaciji ,rukopisa koji sami govore“.

Posljednje pitanje (a možda i ključno) koje valja postaviti jest: Kakav efekt proizvode fusnote u Šehovićevim povijesnim romanima?

Na putu do odgovora valja krenuti od funkcije fusnota u njihovu ,prirodnome okruženju“- $u$ znanstvenim radovima. Fusnote su tako, primjerice, „obvezan oblik citatnica u akademskim radovima iz humanistike“, korišten prvenstveno kao područje argumentacije (v. Oraić Tolić 2011: 456 - 457).

Za G. Genetta bilješke (a time i fusnote) u tekstovima koji su i sami diskurzivni (historiografski tekstovi, eseji itd.) potpuno su očekivane i učestale, dok za one (rijetke) u književnosti (npr. u pripovjednim, dramskim i poetskim tekstovima) ovaj teoretičar kaže kako „krase ili nagrđuju“ djelo (v. Genette prema Buljubašić 2017: 33). 
Tako fusnote u književnome djelu, čak i kad nastoje fingirati dojam znanstvene provjerljivosti i vjerodostojnosti, zapravo,,nemaju argumentacijsku nego estetsku funkciju“ (Oraić Tolić 2011: 456).

Iako se fusnote definiraju kao paratekst, u smislu ,praga“, „,nedefinirane zone“ između onoga unutar i izvan teksta (v. Grdešić 2015: 111), interpretativni kontekst Šehovićevih povijesnih romana navodi na povezivanje fusnota s pripovjedačkom instancom. U slučaju Gorkoga okusa duše, Oslobađanja đavola, Proklete ergele i većeg dijela Ilijasbegovića riječ je o pripovjedaču koji je nadređen priči i stoji izvan nje, dakle riječ je o ekstradijegetičkome-heterodijegetičkome pripovjedaču, dok fusnota pri kraju Dubrovačkoga intermezza kao četvrtoga romana u ciklusu o Ilijasbegovićima uključuje glas Ilijas-bega kao homodijegetičkoga pripovjedača.

Stoga, kao i u slučaju predgovornih bilježaka u Šehovićevu romanu Gorak okus duše, ove naizgled paratekstualne tvorbe zapravo su isključivo dio fiktivnoga svijeta teksta.

Za razliku od bilježaka u tradicionalnome povijesnom romanu, kojima se pozivanjem na provjerljive povijesne dokumente nastojalo osigurati autentičnost i vjernost „povijesnoj istini““157, paracitatna priroda dokumenata na koje se poziva u fusnotama Šehovićevih romana ostvaruje sasvim suprotne efekte, stvarajući neku vrstu proturječja - njima se istovremeno „upisuje i podriva objektivnost historijskih izvora i objašnjenja“ (Hutcheon 1988: 123).

\subsubsection{Pozivanje na dokument u okviru osnovnoga teksta}

U cilju postizanja zornosti i ujednačenosti terminologije, koristit će se sintagma „osnovni tekst““ (v. Matanović, npr. 2003: 134) ${ }^{158}$ kako bi se ta razina romana razgraničila od ranije spomenutih paratekstualnih kategorija kao što su predgovori/pogovori, bilješke (npr. fusnote) i sl. Upravo su paratekstualni oblici bili mjesta na kojima su pisci povijesne varijante povijesnoga romana „upozoravali čitatelja na povijesnu istinitost onoga o čemu pripovjedač kazuje“" (isto: 134).

\footnotetext{
${ }^{157}$ V. npr. opširne bilješke u „Tumaču“ na kraju Šenoina romana Zlatarovo zlato, za koje Šenoa napominje kako su nastale „da se vidi ukoliko je ovaj roman crpljen iz povijesti i da se neka mjesta bolje razumiju“ (2004: 289). ${ }^{158} \mathrm{Uz}$ „,osnovni tekst““ Julijana Matanović kao sinonimski izbor koristi „,središnja priča“, „,pripovjedni dijelovi“... (usp. 1998; 2003).
} 
Govoreći o inkorporaciji dokumenata na primjeru Fabrijevih romana, s napomenom da je tako u većini romana novopovijesne varijante, Matanović kao dominantan način vidi situaciju kad se „uvjeravački prostori umeću između pripovjednih dijelova“ (2003: 135), dakle u okvirima tzv. osnovnoga teksta.

Osim uobičajenoga nadovezivanja citata u osnovnome tekstu, Fabrijevo pozivanje na dokument uključuje i prepoznatljive grafičke markacije korištenjem isprekidanih crta (v. Matanović 1998: 285 - 286).

Iako, kako je to ranije u ovome radu pokazano, Šehović koristi i predgovor te fusnote kao paratekstualne prostore u cilju upućivanja na dokumente svjedočenja, njegovi se pripovjedači redovito, u svim povijesnim romanima, pozivaju na izvore i u okviru osnovnoga teksta. Čini se to dvojako - posredstvom upravnoga ili neupravnoga govora.

U prvome slučaju pripovjedač se koristi izravnim pozivanjem na tekst dokumenta pomoću citata obilježenih navodnim znakovima ili kurzivom, primjerice:

-,(...) kao što je zasigurno mislio i moj prethodnik prognanik fra Mavro S. pišući svoju Kroniku, iz koje ću za kraj ovoga predgovora posuditi samo dvije rečenice. Prva se odnosi na Vincenca: 'Uobičajeno je da se život naruga ljudskim snovima, kao što je uobičajeno da u takvim okršajima uvijek pravo dajemo životu, iako bismo ljudskije razmišljajući lako došli do zaključka da najčešće sa životom nešto nije u redu a ne sa snovima.' Druga je posvećena Vicku i glasi: 'Pravu nesreću pjesnik ne vidi u mogućem rušenju stvarnoga svijeta, već onog nestvarnog u kojega je tako duboko vjerovao."“(GOD: 10)

-,Najviše primjedbi ispisano je na marginama drugog dijela rukopisa, koji je sudac Andro počeo stihovima iz Mavrine poeme 'Oslobađanje đavola': 'NE PITAJTE ME OTKUD ZNAM ŠTO JE PAKAO, JER ŽIVIH U NJEMU!'‘ (OĐ: 169)

-,U toj knjizi fra Ilija nije propustio priliku naglasiti primjer kršćanskog Dubrovnika, 'koji radije žrtvuje dobar dio svog zlata, negoli svoju državu, kupujući dankom tursku zaštitu.'"'(PE:12)

-,, 'Moguće su i takve promjene u ljudi' zapisuje Ahmet-aga, 'jer milost Božja je velika, a ljubav spram voljena bića u nama ne poznaje granica.'“ „, (I:19) 
-,ZZanesena Sultanija ustvari napamet ponavlja u sebi Hasan-begove riječi iz njegova kraćeg, sačuvanog zapisa o knjizi plemenitog gospara Antuna: Dokle ćemo ispaštati izmišljeno otpadništvo?! Bosno naša, nek ti Alah da pameti i duga strpljenja da izbjegneš zamke vlastitih zabluda i tuđe zloće, da ostaneš vjerna duboku preziru spram svake isključivosti.“ (I: 312)

U Šehovićevim povijesnim romanima mnogo su češća pozivanja pripovjedača na tekst dokumenta putem neupravnoga govora, u smislu pripovjedačeva prepričavanja zapisanih riječi svjedoka, kako demonstriraju sljedeći navodi:

-,Fra Vincenco je i previše poštovao starca da bi posumnjao u istinitost njegova kazivanja ali, kako navodi Vicko u svojim bilješkama, nije prihvaćao njegove zaključke koje je kao uvijek, u sličnim prilikama, smatrao beznadnim i bogohulnim.““ (GOD: 49)

- „U njemu, kako bilježi sudac Andro, živi ona smjelost tragača za neznanim, koju posjeduju samo istinski nadareni pjesnici (...).“(OĐ: 104 - 105)

- „Po fra Matijinom kazivanju, ser Gjivo se tada prvi put susreo s Ilijas-begom u Čilipima na imanju rođaka Lukice, gdje je iz Gornjih Konavala noću doveden zajedno s dvojicom svojih sejmena." (I: 48)

- „Zločeste su laži, piše fra Marko, da se njegov uzor fra Andrija udaljio od svog zavjeta redu i vjeri, ali priznaje da je počeo sumnjati u nedodirljive istine (...)“(PE: 172)

Prilikom usporedbe s korištenjem fusnota i predgovornih bilježaka, može se uočiti da pozivanje na testimonijalne zapise u sklopu osnovnoga teksta, bilo posredstvom citata (navodni znakovi / kurziv) ili pripovjedačevim prepričavanjem riječi svjedoka, predstavlja najfrekventniji način inkorporacije dokumenata $\mathrm{u}$ analiziranom korpusu romana Feđe Šehovića, ali i kod ostalih predstavnika hrvatskoga novopovijesnog romana. 


\subsubsection{Roman kao zbir(ka) dokumenata}

Iz dosadašnjeg izlaganja o inkorporaciji dokumenata u Šehovićevim romanima može se zapaziti izostanak primjera iz romana Uvod u tvrđavu: Biblija za nevjernike. Naime, u ovome romanu na dokumente se ne poziva unutar osnovnoga teksta, kao ni u sklopu paratekstualnih prostora (predgovora, fusnota i sl.).

Riječ je o primjeru romana koji se, u tome kontekstu, prema dokumentu odnosi na najradikalniji mogući način - čitav roman zapravo je zbir(ka) dokumenata različitih diskurzivnih značajki: tekstovi koji se mogu promatrati unutar žanra tzv. testimonijalne literature, pisma, dnevnički zapisi, kronika, poslanice te govorenje svjedoka (primjer usmenoga iskaza).

Nije prisutan nikakav konkretan narativni okvir u smislu predgovornih/pogovornih bilježaka ili fusnota u kojima bi se autor/pronalazač/urednik navedenih dokumenata obratio čitateljima objašnjavajući kako je došao do rukopisa i što će s njima učiniti (što je jedno od stalnih mjesta konvencije pronađenih zapisa). Mogućnost opisane posredničke instance eventualno se dade naslutiti u naslovu posljednjega dokumenta koji čini kompozicijsko ustrojstvo ovoga romana: Sastavljačeva kratka kronika daljnjih zbivanja. Spomenuti „sastavljač“ može tek uvjetno preuzeti takvu ulogu jer riječ je o Raulu Mitrovichu - liku iz romana, a ujedno i pseudonimu Feđe Šehovića pod kojim je i izašao ovaj roman, čime se razbijaju čak i one zamišljene granice između svjetova fikcije i fakcije.

Ukinuta je ideja bilo kakve čvrste kategorije ,,autora“ koji posredstvom dokumenata stvara povijesnu priču. Pred čitatelja su stavljene tek hrpe dokumenata koji sami govore/kazuju priču, dovodeći tako do ekstremnih razmjera ideju L. Hutcheon o isključivo tekstualiziranoj dostupnosti prošlosti. 


\subsection{Dokument kao prostor intertekstualnih relacija}

\subsubsection{Intertekstualnost u teorijskome okruženju}

Za francuskoga teoretičara Gérarda Genetta (1997.) intertekstualnost je tek jedan od tipova transtekstualnosti /tekstualne transcendencije ${ }^{159}$, u smislu svih odnosa u koje stupa tekst s obzirom na druge tekstove (isto: 1 ).

U okviru transtekstualnosti intertekstualnost podrazumijeva odnos suprisutnosti (međuprisutnosti) ${ }^{160}$ između dvaju ili nekolicine tekstova, pri čemu je jedan tekst ,prisutan“ $u$ drugom putem navoda, plagiranjem ili aluzijama (isto: 1 - 2).

Pod intertekstualnošću Julia Kristeva, autorica ovoga termina, podrazumijeva „transpoziciju jednog ili nekoliko sustava znakova u neki drugi sustav“, pri čemu redovito dolazi do redistribucije značenja, tj. do nove artikulacije (1984: 59 - 60).

Kako se pojam ,intertekstualnost“" nerijetko miješa s proučavanjem izvora, Kristeva ipak prednost daje kategoriji „transpozicije“ jer se njome naglašava prijelaz iz sustava u sustav (1984: 60).

I za Rolanda Barthesa intertekstualnost kao svojstvo teksta ne smije se miješati s podrijetlom teksta jer ,pokušati naći izvore, utjecaje nekog djela znači upasti u klopku mita podrijetla“ (1999b: 205) ${ }^{161}$. Ovaj teoretičar intertekstualnost izričito definira kao opće svojstvo svakoga teksta, a ne specifično svojstvo nekih tekstova:

\footnotetext{
${ }^{159}$ U uvodnome dijelu svoje knjige Palimpsest (1982.) Genette navodi i objašnjava pet tipova transtekstualnih odnosa - intertekstualnost, paratekstualnost, metatekstualnost, arhitekstualnost i hipertekstualnost - naglašavajući da ovi vidovi tekstualne transcendencije nisu međusobno strogo odvojeni.

S obzirom da je u gornjemu tekstu već dana definicija intertekstualnosti iz Genettove vizure, u nastavku se potrebno, makar u kratkim crtama, osvrnuti na definicijske obrise preostala četiri tipa transtekstualnih odnosa. Već ranije spominjanja paratekstualnost (v. potpoglavlja ovoga rada o predgovorima i bilješkama u kontekstu inkorporacije dokumenata) obuhvaća naslove, podnaslove, predgovore, pogovore, bilješke, ilustracije, posvete i slične „sekundarne signale“, u smislu elemenata jednoga teksta na koje se referira u drugome tekstu (1997: 3). Metatekstualnost se temelji na kritičkom odnosu među tekstovima budući da je jedan tekst komentarom povezan s drugim tekstom (isto: 4 ).

Arhitekstualnost obuhvaća „,jelokupan set generalnih ili transcendentnih kategorija - tip diskurza, moduse izraza, književnih žanrova - iz kojih proizlazi svaki pojedinačni tekst“ (isto: 1); pri čemu određivanje žanrovskog statusa teksta (kao jednog aspekta arhitekstualnosti) najčešće ne proizlazi iz kategorizacije unutar samoga teksta, koliko iz recepcije čitatelja i kritike (usp. isto: 4).

Hipertekstualnost se temelji na bilo kojoj vezi između teksta A (hiperteksta) i „ranijeg“ teksta B (hipoteksta), gdje je hipertekst svaki tekst (a ne samo komentar hipoteksta) koji je izveden iz nekog ranijeg teksta (hipoteksta) putem direktne ili indirektne transformacije (isto: 5).

${ }^{160} \mathrm{U}$ engleskome prijevodu korišten izraz ,,copresence“.

${ }^{161}$ R. Barthes u svome eseju „Od djela do teksta“(v. 1999b: 202 - 207) povlači razliku između djela i teksta. Za razliku od djela kao materijalnoga objekta, tekst je sadržan u jeziku te se može doživljavati samo u djelatnosti proizvodnje.
} 
„Intertekstualno u svakom tekstu je sadržano, budući da je ono samo međutekstovlje nekoga drugog teksta...(isto: 205).

Upravo na spomenutoj percepciji teksta kao međutekstovlja teoretičarka Renate Lachmann gradi svoju ideju o pamćenju teksta kao njegovoj intertekstualnosti, odnosno tvrdi da je „prostor između tekstova istinski prostor pamćenja“ (2002: 208).

„Kao što tekst stupa u kazalište pamćenja kulture kao u kakav vanjski prostor, on isto tako još jednom kreira to kazalište uvodeći druge tekstove u svoj unutarnji prostor. (...) Ne mijenja li svaki tekst prostor pamćenja utoliko što mijenja arhitekturu u koju se upisuje? Prostor između tekstova i prostor u tekstovima koji nastaje iz spoznavanja prostora između tekstova nadaje napetost između ekstratekstualnog-intertekstualnog i intratekstualnog koju čitatelj mora 'izdržati'. Prostor je pamćenja upisan u tekst na isti način na koji se tekst upisuje u prostor pamćenja.“ (2002: 208)

Ovakvim pristupom Lachmann se nadovezuje i na spomenuto Kristevino tumačenje intertekstualnosti kao fenomena koji dovodi do redistribucije značenja i novih artikulacija u okviru književnosti kao stanovitoga znakovnog sustava.

Iz navedenoga se može sumirati kako je svaki tekst ujedno i intertekst jer se uvijek nalazi u spletu drugih tekstova, pri čemu ga upravo odnosi s drugim tekstovima ključno određuju. Iz toga proizlazi da su svi tekstovi obilježeni intertekstualnošću pa ne postoje tekstovi koji su, primjerice, ,intertekstualniji“ od drugih.

Razliku predstavlja tek činjenica da neki tekstovi svojstvo intertekstualnosti eksplicitno signaliziraju, primjerice odnos prema drugim tekstovima naglašavaju najčešće pomoću citata. Citatnost, podsjeća Vladimir Biti, ulazi u suvremenu teorijsku raspravu usporedno sa zapadnoeuropskom recepcijom Mihaila Bahtina početkom 70-ih godina. Bahtin se zanima za „tuđu riječ, dijalošku riječ, dvoglasje, raznorječje, slobodan neupravan govor, parodiju, fenomene karnevalskog““( Biti 2000a: 39).

Valja naglasiti kako je citatnost tek jedan vid intertekstualnosti. Dubravka Oraić Tolić (v. 1990: 9 - 18), koja se iscrpno bavila ovom problematikom, citatnost vidi kao eksplicitnu intertekstualnost, gdje je citatna relacija postala dominantom nekoga teksta, autorskoga idiolekta, umjetničkoga žanra, stila ili kulture u cjelini. Tako je za ovu teoretičarku citatnost mnogo uži, određeniji, a time i egzaktniji pojam od intertekstualnosti. 
Kod citatnosti je riječ (prema Oraić Tolić) o javnome ili skrivenome podudaranju između fenoteksta (vlastitoga teksta, teksta koji citira) i genoteksta (predteksta, teksta iz kojeg je citat preuzet). Znakovi vanjske signalizacije (navodni znakovi, drugi tip slova, točnije podatci o genotekstu iz kojeg citat potječe) nisu nužni da bi se govorilo o citatnoj relaciji.

Nerijetko je pak riječ o intertekstualnim aluzijama - praznoj implicitnoj intertekstualnoj vezi u kojoj ne postoji zajednički tekst (intertekst, citat).

U nastavku ovoga poglavlja rada, u svjetlu dosad iznesenih teorijskih postavki o intertekstualnosti, sagledat će se dokumenti u Šehovićevim povijesnim romanima u kontekstu prostora intertekstualnih relacija, i to kako na „vanjskoj razini““ - prema tekstovima književne tradicije, tako i na „unutarnjoj“ razini - odnosom tekstova unutar pojedinih Šehovićevih romana.

\subsubsection{Intertekstualnost testimonijalnoga zapisa u kontekstu književne baštine}

Cilj je ovoga dijela rada - na primjeru Vickove pjesničke zbirke unutar Gorkoga okusa duše - ukazati na neke intertekstualne značajke testimonijalnoga zapisa iz Šehovićevih povijesnih romana romana u kontekstu književne baštine.

Kako je već ranije u ovome radu navedeno, Vickova pjesnička zbirka predstavlja pjesnički iskaz svjedoka događaja o kojima se govori u prethodnim poglavljima romana, čime joj je dana ovjeravateljska uloga.

Vickove su pjesme, kako se navodi u fusnoti devetoga poglavlja romana,

„,nastale u posljednjem desetljeću Vickova života, a tiskane su u slobodnom prijevodu s latinskoga. U nedostatku naslova, označene su rimskim brojevima I - XXV, a pisac romana dodao ih je kao posljednju (IX) glavu“ (GOD: 146).

Oslanjajući se na definicije i podjele citata što ih donosi Dubravka Oraić Tolić (v. 1990: 15 - 31), Irena Lukšić u pogovoru romana Gorak okus duše 162 napominje kako

\footnotetext{
162 Šehović, Feđa. 1996. Gorak okus duše. Zagreb: Školska knjiga.
} 
„,pripovjedač (skriptor!) ove pjesme predstavlja kao realne izvore svoga teksta, a zapravo su autorska mistifikacija. Tako postignuta citatnost je prazna (istaknula D. M. L.), jer ne korespondira sa zbiljskim materijalima iz kulturnog prostora na koji se poziva“" (1996: 170). Oraić Tolić (v. 1990: 18 - 19) ističe kako je glavna značajka praznih (vakantnih) citata ogoljivanje, a time i razotkrivanje kategorijalnoga citatnog trokuta (citat - vlastiti tekst - tuđi tekst, tj. citat - fenotekst - genotekst), dakle razotkrivanje same relacije podudaranja koja je za citatnu intertekstualnost bitna.

U skladu s tim, prema navedenoj teoretičarki citatnosti, vakantni citati govore da u sferi intertekstualnosti vlastiti tekst može početi i bez tuđega predteksta, kao da prethodna kultura za novi tekst nije važna - zato su vakantni citati najradikalniji oblik intertekstualne kreacije ex nihilo.

Iako je Vickova pjesnička zbirka na prvi pogled zaista školski primjer vakantnoga citata, i to paracitata kao podvrste ${ }^{163}$, što bi značilo da se ovaj tekst ne oslanja na neki stvarni tekst postojećeg (književnog) sustava, pažljivijim iščitavanjem dolazi se do spoznaje o njegovoj „ispunjenosti“ snažnim intertekstualnim referencama.

Petnaesta pjesma Vickove zbirke može se promatrati kao centralna pjesma ovoga paracitatnoga opusa. Uz snažne aluzije na neka druga djela, ta je pjesma i nositeljica naslova Šehovićeva romana Gorak okus duše. Time joj je priskrbljen položaj značenjske jezgre ne samo Vickove zbirke, već i romana u cijelosti.

\section{$\mathrm{XV}$.}

„Samo očajanje, strava noći, obuzetost nečim i gorak okus duše.

Iz ovog grada nema izlaza,

ovaj grad je ko prokleta avlija.

Opasan visokim zidinama mraka, snažnim tvrđama moćne gluposti i oštrim bodljama uskog horizonta.

Znanje traži izlaz, al ono je zaludu, u duši mračnoj podzemlje se stvara,

\footnotetext{
${ }^{163}$ Dubravka Oraić Tolić navodi dvije vrste vakantnih (praznih) citata - pseudocitate i paracitate. „U pseudocitatima postoji realni PT, ali je citatni dodir između vlastitoga i tuđega teksta, između C i PT - lažan. U paracitatima nema nikakva realnoga PT s kojim bi se suodnosio T, lažni su i C i PT.“ (1990: 18) Napomena o kraticama (D. M. L.), prema Oraić Tolić (1990: 228): PT - prototekst, predtekst, podtekst; T - tekst; C- citat.
} 
haraju zločeste osvetničke bande,

kopnu na žezi bola posljednje kapi smisla.

Glava natekla od gustoće mraka,

a srce pusta golet krša.

Iz ovog grada nema izlaza

ovaj grad je ko prokleta avlija.“

(GOD: 151)

Navedena se pjesma može promatrati kao ostvarenje dijaloškoga odnosa s „Odom Dubrovniku“164, pjesmom čiji je autor prvi hrvatski poeta laureatus - humanist Ilija Crijević. Oda predstavlja pjesnički oblik kojim se izražava javna hvala, a prevladavaju uzvišeni osjećaji i svečano raspoloženje. S tim u skladu, prvi stihovi Crijevićeve ode ${ }^{165}$ patetičnim zanosom hvale Dubrovnik (,zjenico moja“, ,,potomče pravi““, „,naselje časno“, „tebi, najbolji“.... ${ }^{166}$. Uzvišena atmosfera Crijevićeve pjesme prekida se u trećoj strofi, kada lirski subjekt iznosi autobiografske elemente - nezadovoljstvo položajem vojnoga zapovjednika u stonskoj tvrđavi $^{167}$. Ovakva promjena raspoloženja, prekidanje svečanoga tona, ovoj odi priskrbljuje efekt začudnosti.

Vickova XV. pjesma naglašava zatvorenost Dubrovnika (za Dubrovnik koristi sintagmu „ovaj $\left.\operatorname{grad}^{\circ}\right)$, bezizlaznost za pojedince koje guše uski horizonti i moć gluposti. Stvarne stonske zidine i tvrđe od kamena iz Crijevićeve ode (,zapovjednik u groznoj tvrđi““, „zatočen pod žarkim suncem sred kužna zraka, u kugi dvomorskog Stona““ ${ }^{168}$ doživljavaju u Vickovoj pjesmi metamorfozu od fizičkog k metafizičkom.

U Šehovićevu romanu riječ je o „zidinama mraka“ i „tvrđama moćne gluposti“, čime se dočarava duhovno stanje pojedinca koji ne želi pristati na prosječnost te umjetničke, ali i ljudske kompromise koje mu nudi vladajući sustav.Vicko, ne pristajući kao pjesnik, ali i svećenik, na dogovorene poetske teme i forme, prototip je takvoga pojedinca.

Vidljivo je kako je Vickov odnos prema Dubrovniku u suprotnosti s Crijevićevom pjesničkom prezentacijom Dubrovnika, a istovjetan Crijevićevu odnosu prema Stonu.

\footnotetext{
${ }^{164}$ Ovu intertekstualnu relaciju spominje Irena Lukšić u pogovoru romana riječima: „Kao primjer mogli bismo navesti pjesmu 'XV.' i njenog dijaloškog (u ironijskom modusu) partnera u Odi Dubrovniku Ilije Crijevića“" (171).

${ }^{165}$ Tekst ode vidi u: Crijević, Ilija. 1969. Oda Dubrovniku. U: Hrvatski latinisti (knjiga 2, PSHK), ur. V. Gortan i V. Vratović, str. 384. Zagreb: Matica hrvatska.

${ }^{166} \mathrm{~V}$. prethodnu fusnotu.

${ }^{167}$ Godine 1495. Crijević je nekoliko mjeseci bio kastelan u Stonu. (v. Gortan - Vratović 1969: 377 - 378)

${ }^{168}$ V. fusnotu br. 164.
} 
Crijevićev Ston i Vickov Dubrovnik obilježeni su etiketama zatvorenosti i bezizlaznosti, u prvom slučaju kao fizičkih kategorija, a u drugom slučaju s pomakom prema duhovnim kategorijama.

Može se zaključiti kako se Vickova XV. pjesma ironijski ne naslanja na Crijevićevu odu u cijelosti, već samo na njezin prvi dio (prve dvije strofe), dok se, s druge strane, približava osuđujućem tonu drugoga dijela ode. U svakom slučaju među pjesmama je postignut upravo dijaloški odnos, u kojem jedna pjesma osvjetljava drugu.

S obzirom da u sklopu Vickove pjesme Šehović nigdje ne spominje Crijevića ni njegovu „Odu Dubrovniku“, ovakva je intertekstualna veza ostvarena aluzijom i time predana u ruke širini i dubini čitateljeve književne naobrazbe i interesa.

Stih „ovaj grad je ko prokleta avlija“, također iz XV. Vickove pjesme, gotovo s lakoćom intertekstualno odvodi do Proklete avlije Ive Andrića ${ }^{169}$.

Iako ni u ovom slučaju nije prisutna vanjska signalizacija (npr. navodni znakovi, drugi tip slova), pretpostavka je da će sintagmu ,prokleta avlija“ veći broj čitatelja (u odnosu na Crijevićevu „Odu Dubrovniku“) prepoznati kao naslov istoimenoga djela, čak i ako se ne sjete (odmah) njegova autora.

Andrićeva ,prokleta avlija“،, kojom vlada groteskni Karađoz, ozloglašeni je carigradski zatvor u koji su smješteni ne samo oni koji su skrenuli s ,pravoga puta“ u pravnome smislu, nego i mnogi nevini, kao žrtve određenih vladajućih mišljenja. Najšire gledajući, Andrić je ispripovijedao kraći roman o mehanizmu totalitarističkih sustava te na taj način uputio umjetničku kritiku takvoga oblika vlasti.

Za relaciju s Vickovom pjesmom značajan je Andrićev lik Ćamil. Ovaj nježni mladić dospijeva u zatvor jer su predstvnici vlasti u njegovu bavljenju poviješću vidjeli akt pobune protiv struktura vlasti. Strpan među carigradskim zidinama, Ćamil je stiješnjen i duhovnim zidinama.

Vickov je pjesnički položaj istovjetan Ćamilovu povjesničarskome radu: poezija mu je prozvana demonskom jer se u njoj, kako kaže biskupski ordinarijat, „omalovažavaju osnovni temelji Kristove nauke; u njoj nema Božje nade ni ufanja, nego je sve prepušteno demonskoj sili koja vlada na zemlji“ (GOD: 140).

Vickove su pjesme postale najčvršći dokaz njegove krivnje. Uslijed dogmatskog iščitavanja njegove poezije Vicko je optužen za antikršćanske i heretičke poglede. Osuđen je na pritvor, a

${ }^{169}$ V. Andrić, Ivo. 2014. Prokleta avlija. Podgorica: Nova knjiga. 
pjesme su mu oduzete, zaplijenjene. Savjetovano mu je da se odrekne svećeničkoga poziva i prepusti službi koja bi bolje odgovarala njegovu „slobodnu“ duhu.

I Ćamil i Vicko kažnjeni su jer razmišljaju i djeluju drukčije od zadanih okvira, zato što se ne daju smjestiti u pretpostavljene kalupe. Njihova različitost, izdvajanje iz mase, „stršenje“ predstavlja opasnost za određeni poredak vlasti. Riječ je o osuđenicima bez konkretne krivice. Osudila ih je njihova vjera u slobodu mišljenja, govorenja, pisanja... Za ove su likove „avlija“ i ,grad“ jednako prokleti kao i Ston za lirski subjekt u Crijevićevoj odi.

Izraz „cvjetovi zla“ prizivaju slavnu Baudelaireovu pjesničku zbirku:

„U vrtu duha samo gnjev raste

ko žilavi korov buja i cvjeta u sivo.

Svud okolo su sivi cvjetovi zla.“(GOD: 140)

Koristeći spomenuti izraz kao dio Vickova stiha, Šehović dodatno podcrtava ne samo Vickov pesimističan svjetonazor, već i položaj njegovih pjesama u javnosti.

Poznata je sudbina Baudelaireove zbirke iz 1857. godine: osuđena je, i to ne samo na nekoj simboličnoj razini, već u sklopu sudskoga procesa ${ }^{170}$.

U Gorkom okusu duše crkvena vlast pritvara Vicka upravo zbog njegove zbirke pjesama, uz objašnjenje da jedan svećenik ne bi trebao pisati o razočaranosti, bezizlaznosti, očajanju i rezignaciji.

Posljednja (XXV) pjesma Vickove zbirke u svome finalu priziva Danteov Pakao:

„Oprosti mi, Bože, što zaboravih majku

i prezreh zemlju gdje očev mi je dom.

Oprosti mi što ne želim sjećati se nikog

i ničeg

i što sam na đubrište bacio svoje uskisle nade.

Oprosti mi, Bože, mržnju, prezrenje, nehaj i oholost,

jer ja sam očajan i ogorčen,

jer ja sam prognao sebe iz predvorja pakla

${ }^{170}$ V. predgovor Višnje Machiedo u: Baudelaire, Charles. 1996. Cvjetovi zla / Spleen Pariza. Zagreb: SysPrint. 
u njegov najstrašniji krug.

Oprosti mi, Bože,

oprosti mi

oprosti.“(GOD: 156)

Prema Danteu, u predvorju pakla borave mlitavci i kukavice, a u „najstrašnijemu“ (devetom) krugu muče se izdajice. Kao najgori među njima obilježeni su izdajice dobročinitelja - Juda, Brut i Kasije. $^{171}$

Moglo bi se pretpostaviti kako ovom analogijom Šehović protagonista Vicka vodi od položaja „mlitavca“, onoga čije mišljenje i djelovanje u početku fabularnoga razvoja još nije jasno određeno, do javnoga položaja izdajice - Jude s obzirom da je izdao/zaboravio/prezreo onaj način života koji su u njega usađivali njegovi dobročinitelji.

Motiv nastrašnijega kruga pakla semantički se nadovezuje na gore spomenute motive zidina mraka, grada bez izlaza, proklete avlije...

Šehović tako Vickovu sudbinu kao prototip sudbine onih koji različito misle, društveno „stršs“", izgrađuje posezanjem u već ukorijenjene, čitatelju manje ili više prepoznatljive kreacije iz hrvatske i svjetske književne baštine. Međutim, između Šehovićeva romana i spomenutih segmenata književne baštine ne ostvaruje se jednosmjeran proces, u smislu zamke izvora ili utjecaja, na koju upozoravaju Kristeva i Barthes. Riječ je o suodnosu, međusobnom dijalogu tekstova, gdje jedan osvjetljava drugoga/druge na način da dolazi do nove artikulacije (Kristeva).

Intertekstualnih je žarišta mnogo više nego što je to upravo prezentirano. Pozornost je usredotočena na ona mjesta koja bi intertekstualno bila zamjetljiva ,prosječnome“ čitatelju, s obzirom da Andrićeva Prokleta avlija, Danteova Božanstvena komedija i Baudelaireovi Cvjetovi zla predstavljaju stalno mjesto (srednjo)školskoga gradiva. Jedino odnos s Crijevićevom „Odom Dubrovniku“ pretpostavlja istančanije zanimanje za područje književnosti.

Očito je koliko je djelatnost čitanja važna za tekstualnu praksu. Značenje se ne može direktno ugraditi u tekst procesom pisanja; ono nastaje za vrijeme čitanja i ovisi o brojnim karakteristikama čitanja/čitatelja. Šehović je mogao pretpostavljati idealnoga čitatelja, ali ta zamisao u čitateljskoj praksi, a time i u daljnjem ,životu“ teksta, ne znači puno.

\footnotetext{
${ }^{171}$ Prema Alighieri, Dante. 2004. Božanstvena komedija. Zagreb: Globus media.
} 
Roland Barthes ističe kako jedinstvo teksta ne leži u njegovu porijeklu, nego u njegovu odredištu, čitatelju:

„Čitatelj je prostor na kojemu su svi citati koji čine pisanje zapisani.“(1999a: 201)

Teoretičarka Renate Lachmann, na tom tragu, upravo intertekstualnost vidi kao modus konstitucije smisla teksta:

„Budući da se konstitucija smisla teksta može ugraditi tek u odnosu na tuđi tekst, ona gubi svoj statički karakter i može se zamisliti kao proces. To znači da se sam tekst konstituira intertekstualnim procesom, koji apsorbira i prerađuje misaone obrasce drugih tekstova, omogućujući komunikaciju koja nikada ne zahtijeva jednosmislenu suglasnost.“"(1988: 79)

I u tekstovima koji ne signaliziraju eksplicitno intertekstualne veze (ime i prezime autora, naziv djela), čemu je primjer i ovaj Šehovićev roman, čitatelji će uspostavljati određene intertekstualne odnose. Time se pokazuje kako je čitanje proces u kojem je nemoguće čitati samo jedan tekst. Čitajući jedan, prizivamo/čitamo mnoge. Tekstovi odražavaju uvijek (i) druge tekstove, pokazujući time da su i pisanje i čitanje djelatnosti u kojima je nemoguće okrenuti glavu od dosadašnjeg korpusa (književne) kulture.

Odnos među tekstovima na ovaj se način postavlja kao privilegiran u uporedbi s odnosom zbilja - tekst.

Uzevši u obzir odabrane primjere intertekstualnih relacija, može se zaključiti kako termin vakantni (prazni) citat (Oraić Tolić) lakše funkcionira u teorijskome nego praktičnome okruženju. U književnoj praksi nemoguće je postići stvaranje ex nihilo.

Vickova pjesnička zbirka, u ulozi testimonijalnoga dokumenta unutar Šehovićeva romana Gorak okus duše, percipirana kao paracitat, odnosno ,autorska mistifikacija“ (Irena Lukšić) bez oslonca u drugim tekstovima, zapravo ukazuje na čitav niz intertekstualnih spojnica kojima je „,ispunjen“ ovaj prazni citat. 


\subsubsection{Odnos među testimonijalnim zapisima unutar Šehovićevih povijesnih romana}

U cilju izravnog nadovezivanja na prethodno potpoglavlje, prvo će se razmotriti odnos među testimonijalnim zapisima unutar romana Gorak okus duše.

Što se tiče aluzija pjesama iz Vickove pjesničke zbirke na epizode proznoga dijela ovog romana ${ }^{172}$, mogu se istaknuti neke spojnice, iz kojih je vidljiv upravo dijaloški odnos između proznoga i stihovanoga dijela romana.

Tako se prva Vickova pjesma u zbirci referira na scenu Vincencova posjeta padre Josipu.

Josipov gubitak vjere u ljude isprva je potpuno neshvatljiv Vincencu, ali pred kraj života i on gubi nadu. I Vicku je iskustvo robovanja pobudilo sumnju u sve, obuzeo ga je osjećaj beznadnosti koji ga više nije napuštao ${ }^{173}$.

Četvrta pjesma polemizira s Vincencovim stavovima o zatvorenosti i nefleksibilnosti mišljenja. Nasuprot njemu, Vicko ističe težnju da se prelaze granice i ,putuje“ intelektualno, što je i jedan od provodnih motiva ovoga romana. ${ }^{174}$

Rekvijemska atmosfera prožima petu pjesmu: odnosi se na Vincenca kao „posljednjeg borca vojske čovječanstva“ (GOD: 148), a uklapa se u epizodu njegove smrti.

Govoreći o „vremenu prizemljivanja“ (GOD: 150), dvanaesta se pjesma reflektira na trenutak Vickova odustajanja od onih ideala koje je u njega dugo pokušavao ukorijeniti ujak Vincenco. Dvadeset i druga pjesma zbirke aludira na Vickov razgovor s pjesnikom Ivanom Gučetićem o vladavini osrednjosti ${ }^{175}$ i onima koji se u takve kalupe ne uklapaju.

Posljednja, dvadeset i peta pjesma, mogla bi funkcionirati kao Vickovo oproštajno pismo u kojem traži oprost od Boga, čime se izravno nadovezuje na pretposljednje poglavlje romana u kojem je opisan čin Vickova samoubojstva.

Osim prikazanoga suodnosa proznog i stihovanog dijela romana, u Gorkom okusu duše vidljivo je lančano oslanjanje zapisa na zapis / usmeno kazivanje: potpisnik Predgovora predstavljen kao Autor (a koji zapravo u romanu funkcionira kao ekstradijegetički heterodijegetički pripovjedač) poziva se na Kroniku fra Mavra S.; fra Mavro S. oslanja se na

\footnotetext{
${ }^{172}$ Ovakve poveznice konstatira i Irena Lukšić u predgovoru romana Gorak okus duše.

173 „Sad, kad curi nektar znanja / iz zgusnuta iskustva i uspomena, / kad vidim mnogo toga / iza granica stvari, / prestao sam osjećati / opojni miris budućnosti. / I nemam volje za nadanja, / nemam snage za čekanja, /nemam smisla za ljubav..."(GOD: 146)

174 „Treba što dublje zaroniti u svijet, / tamo gdje je potpuna tama, (...) / Treba što dublje preći granice, / u bludnoj želji za znanjem i smislom, / treba se odreći kljastih spoznaja / i ići, ići, strasno putovati.“ (GOD: 147) 175 „Umjesto snažna isušujućeg Sunca / nad žabokrečinom se ustoličila / blijeda, mala zvijezda osrednjosti.““ (GOD: 154)
} 
Vickove zapise, a Vickovi zapisi nastali su na temelju Vincencova predsmrtnoga usmenog kazivanja.

Pozivanje na fra Mavrov rukopis izvan predgovornih bilježaka, dakle u okviru daljnjeg fabularnog tijeka romana, uvijek je ostvareno u odnosu prema Vickovu svjedočenju.

U tome je kontekstu ponegdje vidljivo i pripovjedačevo isticanje međusobno suprotstavljenih informacija iz testimonijalnih iskaza (prvi navod u daljnjem tekstu) ili komentar na tuđi iskaz, pri čemu do izražaja dolazi i stav pripovjedača prema iskazanome (preostala dva navoda):

„U Kronici fra Mavra S., pa i raspoloživim dokumentima iz 16. st., ne postoji nikakvih dokaza da je fra Vincenco pripadao nekoj političkoj tajnoj organizaciji. Ali,Vickovi zapisi govore da je fra Vincenco po nalogu mladog Tuberonova rođaka pošao za gvardijana u samostan na turskoj granici gdje je, po svemu sudeći, našao pravi smisao svoga života. Odmah je supostavio tajnu vezu s mletačkim uskocima..." (GOD: 17)

„I kako će to Mavro S. u svojoj Kronici zabilježiti, dum Vicko je držao lijepe, ali čudne propovijedi, u kojima je često, govoreći o mukama svetaca, govorio zapravo o svom ujaku fra Vincencu, što na žalost 'neuki puk nije uspio razumjeti'. Poneke od tih propovijedi zapisao je učeni Mavro S. po sjećanjima starijih suvremenika.“(GOD: 114)

„Učeni Mavro S. zamjera Vicku što odgovore na svoja pitanja nije potražio u Svetom pismu 'gdje je sve jasno kazano', ali i sasvim točno uočava neraskidivu vezanost Vickove poezije za sudbinu svoga ujaka. U tom je Mavro S. sasvim u pravu, jer je vrhovni motiv Vickove poezije patnja, a ujak Vincenco je bio za njega primjer sposobnosti paćenja...“(GOD: 117)

Reprezentativan primjer suodnosa pisanih iskaza svjedoka u Oslobađanju đavola predstavlja komunikacijski akt između sjećanja suca Andre na dubrovački potres, iznesenih u kronici Zapisi o paklu, i fra Mavrovih naknadnih intervencija u Andrine bilješke (komentari na marginama rukopisa, prepravljanja, nadopisivanja).

„Činjenice nedvojbeno upućuju da je fra Mavro prvi put rukopis čitao tek poslije Andrine smrti. Sudeći po marginama, pjesnik je pažljivo analizirao cijeli tekst, 
ispisavši bezbrojne opaske. Mnoge dijelove je očito on prekrižio, stavivši sa strane znak za izbacivanje. Uglavnom su to ona mjesta u kojima Andro veliča Mavrine zasluge u spašavanju domovine poslije tragičnog potresa. Na svim mjestima, pored citiranih latinskih stihova, fra Mavro je stavio ime Stjepana Gradića. Najviše primjedbi ispisano je na marginama drugog dijela rukopisa, koji je sudac Andro počeo stihovima iz Mavrine poeme 'Oslobađanje đavola': 'NE PITAJTE ME OTKUD ZNAM ŠTO JE PAKAO, JER ŽIVIH U NJEMU!'‘ (OĐ: 169)

Istovjetan obrazac pisanja bilježaka po marginama nečijega teksta, čime se ostvaruje određen simbiotski odnos vlastite i tuđe riječi, vidljiv je u Begovini, trećem romanu sage o Ilijasbegovićima.

Riječ je o Ilijas-begovim komentarima knjige svoga prijatelja Ivana Lovrenovića, koja se sastojala od dva dijela - Prisjećanja sa Soče i Piave i Muslimani i bosanski franjevci, te knjige sina Enver-bega Ko smo to mi muslimani u BiH:

„Tako sam ja ${ }^{176}$, niz godina poslije, tek u svojoj zrelijoj dobi imao priliku shvatiti što je dedo na praznim stranicama očeve knjige i na njezinim marginama zapisao i zbog čega je bila onolika frka i svađa.

Na praznim poleđinama nekoliko prvih stranica, dedo je, kao i u knjizi fra Ivana, bez suvišna zaobilaženja započeo: 'Sine, krivo misliš o meni...' (...). Po marginama knjige, kraj olovkom podvučenih redova, slijede dedove opaske: 'Nama je vazda bilo da bijasmo svačija pastorčad...' (...).

Svoje stavove i uvjerenja dedo Ilijas-beg je mnogo jasnije izrazio na praznim stranicama i marginama fra Ivanove knjige 'Zapisi sa Soče i Piave'. (...) Više od 'poštenog prikazivanja' bošnjačke golgote na Soči i Piavi te nepravednog suđenja 'pravednicima' privukao je dedovu pažnju drugi dio knjige 'Franjevci i bosanski muslimani', pa je pored čestog podvlačenja teksta i zapisa na marginama, ispisao tintom i čitljivim rukopisom nekoliko dodatnih listova papira.“ (I: 477 - 478)

Osim prikazanih komentara po marginama, i Ilijasbegovići su obilježeni uzorkom međusobnog oslanjanja iskaza svjedočenja, kakav je, u kontekstu Šehovićeve romaneskne poetike, vidljiv od Gorkoga okusa duše.

\footnotetext{
${ }^{176}$ Kako je ranije kazano, u ovome dijelu Ilijasbegovića kao narator i fokalizator nastupa mladi Ilijas (unuk Ilijas-bega, odnosno sin Enver-bega).
} 
U tome smislu može se uputiti na oblikovanje sudbine Hasan-bega kao protagonista Inšallaha putem dijaloške komunikacije Enes-begova kazivanja i Sultanijinih zapisa: Enes-beg u svoje usmeno svjedočenje redovito uključuje Sultanijine rečenice, kao i davne fra Matijine riječi ${ }^{177}$, dok se Sultanija u svojim zapisima nerijetko referira na neke Enesove priče.

I Prokleta ergela, posljednji Šehovićev povijesni roman, demonstrira situaciju ulančanosti testimonijalnih zapisa (fra Ilija - fra Andrija - fra Marko Anđelović).

Fra Andrija tako u svoju knjigu, koja se bavi životom i djelom njegova prethodnika i uzora fra Ilije, ugrađuje Ilijine usmene iskaze te rečenice iz njegove knjige. Andrijin nasljednik fra Marko svoje zapise, između ostaloga, temelji i na Andrijinim svjedočenjima, pa tako, primjerice,

„u svome rukopisu navodi zadnju rečenicu fra Andrijinih zapisa: 'Htio sam napisati, jer toliko za tim žudjeh, ali nisam niti ću ikad to učiniti. Dobro je i potrebno piscu da sam prođe golgotu kako bi je što vjernije opisao (...)'‘ (PE: 166 - 167).

U Šehovićevim se povijesnim romanima, osim uobičajenoga slučaja upućivanja na imenovane svjedoke i ,provjerljive“ dokumente (kojima se navodi naziv, sadržaj, vrijeme nastanka i sl.), mogu zamijetiti općenita pozivanja na usmene ili pisane iskaze koji se ne mogu ovjeriti, budući da im je podrijetlo nepoznato.

I na takvim mjestima vidljiva je dijaloška forma iskaza, najčešće u vidu sukobljenosti tumačenja određenih prošlih događaja. U tome su kontekstu reprezentativni primjeri međusobnoga nepoklapanja znanstvenog pristupa prošlim događajima i testimonijalnih iskaza sudionika stanovitih povijesnih epizoda u romanu Oslobađanje đavola. ${ }^{178}$ Tako znanost faktografski, s naglaskom na brojčanim podacima, nastoji nepristrano zahvatiti velike potrese u Dubrovniku kao prirodnu pojavu:

„Znanost bilježi da su u velikoj trešnji u Dubrovniku, koja se dogodila 6. travnja 1667. godine, prethodila dva katastrofalna potresa nadprosječne jačine. O davnom, iz 367. godine postoji vrlo malo šturih podataka, dok o onom koji se dogodio 11. svibnja

\footnotetext{
${ }^{177}$ Fra Matija - svjedok/zapisivač sudbine Ilijas-bega, kapetana trebinjskoga, protagonista prvoga romana ciklusa o Ilijasbegovićima.

${ }^{178}$ Odnos znanstvenih i „narodnih“ iskaza iskaza vidljiv je, primjerice, i u Gorkom okusu duše (tumačenje podrijetla imena sela Bezbozi).
} 
1520. ima niz raznovrsnih i uvjerljivih dokaza. (...) Kako pisani dokumenti svjedoče, broj mrtvih nije bio velik...“(OĐ: 7)

Narodna je percepcija gore spomenutoga potresa iz 1520. godine potresa uokvirena kršćanskom ideologijom, odnosno potres je tumačen biblijskom slikom oslobađanja zazidanoga đavola. Zbog toga su izjave svjedoka izrazito figurativne te ispunjene apokaliptičnim raspoloženjem:

„U izjavama sudionika prevladavaju slike strave i užasa; o brdu Srđu poviše grada, koji se 'ljuljao kao jarbol na brodu' i s kojega su se kotrljale 'prema gradu ogromne stijene', o 'raspuklinama ispod Brgata, kroz koje su provirivali đavolji rozi iz podzemlja'...“(OĐ: 7)

Na temelju prethodno iznesenih primjera iz Šehovićevih povijesnih romana vidljivo je koliko ovaj književnik naglasak stavlja na komunikaciju među dokumentima, posebno onim dokumentima koji predstavljaju iskaze svjedoka određenih događaja.

Intertekstualnim referencama (putem citata i aluzija), ali i metatekstualnim te paratekstualnim odnosima, Šehovićevi romani upućuju na različite aspekte transtekstualnosti (Genette) ${ }^{179}$ kao generalnoga obilježja svojstvenoga svakome tekstu.

Ne samo na vanjskoj razini (primjer odnosa testimonijalnoga zapisa i tekstova književne baštine) ${ }^{180}$, već i na unutarnjoj (odnos među testimonijalnim zapisima unutar romana) demonstrira se, figurativno rečeno, načelo nemogućnosti pisanja po praznome papiru, s obzirom da „možda i ne postoji konačno brisanje, takvo ukidanje znaka koje se ne bi moglo poništiti lektirom, recollectio, rekonstrukcijom“ (Lachmann 2002: 220).

Ovakvim pristupom svako pisanje predstavlja palimpsestički čin, čime nam je omogućeno „spoznati u sadašnjemu tragove prošlosti ili u prošlome tragove sadašnjosti“ (Lachmann 2002: 219).

Iako je s jedne strane svjedočenje nužno vezano za individulano osjetilno, doživljajno i spoznajno iskustvo nekog događaja, a time i za ono što bi se najšire rečeno moglo nazvati zbiljom, s druge strane, svjedočenje do adresata dolazi (ili se barem pokušava prenijeti) posredstvom jezika $^{181}$.

\footnotetext{
${ }^{179} \mathrm{O}$ Genettovoj problematizaciji transtekstualnih odnosa vidi u fusnoti pod rednim brojem 158.

${ }^{180} \mathrm{~V}$. prethodno potpoglavlje.

${ }^{181}$ V. poglavlje „Svjedok, svjedočenje: teorijska kontekstualizacija“.
} 
Upravo ova tekstualna priroda svjedočenja dolazi do izražaja u Šehovićevim romanima, gdje je uobičajeni interes za odnos zbilja - tekst redovito pomaknut na postmodernističku preokupaciju odnosom tekst - tekst.

Tako se u Šehovićevim povijesnim romanima tekstovi svjedočenja prvenstveno ponašaju kao tekstovi, tvoreći na taj način, uslijed svoje nužne upućenosti na druge tekstove, svojevrstan testimonijalni palimpsest. 


\section{SVJEDOČENJE I TRAUMA}

\subsection{Koordinate traumatskoga iskustva}

Trauma je jedan od termina koji se, ne samo kolokvijalno, nego i u znanstvenome prostoru nerijetko upotrebljava bez posezanja za nekim preciznijim definicijskim ovjerama, kao jedan od onih termina čije se značenje samo po sebi razumije.

Ni ovaj rad na određenim mjestima nije uspio izbjeći upravo spomenutu paradigmu pristupa traumatskom. Ipak, budući da je fokus interesa na traumu postavljen tek u ovome, petome poglavlju rada, nužno je, tom prilikom, inicijalno okvirno upućivanje na koordinate traumatskoga iskustva.

Prilikom zahvaćanja same „prirode“ traumatskoga od značajnoga su interesa zapažanja neurologa i utemeljitelja psihoanalize Sigmunda Freuda te teoretičarke traume Cathy Caruth. Caruth u svome djelu Unclaimed experience: Trauma, Narrative, and History slijedi, interpretira i komentira temeljne Freudove postavke o traumi, posebno one iznesene u eseju $S$ onu stranu načela ugode.

Etimološki gledajući, riječ trauma vuče podrijetlo iz grčkoga jezika, gdje je označavala ranu, ozljedu na tijelu. ${ }^{182}$ Kasnije se u psihijatrijskoj literaturi ovaj termin koristio ne kao ozljeda na tijelu nego u duši/umu/sjećanju/ „upon the mind“ (Caruth 1996: 3).

Koristeći sintagmu traumatska neuroza pri bavljenju traumatskim, Freud naglašava distinkciju traumatske neuroze i teorije šoka (budući da se ove pojave znaju nerijetko zamjenjivati): šok je uvijek vezan za izravno oštećenje nervnoga sustava, dok je kod traume riječ o vanjskim uzbuđenjima koja su toliko jaka da probijaju „sloj“ koji štiti duševni organ od podražaja (1986: 157 - 159), dakle, kako je gore napomenuto, riječ je o „rani na duši“, a ne na tijelu.

Kad je riječ o vanjskim uzbuđenjima koja dovode do traumatskoga, ne postoji određeni popis tih uzbuđenja, odnosno popis događaja koji izravno dovode do traumatskoga odgovora, već, prema Freudu, „glavni uzrok (traumatske neuroze, D. M. L.) leži u momentu iznenađenja, prepasti“ (1986: 140), pri čemu dolazi do spomenutog probijanja zaštitnog omotača kod subjekta. Dakle, Freud „odbacuje čvrstu uzročno-posljedičnu vezu između traume i događaja koji je pobuđuje“ (Mijatović 2009: 150).

\footnotetext{
${ }^{182}$ Trauma grč. (trauma, 2. -atos - rana, ozljeda) (Rječnik stranih riječi 2007: 1370).
} 
Na tragu upravo istaknutoga, ne može se tvrditi da protagonisti-svjedoci u povijesnim romanima Feđe Šehovića prolaze traumatsko iskustvo samo na temelju događaja u kojima sudjeluju i koji na njima ostavljaju stanovit trag, bez obzira koliko ti događaji po određenim parametrima bili percipirani kao tragični, nasilni, katastrofični...

Pritvaranje i psihofizičko mučenje svećenikaVincenca i nećaka mu Vicka (Gorak okus duše), kao i fra Ilije i fra Andrije (Prokleta ergela); višestruka logorska iskustva Luke i Pepa (Uvod u tvrđavu); nasilni i tragični prizori (osude, potjere, zatočeništvo) u kojima na različitim razinama stradavaju članovi obiteljskoga stabla Ilijasbegovića u istoimenoj romanesknoj sagi; potres katastrofičnih razmjera te obiteljski gubitci (Oslobađanje đavola); promišljanja o samoubojstvu (Luko iz Uvoda u tvrđavu) i samoubojstva (Vicko iz Gorkoga okusa duše i Ilijas u petome romanu ciklusa Ilijasbegovići); stradavanje svih Šehovićevih protagonistasvjedoka u vidu javne osude i društvenoga izopćenja, otpadništva - sve navedeno još uvijek ne jamči olako korištenje traumatskoga diskursa, ako se pozovemo na spomenuto ukidanje načela kauzalnosti između događaja i traume (Freud).

Dakle, nije sam događaj kao takav preduvjet traumatskoga, već njegova refleksija na (ne)svjesno pojedinca koji na neki način postaje „fiksiran za traumu“ (Freud 1986: 140). Traumatsko se temelji na „prisili ponavljanja“, na repetitivnosti onoga što se ne može dozvati u svjesnost, već se najčešće pojavljuje putem noćnih mora, flashbackova te srodnih ponavljajućih fenomena (Freud 1986: 146 - 157; Caruth 1996: 91). Ono što se „vraća“ žrtvi nije sam traumatski događaj nego fenomen da to nasilje nije spoznato (Caruth 1996: 6).

Spomenuti odnos svjesnosti - nesvjesnosti, odnosno znanja - neznanja, ne predstavlja problemsku sastavnicu Šehovićevih povijesnih romana u kontekstu odnosa lika i (traumatskoga) događaja. Iako gore popisani događaji (zatvori, logori, progoni...) predstavljaju ključne i sudbonosne događaje u životima Šehovićevih protagonista, u smislu događaja koji oblikuju prvenstveno njihov stav prema ideološkim strukturama, naratološka izgradnja ovih likova upućuje na svjesnost onoga što im se dogodilo, dakle ne radi se o nečemu što je potisnuto pa repetitivno izbija tražeći put do svijesti pojedinca.

Iz navedenoga se dade zaključiti da se Šehović u svojim romanima uglavnom ne bavi traumom na njezinoj individualnoj, kliničkoj razini, već ga prvenstveno zanima trauma na društvenoj razini i povijesnome kontekstu: odnos traumatskoga i povijesnoga.

Traumatsko je u tome smislu usko povezano s konceptom povijesti u Šehovićevim romanima - već spomenutome cikličnom doživljaju povijesti kao vječnom vraćanju istoga, suprotstavljenom ideji linearnosti i progresa (prisutnoj u tradicionalnom povijesnom romanu). 
Dok događaji u okviru linearne percepcije povijesti posjeduju svoje mjesto na vremenskoj liniji prošlost - sadašnjost - budućnost, pri čemu budućnost može biti različita od prošlosti (povijest kao učiteljica), u cikličnom doživljaju povijesti ukidaju se te uobičajene vremenske kategorije, ne otvara se mogućnost za novo i drugačije, već vlada repeticija istoga, a time i jedno vječno, ,sada“.

Upravo je iz ovoga vidljiva poveznica ciklične vizije povijesnoga te fenomena traume „trauma je događaj koji nema početka, kraja, nema prije, tijekom ili nakon“ (Laub 1992: 69), u slučaju traume ,prošlost je uvijek prisutna“ (St. Just 2012: 229).

Trauma se, pak, u suvremenim teorijama promatra i kao „događaj koji se ne uklapa u zamisao o kontinuitetu povijesti, ne može (se) objasniti ničim do tada poznatim pa se proglašava graničnim jer prelama povijest na vrijeme prije i vrijeme nakon njega“ (Mijatović 2009: 145).

Na tom tragu James Berger uvodi pojam postapokalipse u govor o traumatskom, upućujući da „kultura na traumu odgovara tako što je zaodijeva u lik apokalipse kako bi se mogao prihvatiti nepodnošljivi užas povijesnoga događaja“ (isto: 145).

“Događaj se prebacuje u ispunjenje predviđanja, ostvarenje proročanstva, čime se stvara naknadna pripremljenost na sam događaj. Prijelomni događaj nije nešto što se iznenada dogodilo u prošlosti koja se nastoji potisnuti, već je on ono što će se dogoditi u budućnosti, kao oblik njezinoga ispunjenja. Ovim postapokaliptičkim ugrađivanjem dimenzije budućnosti u prošlost razvija se naknadna pripremljenost na događaj.“ (isto: 146)

Ovakav pristup traumatskome neizbježno je dovesti u vezu s ranije spomenutim Freudovim upozorenjem kako je trauma vezana za iznenadnost, neočekivanost, nepripremljenost na događaj. Iz toga razloga, tvrdi Freud, strepnja nas štiti od prepasti, a time i od traumatskoga iskustva (1986: 140).

Iniciranje strepnje (a time i pokušaj izbjegavanja efekta traumatskoga) modusom apokalipse prisutno je u Šehovićevu romanu Oslobađanje đavola, u kojem se naslovna sintagma odnosi na potres katastrofičnih razmjera koji je zahvatio Dubrovnik, tumačen $u$ narodu kao kazna za ljudske grijehe (biblijski motiv đavla koji će biti odvezan ). Fabularni tijek ovoga romana realiziran je uokvirenom, cikličnom kompozicijom budući da su početak i kraj romana vezani za koban datum u okviru dubrovačke povijesti - 6. travnja 1667. 
godine, s tim da posljednje poglavlje romana funkcionira kao apendiks čiji su sadržaj različiti izvještaji svjedoka potresa.

Središnji dio romana tako je ispunjen događajima koji su prethodili velikom dubrovačkom potresu, a vremenski obuhvaća otprilike šest mjeseci prije potresa.

U tome smislu važna su predviđanja jednoga od likova. Ser Luciano (Luko) Mathei de Pozza, ugledni dubrovački fizičar poznat po svom isključivom kršćanskom svjetonazoru ${ }^{183}$, zauzima u romanu poziciju zlogukog proroka koji upozorava Dubrovčane na katastrofalne posljedice do kojih će dovesti njihovi nemoralni životi.

Usmenim iskazima te pisanom raspravom, koja je nastala kao rezultat njegova zanimanja za potrese od 1622. godine, Luko predskazuje ne samo spomenuti potres, nego i mnoge druge:

„U svojoj kraćoj raspravi 'Aut nihil aut veritas' L. M. De Pozza proriče buduće potrese u gradu Dubrovniku i najbližoj okolici: 1632., 1657., 1667., 1689., 1782., 1800., 1821., 1838., 1851., 1876., 1898., 1902., 1925., 1939., 1961., 1979., 1989., 1993., 1999., 2010., 2018. Mjesece nije označavao, a godine za koje misli da će se dogoditi katastrofalni potres, dva puta je podvukao. To su: 1667. i 2018.“ (OĐ: 12)

Potvrdu obistinjenja Lukinih riječi Dubrovčani prepoznaju u mnogim „znakovima navještenja“: anđeli iznad Lukina balkona, ognjena kočija na nebu, kip Bogorodice koji plače...

Kronika suca Andrije DE INFERNIS ANNOTATIONES (Zapisi o paklu) velikim se dijelom odnosi upravo na rekonstrukciju događaja koji su prethodili potresu. Stoga Andrijin zapis progovara iz postapokaliptičke pozicije, donoseći, oslanjanjem na sve najave katastrofalnoga događaja, tumačenje potresa apokaliptičkim diskursom.

Ipak, veliki se potres u romanu Oslobađanje đavola ne može uklopiti u potpunosti pod ideju traume kao razlomnoga događaja. Naime, u društvenome kontekstu ,trauma ima ulogu razlomnoga događaja, kako tvrde suvremeni istraživači traume, samo ako se društvena i povijesna stvarnost poima kao dovršena i cjelovita “(Mijatović 2009: 143).

U svijetu Šehovićeva romana, zasnovanome na slici povijesne vrtnje, a ne ideji cjelovitosti i dovršenosti, percepcija dubrovačkoga potresa kao najavljivane apokalipse udaljava se od fenomena razlomnoga, a približava kategoriji uobičajenog, očekivanog. Taj potres tek je

${ }^{183}$ Po ovoj karakternoj sastavnici lik Luke analogan je liku fra Vincenca iz Gorkoga okusa duše. 
jedan od brojnih povijesnih ,potresa“ u nizu, a ne graničnik nakon kojeg se otvara mogućnost nove etape, novoga doba.

Stoga ostaje tek (retoričko) pitanje: Može li se u svijetu (romana) u kojem traumatsko postaje očekivano pravilo, a ne iznenađujuća iznimka, uopće više govoriti o traumatskome (u kliničkome kontekstu)?

\section{2. (Ne)iskazivost traume i svjedočenje}

Da bi na slikovit način prezentirao prirodu traumatskoga iskustva, Freud se okreće epu talijanskoga književnika Torquata Tassa Oslobođeni Jeruzalem. Cathy Caruth tvrdi da Freud u ovom slučaju pribjegava književnome predlošku jer je „literatura, poput psihoanalize, zainteresirana za kompleksan odnos između znanja i neznanja“ (1996: 3).

Riječ je o prizoru iz Oslobođenoga Jeruzalema u kojemu vitez Tancredo nehotice i ne znajući što zapravo čini, ubija svoju voljenu Clorindu. Poslije toga čina zabije mač u drvo, pri čemu poteče krv iz rane na drvetu te se začuje Clorindin glas s optužbom Tancredu da joj je još jednom nanio zlo. Tancredo je tako tek ponavljajućom gestom povezan s izvornim događajem, onim kojega nije svjestan.

Iz slike Tancredova mača zarivenoga u drvo iz kojega izlazi Clorindin glas, Caruth (1996: 8) zaključuje kako je vlastita trauma uvijek vezana za traumu drugoga. Ova autorica (1 - 8), analizirajući upravo opisani prizor iz Tassova epa, naglasak kontinuirano stavlja upravo na „glas koji plače“, „glas koji je propušten kroz ranu“, „ranu koja vrišti“, upućujući time na ulogu adresata i potrebu svjedoka traume da govori i da ga se čuje. Upravo je ova postavka C. Caruth jedna od značajnijih smjernica u problematizaciji (ne)iskazivosti traumatskoga iskustva: Koji je odnos traume i jezika, odnosno može li se (i ako da - kako) trauma jezično artikulirati?

U promišljanju o reakciji na traumu, Ruth Leys konstruira mimetičku, odnosno antimimetičku teoriju (v. Biti 2005: 22): mimetička teorija podrazumijeva traumatizirani subjekt koji ne može prizvati događaj, događaj izmiče pamćenju te je osuđen na hipnotičku imitaciju; po antimimetičkoj teoriji traumatizirani subjekt uspijeva se distancirati od traumatskoga događaja, zbog čega traumatsko postaje izvanjski događaj. 
Zadatak terapeuta, prema Freudu, leži upravo u nastojanju da traumatizirani subjekt odmakne od toga da potisnuto ponavlja kao sadašnji doživljaj te ga se, umjesto toga, sjeća kao prošlosti (1986: 146, isticanja Freudova), odnosno da pacijenta prevede ,iz mimetičkog registra u antimimetički registar“"(Mijatović 2009: 153).

Iako ističe važnost „glasa“ traumatskoga, Caruth ne vjeruje u mogućnost jezične artikulacije traumatskoga, smatrajući da svijest čovjeka ne može proraditi (working through) traumatski događaj, već ga samo odjelotvoriti (acting out), dakle traumatičan događaj dolazi do svijesti jedino u svom ponavljajućem obliku (v. Biti 2005: 13; Caruth 1996: 3).

S druge strane, analizirajući odnos traumatskoga i povijesnoga putem psihoanalitičkoga aparata, Dominick LaCapra ističe važnost prorade traumatskoga, premda upućuje da proces prorade ne isključuje odjelotvorenje (v. 2001: 22).

Pretakanje traumatskoga u narativ može se sagledati kao dio terapijskoga procesa (v. Laub 1992: 69), i to upravo u kontekstu spomenutoga antimimetičkoga modela, odnosno prorade traumatskoga.

Poput suvremenih teoretičara traume, Šehović u svojim povijesnim romanima razlikuje „kliničke i terapeutske aspekte traume od imperativa njezine reprezentacije i interpretacije“ (Mijatović 2009: 143), i to na tragu kulturalnog teoretičara Kirbyja Farrella koji, gledajući na traumu (i) kao na kulturalni trop, tj. figuru, ističe da „ozljeda zahtijeva interpretaciju“" (isto: 144).

Jezična (re)prezentacija traumatskoga u Šehovićevim romanima ne oslanja se na neke specifične retoričke oblike, među kojima je najpoznatija primjena Barthesova „srednjega glagolskog stanja““184. Naime, upravo ovakvo stanje, koje nije ni aktivno ni pasivno ${ }^{185}$, uočava Hayden White (2004.), prikladno je za prenošenje događaja „koji su posebno opterećeni afektivnim odnosom i vrijednosnim mjerilima“ (Badurina 2010: 192). Međutim, LaCapra se, s druge strane, pita i hoće li taj „,srednji glas“ ukinuti binaran odnos žrtva - počinitelj, a time i pitanje odgovornosti (v. 2001: 26).

Analogno LaCaprinoj tezi da je pisanje povijesti zapravo pisanje traume, i Šehovićevi romani demonstriraju ideju da je pisanje (suvremenog) povijesnog romana također pisanje traume, s tim da se pisanje traume razlikuje od pisanja o traumi (istaknula D. M. L.): pisanje

\footnotetext{
${ }^{184}$ Hayden White (v. 2004: 630 - 635) u svome se eseju o historijskoj pripovjednosti i problemu istine u historijskome prikazivanju poziva na esej Rolanda Bartha „Pisati: Intranzitivan glagol?““.

${ }^{185}$ Neki od postupaka kojima se može simulirati ovakvo srednje glagolsko stanje (istodobno aktivno i pasivno, a s druge strane, ni aktivno ni pasivno) jesu: slobodni neupravni govor koji je dijalogiziran iznutra i neodlučan u pogledu glasa, prekidi u pripovijedanju s promjenama gramatičkog lica pripovjedača, elipse, paralepse, lomovi... (v. Badurina 2010: 193).
} 
o traumi odnosi se na pokušaj što objektivnije rekonstrukcije prošlosti, a pisanje traume uključuje kazivanje onog posttraumatskoga, dakle poslije-efekata, pri čemu se procesima odjelotvorenja i prorade daje „glas“ prošlosti (LaCapra 2001: 186).

U (ovoj našoj) kulturi, označenoj etiketom posttraumatskoga (v. Felman 1992b), svjedočenje zauzima značajnu poziciju, zbog čega se 20. stoljeće (ali i njegov nastavak) mogu promatrati kao doba svjedočenja. Promatrajući relaciju svjedočenje - događaj, Shoshana Felman zaključuje kako je „svjedočenje postalo krucijalni modus naše poveznice s događajima našeg vremena - naše veze s traumama suvremene povijesti““ (1992b: 5). Kako su to ranija poglavlja ovoga rada pokazala, upravo je pozicija svjedoka, odnosno tekstovi svjedočenja konstanta Šehovićevih romana u kontekstu (re)prezentacije traumatskoga.

U odnosu prema nekim teoretičarima traume, koji naglašavaju potrebu svjedoka traume da ga se čuje, ali i nemogućnost jezične artikulacije traume u smislu njezine narativizacije (Caruth 1996), zbog čega se svjedočenje o traumi svodi jedino na svjedočenje o nemogućnosti svjedočenja traume (Felman 2007) ${ }^{186}$, Šehovićevi povijesni romani u okviru karakterizacije protagonista podcrtavaju upravo pokušaj narativizacije traumatskoga - pretvaranje traume u priču.

Čak i kad se ovom pretvorbom ne uspije na individulanoj razini postići terapijski efekt, primjerice nije izbjegnut suicidalan čin protagonista (Vicko u Gorkom okusu duše), motto svih Šehovićevih protagonista-svjedoka predstavlja „,imperativ pričanja“ (Laub1995: 62), i pod cijenu udruženosti s „nemogućnošću pričanja“ (isto: 64). Jer pričati se mora, budući da „nepričanje priče služi perpetuiranju tiranije““ (isto).

Svjedočenje u ovome smislu predstavlja poseban oblik priče, onaj koji nužno zahtijeva adresata, dakle svoga slušatelja. Primjeri iz Šehovićevih romana to su zorno pokazali. ${ }^{187}$ Svjedočenje je tako nužno dijalogičan čin, pri čemu adresat postaje svjedokom stanovite priče o traumatskome, bivajući tako i sam uključen u nju. Time se dužnost svjedočenja lančano nastavlja. Individualna trauma postaje kolektivna trauma, ali i kolektivna odgovornost. Iako se spomenutim pokušajem pretvaranja traumatskoga iskustva u priču putem svjedočenja uočava (i) antimimetički modus traumatskoga na razini likova, prostornovremenski aspekt Šehovićevih povijesnih romana demonstrira neizbježnost mimetičkog u pristupu traumatskome, upućujući tako na nužnu simbiozu ova dva modusa.

\footnotetext{
186 „Nemogućnost pričanja nije izvanjska (toj) priči: ona je u središtu priče.“ (Felman 2007: 191)

${ }^{187}$ Usp. prethodna poglavlja ovoga rada koja se tiču svjedoka i testimonijalnih dokumenata.
} 


\subsection{Društvena trauma - načelo ponavljanja}

Kao uporište pri promatranju traume u društvenome kontekstu poslužit će postavke traumatologinje i kulturne povjesničarke Anngwyn St. Just, koja traumu promatra na relaciji prostor - vrijeme - fraktalnost ${ }^{188}$.

Pomicanjem gledišta s individualne na globalnu razinu, odnosno pri istodobnome obuhvaćanju obje razine, uključujući i sve oblike stanovitih međurazina, dolazi se do zaključka da trauma pojedinca nikad nije samo pojedinačna trauma. Ona je trauma svih onih koji su u vezi s tim pojedincem, a u općenitom smislu i kolektivna trauma, kako je to figurativno shematizirao Bert Hellinger u radu sa sistemskim konstelacijama:

„Baveći se klijentom, počeo je uviđati nešto poput delikatnog fragmenta žile na listu, zatim cijeli list, peteljku, granu, stablo, a onda i cijelu šumu...i šire.“ (St. Just 2012: 48)

Dakle, na neki način trauma pojedinca preslikava se na znatno šire društvene strukture, zbog čega se trauma može promatrati i u povijesnome kontekstu - kao povijesna trauma. Ovakvo preslikavanje pojedinačnoga na opće, pronalaženje nekog općeg zakona u pojedinačnome, međusobno ogledanje mikrokozmosa i makrokozmosa, dovodi Anngwyn St. Just do postavke o traumi kao fraktalnome fenomenu.

„Otac fraktalne geometrije“ Benoit Mandelbrot (1924. - 2010.) skovao je termin fraktal iz latinskoga korijena fractus (fragmentiranost, razlomljenost, diskontinuitet), upućujući time da se priroda fraktalnoga temelji na ideji kako je svaki dio kao cjelina - samo manji (St. Just 2012: 41 - 42).

St. Just naglašava da je fraktalnost sasvim prirodna i sveprisutna pojava, kako u strukturi samoga čovjeka (npr. fraktalnost ljudskog živčanog sustava), tako i u prostoru oko čovjeka (npr. uzorak lista, riječno korito...).

I prirodu vremena vidi kao fraktalnu, što zorno prikazuje kalendar Maya, koji funkcionira kao nelinearni sustav međusobno povezanih almanaha/godišnjaka koji reflektiraju fraktalnost svemira (isto: 20). Ovakav je ciklički, pa i spiralni, pristup vremenu suprotan linearnosti kršćanskoga kalendara, koji dovodi do svojevrsne promjene u percepciji vremena te pokušaju kontroliranja ljudi (v. isto: 13 - 33).

Stoga je doživljaju traume, čiji je temelj repetitivnost, puno bliži fraktalni nego linearni ustroj vremena.

\footnotetext{
${ }^{188}$ Riječ je o knjizi Trauma: Time, space and fractals (A systemic perspective on individual, social and global trauma).
} 
Stari aksiom „kako gore - tako dolje, kako dolje - tako gore“ (v. isto: 3, 45), uzet kao neka vrsta formule i u slučaju fraktalnosti traume, slikovito je prikazan posebice u Šehovićevoj sagi o Ilijasbegovićima.

Gubitničke sudbine svakoga od protagonista svih pet romana Ilijasbegovića, osim što se nadovezuju jedna na drugu generacijski ${ }^{189}$, zrcale se u gubitničkoj sudbini same obitelji Ilijasbegovića, ali i u sudbini bošnjačkoga entiteta tijekom povijesti, ostvarujući tako fraktalni obrazac pojedinac - obitelj - nacija.

U tome smislu, jedno će od narednih potpoglavlja ovoga rada ukazati na korespondentan odnos između karakterizacije protagonista-svjedoka u Ilijasbegovićima ${ }^{190}$ i identitetnih predodžbi o Bošnjacima, uključujući korespondentnost kismeta ${ }^{191}$.

St. Just upozorava kako trauma u sebi sadrži samoponavljajući uzorak, a taj se uzorak ponavlja kad god je nešto poricano, prešućeno ili zataškavano (2012: 73, 277...).

Svi romaneskni predstavnici obitelji Ilijasbegović, kao i sami Bošnjaci u ovoj sagi, postaju u povijesnome kontekstu model žrtvenoga jarca upravo zbog prešućivanja istine o određenim povijesnim događajima.

Ilijas-begu (Ilijas-beg, kapetan trebinjski) trebinjska je vlast, ista ona koja se u početku divila njegovim pobjedama nad mletačkim uskocima i diplomatskim odnosima s Dubrovačkom Republikom, smjestila optužbu da se potajno dogovarao s Dubrovčanima, kao i onu za zločinačke upade u Konavle.

Hasan-beg (Inšallah), isprva u svome Trebinju dočekan kao heroj u borbi protiv vojnika Eugena Savojskoga, biva lažno optužen za suradnju s neprijateljima te etiketiran kao izdajnik „svojih“.

Protagonist Begovine Ilijas-beg, zapovjednik jednoga bošnjačkog odreda u sklopu austrougarske vojske koja se talijanskim snagama suprotstavljala na bojištima Soče i Piave (Prvi svjetski rat), skupa je sa svojim potporučnikom židovskoga podrijetla nevin završio pred talijanskim sudom jer netko je ipak morao odgovarati za pokolj što ga je nekolicina vojnika počinilo nad civilima u jednom talijanskom selu.

Njegov unuk i imenjak, nositelj glavne fabularne linije u Dubrovačkome intermezzu i u Od Mostara do Den Haaga, doživljava scenarij svojih predaka. Iako je u vrijeme masakra nad bošnjačkim civilima u jednom bosanskom selu (vrijeme rata u BiH) Ilijas bio u nekoj vrsti

\footnotetext{
${ }^{189}$ Ilijas-beg, trebinjski kapetan iz 17. st. - Hasan-beg iz 18. st. - Ilijas-beg iz vremena Prvoga svjetskog rata Enver-beg iz vremena Drugoga svjetskog rata - Ilijas te mlađi rođak Enko iz nedavnog rata u BiH

${ }^{190}$ Vidi potpoglavlje ovoga rada „Svojstva likova svjedoka i njihova naratološka izgradnja“.

${ }^{191}$ kismet - sudbina, usud
} 
kućnoga pritvora, te je istražio i oštro osudio taj zločin, ovaj je general-bojnik HVO-a od strane bosanskih medija prikazan kao lažni domoljub i izdajnik „svojih““.

Romaneskna saga o Ilijasbegovićima završava prizorom u kojem Ilijasov mlađi rođak Enko provodi u haaškom zatvoru svoje dane kao osuđenik za ratne zločine po vojnoj odgovornosti:

„Ne robijam zato što su me njihovi optužili, još uvijek obuzeti otrovom mržnje i želje za osvetom, već zato što su neki naši, uništili dokaze o mojoj nevinosti. (...) Znao sam da me žrtvuju...(I: 1002)

Iz prethodnih je fabularnih specifičnosti vidljivo kako su protagonisti Ilijasbegovića osuđeni, kažnjeni i proganjani upravo zato što u okvirima službenoga povijesnog govora, realiziranoga kao govor struktura vlasti, istina nije mogla izići na vidjelo.

Njihovo svjedočenje, kao i svjedočenje njihovih bližnjih u vidu sekundarnih svjedoka, pokušaj su revizije i korekcije glasa službene povijesti ${ }^{192}$.

Analogna situacija vidljiva je i u ostalim Šehovićevim povijesnim romanima, s tim da posebno jasno dolazi do izražaja u Prokletoj ergeli.

Fabula ovoga romana kompozicijski je ostvarena putem dvodijelne strukture (pri čemu je drugi dio znatno dulji): nositelj prvoga dijela je lik fra Ilije, a drugoga dijela lik fra Andrije. Riječ je o likovima bosanskih franjevaca kojima je dodijeljena uloga posrednika među zaraćenim stranama budući da sudjeluju u pregovorima o uvjetima okončanja mletačkoturskih, a time i kršćansko-muslimanskih sukoba na Klisu (1596. godine i 1648. godine). Ilijina i Andrijina pregovaračka misija imaju isti cilj - spriječiti iživljavanje neprijatelja nad poraženim vojnicima suprotne strane. U prvome slučaju riječ je o turskom ultimatumu s načelom ,parcendum est victis“ (treba štedjeti pobijeđene), a u drugome o istovjetnome mletačkome ultimatumu.

Iako su u početku fra Ilija i fra Andrija doživjeli ugled zbog svojih pregovaračkih vještina, tijekom vremena doživljavaju istu sudbinu (a koja se poklapa sa sudbinama svih ostalih protagonista Šehovićevih romana): završavaju u zatvorima (Ilija u splitskom, Andrija u bosanskom) pod optužbama da su surađivali s neprijateljskom stranom te su slijedom toga izdajice „svojih“(Ilija optužen kao turski špijun, Andriji pripisana odgovornost za ubojstvo nekoliko stotina turskih branitelja prilikom druge opsade Klisa).

\footnotetext{
${ }^{192}$ Iz toga razloga svoju ,istinu“ putem testimonijalnoga modusa Ilijas-beg (17. st.) iznosi fra Matiji, Hasan-beg prijatelju Enesu, Ilijas-beg fra Ivanu Lovrenoviću, Enko fra Petru...
} 
Za razliku od prve opsade Klisa (1596.), kad je pravilo o milosti prema pobijeđenima bilo poštovano, u drugom pokušaju opsade Klisa (1648.) došlo je do iskaljivanja gnjeva nad muslimanskim braniteljima od strane kršćanskih predstavnika u prostoru tzv. ,,proklete ergele“.

Opet na snagu stupa načelo ,zataškavanog, poricanog, prešućenog“ (Anngwyn St. Just) od strane službene verzije događaja:

„Nažalost, u povijesnim knjigama toga vremena, širom Europe moglo se dosta toga pročitati o herojskom pokušaju kršćana da oslobode klišku trđavu. Niti spomena nije bilo o uspješno provedenom ugovoru, sačinjenom po ljudskoj i Božjoj mjeri. Pisalo se, ili kako bi pokojni fra Ilija volio reći - guslalo, isključivo o herojstvu i hrabrosti kršćanskih bojovnika, europskih vitezova ili domaćih uskoka i gusara te velikoj mudrosti kršćanske vlasti i crkvenih velikodostojnika. Ni riječi o svirepim ubojstvima i pljački nedužna naroda, ili prisilnom pokrštavanju nekršćana.“(PE: 68)

U svome radu s traumom kao fraktalnim obrascem Anngwyn St. Just uočava ključnu ulogu povijesti nekog mjesta te godišnjice razdvajanja ili kidanja veza, dakle povezuje traumu sa specifičnim spacijalnim i temporalnim oznakama.

Po pitanju godišnjica, uočava se identičan temporalni okvir nekih protagonista svjedoka u Ilijasbegovićima: Ilijas će samoubojstvo počiniti u šezdeset i nekoj godini života (Od Mostara do Den Haaga), kao i djed mu Ilijas-beg (Begovina). Zanimljivo je da se ovaj suicidalni niz može vratiti do prvoga romana dubrovačke trilogije - Gorak okus duše, kad su Vicka „u njegovoj šezdeset i petoj godini života, sinovi (su ga) pronašli obješena u staji“ (GOD: 145).

Pri analizi konstelacije traume i povijesti određenih mjesta Anngwyn St. Just poziva se na ideju biologa Ruperta Sheldrakea o poljima pamćenja/sjećanja (fields of memory) prostorima koji igraju značajnu ulogu u traumatskome ponavljanju (2012: 54 - 76).

Riječ je o mjestima na kojima se opetovano tijekom povijesti odigravaju traumatični događaji upravo po prethodno spomenutome načelu da se trauma ponavlja dok god je nešto ostalo (povijesno) neriješeno, zbog čega dolazi do fiksacije $\mathrm{e}^{193}$.

\footnotetext{
${ }^{193}$ U tome kontekstu Anngwyn St. Just navodi povijesni primjer masakra u Katinskoj šumi. U travnju 1940. u Katinskoj šumi Rusi su masakrirali članove poljske elite, a zločin je pripisan nacistima. U travnju 2010. srušio se avion u Katinskoj šumi - u avionu su bili poljski predsjednik i njegova delegacija, koji su putovali u Rusiju na 70-u obljetnicu masakra nad poljskim vodstvom u Katinskoj šumi. (2012: 54 - 57)
} 
Reprezentativan primjer takvoga prostora predstavlja upravo „prokleta ergela“ $u$ istoimenome Šehovićevu romanu. „Prokletstvo“ ovoga mjesta povijesno je zadano:

„Prije pedesetak godina (...) konji u ergeli naglo su oboljeli i za kratko vrijeme većina ih je uginula. Sljedećih godina pokušalo se obnoviti ergelu, ali opet je došlo do pomora konja, ovaj put nijedno grlo nije uspjelo preživjeti (...).

Prije nepunih petnaest godina jedan je od potomaka vlasnika sandžak-bega (...) obnovio ergelu. (...) Nekoliko godina poslije dogodilo se isto prokletstvo. (...) Prokleta ergela, kao što se događa svemu što je prokleto, postala je strašilo i prepuštena je bez milosti zubu vremena.“ (PE: 77)

Godine 1596. tvrđava Klis, čiji je dio „prokleta ergela“, postaje poprište krvavoga sukoba mletačke i turske vojske, a isti se scenarij muslimansko-kršćanske netrpeljivosti ponovio otprilike pola stoljeća nakon (1648.) s još tragičnijim posljedicama. Naime, prilikom druge opsade Klisa, ,prokleta ergela“ postaje mjesto iskaljivanja kršćanskoga gnjeva ne samo nad zarobljenim muslimanskim vojnicima, već i nad muslimanskim civilima - postaje mjesto genocidnih intencija. Prokletstvo započeto motivom konja nastavlja se, ali sad s ljudima kao žrtvama tog kobnog mjesta.

Kako je to LaCapra figurativno izrekao, trauma je poput duha koji se stalno vraća jer je došlo do smetnji u simboličkome poretku (2001: 215). I koliko god to bilo na prvi pogled paradoksalno, traumatsko se vraća s pozitivnim namjerama - da bi se sustav, u nastojanju da dođe do razrješenja, vratio u ravnotežu (v. St. Just 2012: 228).

Fra Andriju ni u tamnici nije napustila nada „da će se osloboditi i imati priliku napisati knjigu o Prokletoj ergeli, velikom i sramnom zločinu, kojega je Europa lako prešutjela“ (PE: 149), dakle opet stupa na snagu potreba da se razotkrije ono što je prešućeno, i to od strane samoga svjedoka događaja. Svjedočenje se na ovaj način, iz pozicije svoga singulariteta, uključuje u proces iznalaženja istine kao u proces koji je neophodan u pristupu traumatskome.

Pripovjedačev komentar kako su se „događali takvi zločini u Bosni i još se događaju“ (PE: 173) sugerira tek nastavak traumatskog ciklusa, pri čemu se ,prokleta ergela“ može promatrati kao sinegdoha svih bosanskih prostora, ali i ne samo bosanskih, na kojima je izvršen genocid nad onima koji predstavljaju drugost.

Ipak, ovoj slici povijesno traumatskoga, a time i ,prokletoga“ prostora, Šehović na kraju Proklete ergele suprotstavlja sliku edenski opisanoga bosanskog prostora na kojem je 


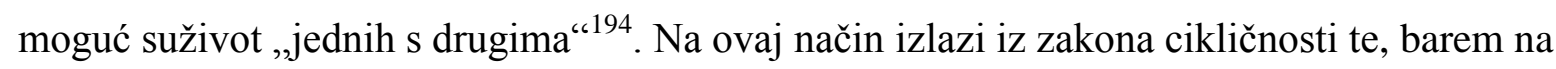
segmentarnoj razini, kreira sliku budućnosti koja može biti različita od prošlosti, nudeći tako u svom posljednjem povijesnom romanu i koncept nade pri razrješavanju traumatskoga.

${ }^{194}$ O ovom odnosu više u narednome poglavlju. 


\section{TESTIMONIJALNO KAO PROSTOR KREIRANJA PREDODŽBI}

\subsection{Kolektivno pamćenje/sjećanje i identitetne predodžbe}

Kako to sam naslov sažima, u ovome će se potpoglavlju uputiti na relaciju pojmova pamćenje/sjećanje - identitet - predodžba, a u svrhu primjene stanovitih teorijskih koncepata na problematiku svjedočenja u Šehovićevim povijesnim romanima.

Pamćenje i sjećanje pojmovi su široke interdisciplinarne primjene, a njihove značenjske sastavnice ostvaruju se u svojoj gotovo beskonačnoj rastegnutosti.

Govoreći o pamćenju u književnoteorijskome okružju, grčku boginju pamćenja Mnemozinu može se sagledati prvenstveno putem njezina dva kontrastna, ali međuuključiva lica autobiografskoga i kulturnoopovijesnoga; u svakom slučaju, pamćenje osigurava neku vrstu konzistentnosti i kontinuiteta, kako na individualnoj razini - na razini pojedinačne ličnosti, ali i na kulturnopovijesnoj razini (v. Benčić 2006: 5 - 9). ${ }^{195}$

Distinktivna nota između pamćenja i sjećanja ${ }^{196}$, u smislu odnosa prema prošlosti, kod nekih je autora naglašenija, pa je tako pamćenje vezano uz usvajanje i zadržavanje informacija, a sjećanje uz njihovo „oživljavanje“ i aktualizaciju (usp. Kuljić 2006: 8; Brkljačić - Prlenda 2006: 17). U tome bi smislu pamćenje predstavljalo određeno „skladište“, a sjećanje ,intervenciju“ u njegov sadržaj, na što još upućuju i Platonove kategorije mneme i anamnesis:

„Ako je pamćenje (mneme) povezano s umijećem pohranjivanja onoga što se ne smije izgubiti u zaboravu, sjećanje (anamnesis) je ona kategorija koja će pripomoći da se ono što je potonulo u zaborav opet vrati.“(v. Lachmann 2002: 439)

Ipak, odnos među ovim kategorijama mnogo je fluidniji nego se to čini, zbog čega neki autori (npr. Jan Assmann) u svojim radovima dosta slobodno koriste ove pojmove, na razini

\footnotetext{
${ }^{195}$ U svojoj knjizi Lica Mnemozine Živa Benčić tako donosi niz ogleda o pamćenju u kojima je dominantno jedno od spomenutih ,lica Mnemozine“, ili je pak na snazi njihova neminovna interakcija.

${ }^{196} \mathrm{U}$ engleskome jeziku pamćenje i sjećanje obuhvaćeni su zajedničkim pojmom memory (Englesko-hrvatski rječnik, Školska knjiga, Zagreb, 1999: 684), a i hrvatski jezik tretira ih kao sinonime upućujući sjećanje na pamćenje, i obratno, te u odnosu prema memoriji (v. npr. Šarić - Wittschen, Rječnik sinonima hrvatskoga jezika, Naklada Jesenski i Turk, Zagreb, 2010: 325; Bratoljub Klaić, Rječnik stranih riječi, Školska knjiga, Zagreb, 2007: 867).
} 
istoznačnica, ukazujući (i) time na njihovu međusobnu uvjetovanost i nemogućnost oštroga odjeljivanja. ${ }^{197}$

I pamćenje i sjećanje nezaobilazne su kategorije prilikom interpretativnih zahvata povijesnih romana budući da je njihov svijet izgrađen na odnosu prema prošlosti, a time i na odnosu prema zapamćenom / prema onome čega se sjeća, čime se ostvaruje interaktivni suodnos prošlosti, sadašnjosti, ali i budućnosti.

Prilikom problematizacije iskazivanja prošlosti kao pamćenja francuski filozof Paul Ricoeur poseže za Aristotelovim tekstom O pamćenju i prisjećanju te zaziva metaforu otiska ili traga, u kojoj se združuju prisutnost, odsutnost i anterioritet: riječ je o prisutnosti koja upućuje na odsutnost prošlosti (2006: 800 ). Ovakva se konstelacija prisutnoga i odsutnoga vidi i kod Renate Lachmann (2002: 192) kad sjećanje prezentira kao „predstavljanje odsutnoga slikom (phantasma, simulacrum)“.

Koliko god je za odnos prema prošlosti važno pamćenje i sjećanje, toliko je nezaobilazna i njihova druga strana - zaborav.

U svojoj knjizi O korisnosti i štetnosti historije za život (2004.) Friedrich Nietzsche zagovara ravnotežu sjećanja i zaborava, govori o određenoj dozi produktivnoga zaborava kao neke vrste ,zdravoga“ zaborava. Kao što je istaknuo kritički odnos prema povijesti (u suprotnosti s monumentalnim i antikvarnim), tako ističe i moć kritičkog zaborava. Jedino tako prošlost neće biti nekakav uteg koji koči pojedinca/društvo; umjesto toga prošlost će se otvoriti budućnosti.

Poput Nietzschea, i Ricoeur govori o funkcionalnoj ravnoteži sjećanja i zaborava, da ne bi došlo ni do ,previše sjećanja“ ni do ,previše zaborava“, s tim da ovaj filozof ipak konstantno ustraje na dužnosti sjećanja i dužnosti nezaboravljanja te potrebi da se govori o prošlosti koliko god ona bolna bila (2006: 807).

Iako se u recentno doba granice među pamćenjem i povijesti sve više zamagljuju i stapaju (usp. Kuljić 2006: 123 - 128), neki su teoretičari dosljedno naglašavali antagonizam među ovim dvama fenomenima. Tako francuski povjesničar Pierre Nora, između ostaloga, ističe da je povijest univerzalna budući da pripada svakome i nikome, dok je pamćenje višestruko i razdijeljeno, kolektivno, pluralno i individualizirano (Brkljačić - Prlenda 2006: 25). Iz toga se razloga pamćenje može promatrati u suodnosu s individualnim i/ili kolektivnim identitetima, za razliku od povijesti.

\footnotetext{
${ }^{197}$ Primjerice, u svojoj znamenitoj knjizi Kulturno pamćenje Assmann ne navodi konkretnu razliku među ovim terminima, a kao forme kolektivnoga sjećanja vidi komunikativno pamćenje i kulturno pamćenje (2005: 59 101), čime također zauzima poziciju blisku onoj koja zagovara istovjetnost ovih pojmova.
} 
Cilj ovoga dijela rada nije bavljenje vlastitim/ličnim identitetima, u smislu „svijesti pojedinca o vlastitom kontinuitetu u vremenu i o određenoj koherentnosti njegove ličnosti“ (Erik Erikson), već je naglasak na kolektivnom identitetu - poistovjećivanju pojedinaca među sobom na temelju koncepta zajedničkoga podrijetla ili propisane prošlosti (Kuljić 2006: 155).

U kontekstu odnosa prema prošlosti pamćenje nije samo „matrica“, ali i „reapropriacija povijesne prošlosti“ u sklopu povijesti kao znanosti (historiografija) (Ricoeur 2006), već i u okvirima neznanstvene javne uporabe prošlosti - one koja se može objediniti pod krovnom sintagom kultura pamćenja / kultura sjećanja (v. Kuljić 2006: 10), a u čijem se fokusu nalaze upravo kolektivni identiteti.

Potonji je pristup prošlosti, pamćenju i identitetu uveden i populariziran radovima hajdelberškoga egiptologa Jana Assmanna i njegove supruge anglistkinje i kulturologinje Aleide Assmann te ranije spomenutoga povjesničara Pierrea Nore.

Njihova se istraživanja oslanjaju na „pionira“ koncepta kolektivnoga pamćenja Mauricea Halbwachsa, koji je pamćenje vezao isključivo uz socijalnu komponentu, vjerujući da pojedinac koji bi bio izdvojen iz socijalnoga miljea uopće ne bi imao pamćenje.

Uz ovakav socijalni pristup pamćenju, spomenuti predstavnici kulture pamćenja i sjećanja o prošlosti govore posredstvom postmodernističkoga favoriziranja kategorije konstrukta (prošlost kao konstrukt ovisan o sadašnjici), stoga bi se njihove radove moglo smjestiti u socijalno-konstruktivističke teorije o pamćenju (v. Assmann 2005: 52 - 55; Kuljić 2006: 83 141).

Dok se Halbwachs zadržao na povezivanju pamćenja i grupe, dakle na grupnim identitetima, njegov nasljednik Jan Assmann u svojoj knjizi Kulturno pamćenje (2005.) uvodi kategoriju kulture u problematiku kolektivnoga pamćenja te kao forme kolektivnoga sjećanja vidi komunikativno pamćenje i kulturno pamćenje.

Iz tablice (Assmann 2005: 65) koja donosi značajke komunikativnoga i kulturnoga pamćenja vidljive su njihove razlike. Komunikativno pamćenje moglo bi se nazvati i generacijskim jer su njegovi nositelji članovi najviše 3 - 4 generacije, zbog čega je ono vezano za ne tako daleku prošlost. S obzirom da je medij komunikativnoga pamćenja živa riječ svjedoka pojedinih događaja, njegov je vijek trajanja ograničen.

Za razliku od „svakodnevnosti““ komunikativnoga pamćenja, kulturno pamćenje vezuje se za posebne trenutke, svetkovine. Ono je „usidreno“ mnogo dublje u prošlosti, posjeduje specijalizirane prenositelje (npr. bardovi, učitelji, pisari, svećenici), a sačuvano je u medijima čvrste objektivacije, čime mu je osigurana trajnost. 
Aleida Assmann mišljenja je kako uopćena opozicija individualno - kolektivno pamćenje uopće nije opravdana ${ }^{198}$, zbog čega je, uvodeći kriterije prostornog i vremenskog radijusa, veličine grupe te postojanosti, dodatno raščlanjuje na pamćenje pojedinca, pamćenje socijalne grupe (odgovara karakteristikama komunikativnoga pamćenja kod Jana Assmanna), pamćenje nacije kao političkog kolektiva te pamćenje kulture (2011: 19 - 71).

Sljedeće potpoglavlje, usmjereno na identitetni model Bosanca/Bošnjaka, primjer je prezentacije nacionalnoga pamćenja (kao tipa kolektivnoga pamćenja) u području književnosti. Tom će prilikom, kao i u posljednjem potpoglavlju koje se bavi slikom Bosne, od teorijskoga značaja biti i koncept predodžbi, odnosno pristup imagologije kao ,posebne istraživačke grane komparativne književnosti (koja se) bavi proučavanjem književnih predodžbi o stranim zemljama i narodima (heteropredodžbe) te o vlastitoj zemlji i narodu (autopredodžbe)““ (Dukić 2009: 5).

Mada imagološki pristup najčešće uključuje nadnacionalnu i interdisciplinarnu vizuru $^{199}$, književnim predodžbama o domaćem i stranom identitetu te domaćim i stranim prostorima opravdano je prići i isključivo s književnoga stajališta te u okvirima nacionalne povijesti književnosti ako su takve autopredodžbe i heteropredodžbe, kako to ističe aachenski imagolog Hugo Dyserinck, ,,istaknut dio tematskog svijeta nekih fikcionalnih djela, čak i pri intrinzičnome razumijevanju“ (Dukić 2009: 12).

A upravo su predodžbe o bošnjačkom i bosanskom identitetu te o Bosni nezaobilazan element pri interpretaciji Šehovićevih posljednih povijesnih romana - ciklusa Ilijasbegovići: Cronica travuniana (2002.) te Proklete ergele (2009.). Najpotentnije mjesto na kojem se takve predodžbe u Šehovićevim romanima kreiraju jesu zapisi svjedoka.

\footnotetext{
198 „Kritika pojma 'kolektivno pamćenje' koju sam ja sama izrazila ne odnosi se na njegove tobožnje mističke ili metaforičke premise, nego jedino na njegovu neodređenost, zbog čega je ovdje predloženo da on bude zamijenjen pojmovima 'socijalnog' i 'političkog' odnosno 'nacionalnog pamćenja.“ (2011: 69 - 70) I Susan Sontag kritizira termin „kolektivno pamćenje“ budući da ne može zamisliti pamćenje koje bi bilo nezavisno od organske baze, zbog čega je za ovu teoretičarku svako pamćenje individualno. (usp. Assmann 2011: 30 - 31)

${ }^{199}$ Usp. npr. rad Istvana Frieda „Imagološka pitanja“ u zborniku Kulturni stereotipi: Koncepti identiteta u srednjoeuropskim književnostima: „Francuska komparatistička škola naglašava da je jedno od najvažnijih područja djelovanja za komparativnu književnost upravo imagologija, koja se formira odmah nakon zahtjeva za transtekstualnošću, te se slika nacije predstavljena u književnim djelima ne treba analizirati samo s književnoga aspekta i možda ju uopće ne treba analizirati s toga gledišta, nego bi u obzir trebalo uzeti povijesne, nacionalnopsihološke, često čak sociološke i antropološke aspekte.“ (2006: 71)
} 


\subsection{Bošnjak i Bosanac kao identitetni modeli}

U kontekstu propitivanja identitetnih oznaka kategorija Bošnjak i Bosanac u Šehovićevim povijesnim romanima Ilijasbegovići: Cronica travuniana (2002.) te Proklete ergele (2009.) valja naglasiti kako „,identitet nije pitanje ontologije, nego imagologije i ideologije“ (Oraić Tolić 2006: 30). Naime, imagološkim se pristupom ne nastoje utvrditi nacionalni karakteri, kakav je netko, u relaciji prema pretpostavljenoj empirijskoj stvarnosti, već je uvijek riječ o tome kako je neki nacionalni karakter percipiran i reprezentiran (Leerssen 2009: 87).

Predodžbe nacionalnih karaktera izjednačene su s određenim kompletom stereotipa i klišeja (isto: 85 ), zbog čega se umjesto termina autopredodžbe/heteropredodžbe mogu rabiti i izrazi autostereotipi/heterostereotipi (v. Oraić Tolić 2006), pri čemu stereotipu valja prići kao „okamenjenoj identitetskoj slici““(Oraić Tolić 2006: 30).

Književnost kao diskurzivna praksa nije tek prostor pasivne prezentacije određenih nacionalnih stereotipa, ona i aktivno sudjeluje u njihovoj kreaciji i popularizaciji (v. Fried 2006: 79; Culler 2009: 137).

Budući da imagologija nije sociologija, te ne nastoji u sociološkom smislu „razumjeti““ društvo, već je područje njezina interesa tekstno/intertekstno (Leersen 2009: 179), i u ovome radu identitetima se prilazi isključivo na diskurzivnoj razini, u smislu tekstualne (re)prezentacije. Predodžbe o Bosancima/Bošnjacima/Bosni promatrat će se kao „strukturni elementi estetskog konteksta“ (Fischer 2009: 38) povijesnih romana Feđe Šehovića.

Šehović termine Bošnjak i bošnjački koristi u sagi o Ilijasbegovićima, pri čemu im prilazi dvojako: najčešće se ti izrazi odnose na bosanske muslimane (tada koristi sintagmu Bošnjaci-muslimani). U nekim sekvencama ovog petodijelnoga romanesknog ciklusa govori o Bošnjacima svih triju vjera, čime je identitetna kategorija konfesionalno proširena. Upravo na tome tragu u svome posljednjem romanu Prokleta ergela kreira identitetski obrazac Bosanac, upućujući njime na sve one koji su vezani za prostor Bosne, bez obzira na druge vrste „pripadnosti““.

Od prvoga do posljednjeg romana ciklusa o Ilijasbegovićima protežu se testimonijalni zapisi koji služe i kao poligon za propitivanje nacionalnih identitetnih predodžbi.

Pri tome su upečatljivi zapisi likova franjevaca, koji iz pozicije svjedoka sudbine određenih članova obitelji Ilijasbegović, prezentiraju stanovite bošnjačke/bosanske identitetske značajke: 
fra Matija - Ilijas-beg (Ilijas-beg, kapetan trebinjski), fra Ivan Lovrenović - Ilijas-beg (Begovina) i fra Petar - Enko Ilijasbegović (Od Mostara do Den Haaga).

Ena Begović Sokolija (2017.) u svome radu koji se bavi predodžbama o franjevcima u suvremenoj bošnjačkoj književnosti, a u kojem se nakratko dotiče i likova franjevaca u Ilijasbegovićima (spominje fra Matiju i fra Petra), franjevce vidi kao „figure sjećanja“ u smislu „,mjesta pamćenja“ ${ }^{\text {200 }}$ u suvremenoj bosanskohercegovačkoj književnosti, mjesta pomoću kojeg zajednica proizvodi i održava kolektivno pamćenje (64).

Identitetne predodžbe o Bošnjacima u Šehovićevim romanima razvijaju se putem konfesionalne binarne opozicije (kršćanstvo - islam), a što se u pojedinim segmentima romanesknoga ciklusa vezuje i uz opreku Europa - Balkan.

S obzirom da je nemoguće stvarati sliku vlastitoga koja ne bi uključivala sliku tuđega ${ }^{201}$, identitetska problematika uključuje pitanje alteriteta, stoga imagološka čitanja nužno zahvaćaju interaktivnu dinamiku autopredodžbi i heteropredodžbi.

Književne se predodžbe Bošnjaka u Ilijasbegovićima mogu promatrati u okviru stereotipizacije Balkana i balkanskoga u promišljanjima balkanističkoga diskursa Marije Todorove (1999.): redovito je naglašeno otomansko nasljeđe Balkana (31), nasilnost (212) te anticiviliziranost (324), odnosno Balkan je i u ovom slučaju neka „tamna strana Europe“, „,skladište negativnih karakteristika naspram koje je konstruirana savršena slika Zapada“ (323 - 324).

Ukratko, percepcija Bošnjaka (kao prototipa Balkanca) od strane kršćanske / europske pozicije temelji se na konceptu zazornosti Julije Kristeve, u smislu onoga što „remeti red“, „suprotstavlja se mojemu ja“ i ,predstavlja ograde moje kulture“ (1989: 8).

U tome kontekstu reprezentativna je predodžba o Ilijas-begu (posredovana zapisom njegova prijatelja fra Ivana Lovrenovića), protagonistu Begovine, koji kao zapovjednik jednog bošnjačkog odreda u sklopu austro-ugarske vojske na bojištima Soče i Piave (Prvi svjetski rat), skupa sa svojim potporučnikom židovskoga podrijetla nevin završava pred talijanskim

\footnotetext{
${ }^{200}$ Kako to i sama autorica napominje, riječ je o Norinu terminu „mjesto pamćenja“ te Assmannovoj „figuri sjećanja“.

Pierre Nora tvrdi da „mjesta pamćenja“ (npr. muzeji, arhivi, praznici, spomenici, određene knjige) reguliraju prisustvo prošlosti u sadašnjosti kombinacijom materijalnih, funkcionalnih i simboličkih aspekata prošlosti (v. Kuljić 2006: 107).

Dok njegov prethodnik i učitelj Maurice Halbwachs koristi termin „slike sjećanja“, Jan Assmann ističe da pod „figurama sjećanja“ razumijeva kulturno oblikovane, društveno obvezujuće slike sjećanja, a pojam figure preferira u odnosu na pojam slike zbog toga što se on ne odnosi samo na ikoničko, već i na, na primjer, narativno oblikovanje (Assmann 2005: 44).

201 „Identitet se ne može konstituirati bez svoje razlike (...), tuđe je sjena koja u stopu prati vlastito, i obratno, vlastito se zrcali u tuđem.“ (Oraić Tolić 2006: 7)
} 
sudom pod optužbom da je odgovoran za pokolj što ga je nekoliko vojnika počinilo nad nedužnim civilima u jednom talijanskome selu:

„Je li logično što su baš njih dvojicu odlučili žrtvovati jer je nemoguće da bi takve zločine mogle počiniti krštene duše sa svojom tisućgodišnjom kulturom, nego samo turski barbari iz Bosne (...) i Židovi, Kristove ubojice?“ (I: 417)

Zanimljivo je pratiti dinamiku, odnosno izmjenjivost samih heteropredodžbi o Ilijas-begu kao reprezentantu Bošnjaka, a čije fokalizacijsko ishodište predstavlja talijanski tisak.

Prije suđenja u talijanskim je novinama

„pod naslovom 'Zvijer je dolijala', pisalo da je taj Turčin isti što stoljećima kolje i ubija kršćane i koji će to i tako činiti sve dotle dok ga se u Europi ne iskorijeni. Velika slika uz članak prikazuje čudovište s fesom na glavi i nožem u zubima, u jednoj ruci drži bocu s rumom, a u drugoj na sablji probodeno dijete.

Doista čovjek protrne od straha gledajući tu paklenu nakazu, slične je fra Ivan često vidio na ilustracijama požutjelih srednjovjekovnih knjiga.“ (I: 424 - 425)

S druge strane, nakon Ilijas-begova pojavljivanja u sudnici, ruši se spomenuta heteropredodžba o Ilijas-begu kao Turcu furiosu (divljem/bijesnom Turčinu) ${ }^{202}$ i kreira nova:

„Očekivali su nakazu i čudovište, a pojavio se Apolon, kako će domalo pisati u lokalnim novinama.“(I: 427)

Ovakvim antagonizmom na razini heteropredodžbi Šehović na estetskoj razini problematizira status slika o Drugome u skladu s imagološkim postavkama: stereotipi, klišeji i predrasude neminovne su sastavnice bilo kakvih predodžbi o onima koje postavljamo u odnos mi - oni.

\footnotetext{
${ }^{202}$ Na ovome mjestu zanimljivo je uputiti na još jedan primjer iz Ilijasbegovića koji potkrjepljuje (inter)tekstualnu zadanost imagoloških kreacija. U petom romanu ciklusa, Od Mostara do Den Haaga, rođak Rus, koji proučava povijesnu pozadinu bošnjačkoga pitanja, pojašnjava protagonistu romana Ilijasu ukorijenjenost nacionalnih stereotipa u prostorima službene povijesti književnosti:

„Kao za neku utjehu, Rus mu reče da ni tu kod njih nije moglo drukčije. Posudio je od Ena čitanku iz književnosti koju je donio sa sobom iz Grada da bi na ferijama naučio zadane lekcije. Pogledaj kako tu djecu uče, rekao je Rus, i stao listati knjigu, pokazujući mu sliku kako Turci kraj mosta koji se gradi nabijaju čovjeka na kolac, zatim slika orgijanja na Gackom polju gdje Smail-aga Čengić nemilice, iz zabave, kolje i sakati kršćansku raju, onda prelazi na sliku bradatog i mudrog Njegoševa filozofa koji ispred svojega manastira poziva kršćane da istrijebe 'gubu iz torine'.“ (I: 866 - 867)
} 
Konstrukcijom predodžbi u prostoru novinskoga tiska te zamjenom jednih drugima u istome prostoru, podsjeća se na uvijek diskurzivno utemeljenje imagoloških konstrukata.

U poglavlju ovoga rada koji se bavio karakterizacijom protagonista-svjedoka $u$ Šehovićevim povijesnim romanima vidljiva je istaknuta uloga motiva patnje i žrtvenosti (motiv žrtvenoga jarca - pharmakosa). I Bošnjaci se kao kolektivan lik u Ilijasbegovićima prikazuju na analogan način, stoga su zapisi o bošnjačkoj sudbini tijekom povijesti obilježeni idejom „bošnjačke golgote“ (I: 478).

Ovakva se predodžba o povijesnome položaju bošnjačkoga naroda ne konstruira samo posredovanjem spomenutih likova franjevaca kao tvorcima intimnih kronikalnih zapisa o sudbinama pojedinih Ilijasbegovića, već i zapisima esejističkih diskurzivnih značajki ${ }^{203}$. Pri tome treba izdvojiti zapise što ih Hasan-beg (Inšallah) piše kao zarobljenik jednoga od časnika Eugena Savojskoga, knjigu fra Ivana Lovrenovića Muslimani i bosanski franjevci (Begovina), Enver-begovu knjigu 'Ko smo to mi muslimani u BiH (Begovina) te zapise Ilijasova rođaka Rusa (Od Mostara do Den Haaga).

Hasan-begov zapis, koji je trebao predstavljati osvrt na knjigu gospara Antuna o odnosu Europe prema Bosni, postaje snažan esejistički trag o problematici bošnjačkoga pitanja. Početna rečenica Hasan-begova zapisa korespondira naslovu Enver-begove knjige 'Ko smo to mi muslimani u BiH: „'Ko smo to i što smo mi Bošnjaci?““ (I: 293). Upravo sintagma „tko smo“ tiče se pitanja kolektivnoga identiteta Bošnjaka / bosanskih muslimana, a koji se iznalazi odnosom prema upamćenome, tj. odnosom prema prošlosti. Pri konstrukciji takvoga identiteta od izuzetne su važnosti i predodžbe drugih o Bošnjacima tijekom povijesti, u ovom slučaju, kako je to već ranije napomenuto, predodžbe „velike Europe“, kršćanske Europe. Takve predodžbe, budući da su po svojoj ontologiji stereotipi i klišeji, počivaju na određenim identifikacijskim „općim mjestima“, na što upućuju i sljedeći navodi iz romanesknoga ciklusa:

„Zašto susjedi drugih vjera toliko žele da nas unište ili protjeraju s ovih prostora? Muslimani smo drage volje budući da se našim pradjedovima islam učinio bliži i prihvatljiviji, a možda i skloniji čovjeku od stare vjere. Nismo postali Turci, iako su to, možda naši novi gospodari s istoka žarko željeli. Sačuvali smo sve što je naše bosansko: i jezik, i običaje i narav. (...) Dokle ćemo ispaštati izmišljeno otpadništvo?“ (iz Hasan-begova zapisa - I: 312)

\footnotetext{
${ }^{203}$ Vidi i potpoglavlje ovoga rada o esejističkim bilješkama kao vrsti dokumenata u povijesnim romanima Feđe Šehovića.
} 
„Imaš pravo, prijatelju, stoljećima našim bližim i daljim susjedima utuvljuju u glavu da smo otpadnici i izrodi koje valja potamaniti ili vratiti tamo gdje bijasmo prije četiri stoljeća. I ja se poput tebe, s gukom u grlu, pitam od čega smo to otpali i u što se izrodili, zašto nas drže korovom kojega treba istrijebiti kad je tebi to što jesmo, tebi, kažeš, blisko ko svoje.“ (komentar Ilijas-bega na zapise prijatelja fra Ivana Lovrenovića - I: 478)

„Rusov cilj bio je očito da dokaže kako je bošnjački narod (muslimani), od svojega postanka do dana današnjeg i tko zna do kada još, izložen neprestanom nasilju zbog brisanja njegove vjere i imena. Zato nije slučajno što je u raspravi Rus rekao da se, nažalost, u tom smislu ništa nije promijenilo i nakon takozvane socijalističke revolucije koja s riječima vatreno zaklinje u bratstvo i jednakopravnost svih naroda $\mathrm{u}$ zemlji: 'Mrze nas i neće nas, to ti je', reče Rus...“ (komentar mladog Ilijasa na Rusove zapise - I: 800)

Svi testimonijalni zapisi u Ilijasbegovićima, bez obzira na diskurzivne karakteristike (intimne kronike, esejistički zapisi i s1.) i status nositelja zapisa (primarni, sekundarni svjedoci) svojim ulančavanjem i dijaloškim odnosom tijekom stoljeća pokazuju kontinuitet misli o bošnjačkome identitetu kao tipu kolektivnoga identiteta. Svi nositelji zapisa imaju za cilj da im pozicija svjedoka omogući pokušaj stanovite revizije povijesnih predodžbi o Bošnjacima, zajednička im je želja da „nova Europa na pravi način prepozna Bošnjakemuslimane“ (I: 475).

Ovakvu tendenciju ne treba promatrati na razini zamjene strereotipa istinom, jer imagološka vizura ne funkcionira na takvim relacijama. Riječ je o potrebi za uključivanjem i drugačijih predodžbi u javni prostor, odnosno o potrebi za njihovim supostojanjem.

U problematizaciji konstrukcije kolektivnoga identiteta putem mehanizama pamćenja i sjećanja Šehović tek manjim dijelom koristi koncept komunikativnoga pamćenja (Jan Assmann) / socijalnoga pamćenja (Aleida Assmann), koji se zasniva na živoj riječi, odnosno usmenoj komunikaciji među članovima generacija (npr. djed - otac - sin). Dominantnu poziciju prisvaja zapis kao „povlašteni oblik prijenosa sjećanja jednoga društva“ (Connerton 2004: 151). 
Za razliku od komunikativnoga odnosno socijalnoga pamćenja, „kolektivno i kulturalno pamćenje počiva na fundusu iskustava i znanja koji se odvojio od svojih živih nosilaca i prešao na materijalne nosioce podataka“" (Assmann 2011: 36), u slučaju Šehovićevih romana na zapis koji svjedoci ostavljaju za budućnost.

Iako je na prvi pogled komunikativno, generacijsko pamćenje, zbog svoje žive komunikacije i neposrednoga kontakta među članovima nekog generacijskoga niza, percipirano kao izrazito tjelesno u odnosu na kolektivno i kulturalno pamćenje, proučavajući „kako se društva sjećaju“ Paul Connerton i sam čin zapisivanja, dakle prenošenje informacija putem npr. tiska i fotografije, vidi kao društvenu praksu povezanu sa sjećanjem nataloženim u tijelu, tj. pisanje mu je usko povezano s tjelesnim aspektom $(2004: 107-155)^{204}$.

Testimonijalni zapisi u Šehovićevim romanima funkcioniraju, riječima Pierrea Nore, kao „,svjedoci jednog drugog vremena, iluzije vječnoga trajanja“ (Brkljačić - Prlenda 2006: 28). Pierre Nora naglašava kako je suvremeno doba, zbog izumiranja „živoga pamćenja“, postalo opsjednuto arhiviranjem, s tim da danas kao stvaratelj i održavatelj arhiva može funkcionirati bilo koji član neke zajednice, koliko god njegova pozicija u okviru šireg društvenoga konteksta možda bila beznačajna (isto: 30 - 33).

Iako ne zahvaća samo suvremene prilike, već širok luk od preko četiri stoljeća (17. st. - 21. st.), Šehovićevi Ilijasbegovići donose bogatu lepezu arhivara bošnjačkoga kismeta, koja obuhvaća kako pojedine članove obitelji Ilijasbegovića ( Hasan-beg, Sultanija, Enver-beg, Ilijas, Ilijasov rođak Rus, Enko...), tako i franjevce koji su stoljećima članove ove obitelji doživljavali kao „svoje“ (fra Matija, fra Ivan Lovrenović, fra Petar).

Ćitabhana, tj. knjižnica obiteljske kuće u Begovini u kojoj su se nalazili originalni Sultanijini zapisi otisnuti još na početku 18. stoljeća, kao i mnogi drugi zapisi o Ilijasbegovićima tijekom narednih stoljeća, postaje „mjesto pamćenja“ (Pierre Nora) za sve Ilijasbegoviće, ali i sve one koji s njima dijele sudbinu. To mjesto arhiv je niza „formativnih tekstova“ o Ilijasbegovićima/Bošnjacima - onih tekstova koji odgovaraju na pitanje „Tko smo mi'“, dakle služe samodefiniranju i osvjedočivanju o vlastitome identitetu (v. Assmann 2005: 166).

Element trajnosti pri tom je od iznimne važnosti za identitetska pitanja Bošnjaka. Spomenuta knjižnica u Begovini primjer je reprezentanta povijesnoga kontinuiteta

\footnotetext{
${ }^{204}$ U svojoj knjizi Kako se društva sjećaju (2004.) Paul Connerton povijesnoj rekonstrukciji prošlosti suprotstavlja koncept kolektivnoga ili društvenoga sjećanja, smatrajući da se ovakvo sjećanje ostvaruje putem dviju društvenih aktivnosti - komemorativnih ceremonija i tjelesnoga ponašanja (inkorporirane prakse i zapisani postupci).
} 
bošnjačkoga pitanja. Finitivna rečenica Ilijasbegovića, koju Enko kao posljednji Ilijasbegović izgovara fra Petru, referirajući se na davne zapise fra Matije o Ilijas-begu (17. st.), u tom kontekstu služi kao konstantna motivacija prilikom stoljetnih pokušaja pisanoga uobličavanja bošnjačkoga identiteta:,Neka se zna da nismo od jučer!“‘ (I: 1003)

Iako su izraz Bošnjaci, a posebno sintagma Bošnjaci-muslimani u Šehovićevu romanesknome ciklusu prvenstveno rezervirani za pripadnike obitelji Ilijasbegović ${ }^{205}$, kategoriji Bošnjak nerijetko se pridružuju likovi bosanskih franjevaca. Tako su, primjerice u Dubrovniku fra Matiju nazivali „šporkim Bošnjom“ (I: 51), a fra Ivan Lovrenović u svojim zapisima identificira se s položajem Bošnjaka: „Ljutila me ta nakaradna slika o mojim Bošnjacima...“(I: 432).

Ovakva povezanost likova kršćana i muslimana u Ilijasbegovićima, konkretizirana odnosom bosanskih begova i franjevaca, nastavlja se i u posljednjem Šehovićevu povijesnome romanu - Prokletoj ergeli (2009.).

Dok je u Ilijasbegovićima, bez obziru na analognost sudbina begova i franjevaca, naglasak ipak bio na bošnjačkom identitetu temeljenom na muslimanskoj vjeroispovijesti, u Prokletoj ergeli fokus je na likovima bosanskih franjevaca (fra Ilija, fra Andrija), a središnju identitetnu kategoriju u romanu predstavlja Bosanac.

Ni Prokleta ergela nije lišena iznošenja događaja pozicijom svjedoka (zapisi fra Andrije i fra Marka), kao ni para likova koji se temelje na binarnoj opoziciji kršćanstvo - islam, što je posebno vidljivo u drugome dijelu romana preko prijateljstva fra Andrije i Ali-age. Ova dva lika u zajedničkoj tamnici dijele sudbinu neosnovane optužbe, koja na metonimijskoj razini predstavlja sudbinu bosanskoga naroda.

Fra Andrija, kao i njegov prethodnik i uzor fra Ilija, u romanu imaju ulogu pregovarača s muslimanskim predstavnicima tijekom opsade Klisa (1596., 1648.). U tome je smislu zanimljivo pratiti dijaloške dijelove koji upućuju na „sadržaj“ kategorije Bosanac u kontekstu ovoga romana.

Prevodeći turski ultimatum o predaji branitelja kliške tvrđave, fra Ilija na kraju uočava potpis miralaja Fehima, prijatelja iz djetinjstva. Značajan je opis susreta dvojice predstavnika zaraćenih strana, kršćanina i muslimana, a koji se odigrao u nazočnosti predstavnika mletačke i turske vlasti. Za problematiku identitetnih predodžbi indikativna je rečenica koju pri susretu

\footnotetext{
${ }^{205}$ Npr. „Govorio je (...) da će Bošnjaci-muslimani, kako su Ilijasbegovići sebe oduvijek nazivali, doživjeti teška vremena." (I: 858)

Što se tiče nacionalne nominacije (Bošnjak/Bosanac), namjera ovoga rada nije baviti se njezinom problematikom. Rad je usmjeren na sadržajne sastavnice, odnosno identitetske oznake kategorije Bošnjak i Bosanac u kontekstu romanesknoga svijeta Feđe Šehovića.
} 
upućuje fra Ilija miralaju Fehimu nakon što mu je savjetovao da pred drugima moraju biti strogo službeni: „Što ćemo, kad nas Bosance nitko ne razumije!“ (PE: 37)

Ta rečenica ostvaruje ideju jedinstva u različitosti; na fokalizacijskoj razini likova Bosanac postaje kategorija koja sjedinjuje sve one koji su povezani s prostorom Bosne, bez obzira na vjeroispovijest.

Istovjetna se pregovaračka situacija u romanu odigrala pedesetak godina poslije Ilijinih pregovora, kad u pregovore s muslimanima odlazi fra Andrija. Iako, za razliku od fra Ilije, nije poznavao nikoga u turskome taboru, i ovaj je bosanski fratar primljen kao „zemljak“. Bimbaša Ali-aga, naime ističe kako mu je drago susresti se s „njegovim“ čovjekom, a fra Andrija, nakon što je primijetio da Turci ne vjeruju u pregovore s Mlečanima, naglašava kako je „njegov bosanski narod sklon maštovitom preuveličavanju“ (PE: 72). Iz opisanih epizoda pregovaranja vidljivo je kako je upravo kategorija Bosanac značajnija od bilo kojeg drugog oblika pripadnosti.

Osim toga, u svojim testimonijalnim zapisima fra Andrija koristi konstrukciju „ovaj naš bosanski narod“" (PE: 167), a njegov nasljednik fra Marko u svojim zapisima Ali-agu i fra Andriju prezentira kao „bosanske mučenike“(PE: 158).

Vidljivo je kako, umjesto na konfesionalnu suprotstavljenost likova, roman naglasak stavlja na Bosanca kao na kategoriju koja sjedinjuje, unificira. Time se problematika alteriteta $\mathrm{u}$ ovome romanu gradi u smjeru razlikovanja „onih iz Bosne“ od svih ostalih koji tu bosansku sudbinu ne dijele.

Dosadašnja razmatranja vode do zaključka kako u Ilijasbegovićima i Prokletoj ergeli Šehović koncept bošnjačkog i bosanskog kismeta temelji na motivu besmislene žrtvenosti i zajedničke patnje koja ciklički odjekuje stoljećima, a koja udružuje sve one čija je sudbina neodvojiva od sudbine Bosne, bez obzira na etničku i konfesionalnu pripadnost. Na vezivnu snagu prošlosti, posebno zajednički proživljene patnje, podsjeća Ernest Renan, francuski filozof kojega Aleida Assmann smatra važnim anticipatorom teorije o nacionalnome pamćenju budući da još u 19. stoljeću naglašava značaj odnosa prema prošlosti kao centralnog vezivnog tkiva nacionalne kohezije (2011: 47).

U svome eseju Što je nacija?(2007.) Renan napominje kako naciju ne određuje „rasa, jezik, materijalni interes, vjerski afinitet, geografija ni vojne potrebe“ (66). Za ovoga je filozofa nacija „duša, duhovni princip“ temeljen na zajedničkome posjedovanju bogatog nasljeđa sjećanja, posebno sjećanja na zajedničku patnju, uz želju za zajedničkim životom u budućnosti (66). 
„Što se nacionalnog pamćenja tiče, tuga je od veće vrijednosti nego trijumf, jer ona nameće dužnost i zahtijeva zajednički napor.

Nacija je, dakle, solidarnost na višoj razini, a čini ju osjećaj žrtve koju je čovjek podnio u prošlosti i one koje tek namjerava podnijeti u budućnosti. (...)

Velika skupina ljudi, zdrava uma i topla srca, stvara vrstu moralne svijesti koju zovemo nacija. Dokle god ta moralna svijest dokazuje svoju snagu žrtvama, koja iziskuje odricanje od pojedinačnog za napredak zajednice, ona je legitimna i ima pravo na postojanje.“ $(67)^{206}$

U kontekstu izgradnje kolektivnoga identiteta putem prezentacije zajedničke prošlosti, tj. onoga što se treba upamtiti, očuvati, Aleida Assmann (2011: 96) uočava da se u recentno vrijeme motivu patnje pridaje značajnija uloga u odnosu na ranija vremena; tema herojstva sve više ustupa mjesto temi patnje kao pozitivnoj kulturalnoj vrijednosti.

Ta je patnja u Šehovićevim romanima više vezana uz viktimološku nego sakrificijalnu dimenziju. Naime, svjedoci određenih događaja u pravilu nastoje potvrditi besmisao povijesnog žrtvovanja pojedinaca i kolektiva.

Izuzetak predstavljaju, kako je to ranije napomenuto, tek pojedini likovi: Enko u Ilijasbegovićima i manjim dijelom fra Marko u Prokletoj ergeli utjelovljuju predodžbu o mladim ljudima koji iz traumatične prošlosti mogu, barem u tragovima, izgraditi sliku neke drugačije budućnosti.

Svjedočenjem kao „ekstenzijom pamćenja, zahvaćenog u njegovoj narativnoj fazi“ (Ricoeur 2006: 802) posebice likovi begova (kao i njihovih nasljednika) i franjevaca u Ilijasbegovićima i Prokletoj ergeli formiraju autopredodžbe drugačijeg aksiološkoga predznaka u odnosu na predodžbe koje drugi konstruiraju o kategoriji bošnjačko/bosansko, ugrađujući (i) takve predodžbe u svoju kulturnu memoriju.

Njihovi su testimonijalni činovi, ovjekovječeni u nizu zapisa što opstaju u vremenu, mjesta konstruiranja mi-identiteta, odnosno kolektivnoga identiteta, onoga koji, kako to definira Jan

\footnotetext{
${ }^{206}$ Vidljivo je da Renanove postavke o naciji korespondiraju ideji nacije kao „zamišljene zajednice“ $u$ promišljanjima Benedicta Andersena (1990.). Riječ je o ,zamišljenoj“ zajednici u smislu stvaranja, a ne izmišljanja. Naime, ona je „zamišljena“ zato što „pripadnici čak i najmanje nacije nikad neće upoznati većinu drugih pripadnika svoje nacije, pa čak ni čuti o njima, no ipak u mislima svakog od njih živi slika njihovog zajedništva“"(17).
} 
Assmann, ,podrazumijeva sliku koju neka grupa gradi o sebi i s kojom se njezini članovi identificiraju“" (2005: 155).

U tom slučaju osjećaj zajedništva proizlazi iz zajedničkoga položaja, a razvija se na temelju kontrastivnoga ili antagonističkoga solidariziranja (mi prema oni) (isto: 157 - 158). Isticanje antagonističkoga principa, koji uspostavlja granicu mi-oni, sa sobom donosi i opasnost ksenofobičnoga odnosa prema drugome i drugačijemu - onome što se ne uklapa u određeni identitetni okvir. Stoga će naredno potpoglavlje ovoga rada, zahvaćanjem slike Bosne u Šehovićevim romanima, uključiti i problematiku suživota različitih.

\subsection{Književna predodžba Bosne}

Cilj je ovoga dijela rada propitati prezentaciju Bosne u povijesnim romanima Feđe Šehovića, imajući na umu kako „književne reprezentacije proizvode pseudogeografski imaginarij koji ima strukturne poveznice sa stvarnim svijetom“ (Syndram 2009: 79). Naravno, s obzirom da predodžbe o određenim geografskim prostorima u književnim djelima funkcioniraju prvenstveno u okvirima estetskoga konteksta djela, takve (re)prezentacije dopiru do čitatelja „kao skup 'kao da' konvencija, oslobađajući ih potrebe kritičkog preispitivanja, vjerodostojnosti i historičnosti“ (isto).

Uzevši figuru (ne)isključivosti kao referentnu točku, u Ilijasbegovićima i Prokletoj ergeli vidljivo je kolanje dviju proturječnih predodžbi o Bosni, iz čega je vidljiva nezaobilazna „,ambivalencija nacionalnih imagema“ (Leersen 2009: 109).

$\mathrm{Na}$ intrakulturnoj razini Bosna se u pojednim segmentima ovih romana oslikava kao prostor „,zaražen“" isključivošću, prvenstveno onom konfesionalnom.

Tako su određeni likovi Bošnjaka (npr. Ilijas-beg, Hasan-beg, Ilijas u Ilijasbegovićima, Aliaga u Prokletoj ergeli) neprihvaćeni od strane svojih Bošnjaka pod optužbom da surađuju s kršćanima kao s „onima drugima“. Istovjetna situacija vrijedi i za kršćansku stranu: likovima bosanskih franjevaca (npr. fra Matija i fra Ivan Lovrenović u Ilijasbegovićima, fra Ilija i fra Andrija u Prokletoj ergeli) vlastita franjevačka braća okreću leđa iz istih razloga.

Ovakva predodžba bosanskog prostora prvenstveno se slaže s književnom prezentacijom Dubrovnika u Šehovićevim romanima, kako u romanima dubrovačke trilogije, tako i u 
Ilijasbegovićima kao romanu čije se fabularne linije i grade na relaciji Bosna - Dubrovnik. To je prostor obilježen zatvorenošću, isključivošću prema svemu što predstavlja Drugog. Prezentacija gore navedenih likova Bošnjaka i bosanskih franjevaca, iz očišta onih likova koji su obilježeni isključivošću, može se iščitati putem Kristevina modela zazornosti, pri čemu se zazorno povezuje s pharmakosom ${ }^{207}$. Tako je svaki od ovih likova pretvoren u „biće zazornosti, u pharmakosa, krivca za tuđe grijehe“ (Kristeva 1989: 100).

Riječ je o likovima za koje vrijedi i analogija s onim likovima Ive Andrića koji su obilježeni ,pozicioniranjem između, u međuprostoru“ (v. Škvorc i Lujanović 2010), odnosno koji pripadaju nekom „trećem svijetu“, svijetu koji bi trebao predstavljati „,mostove između sukobljenih svjetova i posrednika u dijalogu civilizacija“ (Nemec 2003: 137). U Andrića se takva pozicija posebice prepoznaje u Travničkoj hronici na primjerima likova liječnika Davne, Cologne (Kolonje) ili Židova Atijasa.

Ipak, ključnu razliku između Andrićeva i Šehovićeva „trećega svijeta“ predstavlja činjenica da Andrićevi likovi ostaju usamljeni, izolirani u tom svijetu, oni sami za sebe jesu jedan „treći svijet“, dok Šehovićevi likovi funkcioniraju na razini parova likova „trećeg svijeta“ koji, iako utemeljeni na konfesionalnoj opreci (musliman - kršćanin), utjelovljuju ideju interkulturnoga dijaloga.

Parovi likova u Ilijasbegovićima (posebno Ilijas-beg - fra Matija, Ilijas-beg - fra Ivan Lovrenović i Enko - fra Petar) te Prokletoj ergeli (fra Andrija - Ali-aga) u okviru idejnoga sloja ovih romana kreiraju mogućnost suživota različitih na bosanskome prostoru, naglašavajući pri tome odgovornost pojedinca umjesto kolektivne odgovornosti. Naime, Šehovićevi romani svojim fabularnim okosnicama podcrtavaju stajalište teologa religije Dennisa Gire, koji tvrdi da se „dijalog uvijek odvija između osoba, ne između kršćanstva i ostalih religija, već između pripadnika tih religija, dakle između čovjeka i čovjeka“ (2008: 33). Očekivano načelo tolerancije postavlja se kao nedostatno budući da, kako Gira zaključuje, ,,istinski međureligijski dijalog treba ići 's onu stranu tolerancije"“ (isto: 18) i to „radi shvaćanja, učenja i razmjene“ (isto: 26).

U gore navedenim parovima likova zamjećuje se filija kao stav koji određuju odnos prema Drugome - filija je ,jedini slučaj stvarne, bilateralne razmjene“" s obzirom da podrazumijeva „uzajamno poštovanje i dvostruko priznato pozitivno vrednovanje“ (Pageaux 2009: 142 -

\footnotetext{
${ }^{207}$ Vidi prethodne dijelove ovoga rada koji se dotiču problematike patnje u Šehovićevim povijesnim romanima, a koja je neodvojiva od figure pharmakosa/žrtvenoga janjeta/položaja Joba.
} 
$143)^{208}$. Odnos prema Drugome zasnovan na filiji temelji se na predodžbi o Drugome kao o Drugome koji je pored Ja, ni superioran ni inferioran, već jednostavno prihvaćen kao Drugi (isto:143 - 144).

Uzevši u obzir razinu parova likova utemeljenih na svojevrsnoj dekonstrukciji binarne opozicije vlastito - strano / kršćanstvo - islam putem interkulturnoga dijaloga, može se zamijetiti i ukazivanje na dijaloški karakter identiteta svakoga od parnjaka. Charles Taylor, jedan od rijetkih teoretičara multikulturalizma koji se bavi pojedincem, a ne kolektivom, navodi da ,identitet pojedinca ima eminentno dijaloški karakter, drugim riječima, moje 'jastvo' (re)konstruira se putem kontakata i stalne razmjene s 'drugim' (v. Mesić 2006: 45). Šehovićevi likovi predstavnika begovske obitelji Ilijasbegovića, Ali-age (Prokleta ergela) te bosanskih franjevaca u oba romana demonstriraju dijaloški princip usađen u svaki od tih likova, kako prema drugome, tako i u odnosu na samoga sebe. Identitetni obrasci na tome se tragu ne vide kao ustaljene monolitne kategorije, već višeslojne i fluidne. Vidljiv je osjećaj „pripadnosti““ navedenih Šehovićevih likova različitim entitetima, gdje jedan ne ugrožava drugi. Stoga ovi likovi, kako sami za sebe, tako i u odnosu prema svojim parnjacima, kreiraju interkulturni dijalog kao princip na kojem se gradi jedna drugačija predodžba o Bosni.

Bosna kao interkulturni prostor gdje postoji sklad i suživot različitih, koji funkcioniraju kao jedan jedinstven narod u svojoj različitosti, posebice do izražaja dolazi putem zapisa likova-svjedoka koji cirkuliraju tijekom vremena, donoseći poklapanje „slike o Bosni“, što zorno prikazuju zapisi u Ilijasbegovićima, primjerice:

„Iz njegova teško razumljivoga rukopisa može se razabrati da se fra Matija umnogome slagao s tvrdnjama carigradskog knjižničara o nastajanju vjera na tlu zemlje Bosne, o jednom narodu i istom korijenu, krvi i jeziku.“(Ilijas-beg, kapetan trebinjski: 54)

„Hasan-beg je (...) počeo strasno govoriti o Bosni kako su o njoj mislili otac mu i fra Matija.“ (Inšallah: 233)

„Pri prvom susretu s njim (misli na fra Petra, op. D. M. L.) Enko je prepoznao pravog Bosanca, konačno se suočio u životu s nekim tako sličnim fra Matiji, prijatelju

\footnotetext{
${ }^{208}$ Imagolog Daniel-Henri Pageaux u svome radu „Od kulturnog imaginarija do imaginarnog“ (v. $2009: 125$ 150) izdvaja nekoliko temeljnih stavova koji određuju predodžbu o Drugome: maniju, fobiju, filiju i unifikaciju. Strana se kultura u okviru manije smatra superiornom, u okviru fobije inferiornom, dok filija strano promatra kao ravnopravno sebi. Unifikacija, težeći nekom novom skupu, dokida razlike između stranoga i svojega.
} 
njegovog prapradjeda iz 17. stoljeća. (...) Bosnu, koju voli, fra Petar vidi kao buket raznobojnog cvijeća. 'Jednobojno cvijeće ne miriše, nego zaudara', govorio je.“ (Od Mostara do Den Haaga: 964)

Istovjetne se književne slike o Bosni pronalaze i u Šehovićevu posljednjem povijesnome romanu Prokletoj ergeli. Iz zapisa fra Ilije, koji nastoji vrhuški u Rimu objasniti da „njegova Bosna nije ono što oni misle“(PE: 9), navodi se da

„(...) u Bosni živi bosanski narod s nekoliko vjera i isto toliko različitih korijena, zajedno jedni s drugima, u selima i gradovima, koji se međusobno poštuju, prijateljujući i pomažući jedni drugima“ (PE: 10).

I u ovome slučaju vidljiv je sukob heteropredodžbi i autopredodžbi: predožba o Bosni koju održava crkvena vlast u Rimu suprotstavljena je predodžbi bosanskoga franjevca. Iz očišta europskoga centra Bosna je, tragom orijentalističkoga diskursa Edwarda Saida, Orijent suprotstavljen Okcidentu u smislu odnosa moći (1999: 12), ona je stoga ,prostor koji treba kultivirati, obratiti i zaštititi“ (283) putem djelovanja stranih redovnika. Fra Ilijino protivljenje takvoj subalternoj slici Bosne Šehović dodatno gradi na uporabi ,jakog dokumenta“, što je rijedak primjer u romanima ovoga pisca. Naime, fra Ilija svoju predodžbu Bosne temelji na ispravi Mehmeda II. iz 1463. godine - ahdnami, koja bosanskim franjevcima i ostalim kršćanskim duhovnicima u Bosni jamči slobodu ispovijedanja vjere.

Stoljetna cirkulacija tekstova sa slikama o Bosni (posebice onih s testimonijalnom pozicijom) u oba Šehovićeva romana (Ilijasbegovići, Prokleta ergela) ukazuje na važnost intertekstualnosti i pri kreiranju predodžbi: uvijek je riječ o „uronjenosti“ u određeni kolektivni tekstualni imaginarij. Svaka predodžba o Bosni u Šehovićevim romanima, čak i kad nastoji aludirati na neku empirijski provjerljivu stvarnost/istinu, redovito ukazuje tek na svoju intertekstualnu ovjerenost.

Slika Bosne kao prostora svakodnevnoga življenja interkulturnoga dijaloga na fabularnom aspektu najviše dolazi do izražaja, kako je to ranije napomenuto, interakcijom protagonista koji pripadaju različitim konfesionalnim entitetima (posebice odnos likova begova i franjevaca). 
Posljednja slika Bosne, kojom Šehović zaokružuje svoju književnu problematizaciju ovoga pitanja u okvirima svojih povijesnih romana, nalazi se na samome kraju Proklete ergele (posredovano rukopisom mladoga fra Marka): izolirano planinsko mjesto, kreirano ozračjem arkadijske harmoničnosti, predstavlja sinegdohu Bosne ${ }^{209}$.

Fra Ilijin nasljednik fra Andrija, razočaran, ogorčen i otuđen (stalno svojstvo Šehovićevih protagonista), povlači se u planinsku kolibu Ali-aginih nasljednika:

„Fra Andriji su iz godine u godinu k Osman-aginoj kolibi u planini hodočastili brojni bolesnici, iz gradova i sela, podjednako muslimani i kršćani.“ (PE: 168)

„(Mucavi Ivan, op. D. M. L.) zaposlio je još dvojicu pastira, mlađih seljaka (jednog kršćanina i jednog muslimana, držeći se već pretjerano fra Andrijinih načela o poštovanju suživota vjera i naroda u Bosni!)“(PE: 170)

Iz dosad iznesene argumentacije vidljivo je kako se Šehović u kontekstu književnih predodžbi Bosne velikim dijelom postavlja u kontrastan odnos prema Ivi Andriću. Posebice je to vidljivo u Andrićevoj Travničkoj hronici, na koju se Šehovićeva saga o Ilijasbegovićima intertekstualno i referira u svome podnaslovu: Cronica travuniana.

Krešimir Nemec Travničku hroniku vidi kao „,narativnu razradu poetike nerazumijevanja“, gdje se Bosna konstruira kao „prostor napetosti u kojem se prezire Drugi i Drukčiji“, pa „svaku utopijsku projekciju i humanu gestu odmah guši surova realnost“" (2016: 243). Ideja interkulturnoga dijaloga, podsjeća Nemec, usađena je jedino u likove koji pripadaju tzv. hibridnim identitetima (242), odnosno nekom „trećem svijetu“, u koji se, kako jedan od njih, liječnik Kolonja, kaže, „sleglo sve prokletstvo usled podeljenosti zemlje na dva sveta“" (TH: 244) ${ }^{210}$.

Kod Šehovića se, kao ni kod Andrića, ideja kulturnoga dijaloga nikada ne ostvaruje na razini „velikih“ povijesnih aktera. Ipak, Šehović interkulturalnost, iz koje proizlazi mogućnost suživota različitih, realizira na razini odnosa onih „malih“, povijesno beznačajnih, onih čiji povijesni usud postaje golgota i gubitništvo. Interkulturalni karakter njihovih odnosa, kojima

\footnotetext{
${ }^{209}$ Vidi potpoglavlje ovoga rada „Društvena trauma i načelo ponavljanja“: Prostor „,proklete ergele“ na kliškoj tvrđavi u kontrastu je prema ovoj harmoničnoj slici suživota u Bosni budući da ,prokleta ergela“ funkcionira kao reprezentant svih područja na kojima se ne tolerira Drugi i Drugačiji.

${ }^{210}$ Prema: Andrić, Ivo. 2007. Travnička hronika. Sarajevo: Matica hrvatska u Sarajevu.
} 
se reflektira interkulturalnost Šehovićeve književne Bosne, iščitava se najvećim dijelom iz zapisa u kojima je naglašena njihova pozicija svjedoka.

U kontekstu etimoloških značajki termina ,interkulturalnost“ zanimljivo je uputiti na priklonjenost Zvonka Kovača (2001.) pristupu Eberharda Scheiffelea. Hermeneutičar Scheiffele (1988: 63) vidi ,inter“ $u$ interkulturnome dijalogu ne toliko kao uobičajeno „,između“, a time i kao granicu, već kao „zajedničku sredinu u kojoj svi sudjeluju tako što su solidarni na nju“, čime se prefiks ,inter“ više ne postavlja kao nešto ,između jednoga i drugoga“, već kao jedno $s$ drugim“ (istaknula D. M. L.).

Tako Šehovićeva književna Bosna, za razliku od Andrićeve, nije prezentirana kao multikulturalan prostor, ako se uzme da se multikulturalizam od strane nekih teoretičara promatra kao nešto statično, što potiče kulturnu zatvorenost (v. Mesić 2006).

Bosna se u Ilijasbegovićima i Prokletoj ergeli uglavnom prezentira konceptom interkulturalizma, koji „smjera otvorenim modelima kulture, poticanju njihovih kontakata i prožimanju (...) te za razliku od pomalo mehanicističkog značenja multikulturalizma, upućuje na stanovit dinamički, upravo dijaloški međuodnos“ (Mesić 2006: 68).

Ukratko bi se moglo podvući da je, na razini romanesknoga svijeta, Andrićevoj multikulturalnoj Bosni suprotstavljena Šehovićeva interkulturalna Bosna.

Slika Bosne (i) kao interkulturalnoga prostora prisutna je i u drugih književnika u okvirima bosanske književnosti. Tako u recentno vrijeme, primjerice, Jasmin Imamović u svome romanu Molim te, zapiši (2009.) ${ }^{211}$, također modelom svjedočenja protagonista, arkadijskim rječnikom ocrtava Bosnu: ,zemlja osunčana, suha, mirisna, zelena i slobodna“ (54). U tome tonu Imamovićeva je književna Bosna prikazana i kao „sklonište, ali i univerzitet slobodoumnih ljudi cijeloga svijeta“ (145), kao ne samo multikulturalno, nego i interkulturalno središte, točka na (pseudo)geografskoj karti svijeta gdje je moguć sretan suživot Jednih s Drugima.

U narednim bi istraživanjima bilo korisno predodžbe o Bosni i bosanskom/bošnjačkom identitetu u Šehovićevim povijesnim romanima dovesti u vezu s analognim temama u bošnjačkom/bosanskom (povijesnom) romanu.

Ne samo zbog biografskih odrednica, već i književnih imaginarija, nužno je i u slučaju Feđe Šehovića, kako to Zvonko Kovač (2001.) konstatira na primjerima određenih književnika (Ivo Andrić, Meša Selimović, Musa Ćazim Ćatić, Vladan Desnica...), uzeti u obzir višepripadnost,

\footnotetext{
${ }^{211}$ Zanimljivo je zamijetiti da je Imamovićev roman objavljen iste godine kad i Šehovićeva Prokleta ergela, a na koricama je podnaslovljen kao ,povijesni roman“.
} 
napustiti monocentrizam u književnoj historiografiji te aktualizirati tzv. poredbenu i/ili interkulturnu povijest književnosti. 


\section{ZAKLJUČAK}

Povijesni romani suvremenoga hrvatskog književnika Feđe Šehovića (1930.) tek su sporadično, a time i nedovoljno sustavno, zahvaćeni u hrvatskoj književnoj znanosti.

Prvenstveno svojim odnosom prema povijesti (povijest kao cikličnost, vraćanje istoga umjesto povijesti kao učiteljice života), ali i mnogim „gradbenim elementima“ (Matanović), Šehović se smješta u grupu onih autora hrvatskih povijesnih romana (Nedjeljko Fabrio, Ivan Aralica, Stjepan Tomaš, Ivan Supek, Ivica Ivanac, Ludwig Bauer...) koje obilježava odmak od tradicionalnoga povijesnog romana odnosno romana šenoinskoga tipa. Kod nekih je književnih znanstvenika (Milanja, Matanović) takva promjena paradigme obilježena terminološkom odrednicom hrvatski novopovijesni roman.

Vođena hipotezom kako se u okviru žanra hrvatskoga povijesnog romana akt svjedočenja može registrirati kao prepoznatljiva poetička oznaka opusa Feđe Šehovića, a time i njegovo analitičko-interpretacijsko polazište, disertacija je bila usmjerena upravo na problematizaciju svjedočenja u povijesnim romanima ovoga književnika.

Analiza je obuhvatila korpus onih Šehovićevih romana koji se u užemu smislu mogu podvući pod žanr povijesnoga romana: dubrovačku trilogiju pisanu pod pseudonimom Raul Mitrovich (Gorak okus duše, 1983; Oslobađanje đavola: Kronika, 1986; Uvod u tvrđavu: Biblija za nevjernike, 1989), petoknjižje Ilijasbegovići: Cronica travuniana iz 2002. godine (1. Ilijas-beg, kapetan trebinjski; 2. Inšallah; 3. Begovina; 4. Dubrovački intermezzo; 5. Od Mostara do Haaga) te Prokletu ergelu (2009.).

Koncept svjedočenja u navedenim povijesnim romanima Feđe Šehovića najvećim je dijelom razmotren na prepletu problematike tipologije i pozicije kako svjedoka tako i dokumenata, dok je u završnim poglavljima rada naglašena konstelacija svjedočenja i pamćenja/sjećanja (prezentacija traume svjedočenjem, svjedočenje u službi identitetnih predodžbi).

Pod utjecajem opaske Renate Jambrešić Kirin o distinkciji svjedočanstva i svjedočenja, u smislu razlikovanja historiografsko-dokumentarističkoga izvještaja od onog književnoga, u ovome se radu kontinuirano koristio potonji izraz - svjedočenje.

Iako temeljeno na narativnome modelu, svjedočenje je nesvodivo tek na problem pripovijedanja (Felman, Derrida), ono je neodvojivo od kategorija odgovornosti i obveze (Felman) te povjerenja (Derrida). Naime, svjedokov govor uvijek je apelativan, upućen je 
određenome adresatu, koji pak putem testimonijalnoga čina i sam postaje daljnji svjedok, čime se ostvaruje potencijalno beskonačan testimonijalni lanac.

U okviru teorije govornih činova (J. L. Austin) svjedočenje se otima ideji konstativa, u smislu utvrđivanja (ne)istinitosti testimonijalnoga iskaza. Uostalom, fokalizacija je svjedočenja apsolutno singularna (Derrida), a samim time objektivno neprovjerljiva. Svjedočenje funkcionira kao performativni čin - čin kojim se djeluje - pri čemu se svjedočenje gradi na interakciji svoje ekspozitivne i komisivne sastavnice.

Aktualnost testimonijalnosti u recentnim tekstovima, kako onih nefikcionalnoga, tako i onih fikcionalnoga predznaka, dovodi do sve češće uporabe sintagmi doba svjedoka (Wieviorka) / doba svjedočenja (Biti) pri pokušaju određivanja dominantnih značajki suvremenoga doba.

Može se zamijetiti da pri usporedbi s ostalim autorima hrvatskoga suvremenoga povijesnog romana, posebno uzevši u obzir načelo kontinuiranosti, Feđa Šehović naglašeno koristi koncept svjedočenja, zbog čega se testimonijalnost postavlja kao svojevrstan specificum njegova romanesknoga opusa.

Vidljivija zastupljenost mehanizma svjedočenja u suvremeno doba može se dovesti u vezu s drugačijim odnosom povijesti (u smislu historiografije), ali i povijesnih romana prema historiografskoj građi, a samim time i prošlosti općenito.

Težnja povijesnoj autentičnosti i mogućnosti verifikacije te sklonost „velikim“ dokumentima i „,velikim“ ličnostima službene povijesti zamijenjena je problematiziranjem statusa tekstualnih tragova prošlosti te aktualizacijom glasova onih koji predstavljaju ,,povijest odozdo“, prilikom čega je naglasak stavljen ne na povijesne podatke, nego na iskustvo same povijesti.

Iako se suvremeni hrvatski povijesni roman, gdje spadaju i oni Šehovićevi, nije poigravao poviješću onako kako su to činili strani autori postmodernističkih povijesnih romana, i u hrvatskoj književnosti ne može se ne registrirati drugačiji odnos prema povijesnome dokumentu kao dotad neupitnome autoritetu - taj odnos sad je zasnovan na preispitivanju i sumnji.

Protagonisti recentnih hrvatskih povijesnih romana uglavnom predstavljaju povijesno bezimene/beznačajne pojedince, one koji nisu akteri, već žrtve u zamasima povijesne vrtnje. Jedino privilegirano mjesto u govoru o povijesnom takvi pojedinci mogu ostvariti pozicijom svjedoka. Takva im pozicija omogućuje da pred svoj adresat, tj. zajednicu kojoj je upućen apel, posredstvom testimonijalnoga iskaza donesu (i) svoju (povijesnu) priču. 
Svjedočenje se u Šehovićevim romanima najčešće realizira konvencijom pronađenoga zapisa (rjeđe su u pitanju usmeni iskazi), odnosno svjedočenje o prošlome dano je u obliku tekstualiziranoga iskaza svjedoka događaja.

S obzirom na status figure svjedoka u narativu, može se zamijetiti da većina svjedoka ima ulogu likova, najčešće glavnih/protagonista (fra Vincenco i don Vicko u Gorkome okusu duše; Andro i Mavro u Oslobađanju đavola; Pepo i Luko u Uvodu u tvrđavu; fra Ilija i fra Andrija u Prokletoj ergeli; Ilijas-beg - Hasan-beg - Ilijas-beg - Ilijas - Enko u Ilijasbegovićima), ali i sporednih (npr. don Ivan u Gorkom okusu duše; diplomat Harden i nadbiskup Tores u Oslobađanju đavola; nepregledna galerija likova u Uvodu u tvrđavu; fra Marko u Prokletoj ergeli; fra Matija, Enes, Sultanija, fra Ivan Lovrenović...).

Uz dominaciju svjedoka-likova, u povijesnim romanima Feđe Šehovića našli su mjesto, mada zaista rijetko, i svjedoci koji nemaju status romanesknoga lika budući da ne sudjeluju u fabularnome tijeku.

U tome kontekstu prvenstveno treba istaknuti entitet fra Mavra S. u Gorkom okusu duše, koji u predgovoru romana nastupa kao pronalazač određenih rukopisa i kao ,autor“ romana o sudbini fra Vincenca i don Vicka (uvjetno gledajući, fra Mavro može funkcionirati kao lik ovog fikcionalnoga predgovora), kao i neke svjedoke dubrovačkoga potresa u Oslobađanju đavola (Nikša Bona, Francisco Paolo de Bobali). U Ilijasbegovićima (prvi roman ciklusa) takvu poziciju svjedoka zauzima tek kadija Ahmet-aga posredstvom svoje kronike o kriminalu.

Pripovjedna pozicija svjedočenja u Gorkome okusu duše, Oslobađanju đavola, Prokletoj ergeli te najvećem dijelu petoknjižja Ilijasbegovići, dakle većini Šehovićevih povijesnih romana, realizirana je situacijom pozivanja genettovskoga ekstradijegetičkogaheterodijegetičkoga pripovjedača na iskaze svjedoka (pisane i/ili usmene). Upravo ovakav tip pripovjedača predstavlja specifičnost i kod ostalih reprezentanata hrvatskoga suvremenoga povijesnog romana (npr. Aralica, Fabrio). Takav pripovjedač, iako postavljen izvan same fabule, nije povučen i nezamjetljiv, već u određenoj mjeri komentira fabularne elemente, najčešće na razini generalizacija i univerzalnih iskaza, čime se i hrvatski suvremeni povijesni romani nadovezuju na moralističan i poučan ton svojih prethodnika (tradicionalni povijesni roman šenoinskoga tipa).

Tek je u manjem broju Šehovićevih romana samome svjedoku dan pripovjedački status. Tako se u Uvodu u tvrđavu te dijelu Ilijasbegovića (od 32. poglavlja do kraja Begovine te čitav Dubrovački intermezzo) pojavljuju svjedoci kao homodijegetični pripovjedači. 
U Uvodu u tvrđavu svi svjedoci, koji su ujedno i likovi, zauzimaju takav položaj, dok se u dijelu Ilijasbegovića naratorskim glasom predstavlja Ilijas kao protagonist romana, nastojeći s razine svjedoka zahvatiti velike, prijelomne povijesne događaje.

Fokalizacijsko se pozicioniranje svjedoka (uzevši u obzir fokalizacijski model teoretičarke Mieke Bal) ostvaruje uglavnom posredstvom eksternoga fokalizatora (pogled izvana) koji na određenim mjestima, radi dojma autentičnosti i uvjerljivosti, ugrađuje u svoje fokalizacijsko motrište i pojedine fokalizacijske umetke svjedoka (Gorak okus duše, Oslobađanje đavola, Prokleta ergela, dio Ilijasbegovića).

Isključivo interna fokalizacija, u smislu iznošenja viđenja samo iznutra, podudara se s pozicijom svjedoka kao homodijegetičnoga pripovjedača. U tome je smislu vidljiva simbioza „pogleda“ i „glasa“ svjedoka u Uvodu u tvrđavu (svi likovi svjedoka) te dijelu Ilijasbegovića (Ilijas kao narator i fokalizator).

Bez obzira na vrstu fokalizacije (interna, eksterna), u Šehovićevim je romanima zamjetljivo i izmjenjivanje objekta i subjekta fokalizacije, a osim toga, uvijek je riječ o interpretirajućoj fokalizaciji.

Uzevši u obzir mimetičke moduse fikcionalne književnosti Northropa Fryea, Šehovićevi romaneskni svjedoci-protagonisti (fra Vincenco i don Vicko u Gorkom okusu duše; Andro i Mavro u Oslobađanju đavola; Pepo i Luko u Uvodu u tvrđavu; fra Ilija i fra Andrija u Prokletoj ergeli; Ilijas-beg - Hasan-beg - Ilijas-beg - Ilijas - Enko u Ilijasbegovićima) mogu se odrediti kao tragični jer riječ je o slučaju pojedinca izdvojenoga iz društva.

Uz to, figura patnje postavljena je kao njihovo provodno svojstvo. Budući da, u aksiološkome kontekstu, ti Šehovićevi likovi utjelovljuju pozitivne karakteristike (intelektualnost, dosljednost, požrtvovnost, empatičnost...), a osim toga obilježava ih i socijalno poželjna fizička karakterizacija, postavljanjem takvih likova u represivnu okolinu (pritvori, zatvori, logori) te izlaganjem psihofizičkim torturama na fabularnoj razini, proizvodi se efekt kontrasta između kvaliteta koje ti likovi utjelovljuju i sudbine koja im je namijenjena.

Figura patnje dodatno je podcrtana kontinuiranom uporabom martirološkoga leksika. Tako se o protagonistima-svjedocima najčešće govori kao o mučenicima, a o njihovu životnome putu kao o muci i golgoti, čime se konstruira prvenstveno kristološki model žrtvenosti, ali i model žrtvenosti općenito.

Ipak, valja istaknuti kako žrtvenost ovih likova nije visokomimetskoga modusa jer oni ne stradavaju zbog tragičke hamartie, poput grčkih junaka ili kršćanskih mučenika - njihova je 
žrtva tipična ili slučajna. Takvu vrstu žrtve N. Frye povezuje s arhetipskom figurom iz antičke književnosti pharmakos (žrtveno janje/žrtveni jarac), koja se pak može povezati i sa sudbinom starozavjetnoga Joba.

U tome smislu, kod Šehovića je zamjetljivo subverzivno iščitavanje jobovske sudbine, s tim da je analogija čovjek - Bog pomaknuta prema analogiji čovjek - ideologija. Naime, patnja nevinih, umjesto do učvršćenja vjere, dovodi do gubitka vjere i nade, do sumnje u sve moguće vrste ideoloških mehanizama, koji se, bez obzira na svoj predznak, uvijek prokazuju kao isključivi i pogubni za egzistenciju „,malog“ sudionika povijesti.

$\mathrm{Na}$ tragu prethodno rečenoga, uzevši u obzir tipologiju svjedoka Aleide Assmann, tek će jedan primjer protagonista (Enko na samom kraju Ilijasbegovića) jednim svojim dijelom predstavljati lik religijskoga svjedoka - žrtvenost će biti opravdana vjerom u nadmoćnu ideju (u Enkovu slučaju riječ je o vjeri u Bosnu). Međutim, i ovaj lik, kao i čitav niz Šehovićevih likova, kako primarnih tako i sekundarnih svjedoka, sudjeluje u izgradnji figure moralnoga svjedoka, onoga koji upućuje na negativne aspekte povijesti. Prilikom takvoga svjedočenja žrtvenost se ne postavlja kao uzvišen, već kao besmislen čin.

U kontekstu odnosa svjedoka-protagonista prema ideološkim strukturama kao problemske sastavnice obuhvaćene su ontemska figura (Peleš) (ne)vjerovanja te opreka sociema pisac - vlast.

U dubrovačkoj trilogiji figura (ne)vjerovanja u ideološke mehanizme realizirana je principom antonimskih parova likova, odnosno tzv. recipročnom karakterizacijom: fra Vincenco - don Vicko u Gorkome okusu duše, Andro - fra Mavro u Oslobađanju đavola, Luko - Pepu u Uvodu u tvrđavu.

Ilijasbegovići i Prokleta ergela, u tome kontekstu, dovode središnji lik u odnos prema većem broju likova (Ilijas prema članovima svoga rodoslovnoga stabla; fra Andrija prema fra Iliji, fra Marku i Ali-agi).

Ako se izuzme broj i širina analogijskih odnosa, može se uočiti korespondentan karakterizacijski model u svim povijesnim romanima Feđe Šehovića. Naime, bez obzira na početni stupanj ideološkoga vjerovanja, manjim ili većim pomacima u okviru karakterizacijskoga procesa, svi svjedoci-protagonisti dovedeni su do pozicije ideološkoga nevjernika. Uostalom, figura (ne)vjerovanja funkcionira kao krovna odrednica ontemske dimenzije Šehovićevih romana.

Potonja se problematika izravno nadovezuje (i) na sociemski (Peleš) sukob pisac vlast. 
Na različite načine Šehovićevi su likovi duboko uronjeni u svijet literature. Oni su studenti i profesori književnosti, samostanski prepisivači i knjižničari, u svakodnevnome životu „prepoznaju“ mjesta literature, o literarnim se pitanjima raspravlja i u logorskim kaznionicama...

Pri tome su najznačajniji oni likovi koje obilježava status pjesnika (don Vicko, fra Mavro, Pepo), ali i pisaca općenito (npr. Luko, fra Ilija, fra Andrija, fra Ivan Lovrenović...), budući da njihovo djelovanje unutar romanesknoga svijeta postaje poligon za propitivanje poetičkih pitanja (književnoga) stvaralaštva, ali i društvenog aspekta pisanja (posebice recepcijski obzori).

U odnosu pisac - vlast unutar Šehovićevih povijesnih romana do izražaja dolaze epizode ideološki (ne)opravdanih kaznenih progona, onih koji su reakcija ne samo na poetsko djelovanje u užem smislu, već i na bilo kakvo djelovanje riječima koje nije usklađeno s koordinatama vladajuće ideologije. A potreba za svjedočenjem, pak kod tih likova podudara se s potrebom da se, bez obzira na rizik, autentično progovori o proživljenome, o utiskivanju povijesnoga na osobne živote, na vlastita tijela.

U tome se smislu svaki testimonijalni čin u Šehovićevim povijesnim romanima može sagledati kao parezijski čin (Foucault) - hrabrost istine, u vidu njezina svjedočenja bez obzira na društvene posljedice.

Dužnost svjedočenja posebno je ugrađena u likove pisaca, koji su ne samo vlastitim iskustvom (kao primarni svjedoci), već i kao adresati svjedočenja drugih, umjetnički i intelektualno odgovorni na sebe preuzeti ulogu sekundarnoga/intelektualnoga svjedoka (Hartman). Iz toga kuta, svrha svjedočenja proizlazi i iz stapanja performativne prirode samoga čina svjedočenja s kategorijama etičkoga.

Pozicija je svjedoka u Šehovićevim povijesnim romanima toliko naglašena da su dokumenti u okviru romana odraz govora svjedoka, zbog čega ih se može okarakterizirati kao testimonijalne dokumente.

Sam dokument u suvremenome hrvatskom povijesnom romanu poprima mnogo širi dijapazon značenja u odnosu na šenoinski roman, što je, između ostaloga, odraz i drugačijeg odnosa prema dokumentu, a time i samom historiografskome sloju romana.

Težnja korespondentnosti historiografskoga sloja sa službenom verzijom povijesti, a time i objektivnosti, zamijenjena je načelom relativizacije te subjektivnošću. Potonji se pristup u Šehovićevu primjeru očituje prvenstveno u izboru same vrste dokumenata, kao i njihovim pozicioniranjem unutar romaneskne strukture. 
Imperativ zapisivanja kao topos Šehovićevih romana uklapa se u ideju nužno tekstualizirane dostupnosti prošlosti (Hutcheon), a uglavnom je ostvaren motivom pronađenih i/ili sačuvanih zapisa. Dok konvencija pronađenih rukopisa više dolazi do izražaja u romanima dubrovačke trilogije (Gorak okus duše, Oslobađanje đavola, Uvod u tvrđavu), koji svoje naslove i duguju naslovima stanovitih pjesničkih rukopisa, u romanima nastalima u ovome stoljeću (Ilijasbegovići, Prokleta ergela) pozornost je usmjerena na sam čin zapisivanja te čuvanja zapisa za budućnost.

Prilikom diskurzivne klasifikacije (testimonijalnih) dokumenata u Šehovićevim povijesnim romanima, uočava se njihova raznolikost: kronike, dnevnički fragmenti, epistolarni zapisi, autobiografija u užem smislu, testimonijalna (logorska) literatura, esejističke bilješke, pjesnički tekstovi, usmeni iskazi te slikovni zapisi.

Od posebnog su značaja franjevačke kronike, kojima, poput primjerice i Ivana Aralice, Šehović ulazi u krug pisaca andrićevske tradicije. Šehovićeve su kronike pak, suprotno očekivanim žanrovskim odrednicama, potpuno intimizirane, riječ je o kronikama biografskoga karaktera, u kojima kroničar kao sekundarni svjedok iznosi kroniku muke svoga bližnjega, najčešće brata franjevca (npr. fra Andrijina kronika o fra Iliji ili fra Markova kronika o fra Andriji u Prokletoj ergeli) ili prijatelja koji predstavlja vjeroispovijesnoga Drugoga (npr. fra Matijina kronika o kapetanu Ilijas-begu ili kronika fra Ivana Lovrenovića o Ilijas-begu u Ilijasbegovićima).

Zapravo, sve su vrste dokumenata, s obzirom da polaze od percepcije malog čovjeka kao svjedoka događaja, izrazito subjektivizirane. Osim toga, nije riječ o dokumentima čija se ovjera može pronaći u arhivima empirijske zbilje, kakav je slučaj bio sa Šenoinim predgovornim pozivanjem na dokumentarnu građu. $\mathrm{U}$ tome su kontekstu dokumenti u Šehovićevim romanima istodobno primjeri tzv. slabih dokumenata, ali i paracitatnih tekstova.

Poput ostalih predstavnika suvremenoga hrvatskoga povijesnog romana (Fabrio, Aralica, Tomaš, Bauer...), na dokumentarističku se građu Šehović najčešće (unutar svih svojih romana) poziva u okviru osnovnoga teksta (katkad izravnim citiranjem zapisa svjedoka, katkad neupravnim govorom).

U većini romana prisutne su, više ili manje frekventno, i fusnote kao paratekstualni prostor (Genette) u kojem se navode informacije vezane uz dokumentarističku građu (naziv dokumenta, autor, vrijeme nastanka, sadržajne i stilske sastavnice i sl.), dok je predgovorna bilješka kao mjesto upućivanja na konzultirane zapise ostvarena samo u Gorkome okusu duše (predgovor fra Mavra S.). 
Ipak, usprkos uvriježenoj kategorizaciji fusnota i predgovora kao paratekstualnih tvorbi, u smislu njihove graničnosti s obzirom na svijet teksta / svijet izvan teksta, Šehovićevi primjeri fusnota i predgovora isključivo su fiktivne prirode, bez relacije s tzv. izvantekstualnom zbiljom - i fusnote i predgovor svoje uporište grade u okviru samoga svijeta romana.

U Uvodu u tvrđavu izbjegnute su sve gore navedene situacije inkorporacije dokumenata budući da taj roman u cijelosti predstavlja zbir dokumenata, bez posredničke instance, slijedom čega se na recepcijskoj razini proizvodi efekt zapisa koji „sami govore“.

Zapravo, Šehovićevi romani svojim odnosom prema dokumentu u potpunosti se odmiču od uopćene analogije zbilja - tekst i fokusiraju na odnos među tekstovima, upućujući time i na pretpostavku kako je prošla zbilja uvijek tekstualno proizvedena.

Na tom tragu svi testimonijalni dokumenti u analiziranim Šehovićevim povijesnim romanima ponašaju se prvenstveno kao tekstovi - demonstriraju svoju intertekstualnost kao opće obilježje svakoga teksta, kako na unutartekstualnoj razini (među dokumentima unutar pojedinih romana) tako i na razini odnosa dokumenata romana s tekstovima hrvatske i svjetske književne baštine.

$\mathrm{S}$ uporištem u testimonijalnome diskursu, govor o (povijesnom) traumatskome $\mathrm{u}$ Šehovićevim povijesnim romanima odmiče se od sfere pisanja o traumi (pokušaj objektivne rekonstrukcije prošlih zbivanja) prema pisanju same traume (LaCapra). Pisanje traume pisanje je posttraumatskoga, zahvaćenoga kako procesom odjelotvorenja, tako i prorade.

U svjetlu mimetičkoga/antimimetičkoga modela reakcije na traumatsko (Ruth Leys), Šehović svojim romanima upućuje na njihovu neisključivost i koegzistenciju.

$\mathrm{Na}$ individualnoj razini, tj. na razini karakterizacije likova svjedoka, činom svjedočenja omogućava se pokušaj narativizacije traumatskoga, a time i terapijski učinak. Na ovaj se način svjedočenje okreće pokušaju proradbe, pronalazeći time svoje mjesto u okvirima antimimetičke reakcije na traumatsko.

Koncept povijesti u Šehovićevim romanima, posebno preko temporalne dimenzije, korespondira pak s neizbježnim mimetičkim licem traumatskoga, onim koje uključuje tek mogućnost beskonačnog odjelotvorenja. Povijest predočena kao cikličnost, repetitivnost, nosi obilježje traumatskoga koda: nema izlaza iz prošlosti jer se ukida distinkcija prošlosti, sadašnjosti i budućnosti, prošlo postaje i sadašnje i buduće.

Repetitivnost traume / povijesti kao traume povezana je i s kategorijama prešućivanja i skrivanja, slijedom čega testimonijalni čin kao oblik revizije službene verzije povijesnih događaja može u sebi sadržavati potencijal ,,izlaska“ iz traumatskoga. 
Fraktalnost se traume (A. St. Just) kao specifična vrsta ponavljanja (svaki dio reflektira cjelinu i obratno) uočava prilikom premještanja traume s individualne, mikrorazine, na onu društvenu, pa i povijesnu u najširem smislu. Tako se, primjerice, jobovska sudbina pojedinih likova svjedoka u Ilijasbegovićima zrcali kako u sudbini obitelji Ilijasbegović, tako i u sudbini cjelokupne bošnjačke zajednice - i obratno.

Testimonijalni zapisi unutar romana objavljenih u ovome stoljeću (Ilijasbegovići, Prokleta ergela), posebice franjevačke kronike i esejistički zapisi likova begova i franjevaca, uključuju se u sferu kulturnoga pamćenja i sjećanja propitivanjem tekstualne proizvodnje kolektivnih identitetnih predodžbi.

Interaktivnim odnosom autopredodžbi i heteropredodžbi, u čijoj se kreaciji može registrirati konfesionalna opozicioniranost (kršćanstvo - islam), balkanistički diskurs (Todorova) te koncept zazornosti (Kristeva), grade se identitetni modeli Bošnjaka (Ilijasbegovići) i Bosanca (Prokleta ergela).

Dok heteropredodžbe (vizura „,velike“ Europe) prvenstveno podrazumijevaju subalternu sliku bošnjačkoga/bosanskoga, autopredodžbe (vizura likova franjevaca i begova) podcrtavaju žrtveni identitetni model Bošnjak/Bosanac, i to ne u sakrificijalnoj nego u viktimološkoj dimenziji žrtvenosti. Pri tome upravo motiv zajednički proživljene patnje, koja se zajednici nastoji prezentirati testimonijalnim aktom, djeluje kao kohezivni element (Renan) prilikom formiranja kolektivnoga ili mi-identiteta (Assmann), usprkos etničkoj i konfesionalnoj različitosti.

Testimonijalni zapisi svojim intertekstualnim ulančavanjem tijekom vremena formiraju kontinuitet misli o bošnjačkome/bosanskome identitetu, kao i o slici Bosne u navedenim romanima. Šehovićeva književna Bosna izrasta na značajkama interkulturalizma, čime u književnome imaginariju zauzima znatno drugačiji položaj od Andrićeve multikulturalne Bosne.

Daljnji bi književnoznanstveni interes valjalo usmjeriti kako na cjelovitije zahvaćanje Feđe Šehovića u okvirima hrvatske književne znanosti proširenjem testimonijalne problematike i na romane koji se u užem smislu odmiču od žanra povijesnoga romana, tako i na interkulturno/poredbeno pozicioniranje (hrvatska - bosanska književnost) ovoga suvremenoga književnika. 


\section{LITERATURA}

\section{Izvori}

Šehović, Feđa. 1996. Gorak okus duše. Zagreb: Školska knjiga.

Šehović, Feđa. 1986. Oslobađanje đavola. Zagreb: Grafički zavod Hrvatske.

Šehović, Feđa. 1989. Uvod u tvrđavu. Zagreb: Grafički zavod Hrvatske.

Šehović, Feđa. 2006. Ilijasbegovići. Zagreb: Profil international.

Šehović, Feđa. 2009. Prokleta ergela. Zagreb: V. B. Z.

Alighieri, Dante. 2004. Božanstvena komedija. Preveli Mihovil Kombol i Mate Maras. Zagreb: Globus media.

Andrić, Ivo. 2007. Travnička hronika. Priredio Ivan Lovrenović. Sarajevo: Matica hrvatska u Sarajevu / FMC Svjetlo riječi d.o.o. Sarajevo.

Andrić, Ivo. 2014. Prokleta avlija. Podgorica: Nova knjiga.

Aralica, Ivan. 2004. Psi u trgovištu. Zagreb: Večernji list.

Baudelaire, Charles. 1996. Cvjetovi zla Spleen Pariza. Preveli Ante Jurević i ostali. Predgovor i izbor Višnja Machiedo. Zagreb: SysPrint.

Bauer, Ludwig. 2001. Kratka kronika porodice Weber. Zagreb: Mozaik knjiga.

Cihlar Nehajev, Milutin. 1963. Vuci. U: Bijeg /Vuci, PSHK, knj. 2, uredio Jakša Ravlić. Zagreb: Matica hrvatska; Zora.

Crijević, Ilija. 1969. Oda Dubrovniku. U: Hrvatski latinisti, PSHK, knj. 2., uredili V. Gortan i V. Vratović. Zagreb: Matica hrvatska.

Čehov Pavlovič, Anton. 1960. Drama bez naslova / Pisma. U: Sabrana djela (knjiga X.). 
Preveli Borislav Mrkšić, Božidar Škritek i Maja Mulić. Zagreb: Zora.

Držić, Leo. 1994. Magarcima pucaju rebra. Zagreb: Durieux.

Fabrio, Nedjeljko. 1990. Berenikina kosa. Zagreb: Znanje.

Fabrio, Nedjeljko. 2002. Triemeron. Zagreb: Nakladni zavod Matice hrvatske.

Fabrio, Nedjeljko. 2005. Vježbanje života. Zagreb: Profil international.

Imamović, Jasmin. 2009. Molim te, zapiši. Zagreb: V. B. Z.

Ivanac, Ivica. 1990. U službi Josipa baruna Jelačića. Zagreb: Mladost.

Katušić, Ivan. 1987. Admiralski stijeg. Zagreb: Znanje.

Pavličić, Pavao. 2004. Koraljna vrata. Zagreb: Večenji list.

Supek, Ivan. 1995. Buna Janusa Pannoniusa. U: Izabrana djela / Ivan Supek, PSHK, priredio Branko Hećimović,161 - 435. Zagreb: Matica hrvatska.

Šenoa, August. 1963. Seljačka buna. U: Sabrana djela (knjiga IV.), priredio Slavko Ježić. Zagreb: Znanje.

Šenoa, August. 1991. Seljačka buna. Priredila Ljerka Car-Matutinović. Zagreb: Školska knjiga.

Šenoa, August. 1995. Čuvaj se senjske ruke. Priredio Dubravko Jelčić. Zagreb: Školska knjiga.

Šenoa, August. 2004. Zlatarovo zlato. Zagreb: Večernji list.

Tomaš, Stjepan. 1993. Zlatousti. Zagreb: Znanje. 


\section{Predmetna literatura}

Agamben, Giorgio. 2004. Ideja proze. Preveo i pogovor napisao Ivan Molek. Zagreb: AGM. Agamben, Giorgio. 2008. Ono što ostaje od Auschwitza: Arhiv i svjedok (homo sacer III). Preveo Mario Kopić. Zagreb: Antibarbarus.

Ančić, Nedjeljko Ante. 1982. Prijepor i svjedočenje vjere. Crkva u svijetu, vol. 17, br. 3: 232 239.

Aristotel. 2005. O pjesničkom umijeću. Preveo i uredio Zdeslav Dukat. Zagreb: Školska knjiga.

Assmann, Aleida. 2011. Duga senka prošlosti: Kultura sećanja i politika povesti. Prevela Drinka Gojković. Beograd: Biblioteka XX vek.

Assmann, Jan. 2005. Kulturno pamćenje: Pismo, sjećanje i politički identitet u ranim visokim kulturama. Preveo Vahidin Preljević. Zenica: Vrijeme.

Austin, John Langshaw. 2014. Kako djelovati riječima. Prevela Andrea Milanko. Zagreb: Disput.

Badurina, Natka. 2010. Vrijeme traume, vrijeme svjedočenja. Testimonijalna literatura i književni kanon tijekom dvadesetog stoljeća. U: Komparativna povijest hrvatske književnosti. Zbornik radova XII. Istodobnost raznodobnog. Tekst i povijesni ritmovi, uredili C. Pavlović i ostali, 189 - 210. Split - Zagreb: Književni krug; Odsjek za komparativnu književnost Filozofskog fakulteta Sveučilišta u Zagrebu.

Bahtin, Mihail. 2000. Problemi poetike Dostojevskog. Prevela Milica Nikolić. Beograd: Čigoja štampa.

Bal, Mieke. 2000. Naratologija: Teorija priče i pripovedanja. Prevela Rastislava Mirković. Beograd: Narodna knjiga, Alfa. 
Barthes, Roland. 1992. Uvod u strukturalnu analizu pripovjednih tekstova. U: Suvremena teorija pripovijedanja, priredio Vladimir Biti, 47 - 78, prevela Dubravka Celebrini. Zagreb: Globus.

Barthes, Roland. 1999a. Smrt autora. U: Suvremene književne teorije, priredio Miroslav Beker, 197 - 201. Zagreb: Matica hrvatska.

Barthes, Roland. 1999b. Od djela do teksta. U: Suvremene književne teorije, priredio Miroslav Beker, 202 - 207. Zagreb: Matica hrvatska.

Begović Sokolija, Ena. 2017. Predodžbe o franjevcima u savremenoj bošnjačkoj književnosti. U: Književnost kao prostor izazova u reprezentaciji/konstrukciji bošnjačkog kulturnog identiteta. Zbornik radova s Naučnoga skupa u Brčkom održana 15. - 16. 10. 2016. 59 - 74. Brčko: Bošnjačka zajednica kulture.

Begović, Sead. 2008. Književni portreti - Feđa Šehović. Behar, 17 (85): 14 - 38. http://www.scribd.com/doc/23193398/Behar-br-85 (12. 10. 2012.).

Bekavac, Luka. 2015. Prema singularnosti: Derrida i književni tekst. Zagreb: Disput.

Belaj, Melanija. 2008. Obiteljska fotografija kao kreiranje i arhiviranje (poželjne) stvarnosti. Narodna umjetnost, 45/2: 135 - 151.

Beljan, Iva. 2011. Pripovijedanje povijesti: Ljetopisi bosanskih franjevaca iz 18. stoljeća. Zagreb - Sarajevo: Synopsis.

Benčić, Živa. 2006. Lica Mnemozine: Ogledi o pamćenju. Zagreb: Naklada Ljevak.

Biti, Vladimir. 2000a. Pojmovnik suvremene književne i kulturne teorije. Zagreb: Matica hrvatska.

Biti, Vladimir. 2000b. Strano tijelo pri/povijesti. Zagreb: Hrvatska sveučilišna naklada. Biti, Vladimir. 2002. Performativni obrat teorije pripovijedanja. U: Politika i etika pripovijedanja, uredio Vladimir Biti, 7 - 31. Zagreb: Hrvatska sveučilišna naklada.

Biti, Vladimir. 2005. Doba svjedočenja: Tvorba identiteta u suvremenoj hrvatskoj prozi. Zagreb: Matica hrvatska. 
Bošković, Ivan. 1984. Roman gubitka ili scenarij traganja za dnom ljudske sudbine (Raul Mitrovich, Gorak okus duše - roman, Grafički zavod Hrvatske, 1983. godine). Mogućnosti, 10 - 11: 926 - 932.

Bošković, Ivan. 2009. Držić u Šehovićevu djelu ili Držić u Šehoviću čitan. U: Komparativna povijest hrvatske književnosti. Zbornik radova XI. Držić danas. Epoha i naslijeđe. 367 - 380. Split: Književni krug.

Brkljačić, Maja i Prlenda, Sandra. 2006. Kultura pamćenja i historija. Zagreb: Golden marketing - Tehnička knjiga.

Brnčić, Jadranka. 2014. Foucault o pareziji i parezija u kršćanstvu. Holon, 4 (2): 181 219.

Buljubašić, Ivana. 2017. Pojam parateksta Gérarda Genettea u okviru suvremene naratologije. Anafora, IV (1): 15 - 35.

Caruth, Cathy. 1996. Unclaimed experience: Trauma, Narrative and History. Baltimore and London: The John Hopkins University Press.

Chatman, Seymor. 1983. Karakter u pripovjednom tekstu. Preveo Vladimir Biti. Republika, br. 10: $112-139$.

Connerton, Paul. 2004. Kako se društva sjećaju. Prijevod Zdravko Židovec. Zagreb: Izdanja Antibarbarus.

Culler, Jonathan. 2009. Teorija književnosti (Sasvim kratak uvod). Preveo Dragan Ilić. Beograd: Službeni glasnik.

Derrida, Jacques. 2000. A Self-Unsealing Poetic Text: Poetics and Politics of Witnessing. Translated by Rachel Bowlby. http://ark.cdlib.org/ark:/13030/kt309nc6gn/ (2.8.2018.) 
van Dijk, Teun A. 2006. Ideologija: multidisciplinaran pristup. Preveo Živan Filippi. Zagreb: Golden marketing - Tehnička knjiga.

Dukić, Davor. 2009. Predgovor: O imagologiji. U: Kako vidimo strane zemlje (Uvod u imagologiju), 5 - 22. Zagreb: Srednja Europa.

Duvnjak Radić, Žaklina. 2011. Autobiografija, fikcija i ja. Beograd: Službeni glasnik.

Englesko-hrvatski rječnik. 1999. Uredili Rudolf Filipović i ostali. Zagreb: Školska knjiga.

Fališevac, Dunja. 2008. Renesansna poslanica kao prostor poetičko-estetičkih iskaza. Colloquia Maruliana, XVII. (17): 7 - 25.

Fališevac, Dunja. 2011. Kako Držića pamte suvremeni hrvatski pisci. U: Dani hvarskoga kazališta: Pamćenje, sjećanje, zaborav u hrvatskoj književnosti i kazalištu. Zagreb Split: Hrvatska akademija znanosti i umjetnosti; Književni krug Split.

Felman, Shoshana. 1992a. The Return of the Voice: Claude Lanzmann's Shoah. U:

Testimony: Crises of witnessing in literature, psychoanalysis and history, 204 - 283.

New York and London: Routledge.

Felman, Shoshana. 1992b. Education and Crisis, or the Vicissitudes of Teaching. U:

Testimony: Crises of witnessing in literature, psychoanalysis and history, 1 - 56. New York and London: Routledge.

Felman, Shoshana. 2007. Pravno nesvjesno: Suđenja i traume u dvadesetom stoljeću. Prevela Marina Miladinov. Zagreb: Deltakont.

Fischer, Manfred S. 2009. Komparatistička imagologija: za interdisciplinarno istraživanje nacionalno-imagotipskih sustava. U: Kako vidimo strane zemlje (Uvod u imagologiju), uredio Davor Dukić, 37 - 56. Zagreb: Srednja Europa.

Foucault, Michel. O drugim prostorima: http://pescanik.net/o-drugim-prostorima/ (22. 3. 2018.).

Foucault, Michel. 2015a. Hrabrost istine: Vladanje sobom i drugima II. (Predavanja na College de France 1983. - 1984.). Preveo Zlatko Wurzberg. Zagreb: Sandorf i Mizantrop. 
Foucault, Michel. 2015b. Što je autor? (Izlaganje). Prevela Nataša Medved. Zagreb: Naklada Jesenski i Turk.

Franić, Anet. 2010. Feđa Šehović: Antologije sastavljaju neuspješni kazališni pisci, Slobodna Dalmacija (22. 9. 2010.)

http://www.slobodnadalmacija.hr/scena/kultura/clanak/id/112029/fedja-sehovicantologije-sastavljaju-neuspjeli-kazalisni-pisci (12. 11. 2013.)

Freud, Sigmund. 1986. Budućnost jedne iluzije i drugi spisi. Izabrao Gvozden Flego. Preveo Boris Buden. Zagreb: Naprijed.

Fried, Istvan. 2006. Imagološka pitanja. U: Kulturni stereotipi: Koncepti identiteta u srednjoeuropskim književnostima, uredili D. Oraić Tolić i E. Kulcsar Szabo, 71 - 80. Zagreb: FF press.

Frye, Northrop. 2000. Anatomija kritike (Četiri eseja). Prevela Giga Gračan. Zagreb: Golden marketing.

Genette, Gérard. 1992. Tipovi fokalizacije i nihova postojanost. U: Suvremena teorija pripovijedanja, priredio Vladimir Biti, 96 - 115, prevela Dubravka Celebrini. Zagreb: Globus.

Genette, Gérard. 1997. Palimpsest: Literature in the Second Degree. Translated by Channa Newman and Claude Doubinsky. Foreword by Gerarld Prince. Lincoln and London: Univerity of Nebraska Press.

Gira, Dennis. 2008. S onu stranu tolerancije: Susret religija. Preveo Ivan Nujić. Zagreb: A.G.M.

Glavina, Vesna. 2016. Tvrđava Klis: Priča o uskocima i Petru Kružiću. Zagreb: Školska knjiga.

Grdešić, Maša. 2015. Uvod u naratologiju. Zagreb: Leykam international.

Gross, Mirjana. 2001. Suvremena historiografija. Zagreb: Zavod za hrvatsku povijest Filozofskog fakulteta Sveučilišta u Zagrebu; Novi Liber. 
Hartman, Geoffrey. 2006. Shoah and Intellectual Witness. Reading on Library, 4. http://readingon.library.emory.edu/issue1/articles/Hartman/RO\%20-\%202006\%20\%20Hartman.pdf. (11. 10. 2018.).

Herman, Judith Lewis. 1996. Trauma i oporavak: Struktura traumatskog doživljaja. Prevela Radmila Zdjelar. Zagreb: Ženska infoteka.

Hutcheon, Linda. 1988. A poetics of postmodernism. History, theory, fiction. New York, London: Routledge.

Ivić, Nenad. 1992. Domišljanje prošlosti (Kako je trinaestostoljetni splitski arhiđakon Toma napravio svoju salonitansku historiju). Zagreb: Zavod za znanost o književnosti Filozofskoga fakulteta.

Jambrešić Kirin, Renata. 1999. Svjedočenja o Domovinskom ratu i izbjeglištvu: Književnoteorijski i kulturnoantropološki aspekti. Doktorska disertacija. Filozofski fakultet Sveučilišta u Zagrebu.

Jambrešić Kirin, Renata. 2005. Tko svjedoči za svjedoka? 15 dana, br. 1: 34 - 41.

Jelčić, Dubravko. 2004. Povijest hrvatske književnosti. Zagreb: Naklada Pavičić.

Jouve, Vincent. 2000. Složenost lik-efekta. U: Autor, pripovjedač, lik, priredio Cvjetko Milanja, 479 - 573, prevela Sanja Šoštarić. Osijek: Svjetla grada; Sveučilište Josipa Jurja Strossmayera; Pedagoški fakultet.

Jukić, Tatjana. 2003. Priče iz davnine: Hrvatska historiografska metafikcija. U: Prošla sadašnjost: Znakovi povijesti u Hrvatskoj, uredili Vladimir Biti i Nenad Ivić, 128 157. Zagreb: Naklada MD.

Jürgensen, Manfred. 1991. Dnevnik: Uvod. Gordogan, br. 31 - 32 - 33: 231 - 247.

Kazaz, Enver. 2015. Treći svijet i njegova mudrost isključenosti. U: Ivo Andrić - svugdašnji. 
Zbornik radova s Međunarodnoga znanstvenog skupa održana 25. studenoga 2005. u Zagrebu, 51 - 57. Zagreb: Hrvatsko kulturno društvo Napredak.

Klaić, Bratoljub. 2007. Rječnik stranih riječi. Zagreb: Školska knjiga.

Kovač, Zvonko. 2001. Poredbena i/ili interkulturna povijest književnosti. Zagreb: Hrvatsko filološko društvo.

Kristeva, Julia. 1984. Revolution in Poetic Language. Translated by Margaret Waller. New York: Columbia University Press.

Kristeva, Julia. 1989. Moći užasa (ogled o zazornosti). Prevela Divina Marion. Zagreb: Naprijed.

Kuljić, Todor. 2006. Kultura sećanja (teorijska objašnjenja upotrebe prošlosti). Beograd: Čigoja štampa.

Kundera, Milan. 2002. Umjetnost romana. Prevela Vanda Mikšić Zagreb: Meandar.

Kusijanović, Stanislava. 1977. Stil i svijet književnog djela Feđe Šehovića. Magistarski rad. Centar za Postdiplomski studij Dubrovnik.

LaCapra, Dominick. 2011. Writing history, writing trauma. Baltimore and London: The John Hopkins University Press.

Lachmann, Renate. 1988. Intertekstualnost kao konstitucija smisla. U: Intertekstualnost $i$ intermedijalnost, uredili Zvonko Maković i dr., 75 - 108. Zagreb: Zavod za znanost o književnosti.

Lachmann, Renate. 2002. Phantasia/Memoria/Rhetorica. Izabrao i preveo Davor Beganović. Priredio Vladimir Biti. Zagreb: Matica hrvatska.

Laub, Dori. 1992. Bearing Witness, or the Vicissitudes of Listening. U: Testimony: Crises of witnessing in literature, psychoanalysis and history, 57 - 74. New York and London: Routledge. 
Laub, Dori. 1995. Truth and Testimony: The Process and the Struggle. U: Trauma:

Explorations in Memory, edited, with introductions, by Cathy Caruth, 61 - 75.

Baltimore and London: The John Hopkins University Press.

Leerssen, Joep. 2009. Retorika nacionalnoga karaktera: programatski pregled. U: Kako vidimo strane zemlje (Uvod u imagologiju), uredio Davor Dukić, 99 - 124. Zagreb: Srednja Europa.

Lejeune, Philippe. 2000. Autobiografski sporazum. U: Autor, pripovjedač, lik, priredio Cvjetko Milanja, 201 - 236, prevela Lada Čale Feldman. Osijek: Svjetla grada; Sveučilište Josipa Jurja Strossmayera; Pedagoški fakultet.

Levi, Primo. 2017. Zar je to čovjek. Preveo Tvrtko Klarić. Zaprešić: Fraktura.

Lodge, David. 1988. Načini modernog pisanja. Prevele Giga Gračan i Sonja Bašić. Zagreb: Globus - Stvarnost.

Lovrenović, Ivan. 2005. Duh iz sindžira: eseji, članci, polemike (1973 - 2004). Zagreb: Durieux.

Lukács, György. 1986. Roman i povijesna zbilja. Priredili Hotimir Burger i Vjekoslav Mikecin. Zagreb: Globus.

Lukšić, Irena. 1996. Gorak okus duše Feđe Šehovića (pogovor). U: Šehović, Feđa, Gorak okus duše, 157 - 172. Zagreb: Školska knjiga.

Matanović, Julijana. 1995. Hrvatski novopovijesni roman: Prijedlog definicije. Republika, br. 9 - 10: $98-114$.

Matanović, Julijana. 1998. Povijesni roman u hrvatskoj književnosti XX. stoljeća. Doktorska disertacija. Filozofski fakultet Sveučilišta u Zagrebu. Matanović, Julijana. 2003. Krsto i Lucijan: Rasprave i eseji o povijesnom romanu. Zagreb: Naklada Ljevak. 
McHale, Brian. 1987. Postmodernist fiction. London and New York: Routledge.

Mesić, Milan. 2006. Multikulturalizam. Zagreb: Školska knjiga.

Mijatović, Aleksandar. 2009. Trauma i pitanje reprezentacije: suvremena teorija traume, Sigmund Freud i Walter Benjamin. Fluminensia, god. 21, br. 2: 143 - 162.

Milanja, Cvjetko. 1994. Hrvatski novopovijesni roman. Ulomak iz veće cjeline. Kolo, br. 11 12: 1077 - 1098.

Milanja, Cvjetko. 2006. Arabeska kodova. U: Aralica u očima književne kritike, priredila H. Mihanović-Salopek, 240 - 297.

Nemec, Krešimir. 1992. Prvi hrvatski povijesni roman. Mogućnosti, god. 39, br. 5 - 6 - 7: 531 $-537$.

Nemec, Krešimir. 2003. Povijest hrvatskog romana: od 1945. do 2000. Zagreb: Školska knjiga.

Nemec, Krešimir. 2016. Gospodar priče: Poetika Ive Andrića. Školska knjiga: Zagreb.

Nietzsche, Friedrich. 2004. O korisnosti i štetnosti historije za život. Priredio i preveo Damir Barbarić. Zagreb: Matica hrvatska.

Novak, Slobodan Prosperov. 2004. Povijest hrvatske književnosti. Svezak III. Split: Marjan tisak.

Oblučar, Branislav. 2014. „Kondicionalna istina“ - esej kao književni žanr. Umjetnost riječi, god. LVIII, br. 1: 75 - 90 .

Oraić Tolić, Dubravka. 1990. Teorija citatnosti. Zagreb: Grafički zavod Hrvatske.

Oraić Tolić, Dubravka. 1993. Autoreferencijalnost kao metatekst i kao ontotekst. U: Intertekstualnost i autoreferencijalnost, uredili Dubravka Oraić Tolić i Viktor Žmegač, 135 - 147. Zagreb: Zavod za znanost o književnosti Filozofskoga fakulteta Sveučilišta u Zagrebu.

Oraić Tolić, Dubravka. 2006. Hrvatski kulturni stereotipi: Diseminacija nacije. U: Kulturni 
stereotipi: Koncepti identiteta u srednjoeuropskim književnostima, uredili Dubravka Oraić Tolić i Erno Kulcsar Szabo, 29 - 45. Zagreb: FF press.

Oraić Tolić, Dubravka. 2011. Akademsko pismo: Strategije i tehnike klasične retorike za suvremene studentice i studente. Zagreb: Naklada Ljevak.

Pageaux, Daniel-Henri. 2009. Od kulturnog imaginarija do imaginarnog. U: Kako vidimo strane zemlje (Uvod u imagologiju), uredio Davor Dukić, prevela Sanja Šoštarić, 125 - 150. Zagreb: Srednja Europa.

Paljetak, Luko. 2010. Prožetost moralnošću i eksplicitno zalaganje za slobodu i suživot. Behar, god. XIX/XX, br. 98: 59.

Pavličić, Pavao. 1995. Pismo Madoni Markantunovoj. U: Rukoljub: Pisma slavnim ženama, 117 - 130. Zagreb: Slon.

Peleš, Gajo. 1999. Tumačenje romana. Zagreb: ArTresor naklada.

Peternai, Kristina. 2005. Učinci književnosti: Performativna koncepcija pripovjednog teksta. Zagreb: Disput.

Ravlić, Slaven. 2001. Politička ideologija: preispitivanje pojma. Politička misao, vol XXXVIII, br. 4: 146 - 160.

Renan, Ernest. 2007. Što je nacija? Priredio Tvrtko Lovreković. Pro tempore: časopis studenata povijesti, god. IV, br. 4: 61 - 67.

Ricoeur, Paul. 1990. Preplitanje historije i fikcije. Preveo Mladen Kožul. Quorum, br. 4: 236 247.

Ricoeur, Paul. 2006. Pamćenje, povijest, zaborav. Europski glasnik, god. XI, br. 11: 799 807.

Rimmon-Kenan, Shlomith. 1989. Naracija: razina i glasovi. U: Uvod u naratologiju, uredio i preveo Zlatko Kramarić, 81 - 103. Osijek: Izdavački centar Revija; 
Radničko sveučilište Božidar Maslarić.

Said, Edward W. 1999. Orijentalizam. Prevela Biljana Romić. Zagreb: Konzor.

Sablić Tomić, Helena. 2002. Intimno i javno: suvremena hrvatska autobiografska proza. Zagreb: Naklada Ljevak.

Sablić Tomić, Helena. 2008. Hrvatska autobiografska proza: rasprave, predavanja, interpretacije. Zagreb: Naklada Ljevak.

Semprun, Jorge. 1996. Pisanje ili život. Prevele Jasna Stojanović i Ivana Stojanović. Beograd: Paideia.

Sertić, Mira. 1970. Stilske osobine hrvatskog historijskog romana. U: Hrvatska književnost prema evropskim književnostima, 175 - 255. Zagreb: Mladost.

Slabinac, Gordana. 2006. Sugovor s literarnim đavlom: eseji o čitateljskoj nesanici. Zagreb: Naklada Ljevak.

Solar, Milivoj. 1976. Teorija književnosti. Zagreb: Školska knjiga.

Solar, Milivoj. 2006. Rječnik književnog nazivlja. Zagreb: Golden marketing - Tehnička knjiga.

Sontag, Susan. 2007. O fotografiji. Prevela Ivana Rončević. Osijek: Naklada EOS.

St. Just, Anngwyn. 2012. Trauma: time, space and fractals. Poland: Amazon Fulfillment.

Stanzel, Franz. 1992. Pripovjedni tekst u prvom i pripovjedni tekst u trećem licu. U:

Suvremena teorija pripovijedanja, priredio Vladimir Biti, prevela Srebrenka Iveković, 178 - 200. Zagreb: Globus.

Subašić Thomas, Sunita. 2014. Epistemološka revolucija književnosti svjedočenja.

Sarajevske sveske, br. 43 - 44.

http: //sveske.ba/en/content/epistemoloska-revolucija-knjizevnosti-svjedocenja 
(13. 11. 2018.).

Syndram, Karl Ulrich. 2009. Estetika alteriteta: Književnost i imagološki pristup. U: Kako vidimo strane zemlje (Uvod u imagologiju), uredio Davor Dukić, prijevod Z. Blažević, 71 - 81. Zagreb: Srednja Europa.

Šarić, Ljiljana i Wittschen, Wiebke. 2010. Rječnik sinonima hrvatskoga jezika. Zagreb: Naklada Jesenski i Turk.

Šehović, Feđa. https://www.jutarnji.hr/arhiva/feda-sehovic-ilijasbegovici/3221459/ (17. 3. 2018.).

Šicel, Miroslav. 1997. Hrvatska književnost 19. i 20 stoljeća. Zagreb: Školska knjiga.

Šimić, Krešimir. 2009. Protestiram, dakle jesam. Vijenac, 412. www.matica.hr/vijenac/412/protestiram-dakle.jesam-2638/ (20. 9. 2018.)

Škvorc, Boris i Lujanović, Nebojša. 2010. Andrić kao model izmještenog pisca ili kako je otvoren prostor za 'pozicioniranje između' nacionalnoga korpusa i kulturalnih paradigmi. Fluminensia, god. 22, br. 2: 37 - 52.

Šporer, David. 2010. Status autora: Od pojave tiska do nastanka autorskih prava. Zagreb: AGM.

Scheiffele, Eberhard. 1988. Razlikovanje i afinitet: Problem pretpostavki interkulturnog razumevanja. Kultura, Beograd, br. 82 - 83: 54 - 69.

http://casopiskultura.rs/MagazinePublication/ShowPublicationPdf?magazinePublicatio $\underline{\text { nId }=2103}(3.11 .2012$.)

Todorova, Marija. 1999. Imaginarni Balkan. Prevele Dragana Starčević i Aleksandra Bajazetov-Vučen. Beograd: Biblioteka XX vek.

Vaglio, Luca. 2015. Andrićev ciklus o fra Petru. U: Ivo Andrić - svugdašnji; zbornik radova s Međunarodnog znanstvenog skupa održana 25. studenoga 2005. u Zagrebu, 69 - 84. 
Zagreb: Hrvatsko kulturno društvo Napredak.

Velčić, Mirna. 1991. Otisak priče: Intertekstualno proučavanje autobiografije. Zagreb: August Cesarec.

Vugdelija, Marijan. 1994. Job i problem patnje. Bogoslovska smotra, br. 3: 219 - 248.

White, Hayden.1987. The Content of the Form: Narrative Discourse and Historical Representation. https://www.scribd.com/document/95638012/Hayden-White-The-Content-of-theForm-1987 (21. 9. 2018.).

White, Hayden. 2004. Historijska pripovjednost i problem istine u historijskom prikazivanju. Preveo Višeslav Aralica. Časopis za suvremenu povijest, XXXVI, br. 2: 621 - 635.

Wilde, Oscar. 2009. Ocvat laganja (Opservacija - Dijalog). U: Intencije, 7 - 44, preveo Damjan Lalović. Zagreb: Disput.

Zima, Zdravko. 1989. Rastrgana paučina snova (pogovor). U: Šehović, Feđa, Uvod u tvrđavu: Biblija za nevjernike. Zagreb: Grafički zavod Hrvatske.

Zlatar, Andrea. 1998. Autobiografija u Hrvatskoj: Nacrt povijesti žanra i tipologija narativnih oblika. Zagreb: Matica hrvatska.

Zlatar, Andrea. 2000. Ispovijest i životopis: Srednjovjekovna autobiografija - rasprava. Zagreb: Izdanja Antibarbarus.

Zlatar, Andrea. 2004. Književnost svjedočenja. U: Tekst, tijelo, trauma: Ogledi o suvremenoj ženskoj književnosti, 163 - 184. Zagreb: Naklada Ljevak.

Žmegač, Viktor. 1994. Povijesni roman danas. U: Književnost i filozofija povijesti, 65 - 88. Zagreb: Hrvatsko filozofsko društvo. 


\section{ŽIVOTOPIS}

Dijana Mikšić Labura (1981., Šibenik) diplomirala je 2007. godine na Odsjeku za hrvatski jezik i književnost (jednopredmetni studij) Sveučilišta u Zadru obranivši diplomski rad „Tematizacija vlasti u romanu Ivana Aralice Psi u trgovištu“ pod mentorstvom prof. dr. sc. Zvjezdane Rados. Sa zvanjem profesorice hrvatskoga jezika i književnosti radi kao nastavnica i učiteljica hrvatskoga jezika u šibenskoj srednjoj i osnovnoj školi.

U listopadu 2010. godine upisala je Poslijediplomski doktorski studij književnosti, izvedbenih umjetnosti, filma i kulture na Filozofskome fakultetu Sveučilišta u Zagrebu (mentorstvo dr. sc. Julijane Matanović, izv. prof.).

\section{Sudjelovanje na znanstvenim skupovima}

Konteksti: prvi međunarodni interdisciplinarni skup mladih naučnika društvenih i humanističkih nauka, 1. prosinca 2012., Novi Sad, Srbija: „Interkulturni dijalog kao tematsko-idejni sloj Šehovićeva romana Prokleta ergela“ (usmeno izlaganje)

Zadarski filološki dani 5: međunarodni znanstveni skup, 27. i 28. rujna 2013., Zadar, Hrvatska: „Predodžbe o domaćem i stranom u Krležinu romanu Povratak Filipa Latinovicza“ (usmeno izlaganje)

Sarajevski filološki susreti 3: međunarodna naučna konferencija, 29. i 30. svibnja 2014., Sarajevo, Bosna i Hercegovina: „Konvencija pronađenoga zapisa u romanu Feđe Šehovića/Raula Mitrovicha Uvod u tvrđavu: Biblija za nevjernike“" (usmeno izlaganje) Sarajevski filološki susreti 4: međunarodna naučna konferencija, 22. - 24. rujna 2016., Sarajevo, Bosna i Hercegovina: „Status autora u Dubrovačkoj trilogiji Feđe Šehovića“ (usmeno izlaganje)

Sarajevski filološki susreti 5: međunarodna naučna konferencija, 20. - 22. rujna 2018., Sarajevo, Bosna i Hercegovina: „Slika Bosne i Bošnjaka u segmentu romanesknoga ciklusa Feđe Šehovića Ilijasbegovići: Cronica travuniana“ (usmeno izlaganje) 


\section{Objavljeni radovi}

Mikšić, Dijana. 2012. Lik slikara u Krležinu romanu „Povratak Filipa Latinovicza“ i

Fabrijevu romanu „Triemeron“: odnos umjetnika prema povijesnome i nacionalnome. Fluminensia: časopis za filološka istraživanja, god. 24, br. 2: 33 - 44.

Mikšić, Dijana. 2012. Domobran Jambrek: figurativnost u službi antiratne poruke. Hrvatski: časopis za teoriju i praksu nastave hrvatskoga jezika, književnosti, govornoga $i$ pismenoga izražavanja te medijske kulture, god. 10, br. 2: 9 - 21.

Mikšić, Dijana. 2013. „Gorak okus duše“ Feđe Šehovića: funkcija pjesničke zbirke iz romana u kontekstu intertekstualnih relacija. Jat: časopis studenata kroatistike, god. 1, br. 1: $196-206$.

Mikšić, Dijana. 2014. Žanrovske igre u Fuentesovoj „Diani ili boginji koja lovi sama“. Književna smotra: časopis za svjetsku književnost, god. XLVI, br. 174 (4): 97 - 101.

Mikšić, Dijana. 2014. Interkulturni dijalog kao tematsko-idejni sloj Šehovićeva romana „Prokleta ergela“. Konteksti: zbornik radova s Prvog međunarodnog interdisciplinarnoga skupa mladih naučnika društvenih i humanističkih nauka održanoga u Novome Sadu 1. 12. 2012. Novi Sad: Filozofski fakultet Univerziteta u Novom Sadu. 411 - 420.

Mikšić Labura, Dijana. 2015. Predodžbe o domaćem i stranom u Krležinu romanu „Povratak Filipa Latinovicza“. Zbornik radova s Međunarodnoga znanstvenog skupa Zadarski filološki dani 5 održanog u Zadru 27. i 28. rujna 2013. Zadar: Sveučilište u Zadru. $15-25$.

Mikšić Labura, Dijana. 2018. Status autora u Dubrovačkoj trilogiji Feđe Šehovića. Sarajevski filološki susreti 4: Zbornik radova (knjiga 2). Sarajevo: Bosansko filološko društvo. $216-226$. 